\title{
ESTUDOS EM CIÊNCIAS HUMANAS E SOCIAIS
}

\section{VOLUME 1}

ORGANIZADOR

ANDERSON LINCOLN VITAL DA SILVA
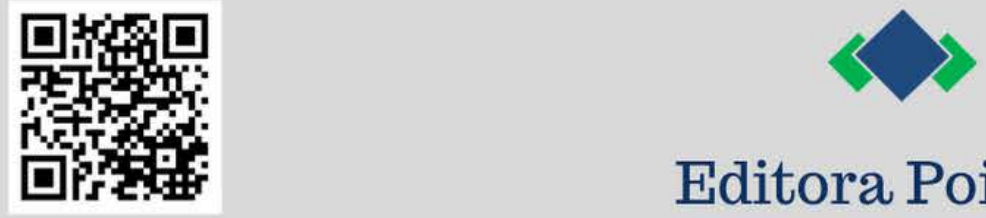

Editora Poisson 
Anderson Lincoln Vital da Silva

(Organizador)

\section{Estudos em Ciências Humanas e Sociais Volume 1}

1ạ Edição

Belo Horizonte

Poisson

2021 
Editor Chefe: Dr. Darly Fernando Andrade

\section{Conselho Editorial}

Dr. Antônio Artur de Souza - Universidade Federal de Minas Gerais

Msc. Davilson Eduardo Andrade

Dra. Elizângela de Jesus Oliveira - Universidade Federal do Amazonas

Msc. Fabiane dos Santos

Dr. José Eduardo Ferreira Lopes - Universidade Federal de Uberlândia

Dr. Otaviano Francisco Neves - Pontifícia Universidade Católica de Minas Gerais

Dr. Luiz Cláudio de Lima - Universidade FUMEC

Dr. Nelson Ferreira Filho - Faculdades Kennedy

Msc. Valdiney Alves de Oliveira - Universidade Federal de Uberlândia

Dados Internacionais de Catalogação na Publicação (CIP)

E82 Estudos em Ciências Humanas e Sociais - Volume 1/
Organização: Anderson Lincoln Vital da Silva - Belo
Horizonte - MG: Poisson, 2021
Formato: PDF
ISBN: 978-65-5866-091-0
DOI: 10.36229/978-65-5866-091-0
Modo de acesso: World Wide Web
Inclui bibliografia
1.Ciências Sociais 2. Sociedade 3. Ciências
Humanas 4. Direito I. SILVA, Anderson Lincoln Vital
da II.Título

O conteúdo dos artigos e seus dados em sua forma, correção e confiabilidade são de responsabilidade exclusiva dos seus respectivos autores.

Baixe outros títulos gratuitamente em www.poisson.com.br contato@poisson.com.br 


\section{Sumário}

Capítulo 1: Home office: Um modal a se explorar na administração pública 06 Estefano Batista Silva

DOI: 10.36229/978-65-5866-091-0.CAP.01

Capítulo 2: Como é a percepção de um programa de voluntariado no meio universitário? 17

Beatriz Naemi Genovez Aoki, Christiano França da Cunha

DOI: 10.36229/978-65-5866-091-0.CAP.02

Capítulo 3: Educação Social - Pedagogia Social: Origem, conceito e contradições com a Pedagogia Escolar 30

Micheline Medeiros dos Santos Sant'Anna, Beatriz Rosália Gomes Xavier Flandoli

DOI: 10.36229/978-65-5866-091-0.CAP.03

Capítulo 4: Justiça social e globalização - Uma crítica das Cidades Inteligentes à luz da paridade participativa de Nancy Fraser 39

Rodolfo Aparecido Leite, Vitor Augusto de Carvalho Lins

DOI: 10.36229/978-65-5866-091-0.CAP.04

Capítulo 5: Assentamento São Bento em Heitoraí-Go: Uma leitura do espaço cotidiano e da (re)produção das relações sociais de produção 46 Jean Carlos Ribeiro de Lima, Mary Anne Vieira Silva DOI: 10.36229/978-65-5866-091-0.CAP.05

Capítulo 6: Neoliberalismo, Território e a Região Metropolitana de Manaus - Nos entremeios de uma "região incomum" e o comum como princípio da geopolítica da metropolização 53

Susane Patrícia Melo de Lima

DOI: 10.36229/978-65-5866-091-0.CAP.06

Capítulo 7: Estado e Marxismo: Uma (re)leitura em tempos de "crise". 69

Márcia da Silva Pereira Castro, Izabella Patrícia Brito da Silva

DOI: 10.36229/978-65-5866-091-0.CAP.07

Capítulo 8: Racismo: Sob a ótica social contemporânea no Brasil

Boniek Pereira da Silva, Monik Pereira da Silva, Antônio Vagner Almeida Olavo, Andres Juan Pablo Silva Sanchez, Antônio Henrique Queiroz Conceição

DOI: 10.36229/978-65-5866-091-0.CAP.08 


\section{Sumário}

Capítulo 9: Possibilidade de concessão do salário-maternidade à parentalidade homoafetiva na gestação substitutiva. 87

Camila Fenalti Salla, Andrea Nárriman Cezne, Mariana Fenalti Salla

DOI: 10.36229/978-65-5866-091-0.CAP.09

Capítulo 10: Os Conceitos de Discurso e Ação em Arendt para justificar vivências de criação na área da Assistência Social 93

Zenilda Batista Bruginski

DOI: 10.36229/978-65-5866-091-0.CAP.10

Capítulo 11: Elementos sociais, culturais e econômicos da adolescência no Espectro do Autismo . 98

Amanda Pereira Risso Saad, Paulo Roberto Haidamus de Oliveira Bastos, Geisa Alessandra Cavalcante de Souza

DOI: $10.36229 / 978-65-5866-091-0 . C A P .11$

Capítulo 12: Direito internacional dos direitos humanos, crise econômica e migrações de venezuelanos para Roraima 106

Marcos Joel de Melo Santos

DOI: $10.36229 / 978-65-5866-091-0 . C A P .12$

Capítulo 13: Presunção de inocência versus liberdade de imprensa e seus reflexos na instituição do Júri.

Camila Fenalti Salla

DOI: $10.36229 / 978-65-5866-091-0 . C A P .13$

Capítulo 14: Conflito e Paixão: Três momentos da história em que o futebol foi mais que um jogo 123

David de Brito Alvarenga, João Paulo Ferreira, Samuel de Gois Vida

DOI: 10.36229/978-65-5866-091-0.CAP.14

Autores: 


\section{Capítulo 1}

Home office: Um modal a se explorar na administração pública

\section{Estefano Batista Silva}

Resumo: Este artigo tem como objetivo capturar a percepção dos funcionários públicos do estado da Bahia, do setor administrativo, por meio de pesquisa de opinião, que trabalharam no regime home office total ou parcial no quesito eficiência e a eficácia de seus serviços, no período da pandemia da Covid-19. Para isso utilizou a estratégia metodológica quantitativa, descrição estatística com base na pesquisa de opinião realizada por meio de pesquisa survey. Diante disso foi capturado como resposta pelos servidores que o modelo home office exerce impacto positivo sobre a eficiência e eficácia do serviço público, bem como a manifestação da preferência pela modalidade parcial a total.

Palavra-chave: Administração Pública. Home Oficce. 


\section{INTRODUÇÃO}

Diante o período da pandemia, declarada pela Organização Mundial de Saúde (Worl Health Organization) [OMS] (2020), em 11 de março de 2020, causada pela Covid-19, resultado da proliferação mundial do novo coronavírus (Sars-Cov-2), uma das providências adotadas pelas instituições públicas à sociedade foi a imposição do isolamento social, o que gerou, por consequência, a possibilidade do trabalho remoto aos servidores públicos estaduais do setor administrativo.

Nesta perspectiva, o Governo do Estado da Bahia, através do decreto № 19.528 de 16 de março de 2020, instituiu o trabalho remoto no poder executivo estadual por meio do artigo segundo, considerado como trabalho prestado remotamente por servidor público ocupante de cargo efetivo ou em comissão, com a utilização de recursos tecnológicos, fora das dependências físicas do órgão ou da entidade de sua lotação, e cuja atividade, não constituindo por sua natureza trabalho externo, possa ter seus resultados efetivamente mensuráveis, com efeitos jurídicos equiparados àqueles da atuação presencial (Casa Civil, 2020).

Diante desse cenário as instituições públicas adotaram a modalidade de home office total ou parcial. A primeira, as atividades dos servidores são realizadas totalmente em suas casas, com seus recursos e a segunda, é caracterizada por trabalho alternado, um dia home office e outro presencial (no local de trabalho), adotada para reduzir a quantidade de pessoas no mesmo local. Assim, fica a pergunta que caracteriza o problema deste artigo, a aplicação da modalidade home office interfere na eficiência e eficácia das atividades da Administração Pública, de acordo com a ótica dos servidores públicos da Bahia, Brasil, no período de pandemia da Covid-19, nos meses de abril e maio de 2020?

A adoção da modalidade home office no setor administrativo da Administração Pública ficou a critério dos dirigentes ou chefes de cada órgão/setor, que deve analisar o tipo de serviço desenvolvido pela unidade, se é possível e exequível ser adotado teletrabalho total ou parcial, assim como a faixa etária e o estado de saúde dos funcionários, tendo em vista que a covid-19 acomete com maior índice de letalidade pessoas idosas ou com quadro prévio de doenças, de modo que estes indivíduos passaram a ser considerados grupo de risco (OMS, 2020).

Este artigo tem o objetivo de capturar a percepção dos funcionários públicos do estado da Bahia, do setor administrativo, por meio de pesquisa de opinião, que trabalharam no regime home office total ou parcial no quesito eficiência e a eficácia de seus serviços, no período da pandemia da Covid-19, mais precisamente nos meses de abril e maio de 2020.

Este artigo tem como direcionamento de público a comunidade acadêmica e os gestores da Administração Pública que possuam interesse no tema.

Esta pesquisa foi realizada por meio do método indutivo, em conglomerado de evidências teóricas. Pra melhor compreensão do tema o modelo teórico é composto pelo recorte conceitual de tecnologia, eficiência e eficácia no serviço público. E para obter resposta a perguntar levantada neste texto foi montado um banco de dados com formato longitudinal para dar suporte ao modelo estatístico multivariável.

Este artigo está estruturado em cinco partes, em que a primeira é representada por esta introdução, a segunda pela fundamentação teórica, a terceira consiste na metodologia, a quarta refere-se à análise dos resultados e a última parte à nas considerações finais.

\section{FUNDAMENTAÇÃO TEÓRICO}

A revolução tecnológica foi uma das grandes responsáveis pela transformação recente da forma de trabalho. Dentre as principais ferramentas amplamente utilizadas neste processo estão a internet e a conexão em rede, intra-organização e entre as organizações, em diferentes escalas territoriais: local ou mundial, a depender do porte da organização.

Uma das formas estruturais que surgiram com o desenvolvimento tecnológico foi a empresa em rede, como definida por Castells (2002). O autor explica que o desempenho de uma determinada rede dependerá de dois critérios: conectividade, a capacidade estrutural de facilitar a comunicação sem ruídos entre os seus componentes, e coerência, isto é, na medida em que há interesses compartilhados entre os objetivos da rede e de seus componentes. E afirma que organizações bem sucedidas são aquelas capazes de: gerar conhecimento e processar informações com eficiência; adaptar-se à geometria variável da economia global; ser flexível o suficiente para transformar seus meios tão rapidamente quando mudam os 
objetivos sob o impacto da rápida transformação cultural, tecnológica e institucional; e inovar, já que a inovação torna-se a principal arma competitiva.

Com isso, surgem as tendências de flexibilidade no trabalho. Martin Carnoy (2000, como citado em Castells, 2002) coloca quatro tendências para a flexibilidade, motivadas pela concorrência e impulsionadas pela tecnologia, que fundamentam a atual transformação de padrões flexíveis de trabalho. Primeira, jornada de trabalho: trabalho flexível significa que não está restrito ao modelo tradicional de trinta e cinco a quarenta horas por semana em expediente integral. Segunda, estabilidade no emprego: o trabalho flexível é regido por tarefas e não inclui compromisso com permanência futura no emprego. Terceira, localização: embora a maioria ainda trabalhe regularmente no local de trabalho da empresa, um número cada vez maior de trabalhadores realizam suas atividades laborais fora do ambiente de trabalho, durante parte ou todo o período, em casa, em trânsito ou nas instalações de outra organização, pela qual sua empresa seja contratada. E quarta, o contrato social entre patrão e empregado: este tradicionalmente baseia-se em compromisso do patrão com os direitos bem definidos dos trabalhadores, níveis padronizados de salários, opções de treinamento, benefícios sociais e um plano de carreira previsível, ao passo que, do lado do patrão, espera-se que o empregado seja leal à empresa.

O setor administrativo do serviço público, apesar das transformações que vêm ocorrendo na administração pública, no decorrer da história, ainda é fortemente marcado pelos valores do modelo burocrático. Este, por sua vez, estabelecido no governo de Getúlio Vargas na década de 30 (trinta), com o propósito de eficiência e eficácia nas atividades públicas, com processos bem estabelecidos e utilização de mão de obra especializada, desenvolvendo tarefas específicas, com elevada verticalização hierárquica e cultura organizacional extremamente forte voltada à representação do poder.

De acordo com Weber (1978, como citado em Wilson, 1984) a burocracia assenta-se sobre as relações de poder nas organizações como uma forma de controle do aparelho social. E afirma ainda que apenas a burocracia foi capaz de implementar o fundamento para a administração de uma lei racional, com base na sistematização de regras formais, sancionados desde o seu surgimento com alto grau de perfeição técnica. O sociólogo alemão explica ainda que, no sistema capitalista, a índole própria da burocracia, sua virtude específica, evolui à medida que os processos são "desumanizados", afastando os assuntos relacionados a amor, ódio ou outros fatores de teor emocional, irracional, que fogem a todo cálculo.

Já Crozier (1981, como citado em Wilson, 1984), traz uma face negativa de burocracia, observando que o sistema burocrático de organização, diferente de todos aqueles em que predomina o circuito errosinformações-correções, não possui flexibilidade para se readaptar em função dos erros cometido.

Os processos burocráticos são adotados pela maioria das organizações ao redor do mundo, especialmente no âmbito da Administração Pública, o que não é diferente no Brasil. Neste contexto, Costa e Costa (2018) coloca que a história da Administração Pública brasileira tem início na colônia e seu ponto inaugural é a chegada da Família Real portuguesa ao Rio de Janeiro, em 1808, em que o Brasil passa a ser a sede administrativa e política, em que é elevada à Estado Nação.

Keinert (1994) divide a história da Administração Pública do Século XX no Brasil em fases, representadas por quatro paradigmas. O primeiro tem a administração pública como Ciência Jurídica, que vai de 1900 a 1929, como regras jurídicas, limitando seus problemas à elaboração de leis e regulamentos de aplicação, com todos os pormenores necessários para o seu cumprimento. 0 segundo paradigma como Ciência Administrativa, que vai de 1930 a 1979, fase marcada pela era Vargas, baseada na ideia de racionalização, calcada nas teorias da Escola Clássica da Administração, dando início ao crescimento da máquina governamental com vista a aumentar sua capacidade de intervenção, centralização e controle. 0 terceiro paradigma é o da Administração Pública como Ciência Política, entre os anos de 1980 e 1989, o modelo anterior demonstra falência, suscita a existência enquanto Ciência Administrativa Pública começa a utilizar-se de um instrumento teórico predominantemente oriundo das ciências políticas, poder estatal, dando menos ênfase à eficiência que à equidade e à adequação social. E por último o paradigma da Administração Pública como Administração pública, que começa a ser explorado a partir do ano de 1989 e vai até os dias atuais, em que se tem a presença e o fortalecimento da cultura democrática, na qual há uma maior participação popular na gestão pública.

A administração pública brasileira, assim como as diversas nações do mundo, é definida como um organismo complexo. É o Estado em ação que coloca é desenhado por meio da estrutura, do efetivo humano e da ação gerencial. Em que, estão vinculados respectivamente pela estrutura, pela burocracia e pelos processos (Costa \& Costa, 2018). 
Secchi (2009) coloca o modelo da Administração Pública Gerencial como pós-burocrática. E para que aja essa transição é necessário o setor ter como base os valores da produtividade, orientação aos serviços, descentralização e eficiência nos serviços.

Keinert (1994) justifica que é exigido ao Estado, diante das mudanças da sociedade atual, de forma rápida e dinâmica, que se adapte a este contexto fortemente marcado pelos avanços da tecnologia da informação, os quais impõem questões como agilidade, rapidez, flexibilidade, competitividade e, especialmente, qualidade nos serviços públicos. Isto demanda um novo Estado, novos valores, novos serviços e novo perfil dos servidores públicos.

Segundo Damanpour (1991) há duas estruturas no setor público, a mecanicista e a orgânica. Esta última está associada ao gerenciamento (ou poder) desconcentrado e especializado, para incentivar os níveis mais baixos no processo de inovação. Já a primeira, inclui a centralização de autoridade de tomada de decisão, que é visto para neutralizar a dispersão de poder e os altos níveis de participação necessários para inovação e a formalização, que se refere a grande quantidade de regras e procedimentos associado negativamente à inovação.

Esta diferença quanto à concentração/descentralização do poder interfere direta e decisivamente na cultura organizacional, a qual exerce influência muito grande sobre a discussão e implantação do home office parcial ou total, foco deste artigo, nas repartições públicas, as quais possuem como base a modalidade presencial.

No que concerne à cultura organizacional, esta é conceituada por Robert Ernst (1985, como citado em Fleury, 1986) como um sistema de valores e crenças compartilhados que modelam o estilo de administração de uma empresa e o comportamento cotidiano de seus empregados. Nessa direção, Fleury (1986), em seu artigo, traz três tipologias. A primeira tipologia colocada por Linda Smircich (1983 como citado em Fleury, 1986), que percebe a cultura em duas linhas de estudo: a primeira, relacionada a duas variáveis: uma variável independente, externa à organização (a cultura da sociedade em que se insere a organização, trazida por membros) e a outra variável interna (as organizações produzem bens, serviços e produtos culturais como lenda, ritos, símbolos) e a segunda linha como visão instrumental derivada da metáfora da máquina e como uma visão adaptativa derivada da metáfora do organismo.

A segunda tipologia colocada pela autora é a de Edgar Schein (1985 como citado em Fleury, 1986). Para ele, cultura organizacional é o conjunto de pressupostos básicos que o grupo inventou, descobriu ou desenvolveu ao aprender como lidar com os problemas de adaptação externa e integração interna. Esta teoria estabelece a cultura em três níveis: o primeiro, nível dos artefatos visíveis: o ambiente construído da organização, a arquitetura, a maneira como as pessoas se vestem, padrões de comportamento visíveis, documentos públicos (cartas, mapas, dentre outros); o segundo, nível dos valores que governam o comportamento das pessoas; o terceiro nível refere-se aos pressupostos inconscientes, os quais determinam como os membros de um grupo percebem, pensam e sentem.

A terceira tipologia é a de Pagès (1979 como citado em Fleury, 1986) cujo objetivo é estudar o poder nas organizações a partir de um quadro teórico, direcionado pelas seguintes perspectivas do ponto de vista da alienação econômica, que separa os trabalhadores dos meios de produção; como um fenômeno político de imposição e controle sobre as decisões e a organização do trabalho; sob a ótica ideológica, como um fenômeno de apropriação de significados e valores; e ao nível psicológico, como um fenômeno que aliena, resulta na dependência.

Para Fleury (1996) os momentos de crises vivenciados por uma organização são importantes para alavancar as mudanças na cultura organizacional. Nos períodos de estabilidade, as resistências a modificações em qualquer instância da vida organizacional são muito mais fortes. Segundo a autora, a crise pode ser provocada por fatores externos (econômicos ou políticos, por exemplo) ou internos (como o surgimento de novas lideranças). Ela é percebida de forma diferenciada pelos vários segmentos da organização, tanto em seu diagnóstico, como na compreensão da necessidade de mudança. Isto porque o momento da mudança é de ruptura, de transformação, de criação, o que envolve sempre risco principalmente o risco das alterações nas relações de poder.

Retomando a discussão no cenário da Administração Pública, na última metade do século XX e, mais ainda, no início do novo milênio, os governos têm sido pressionados a responder às demandas de seus cidadãos e à crescente complexidade e mudança em seus ambientes globais. Gerenciar o setor público, no ambiente atual de constantes mudanças, tornou-se um desafio para os formuladores de políticas, gerentes de prestação de serviços e funcionários públicos - um desafio especialmente assustador para os de países em desenvolvimento e países com economias em transição. Os governos enfrentam o grande desafio de 
oferecer serviço de maior alcance e qualidade, com recursos reduzidos e limitações na capacidade operacional, e ainda precisam tornar as instituições mais responsáveis, receptivas, eficientes e eficazes (Alberti \& Bertucci, 2006).

Conforme Corrêa (2008 como citado em Souza, 2011), a eficiência é a medida de quanto economicamente os recursos da organização são utilizados quando promovem determinado nível de satisfação dos clientes e outros grupos de interesse, realizando o serviço da melhor forma possível, enquanto a eficácia refere-se aos objetivos que se quer atingir, ou seja, está relacionado à satisfação das necessidades dos clientes e outros grupos de interesse da organização.

Atingir a eficiência e a eficácia por meio da inovação deve estar entre os objetivos de qualquer corporação, no entanto das diferenças existentes entre as organizações privadas e as estatais, Brandão (2012) coloca que o setor privado tende a valorizar mais inovações que se caracterizem pelo ineditismo, enquanto o setor público mais frequentemente adota inovações geradas originalmente em outras organizações, a imitação.

Inovação em gestão, definida por Birkinshaw, Hamel e Mol (2005) como a implementação de uma nova prática de gerenciamento, processo ou estrutura que altera significativamente a maneira como o trabalho é realizado e promove os objetivos organizacionais. Essas inovações possuem características diversas e podem ser influenciadas por diferentes fatores ambientais e organizacionais. 0 gerenciamento leva em consideração a implementação da ideia no ambiente de negócio: a ideia deve ser nova e o risco deve ser analisado, para alcançar objetivos organizacionais adicionais.

Brandão (2013), em sua pesquisa, observa que os principais tipos de inovação estudados no setor público são aqueles relacionados a serviço e processos, podendo estar incluídas inovações em estruturas e sistemas administrativos, assim como de cunho tecnológico. Destaca ainda estudos que buscam identificar antecedentes ambientais, organizacionais e gerenciais que influenciam a inovação no setor público.

Neste cenário de significativas mudanças na cultura e estrutura organizacionais, bem como intensas buscas pela otimização de recursos, através da melhoria da eficiência e eficácia nas corporações, o teletrabalho vem se fortalecendo nos últimos anos.

Konradt, Schmook e Malecke (2000) define Teletrabalho como uma forma de organização do trabalho que é realizado parcial ou totalmente feito fora do ambiente laboral da empresa com o auxílio de serviços de informação e telecomunicações.

Morganson, Major, Oborn, Verive e Heelan (2010), por sua vez, diz que trabalho remoto é realizado da residência ou de um escritório satélite, conectados em rede com a empresa, com foco no que diz respeito a espacialidade.

No território brasileiro, o Teletrabalho é colocado pela Lei no 13.467 no capítulo II no artigo 75-B que altera a Consolidação das Leis de Trabalho (CLT), conceituado como "[...] prestação de serviços preponderantemente fora das dependências do empregador, com a utilização de tecnologias de informação e de comunicação que, por sua natureza, não se constituam como trabalho externo" (Planato, 2017).

Malik, Rosenberger, Fitzgerald e Houlcroft (2016) traz em seu texto fatores positivos do teletrabalho tanto para as pessoas quanto para as organizações. A primeira se beneficia ao desenvolver seu trabalho em um ambiente do seu agrado, pela diminuição do estresse e a redução do desgaste físico com deslocamento, principalmente quando se trata de longas distâncias. Para as organizações existe a possibilidade de se ter funcionários mais qualificados, devido ao seu maior alcance e uma maior produtividade pessoal.

Tose, Covre, Soqueira e Binotto (2009) enfatizam a forma subjetiva do teletrabalho, em que as pessoas inicialmente criam um local para realização das atividades, home office, com estilo próprio; equipamentos personalizados, podendo optar por estrutura e comportamento tradicionais (colocar os móveis, a farda ou o que simbolize o trabalho) ou até mesmo de maneira informal: de camiseta, bermuda e sandália. Os autores colocam ainda que, a relação com os familiares pode ser administrado por meio de simbologia, em que o profissional pode colocar o crachá para informar que está trabalhando, e por outro lado o teletrabalhador desfruta dos prazeres de fazer as refeições em casa com calma, rodeado de familiares e dividir atividade do lar com a esposa ou vice-versa.

Segundo Filho, Oliveira, Samy e Nunes (2020) o teletrabalho proporciona aumento da produtividade e redução dos custos organizacionais. Em seu artigo coloca que chegou a ter um aumento de $129 \%$ na produtividade e uma redução no custo de espaço, o que impactava na despesa de manutenção. 
Para Silva, Vieira e Pereira (2015) a administração pública busca maior eficiência e eficácia com a adoção do teletrabalho, por meio do desempenho das tecnologias móveis permitindo a realização das atividades profissionais em qualquer localidade e da redução dos custos, já que, essa nova prática diminui a necessidade de infraestrutura predial e tecnológica.

\section{METODOLOGIA}

Para realização deste artigo foi elaborado um banco de dados composto por uma amostra de 433 elementos, por meio de pesquisa via formulário de opnião, survey, do Google Forms, aos funcionários públicos, no estado da Bahia, composta por quatorze perguntas, as quais constam na tabela 2 . 0 preenchimento dos formulários se deu entre os dias 03 e 11 de junho de 2020. A pesquisa, possui como recorte espacial o estado da Bahia, no Brasil, e setorial concernente aos servidores do setor administrativo da administração pública.

A estratégia empírica utilizada para obtenção da resposta a pergunta problema foi análise quantitativas amostral que utiliza os principais indicadores estatístico. As variáveis que compõem o modelo estão descritas no quadro 2, por meio de perguntas.

Quadro 2. Descrição das variáveis econométricas

\begin{tabular}{|c|c|c|c|}
\hline $\begin{array}{l}\text { Variável } \\
\text { empírica }\end{array}$ & Perguntas & Conteúdo da variável & Sigla \\
\hline Y & $\begin{array}{l}\text { O home office melhora a eficiência e } \\
\text { a eficácia da Administração } \\
\text { Pública? }\end{array}$ & $\begin{array}{l}\text { Captura a opinião do servidor público } \\
\text { referente a eficiência e eficácia do serviço } \\
\text { público com a prática da modalidade home } \\
\text { office. }\end{array}$ & efic \\
\hline $\mathrm{X} 1$ & $\begin{array}{l}\text { Você trabalhou home office no } \\
\text { período da pandemia? }\end{array}$ & $\begin{array}{l}\text { Captura se o servidor praticou alguma das } \\
\text { modalidades de home office, total ou parcial. }\end{array}$ & trab \\
\hline $\mathrm{X} 2$ & Qual sua faixa etária? & $\begin{array}{l}\text { Captura em qual faixa etária o servidor está: } \\
\text { até } 35 \text { (trinta e cinco) anos; Acima de } 45 \\
\text { (quarenta e cinco) anos; até } 60 \text { (sessenta) } \\
\text { anos e acima de } 60 \text { (sessenta) anos. }\end{array}$ & idade \\
\hline $\mathrm{X} 3$ & Qual gênero você se identifica? & $\begin{array}{l}\text { Obtém a informação de qual gênero o servidor } \\
\text { se identifica }\end{array}$ & sexo \\
\hline $\mathrm{X} 4$ & $\begin{array}{l}\mathrm{Na} \text { atividade de home office } \\
\text { qual(is) recursos você dispõe em } \\
\text { casa? }\end{array}$ & $\begin{array}{l}\text { Capta a informação de quais recursos } \\
\text { tecnológicos de comunicação o servidor utiliza } \\
\text { e detém em sua residência: computador, } \\
\text { internet, celular e ambiente apropriado. }\end{array}$ & rec \\
\hline $\mathrm{X} 5$ & $\begin{array}{l}\text { O que você achou do trabalho da } \\
\text { modalidade remota? }\end{array}$ & $\begin{array}{l}\text { Esta variável capta os pontos positivos e } \\
\text { negativos dos servidores em home office total } \\
\text { ou parcial: foco, motivação, qualidade de vida, } \\
\text { desempenho, queda na qualidade e dispersão } \\
\text { nas atividades profissionais. }\end{array}$ & desemp \\
\hline
\end{tabular}


Quadro 2. Descrição das variáveis econométricas

(Continuação...)

\begin{tabular}{|c|c|c|c|}
\hline $\begin{array}{l}\text { Variável } \\
\text { empírica }\end{array}$ & Perguntas & Conteúdo da variável & Sigla \\
\hline $\mathrm{X} 6$ & $\begin{array}{l}\text { Você acha que o home office, } \\
\text { trabalho realizado em casa, } \\
\text { poderia ser praticado pela área } \\
\text { administrativa do setor público, } \\
\text { após o período da pandemia? }\end{array}$ & $\begin{array}{l}0 \text { desejo do servidor do trabalho remoto após } \\
\text { o período de pandemia. }\end{array}$ & hppand \\
\hline $\mathrm{X} 7$ & $\begin{array}{l}\text { O que você acha do trabalho home } \\
\text { office parcial, dias presenciais e } \\
\text { dias a distância? }\end{array}$ & $\begin{array}{l}\text { Capita a percepção do servidor público } \\
\text { referente a modalidade de trabalho home } \\
\text { office parcial. }\end{array}$ & hopar \\
\hline $\mathrm{X} 8$ & $\begin{array}{l}\text { O que você acha do trabalho em } \\
\text { home office total, todos os dias a } \\
\text { distância, indo esporadicamente ao } \\
\text { trabalho presencial? }\end{array}$ & $\begin{array}{l}\text { Capta a percepção do servidor público } \\
\text { referente a modalidade de trabalho home } \\
\text { office parcial total. }\end{array}$ & hotot \\
\hline X9 & $\begin{array}{l}\text { Qual a modalidade de trabalho } \\
\text { você preferiria pra sua jornada de } \\
\text { trabalho? }\end{array}$ & $\begin{array}{l}\text { Capita em qual modalidade de trabalho (home } \\
\text { office total, parcial ou presencial) desejado } \\
\text { pelo servidor público. }\end{array}$ & mod. trab \\
\hline $\mathrm{X} 10$ & $\begin{array}{l}\text { Qual o seu vínculo com o serviço } \\
\text { público? }\end{array}$ & $\begin{array}{l}\text { Capta o vínculo do servidor com o servidor } \\
\text { público: CLT, estatutário, Polícia Militar da } \\
\text { Bahia, Nomeação, Reda, outros. }\end{array}$ & vinc \\
\hline $\mathrm{X} 11$ & $\begin{array}{l}\text { Na estrutura organizacional, onde } \\
\text { você está localizado(a)? }\end{array}$ & $\begin{array}{l}\text { Qual o cargo ou função ocupada no serviço } \\
\text { público: Institucional, tático ou operacional. }\end{array}$ & estrut \\
\hline $\mathrm{X} 12$ & Em qual modalidade? & $\begin{array}{l}\text { Capta qual a modalidade de trabalho praticado } \\
\text { pelo servidor público no período da pandemia, } \\
\text { home office parcial ou total. }\end{array}$ & mod \\
\hline
\end{tabular}

Fonte: desenvolvida pelo autor.

\section{ANÁLISE DOS RESULTADO}

Inicialmente serão apresentados os dados relevantes que fazem parte dos resultados da pesquisa de opinião, survey. No período da pandemia da Covid-19, na amostra de 433 servidores percebe-se que o número de pessoas que desejam a modalidade home office após o período da pandemia é superior a quantidade de pessoas que trabalharam na modalidade teletrabalho, como mostra a tabela 1. Isso leva a entender que parte dos servidores que estavam realizando suas atividades no formato presencial, também desejam, no futuro, o home office. 
Tabela 1. Opinião sobre home office

\begin{tabular}{|l|c|c|c|c|}
\hline \multicolumn{1}{|l|}{ Elementos do questionário } & \multicolumn{1}{c|}{ Nimão } & Não sabe opinar & Total \\
\hline $\begin{array}{l}\text { Servidores que trabalharam na modalidade } \\
\text { home office no período da pandemia da } \\
\text { COVID-19. }\end{array}$ & $69,52 \%$ & $30,48 \%$ & $0 \%$ & $100,00 \%$ \\
\hline $\begin{array}{l}\text { O que o servidor acha do trabalho home } \\
\text { office ser praticado pela área } \\
\text { administrativa do setor público, após o } \\
\text { período da pandemia. }\end{array}$ & $73,67 \%$ & $17,09 \%$ & $9,24 \%$ & $100,00 \%$ \\
\hline
\end{tabular}

Fonte: desenvolvida pelo próprio autor

No tocante a percepção das modalidades parcial ou total do home office, os participantes da pesquisa de opinião tiveram maior aceitação da forma parcial do que a total. Na tabela 2, ao observar a pontuação das grades, é percebido maiores representações percentuais nas colunas de percepção positiva (bom, ótimo e excelente) e quando esses pontos são somados, a modalidade parcial representa $72,98 \%$ e a modalidade total $57,51 \%$. Isso demonstra que, o servidor público do setor administrativo, de acordo a sua experiência no período da pandemia, teve uma maior identificação com trabalho em home office parcial.

Tabela 2. Percepção do home office total e parcial

\begin{tabular}{|l|c|c|c|c|c|c|c|}
\hline \multicolumn{2}{|c|}{ Péssimo } & Ruim & $\begin{array}{c}\text { Não } \\
\text { sabe } \\
\text { opinar }\end{array}$ & Bom & Ótimo & Excelente & Total \\
\hline $\begin{array}{l}\text { O que você o servidor acha do } \\
\text { home office total, no período } \\
\text { de pandemia. }\end{array}$ & $6,00 \%$ & $20,79 \%$ & $15,70 \%$ & $28,41 \%$ & $15,01 \%$ & $14,09 \%$ & $100,00 \%$ \\
\hline $\begin{array}{l}\text { O que você o servidor acha do } \\
\text { home office parcial, no período } \\
\text { de pandemia. }\end{array}$ & $2,31 \%$ & $9,01 \%$ & $15,70 \%$ & $36,72 \%$ & $22,63 \%$ & $13,63 \%$ & $100,00 \%$ \\
\hline
\end{tabular}

Fonte: desenvolvido pelo próprio autor

Outro ponto importante para a realização das atividades laborais, fora da estrutura física organizacional, é o conjunto de recursos utilizado por ele em seu lar, como equipamentos eletrônicos e acesso a rede de internet. 0 que se percebe é que, a maioria dos envolvidos na pesquisa possuem as ferramentas necessárias para o desenvolvimento das suas atividades profissionais em seu novo espaço, como mostra o gráfico 1, em número absolutos, o que impacta diretamente na eficiência e eficácia do serviço público praticado na modalidade home office nesse setor. Tose, Covre, Soqueira e Binotto (2009) enfatizam a forma subjetiva do teletrabalho, em que as pessoas inicialmente criam um local para realização das atividades, home office, com estilo próprio; equipamentos personalizados, podendo optar por estrutura e comportamento tradicionais (colocar os móveis, a farda ou o que simbolize o trabalho) ou até mesmo de maneira informal: de camiseta, bermuda e sandália. 
Gráfico 1. Recursos utilizados no home office

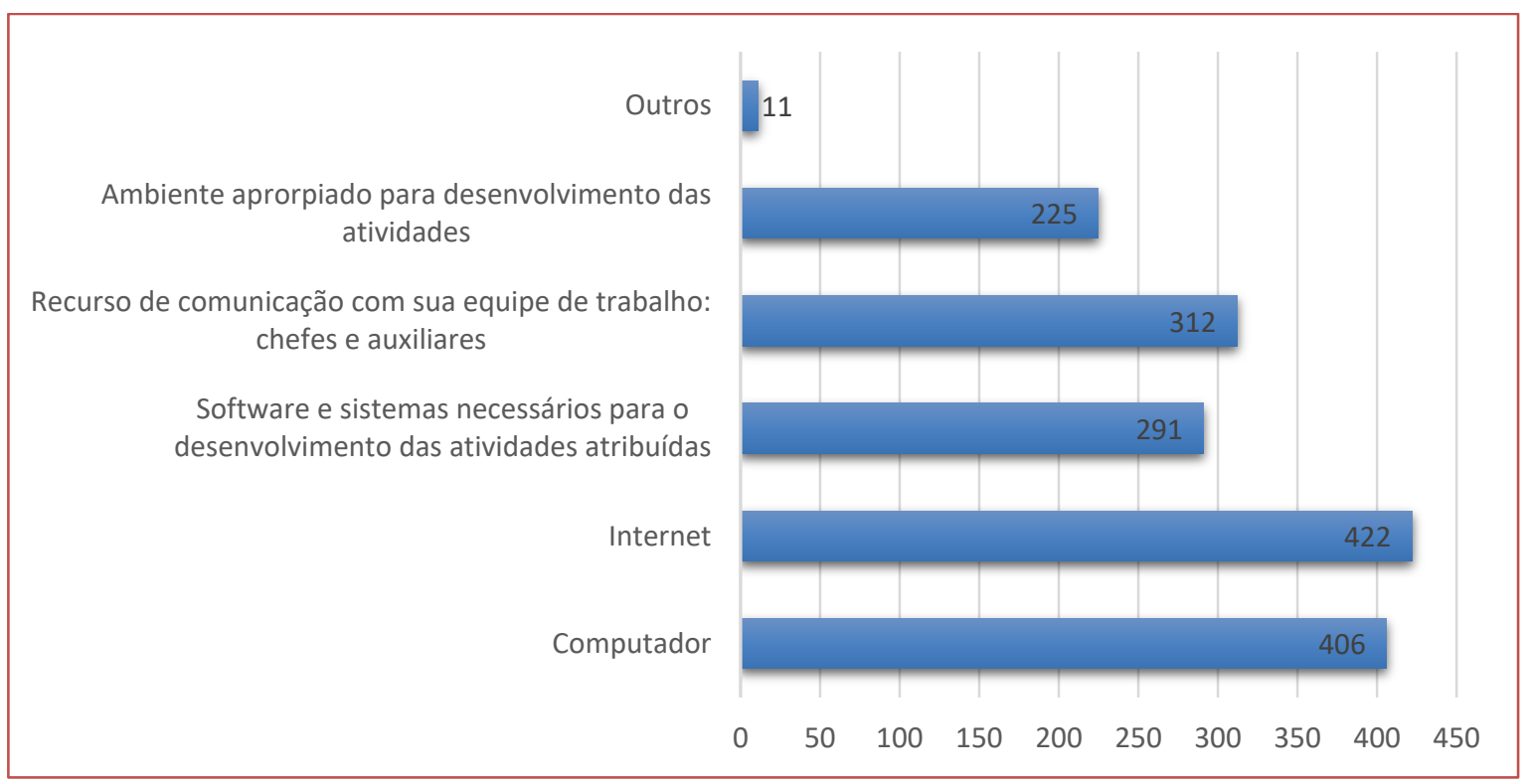

Fonte: desenvolvido pelo próprio autor

O incomodo que motivou este artigo, representado pela pergunta problema, colocado é referente a eficiência e eficácia do serviço público com os servidores praticando home office, se esta modalidade contribui para este princípio organizacional. De acordo a resposta dos participantes da pesquisa $69,98 \%$ concordam, pouco, muito ou totalmente, somados, que o teletrabalho melhorou a eficiência e a eficácia do serviço público praticado pelo setor administrativo, como mostra a tabela 3. Para Silva, Vieira e Pereira (2015) a administração pública busca maior eficiência e eficácia com a adoção do teletrabalho, por meio do desempenho das tecnologias móveis permitindo a realização das atividades profissionais em qualquer localidade

Tabela 3. Eficiência e eficácia

\begin{tabular}{|l|c|c|c|c|c|c|c|}
\hline \multicolumn{7}{|c|}{ O home office melhora a eficiência e a eficácia na Administração Pública } \\
\hline & $\begin{array}{c}\text { Discorda } \\
\text { Totalmente }\end{array}$ & $\begin{array}{c}\text { Discorda } \\
\text { muito }\end{array}$ & $\begin{array}{c}\text { Discorda } \\
\text { pouco }\end{array}$ & $\begin{array}{c}\text { Concorda } \\
\text { pouco }\end{array}$ & $\begin{array}{c}\text { Concorda } \\
\text { muito }\end{array}$ & $\begin{array}{c}\text { Concorda } \\
\text { totalmente }\end{array}$ & Total \\
\hline$\%$ & $5,31 \%$ & $9,70 \%$ & $15,01 \%$ & $30,95 \%$ & $28,18 \%$ & $10,85 \%$ & $100 \%$ \\
\hline Frequência & 23 & 42 & 65 & 134 & 122 & 47 & 433 \\
\hline
\end{tabular}

\section{CONSIDERAÇÕES FINAIS}

A pandemia da Covid-19 trouxe inúmeras modificações para rotina da pulação mundial. Uma delas foi a mudança do ambiente de trabalho que saiu do teto das empresas e foi para o teto dos lares de cada trabalhador. Para responder a pergunta problema colocada na introdução desta pesquisa foi realizada pesquisa de opinião com 433 funcionários públicos que deu forma a um banco de dados para sua devida análise estatística obtendo os seguintes resultados.

Inicialmente foi constatado que $69,52 \%$ das pessoas já possuíam alguma experiência na modalidade pesquisada, em que $73,67 \%$ das pessoas entrevistadas afirmaram que a modalidade deveria ser pratica, mesmo após o perído da pandemia. Concernente a modalide total ou parcial a maioria dos participantes tiveram preferência pela forma parcial. Malik, Rosenberger, Fitzgerald e Houlcroft (2016) traz em seu texto fatores positivos do teletrabalho tanto para as pessoas quanto para as organizações. A primeira se beneficia ao desenvolver seu trabalho em um ambiente do seu agrado, pela diminuição do estresse e a redução do desgaste físico com deslocamento, principalmente quando se trata de longas distâncias 
Outro resultado importante foi os servidores possuíam recursos que proporcionavam bom desempenho das atividades profissionais realizadas à distância.

Por fim, como resposta da indagação principal desta pesquisa foi que a maioria dos participantes concordam que o home office melhora a eficiência e a eficácia da Administração Pública.

Tal resultado possibilita a desmistificação cultural, fortemente defendida, de que as atividades laborais do setor público administrativo têm que ser desenvolvidas, única e exclusivamente, de forma presencial, com rígido controle de horário de entrada e saída.

Assim, este artigo tem como contribuição ampliar a discussão na comunidade acadêmica, proporcionar uma fundamentação teórico e empírica paras as instituições públicas que pretendam adotar a modalidade, já que o home office tende a se expandir com os movimentos na evolução da sociedade trabalhista, dos recursos tecnológico e seu acesso pelas pessoas.

\section{REFERÊNCIAS}

[1] Alberti, A., \& Bertucci, G. (2006). Replicating innovations in governance: na overview. Innovations in governasse and public administration: replicating what works. Department of Economic and Social Affairs. United Nations, New York.

[2] Almeida, F. D. A., \& Nogueira, A.J.F.M. (2019, outubro). As relações de trabalho na modalidade home office em empresas de bens de consumo. XLIII encontro da ENPAD - EnANPAD, São Paulo, SP.

[3] Birkinshaw, J., Hamel, G., \& Mol, M.J (2005, julho). Management innovation. A Working Paper, Série: 021.

[4] Castells, Manuel (2002). A sociedade em rede. A era da informação: economia, sociedade e cultura (Vol 1). São Paulo, SP, ed. Paz e Terra.

[5] Costa, J.L.C, \& Costa, M.L.C. (2018, outubro). História e representações da Administração Pública brasileira. EnANPAD, Curitiba, PR.

[6] Damanpour, F. (1991). Organizational innovation: a meta-analysis os effects of determinants and moderators. Academy of Management Journal, 34(3), 555-590.

[7] Decreto no 19.528 de 16 de março de 2020. (2020). Institui, no âmbito do Poder Executivo Estadual, o trabalho remoto, na forma que indica, e dá outras providências. Salvador, BA. Recuperado de http://www.casacivil.ba.gov.br/arquivos/File/dec19528DE16DEMARCODE2020.pdf

[8] Filho, J.A.N., Oliveira, M.A.M., Samy, F.P.C., \& Nunes, A. (2020, abril/junho). O teletrabalho como indutor de aumentos de produtividade e da racionalização de custos: uma aplicação empírica no Ministério da Justiça e Segurança. RSP-Revista do Servidor Público, Brasília, 71(2), 274-296.

[9] Fleury, M. (1987, outubro/dezembro). Estórias, mitos, heróis - cultura organizacional e relações do trabalho. RAE-Revista de Administração de Empresas, Rio de Janeiro, RJ, 27(4), 7-18.

[10] Fleury, M.T.L. (1996). Cultura e poder das organizações. São Paulo, SP: Editora Atlas, 2 ${ }^{\underline{a}}$ ed.

[11] Keinert, T.M.M. (1994, maio/junho). Os paradigmas da Administração Pública no Brasil. Análise da evolução do campo de conhecimento em administração pública através dos paradigmas dominantes dos diversos períodos entre 1900-92. RAE - Revista de Administração de Empresas. São Paulo, SP, 34(3), 41-48.

[12] Konradt, U., Schmook, R., \& Malecke, M. (2000). Impacts of telework on individuals, organizations and families: a critical review. International Review of Industrial and Organizational Psychology, 15, 63-100.

[13] Lei no 13.467, de 13 de julho de 2017. (2017). Altera a Consolidação das Leis do Trabalho (CLT), aprovada pelo Decreto-Lei no 5.452, de $1^{\circ}$ de maio de 1943, e as Leis $\mathrm{n}$ ㅇ 6.019, de 3 de janeiro de 1974, 8.036, de 11 de maio de 1990, e 8.212, de 24 de julho de 1991, a fim de adequar a legislação às novas relações de trabalho. Brasília, DF. Recuperado de http://www.planalto.gov.br/ccivil_03/_Ato2015-2018/2017/Lei/L13467.htm

[14] Malik, A.P.J., Rosenberger, P. J., Fitzgerald, M., \& Houlcroft, L. (2016). Factors affecting smart working: evidence from Australia. International Journal of Manpower, 37(6), 1042-1066.

[15] Morganson, V. J., Major, D. A., Oborn, K. L., Verive, J. M., \& Heelan, M. P. (2010). Comparing telework locations and traditional work arrangements: differences in work-life balance support, job satisfaction, and inclusion. Journal of Managerial Psychology, 25, 578-595.

[16] Secchi, L. (2009, março/abril). Modelos organizacionais e reformas da administração pública. RAP- Revista de Administração Pública, Rio de Janeiro, RJ, 43(2), 347-369.

[17] Silva, R.S.P. (2017). A carreira de profissionais de TI em sistema home office (Dissertação da Pós-Graduação em Administração). Pontifícia Universidade Católica de São Paulo, São Paulo. 
[18] Silva, V.G., Vieira, A.M., \& Pereira, R.S. (2015, setembro/dezembro). A gestão do teletrabalho: nova realidade ou mera adaptação à tecnologia? Revista Perspectivas Contemporâneas, 10(3), 35-55.

[19] Souza, Souza \& Benedito, Jose \& Kyrillos, Sergio \& José, Francisco \& Milreu, Francisco. (2011). Eficiência e eficácia: uma abordagem sobre as tarefas da gestão da manutenção na interface do modelo entradatransformação-saída. Journal of Public Administration Research and Theory, 18(4), 591-615.

[20] Tose, M.G.L., Covre, M.L.M., Siqueira, E.S., \& Erlaine, B. (2009, novembro). Organização, trabalho e tecnologia: o impacto do teletrabalho na dimensão subjetiva dos sujeitos. Encontro de Gestão de Pessoas e Relações de Trabalho, Curitiba, PR.

[21] Wilson. P., Jr. (1984, julho/setembro). Burocracia(s) e (des)burocracia. RAP-Revista de Administração Pública, 18(3); 4-17.

[22] Wooldridge, J.M. (1960). Introdução à econometria: uma abordagem moderna. São Paulo, SP, Thonson Learning.

[23] Worl Health Organization. (2020). Q\&As on Covid-19 and related health topics. Genebra, Switzerland. Recuperado de https://www.who.int/emergencies/diseases/novel-coronavirus-2019/question-and-answers-hub/q-adetail/q-a-coronaviruses 


\section{Capítulo 2}

\section{Como é a percepção de um programa de voluntariado}

no meio universitário?

\section{Beatriz Naemi Genovez Aoki \\ Christiano França da Cunha}

Resumo: 0 presente trabalho de conclusão de curso trata da percepção sobre um projeto de Trabalho Voluntário para o público universitário. 0 estudo teve como principal objetivo a investigação a respeito da viabilidade do desenvolvimento de um Programa de Voluntariado para uma ONG de cunho social e/ou ambiental. Tal estudo se caracterizou como descritivointerpretativo, com base em dados que foram coletados por meio de formulário estruturado disponibilizado para respostas em meio universitário, como forma de selecionar o público alvo. Os dados coletados na pesquisa revelaram aspectos muito importantes do quadro atual, do perfil do universitário que seria o público do Programa de Trabalho Voluntário. E tais dados acabaram por despertar inúmeras questões de viabilidade, tais como: como escolher as pessoas adequadas para garantir a efetividade do projeto? Deve ser realizado um estudo do público adequado para cada atividade voluntária. Qual a garantia de que os voluntários escolhidos trarão os resultados esperados para a Organização? É difícil ter certeza que o rendimento dos voluntários escolhidos será atingido plenamente, mas com um estudo e análise das pessoas escolhidas é possível reduzir a margem de erro. Esses questionamentos surgem por se tratar de uma atividade de longa duração, que requer um comprometimento elevado. 0 nicho de oportunidade do meio universitário é amplo, abrindo espaço para a implementação de um Programa de Voluntariado de longa duração. A Instituição que decidir implementar tal Programa deve realizar um planejamento detalhado das ações e de tudo aquilo que é responsabilidade do voluntário, deixar claro o que será oferecido como apoio à ação, garantindo a segurança e integridade do indivíduo que está disposto a auxiliar, bem como definir o perfil de voluntário específico que deseja incluir em suas atividades, ou seja, alinhar as características que o voluntário precisa ter, tais como ser universitário, se enquadrar em determinada faixa etária.

Palavras-chave: 1. voluntário 2. responsabilidade 3. universitário 4. impacto 5. outro 


\section{REVISÃO DE LITERATURA}

Desde a década de 1990, com a Ação da Cidadania contra a Miséria e pela Vida, a consciência de solidariedade e da importância do trabalho voluntário passou a fazer parte do cotidiano da sociedade, foi um importante marco para garantir a relevância de um setor social, ambiental e econômico. Foram organizadas ações pontuais, imediatas e estruturais de auxílio àqueles mais desfavorecidos, além da tentativa de pressionar o Estado para a formulação de políticas públicas que garantam os direitos do cidadão, para uma vida digna (JUNQUEIRA, 2002).

0 trabalho voluntário não envolve remuneração, trata-se de uma dedicação para determinado auxílio, seja de causa social ou ambiental. As atividades podem ser desempenhadas em creches, asilos, hospitais, área de preservação, cooperativas, entre outras instituições. Em geral, não há exigência de um grau específico de escolaridade e a restrição da faixa etária varia de acordo com a complexidade do problema tratado nas atividades (LANDIM; SCALON, 2000).

0 adjetivo latino voluntariuns da origem a palavra voluntário, que tem como significado a capacidade de escolha ou decisão. Segundo a Organização das Nações Unidas (ONU), voluntário é "o jovem ou adulto que, devido ao seu interesse pessoal e ao seu espírito cívico, dedica parte de seu tempo, sem remuneração alguma, a diversas formas de atividade, organizadas ou não, de bem-estar social ou outros campos" (ONU, 2018).

Para a Constituição brasileira (Lei Federal no 9.608 e do Decreto no 2.536)

“Trabalho voluntário é a atividade não remunerada prestada por pessoa física a entidade pública de qualquer natureza ou a instituição privada sem fins lucrativos que tenha objetivos cívicos, culturais, educacionais, científicos, recreativos ou de assistência social, inclusive mutualidade" (CARDOSO, 1998, p.1).

Em um estudo realizado pela Fundação Abrinq pelos Direitos da Criança, foi feita a definição de que voluntário é um ator social, agente de transformação, que presta serviços não remunerados em benefício da comunidade, doando seu tempo e conhecimento. Trata-se do atendimento tanto das necessidades do próximo quanto às suas motivações particulares (CORULLON, 2015).

Além de analisar o conceito da palavra é importante observar a motivação das pessoas para atuar voluntariamente. De acordo com inúmeros estudos, o altruísmo, solidariedade aliado ao interesse próprio montam, de uma maneira generalizada, o quadro de motivação. (AZEVEDO, 2008). 0 altruísmo envolve a percepção da desigualdade apresentada na sociedade, em relação a condição de vida, poder aquisitivo, acesso a direitos e bens. Isso faz com que as pessoas se sintam compelidas a ajudar aqueles que apresentam uma realidade de certa forma prejudicada em relação a sua própria (CORULLON, 2015).

E, nesse caso, pode-se observar uma forte compaixão e empatia, um ímpeto de transformação e mudança. A participação segue um propósito maior de atingir objetivos coletivos, cuja responsabilidade vai além das privadas.

É importante o entendimento do significado do Terceiro Setor no Brasil. É um termo sociológico utilizado para nomear Instituições de iniciativas privadas, porém, sem fins lucrativos e que direcionam seus objetivos para o bem comum. A grande maioria da mão de obra do Terceiro Setor é voluntária, é realizado um trabalho em conjunto com a sociedade em busca de uma vida digna para crianças, adultos e idosos, em harmonia com o meio ambiente (TACHIZAWA, 2014).

As ações vão desde atendimento médico, evento cultural, atividade de recreação, inserção na sociedade, campanhas educacionais, projetos de sustentabilidade e preservação do meio ambiente, desenvolvimento de cooperativas em comunidades.

Independente da abrangência, os projetos desenvolvidos no Terceiro Setor buscam amenizar os efeitos da grande desigualdade social e econômica observada no país. É importante lembrar, que a presença de tal setor não anula a função do Estado, o Terceiro Setor vem como uma alternativa eficaz que auxilia na resolução de problemas de causa social, ambiental e econômica (TACHIZAWA, 2014).

Dentre as Instituições do Terceiro Setor, estão as ONGs (Organização Não Governamental), que são mantidas por pessoas físicas, fundações, empresas privadas e colaboração do governo. (BLUNE, MARMENTINI, 2015). Elas podem ter como foco as causas sociais (erradicação da pobreza, redução da fome, inserção de minorias, acesso à educação e saúde) ou causas ambientais (restituição de áreas 
desmatadas por indústrias, preservação de áreas verdes, conscientização da população, dando a devida importância ao meio ambiente que nos oferece tantos recursos) (SILVEIRA, 2015).

Tais entidades têm uma responsabilidade em relação ao poder público: oferecer novos insumos na busca por soluções dos desafios sociais e ambientais. Nesse caso, para garantir que não ocorrerá desvio de dinheiro, é importante a conferência dos documentos institucionais (formalização jurídica, estatuto, demonstração contábil), dos relatórios de atividades, tendo em vista o impacto gerado pela Instituição, por meio de provas sociais, seja depoimento dos beneficiários, veiculações na mídia pela rede de parceiros e da equipe que está por trás das ações desenvolvidas (TOZZI, 2015).

Segundo estudo de Mônica Corullón (2015), o Terceiro Setor, cumpre basicamente as funções de iniciar novas ideias e processos, influenciar políticas públicas - podem exercer influência direta na formatação e promoção de políticas públicas - apoiar minorias ou interesses locais e promover parcerias. Indo um pouco além, é possível observar a atuação do Terceiro Setor no auxílio de outros países: as organizações voluntárias oferecem ajuda em situações onde o auxílio dos governos seria politicamente inaceitável, promovendo a cidadania participativa e o altruísmo além do território nacional (TACHIZAWA, 2014).

A adesão de um número elevado de pessoas é imprescindível para o impacto atingido pelo trabalho voluntário e para que tal atividade continue crescendo cada vez mais, é necessário que a opinião do voluntário seja levada em consideração (CAVALCANTE, 2013).

O perfil do voluntário passou por uma transformação ao longo do tempo, hoje, trata-se de um indivíduo engajado, atuante e consciente da realidade a que se enquadra e daquela que irá ajudar. Há uma variação quanto ao grau de comprometimento, determinadas atividades, de longa duração ou permanentes, requerem um compromisso maior, uma vez que o objetivo tem alcance maior e duradouro, levando inclusive ao que chamamos de "profissionalizaçao voluntária". Nos deparamos também com atividades pontuais e específicas, cuja duração é reduzida e atrai um perfil específico de voluntário. Ambas apresentam a mesma importância, uma vez que visam atingir objetivos de melhoria na realidade do outro (FERREIRA; PROENÇA; PROENÇA, 2008)

Sobolh e Widman (2011) ressaltam a necessidade de um processo de aprendizagem ao longo da elaboração de um projeto de voluntariado. Tal aprendizagem deve envolver uma convivência social, contemplando o aprender a conviver com a diferença, aprender a comunicar, aprender a interagir, a decidir em grupo, a zelar pela saúde, a cuidar do ambiente e aprender a valorizar o saber social.

No ano 2000, a Organização das Nações Unidas (ONU), fez uma análise profunda dos maiores problemas mundiais e estabeleceu 8 Objetivos do Milênio, tratam-se de 8 Jeitos de Mudar o Mundo.

"São eles:

1. Acabar com a fome e a miséria

2. Educação básica de qualidade para todos

3. Igualdade entre sexos e valorização da mulher

4. Reduzir a mortalidade infantil

5. Melhorar a saúde das gestantes

6. Combater a Aids, Malária e outras doenças

7. Qualidade de vida e respeito ao ambiente

8. Todo mundo trabalhando pelo desenvolvimento"

(PENA, 2000, p.1)

Tais objetivos, se alcançados pelos países, irão contribuir para a melhoria na qualidade de vida de uma parcela significativa da população. Uma única ação de um projeto de voluntariado pode ter um alcance que envolve questões sociais, ambientais, de saúde, educação. 


\section{METODOLOGIA}

0 presente trabalho se trata de uma pesquisa descritiva, que de acordo com Cervo, Bervian e Silva (2007), tem objetivo de analisar e verificar as características do perfil universitário quando o assunto é trabalho voluntário. Com base na formulação de perguntas, analisou-se as variáveis e a relação entre as respostas, a fim de verificar a percepção do universitário frente a um programa de voluntariado.

Quanto à abordagem, foi realizada uma pesquisa quantitativa, que segundo Marconi e Lakatos (2011), na qual o procedimento de coleta das informações foi um questionário bem estruturado, com perguntas claras e objetivas, que fossem capazes de traduzir as informações em números estatísticos, resumindo assim os dados de forma numérica. Tal abordagem se mostra eficiente, uma vez que prioriza os resultados numéricos para uma adequada avaliação de comportamento dos indivíduos de determinado grupo.

A população escolhida como objeto de estudo foi um grupo de 210 universitários do interior do Estado de São Paulo, de universidades públicas e privadas. Trata-se de uma amostragem não probabilística intencional, ou seja, só participaram indivíduos que contribuiriam significativamente para a pesquisa. 0 meio de divulgação da pesquisa foi o Facebook (meio digital), durante duas semanas.

Além disso, foi feita uma análise secundária de dados referentes à experiência de voluntárias em projeto de uma ONG que realiza ações em benefício à Amazônia e a população que la habita.

\section{ANÁLISE DE RESULTADOS}

Analisando o resultado da pesquisa, pode-se perceber na Figura 1 que 58,1\% dos estudantes nunca realizaram trabalho voluntário com duração superior à 3 dias, apresentando-se como um nicho de oportunidade para que Instituições tanto de causa social, quanto ambiental desenvolvam projetos de auxílio mais longo (Figura 2)

Figura 1. Respostas à questão: Você já fez trabalho voluntário com durabilidade superior a três dias consecutivos?

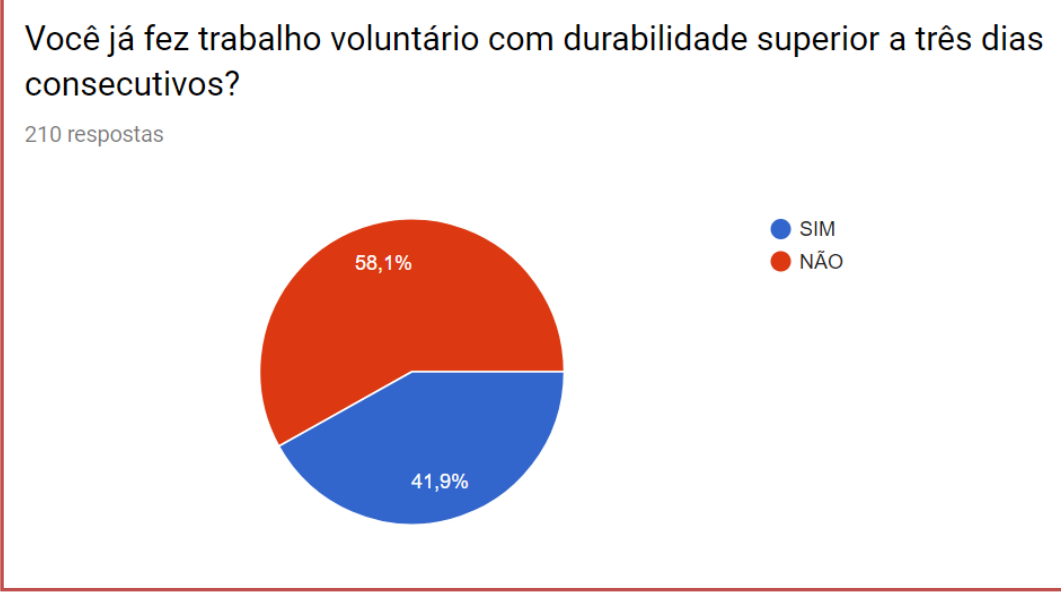

Fonte: Dados de Pesquisa 
Figura 2. Respostas à questão: Há interesse por trabalho voluntário de qual causa?

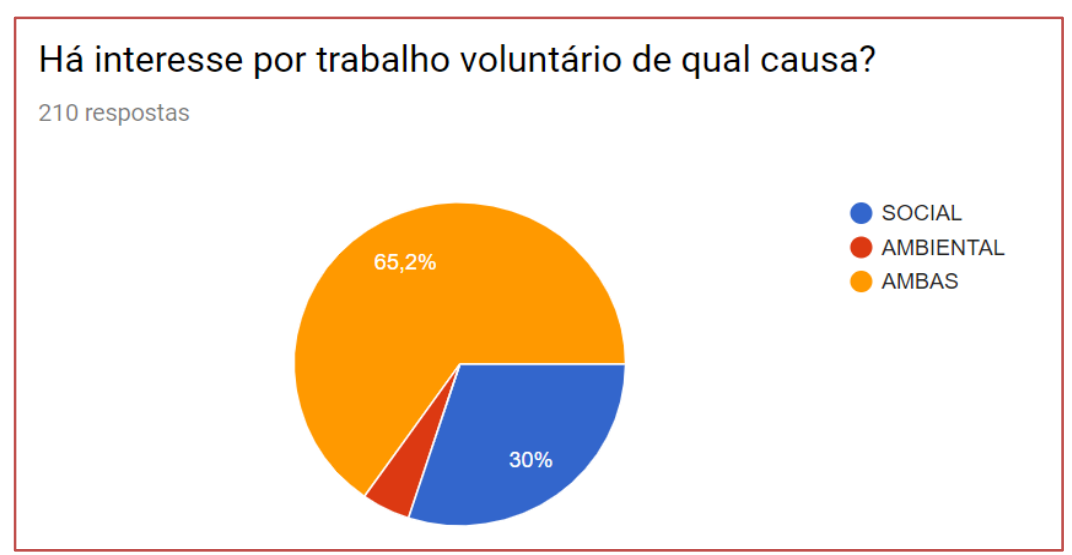

Fonte: Dados da Pesquisa

Além disso, é importante ressaltar que não é um pré-requisito a realização da atividade em grupo de pessoas conhecidas, os estudantes demonstraram independência nesse momento. Mas para a maioria, é importante que haja um contato prévio da equipe para alinhar objetivos e expectativas. $57,6 \%$ dos entrevistados negaram que a eficiência do trabalho seja dependende da realização um grupo de pessoas conhecidas.

Figura 3. Respostas à questão: Você acredita que o trabalho seja mais eficiente em um grupo de pessoas conhecidas?

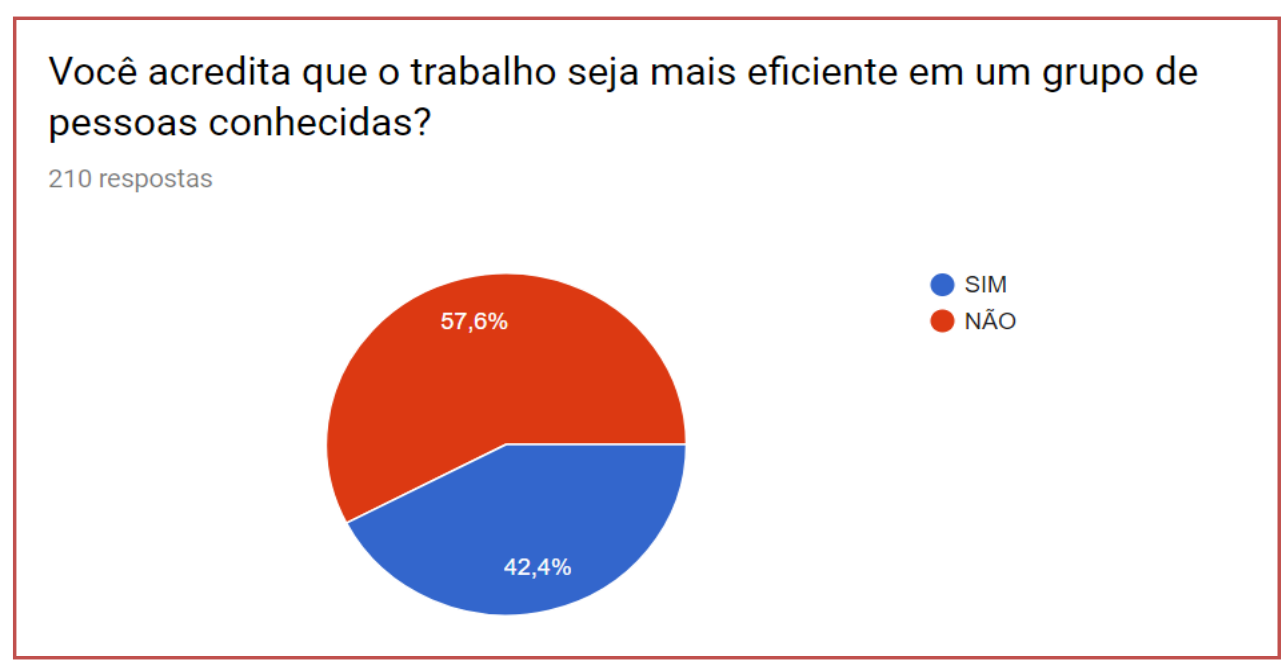

Fonte: Dados de Pesquisa

Apenas $15,7 \%$ dos estudantes já realizaram trabalho voluntário em outro Estado que não o seu de residência (Figura 4), e 75,7\% tem interesse em realizar esse tipo de atividade. 0 conhecimento de uma nova cultura aliado a atividade voluntária desperta ainda mais interesse, uma vez que une duas importantes causas e garante que a finalidade do trabalho voluntário de maior extensão tenha um alcance a longo prazo. 
Figura 4. Respostas à questão: Já realizou trabalho voluntário em outro Estado?

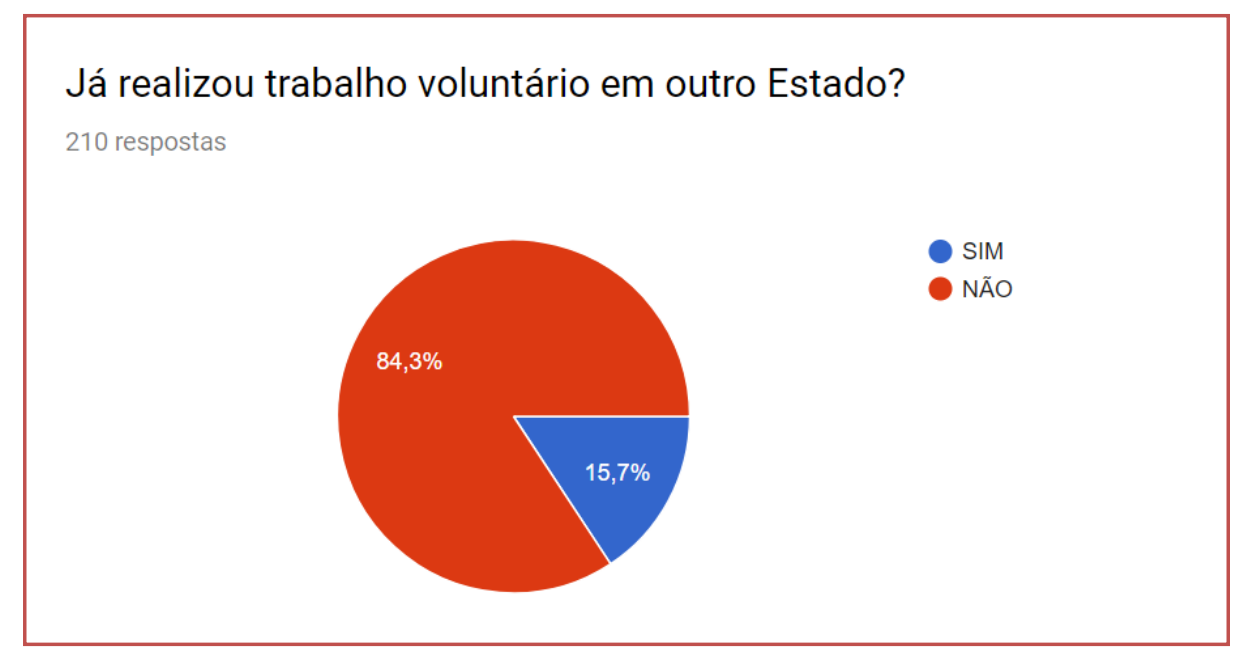

Fonte: Dados da Pesquisa

Figura 5. Respostas à questão: Você realizaria trabalho voluntário em qualquer Estado do Brasil?

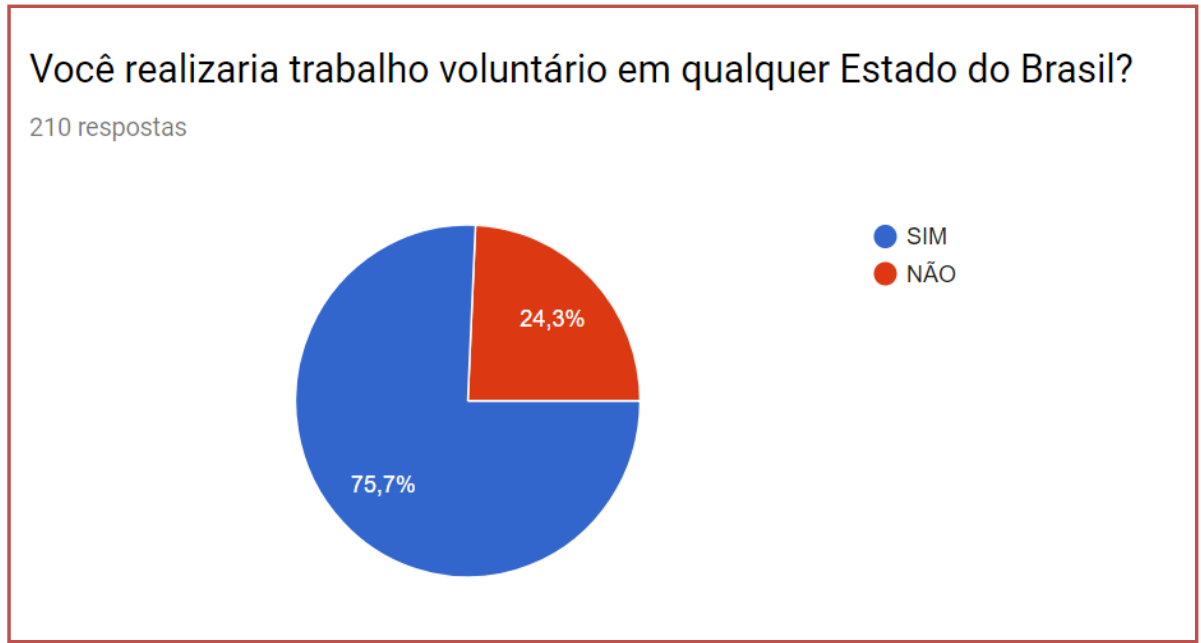

Fonte: Dados de Pesquisa

De acordo com a Figura 5, temos um público dividido em dois grupos: aqueles que têm interesse pela realização de uma atividade voluntária de maior duração e aqueles que restringem o voluntariado à ações pontuais. Para $83,3 \%$ dos entrevistados, o objetigo de um trabalho voluntário de maior extensão tem como finalidade um alcance de longo prazo (Figura 4). 
Figura 6. Respostas à questão: Pra você, o objetivo de um trabalho voluntário de maior extensão tem como finalidade alcance de curto ou longo prazo?

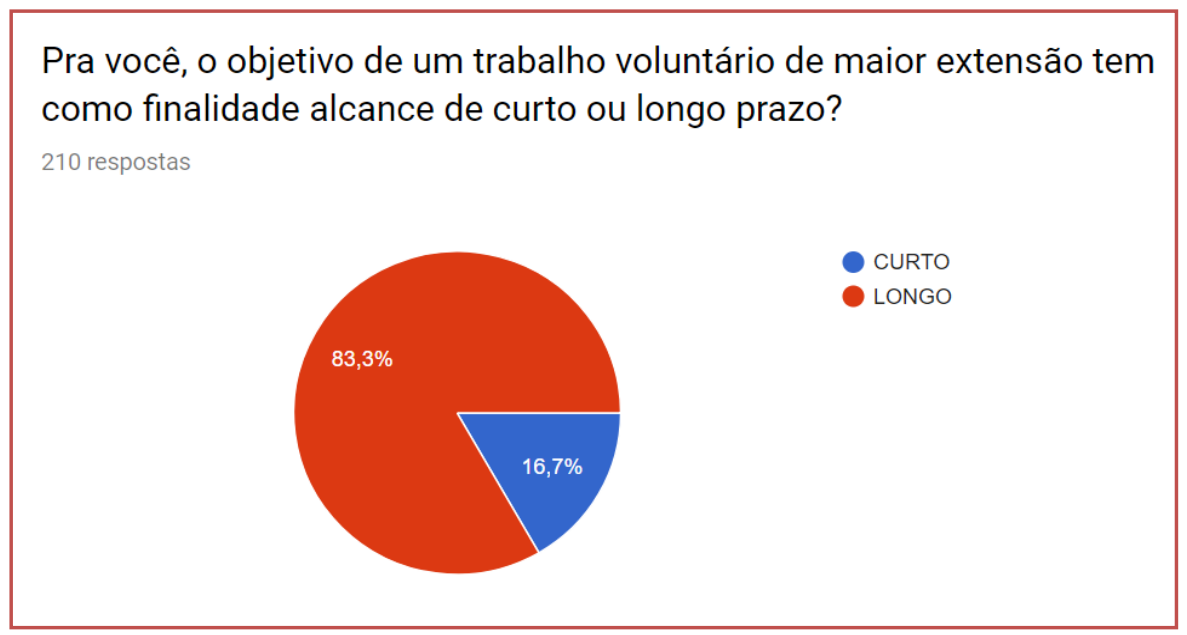

Fonte: Dados de Pesquisa

Cabe à Instituição definir as áreas e projetos que precisam de voluntários nos períodos das férias escolares (julho e dezembro, janeiro), o importante é ser uma lista específica de datas e quantidade de voluntários necessária para cada atividade. 0 planejamento de cada detalhe do trabalho envolvido gera um sentimento de segurança para aquele que está disposto a realizar tal atividade.

Um estudo do perfil do voluntário é imprescindível, uma vez que quanto mais a Organização conhecer aqueles que irão oferecer auxílio nas atividades, maior a chance de efetividade e maiores as chances da aproximação das expectativas e necessidades tanto da instituição como dos voluntários. Isso é nítido no gráfico abaixo (Figura ), que mostra que $55,1 \%$ dos estudantes entrevistados não retornariam à sua cidade natal sem finalizar o período de trabalho voluntário, ou seja, entender as necessidades e anseios do voluntário é o objetivo central, a fim de reduzir essa porcentagem de desistência da atividade.

Figura 7. Respostas à questão: Em caso de dificuldade enfrentada você cogitaria retornar à sua cidade natal sem finalizar o período de trabalho voluntário?

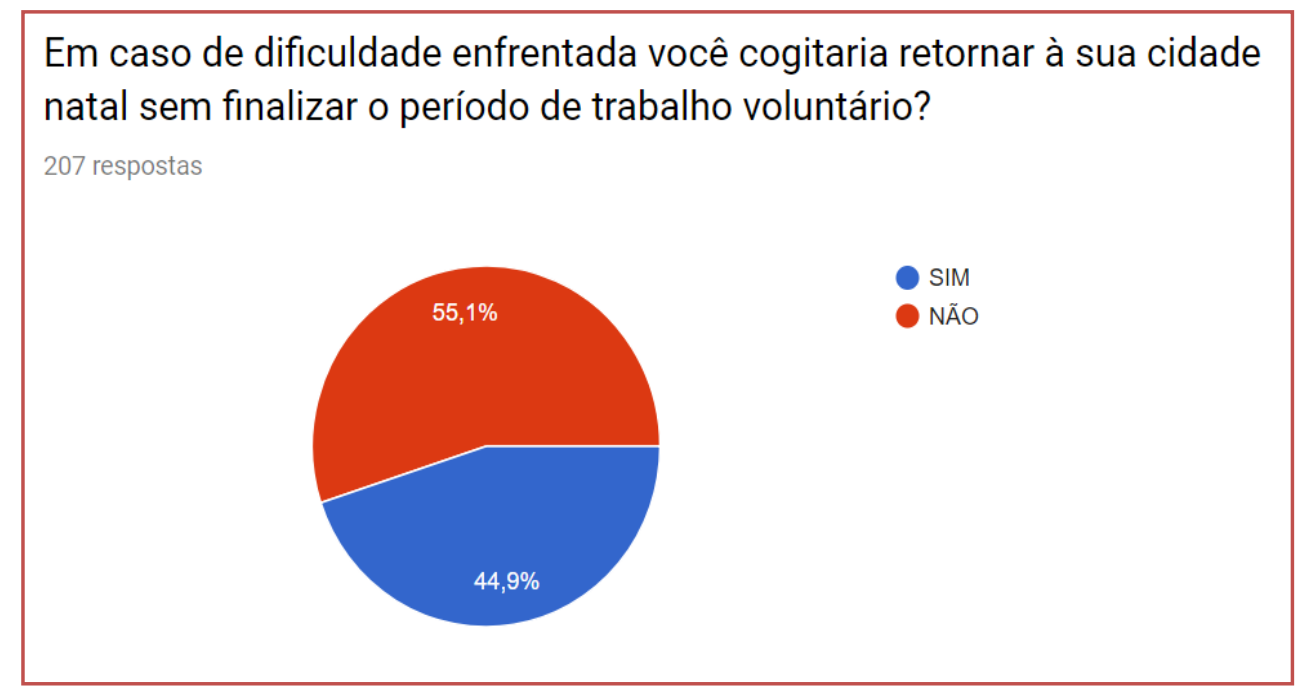

Fonte: Dados de Pesquisa

Além disso, entender a motivação do voluntário é essencial na criação de vínculos, para que a vida útil do voluntário não seja limitada apenas por interesses pessoais, mas que envolvam um propósito mais amplo. 
Atrair voluntários não é uma tarefa simples, trata-se de um obstáculo do Programa, uma vez que a doação do tempo requer um retorno de desenvolvimento do voluntário, para que assim, se fidelize em um vínculo a longo prazo. A Figura 8 evidencia exatamente esse possível vínculo criado, apenas 11,9\% do público entrevistado não tem interesse em continuar o vínculo com a Instituição que oferece o programa de trabalho voluntário.

Figura 8. Respostas à questão: Há interesse em continuar o vínculo com a Instituição que oferece o programa de trabalho voluntário?

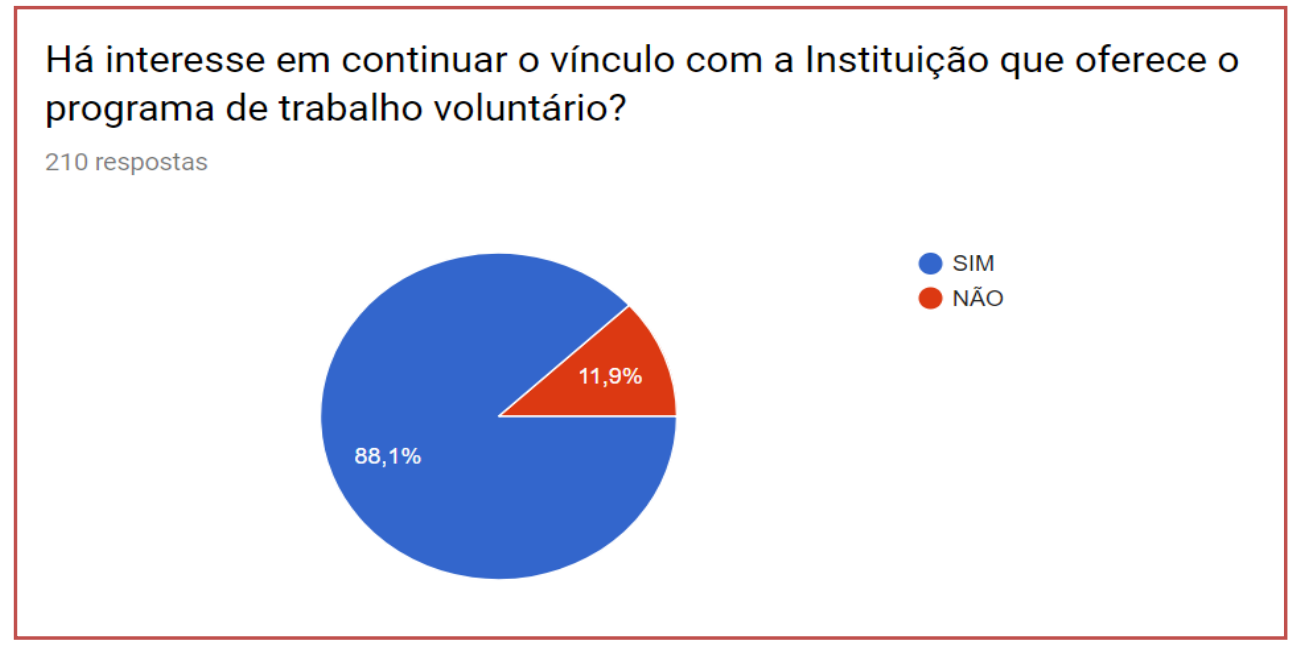

Fonte: Dados de Pesquisa

De acordo com a pesquisa realizada (Figura 9) os aspectos mais votados como fundamentais para o perfil do voluntário foram: empatia, tolerância, amor e amadurecimento. Resistência foi o menos votado pelos participantes.

O bem estar do outro é o foco central do voluntariado, mas o benefício acaba sendo mútuo, aquele que o realiza com certeza terá uma satisfação pessoal ao fim da ação.

O universitário em questão entende que se colocar no lugar do outro, entender a realidade imersa é fundamental para conseguir ajudá-lo com eficiência e por se tratar de uma experiência desafiadora, em ambiente totalmente fora da zona de conforto, ser tolerante é um pré-requisito. 0 amor naquilo que está fazendo está presente no dia a dia daquele que se dispõe a ajudar o outro, ou seja, ter conhecimento da realidade. 0 amadurecimento, por sua vez, envolve não só a postura do indivíduo durante a atividade, mas a consequência e aquilo que será colhido após o término da ação.

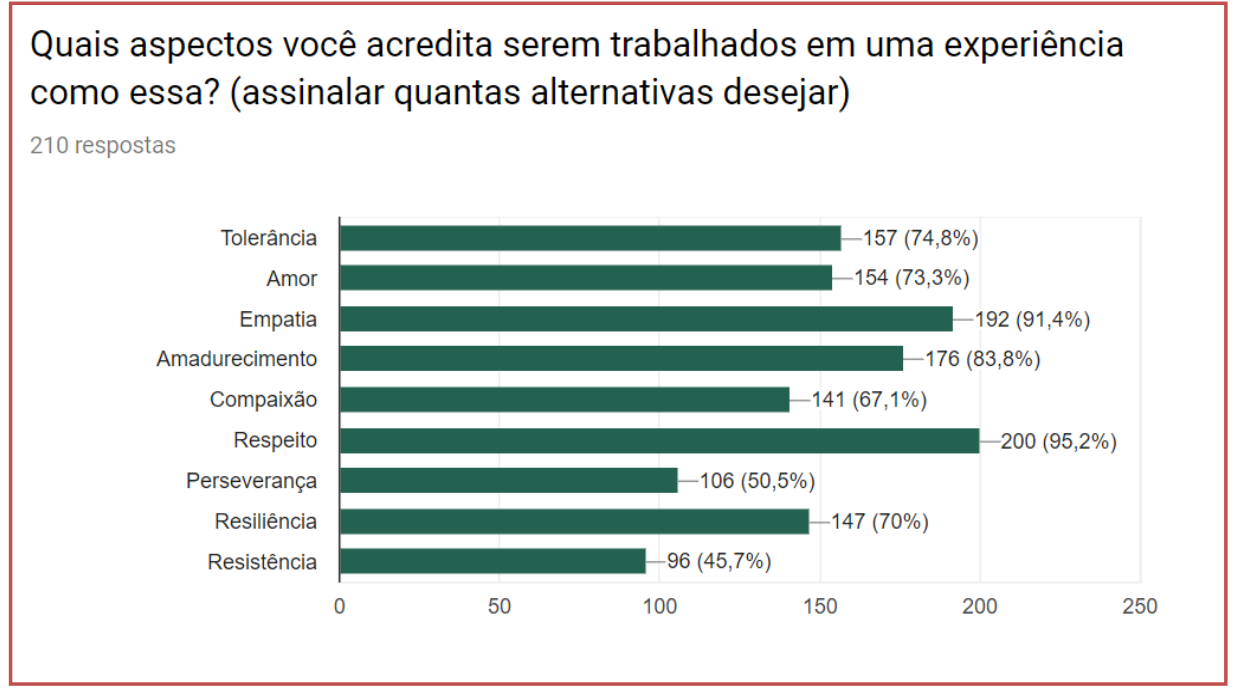

Figura 9. Respostas à questão: Quais aspectos você acredita serem trabalhados em uma experiência como essa? 
Fonte: Dados de Pesquisa

Em uma pergunta da pesquisa realizada, cinco aspectos foram expostos para determinaçao daquilo que apresenta maior importância no momento de realização da atividade voluntária de longa duração. Mostrase como ponto fundamental (Figura 10) que para a realização de trabalho voluntário em outro Estado o oferecimento de acomodação e alimentação durante as atividades.

Figura 10. Respostas à questão: 0 que você considera fundamental para fazer um trabalho voluntário com duração superior a 7 dias?

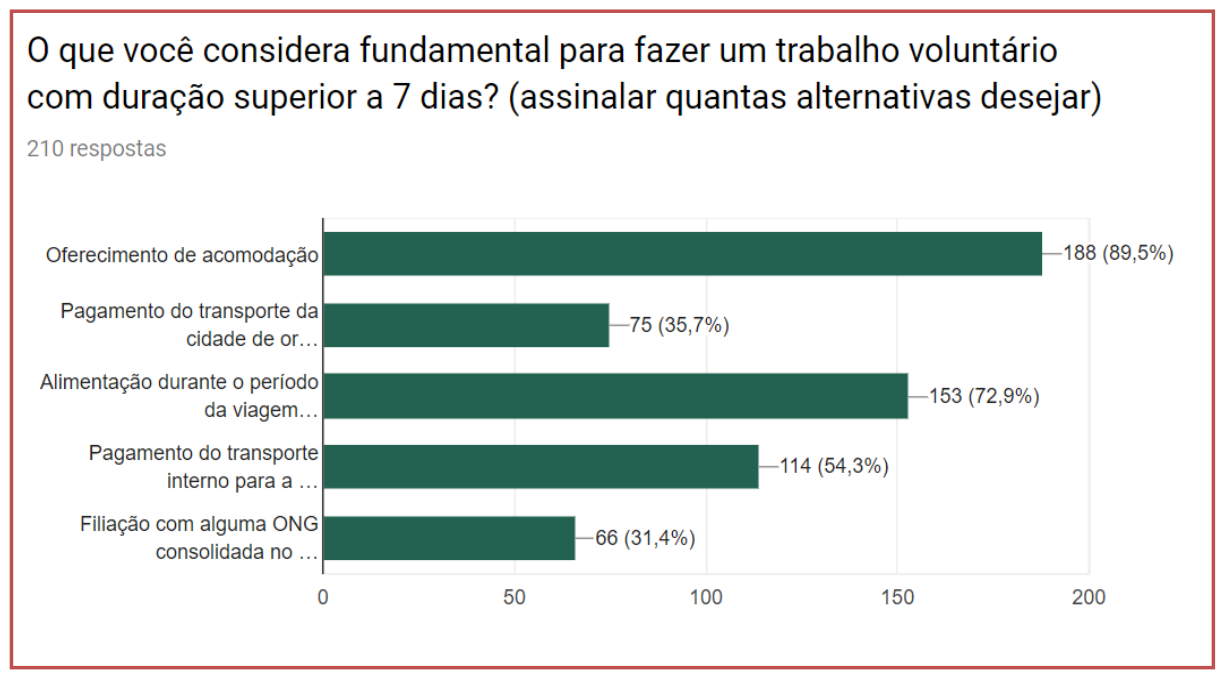

Fonte: Dados de Pesquisa

Analisando de maneira mais minuciosa a Figura 10, vemos que apenas 1,4\% daqueles que disseram já ter feito trabalho voluntário não fariam em qualquer Estado do país, dessa forma, temos um cenário favorável para implementação do Programa de voluntariado, há um nicho de oportunidade grande.

Como forma de ilustrar a viabilidade do Programa de Voluntariado no meio universitário, busca-se exemplo de pessoas que se disponibilizaram para ter essa experiência de vida e em contato com uma ONG, foi possível obter o relato completo de uma viagem na qual duas estudantes da Unicamp, dos cursos de Administração e Medicina, se voluntariaram para participar do projeto Valores da Amazônia, com visita a campo no Acre. $\mathrm{O}$ artigo completo que consta no site da ONG e no Apêndice do presente trabalho.

Por meio desse relato, é possível notar a importância da transparência de objetivos tanto da Instituição como das voluntárias. 0 trabalho obteve um resultado excelente pela adequação do cronograma, das partes envolvidas, da clareza na comunicação e comprometimento. Com um planejamento, é possível tornar realidade um trabalho aparentemente difícil de ser realizado.

Um artigo como esse traz segurança para aqueles que tem o interesse em realizar uma atividade semelhante. Os registros fotográfico e escrito são importantes para uma possível sucessão de atividades, para que o trabalho realizado possa ser usado como estudo futuro e inspiração para a realização de demais atividades. Tal experiência ganha espaço para ser divulgada, analisada, aperfeiçoada, passando a fazer parte de uma base de dados, disponível para todos aqueles que desejam ter conhecimento das etapas, dificuldades, conquistas, impactos e resultados do projeto.

\section{CONCLUSÃO}

0 meio universitário é um ambiente extremamente rico em diversidade, seja comportamental, nos valores, crenças, escolha sexual, ou demográfica, como faixa etária, renda, formação educacional. E isso o torna favorável para a implementação de projetos das mais diversas áreas, uma vez que a chance de aceitação é grande.

É na vivência universitária, que os alunos buscam ter experiências das mais diversas como forma de desenvolvimento pessoal e profissional. 0 contato com pessoas de diferentes classes sociais, faixa etária e 
opiniões distintas instigam o indivíduo a cada vez querer conhecer mais, como forma de moldar as próprias crenças e valores.

Além das vivências acadêmicas, que dizem respeito a pesquisa por exemplo, há o engajamento em atividades esportivas, participação de organizações estudantis, seja para defender os direitos dos estudantes ou para organizar esportes e eventos. Das organizações, muitas estimulam ações voluntárias, estabelecem o contato dos alunos com a comunidade local, em ações pontuais ou duradouras. Tais acontecimentos, podem ser vistos como estímulo para o desenvolvimento de um perfil altruísta, de ajuda ao próximo, cujo benefício é mútuo. 0 intuito, muitas vezes, é estimular que o indivíduo continue a participar de iniciativas voluntárias, mesmo fora do ambiente universitário.

É nesse contexto que a adesão a iniciativas voluntárias diferentes do convencional é ampla. Os universitários buscam nas atividades um objetivo pessoal ou profissional, realizam esse tipo de ação como forma de retribuir a cidade que estão morando tudo aquilo que ela oferece, isso gera um benefício mútuo de crescimento pessoal e ajuda ao próximo, que se estende à cidade vizinha, ao Estado, ao país inteiro e até a outros países.

É possível observar a amplitude e abrangência dos projetos desenvolvidos, sejam eles de causa social ou ambiental; os alunos se empenham para que tenham experiências das mais variadas ao longo da vida acadêmica abrindo espaço para um Programa de Voluntariado bem sucedido.

De acordo com a pesquisa realizada, a maioria dos universitários exige que sejam oferecidas alimentação e acomodação durante o período da ação, visto que a durabilidade é superior a um dia e que estão distantes da cidade onde residem.

Uma questão a ser discutida, é o retorno dos voluntários em caso de alguma dificuldade. Mais da metade daqueles que já realizaram trabalho voluntário pelo menos uma vez na vida, retornariam à sua cidade. Isso deve ser claramente esclarecido e conversado em encontros que antecedem à atividade para que não hajam complicações tanto para a Instituição responsável, quanto para o voluntário. Por mais que seja feito um planejamento, os imprevistos acontecem e acabam por alterar aquilo que estava previsto.

O perfil do voluntário deve ser estabelecido com base no projeto específico em questão. Trata-se de um fator limitante e possivelmente excludente, uma vez que a Instituição precisa garantir a efetividade do trabalho desenvolvido. Mas para isso, é necessário que seja feito um levantamento de quais atividades serão desenvolvidas ao longo da ação e análise de tudo aquilo que envolve o sucesso da atividade, se será preciso encontrar voluntários de alguma área específica, por exemplo alguém que faça Medicina para realização de um levantamento de dados quanto à saúde da comunidade em questão.

Diante dos objetivos específicos, é importante ressaltar as limitações do presente trabalho. A especificidade das pessoas que responderam a pesquisa gera uma análise focalizada, que pode ou não ser aplicada a outros meios, o foco em uma ação voluntária duradoura se difere da ações pontuais, requer um comprometimento mais elevado e a localidade distinta da de residência do voluntário, que acaba por envolver aspectos financeiros de deslocamento e disponibilidade de datas.

O objeto de estudo foi uma parcela dos estudantes de faculdades públicas e privadas de uma área do interior do Estado de São Paulo, dessa forma, não pode se garantir que a generalização de tal percepção para além do público em foco seja completamente viável. Sem dúvida há alteração dos resultados em caso de mudança de Estado e/ou Universidade. Isso se deve ao fato da realidade se alterar e por mais que o objetivo seja comum, há mudanças comportamentais, culturais e de crenças.

Para uma atividade voluntária pontual, certamente seriam obtidas diferentes conclusões a respeito da percepção de um Programa de Voluntariado no meio universitário. 0 foco foi justamente estudar a viabilidade de uma ação prolongada, extensa e que demanda uma disponibilidade de deslocamento do voluntário.

Além disso, devem ser considerados fatores instáveis para a efetivação da atividade, tais como mudanças climáticas da região em questão, possíveis conflitos étnicos e recursos disponíveis para apoio.

Dialogar a respeito do preparo, da ação em si e dos resultados obtidos tem-se como uma importante ferramenta para reconstruir e ressignificar, a troca de impressões por parte dos voluntários e da Instituição possibilita a criação de uma nova visão, de ideias aperfeiçoadas e de uma constante melhora para as atividades seguintes. 
O reconhecimento do trabalho de cada um é fundamental para valorizar e estimular a participação de cada membro envolvido, promovendo o comprometimento ainda maior e o engajamento em atividades futuras afim de perpetuar uma ação de tamanho impacto.

Sendo assim, tem-se que a percepção de um programa de voluntariado no meio universitário é extremamente positiva devido ao nicho de oportunidade encontrado no contexto estudado. Aliar o desejo de mudança e de impacto na sociedade com a necessidade de auxílio das organizações é como achar a resposta de uma equação matemática, a solução fica evidente quando se realiza um estudo minucioso de todas as variáveis envolvidas para atingir o objetivo em questão. Trata-se de um comprometimento, uma responsabilidade social para trazer melhorias ao mundo que vivemos e esse trabalho só é eficaz quando colaborativo e contínuo.

\section{REFERÊNCIAS}

[1] AZEVEDO, Debora. - Voluntariado corporativo e motivações para o trabalho voluntário. Revista Produção Online, v. 7, n. 4,2008

[2] BLUNE, Bruno André; MARMENTINI, Gabriel - ONGs: o que são e qual sua relevância? - Disponível em: http://www.politize.com.br/ong-o-que-e/ - Acesso em: 21 de Abril de 2018.

[3] CARDoso, Fernando Henrique - Seja um voluntário, Leis - Disponível em: http://voluntarios.com.br/leis.htm Acesso em 16 de Maio de 2018.

[4] CAVALCANTE, Carlos Eduardo. - Motivação no trabalho voluntário: delineamento de estudos no Brasil. Estudos do CEPE, p. 161-182, 2013.

[5] CERVO, Amado L.; BERVIAN, Pedro A.; SILVA, Roberto - Metodologia científica. 6ed. São Paulo: Pearson Prentice Hall, 2007.

[6] CONSTITUIÇÃo BRASILEIRA, Lei Federal no 9.608 e do Decreto oㅜ 2.536. Acesso em 13 de Maio de 2018.

[7] CORULlón, Mónica. - Trabalho Voluntário - Publicado pelo Conselho da Comunidade Solidária, 1996 - Disponível em:

http://www.espiritualidades.com.br/Artigos/C_autores/CORULLON_Monica_tit_Trabalho_Voluntario_Manual.ht m. Acesso em 10 de Julho de 2018.

[8] FERREIRA, Marisa; PROENÇA, Teresa; PROENÇA, João F. - As motivações no trabalho voluntário. Revista Portuguesa e Brasileira de Gestão, v. 7, n. 3, p. 43-53, 2008.

[9] JUNQUEIRA, Luciano A. Prates. - Voluntariado e a Gestão das Políticas Sociais - São Paulo: Editora Futura, 2002. 390p.

[10] LANDIM, Leilah; SCALON, Maria Celi. - Doações e trabalho voluntário no Brasil: uma pesquisa. - Rio de Janeiro: Viveiros de Castro Editora, 2000.

[11] MARCONI, Marina de Andrade; LAKATOS, Eva Maria. - Metodologia do Trabalho Científico. 7ed. São Paulo: Atlas, 2012.

[12] MOUTINHO, Wilson Teixeira - Sociedade e Sociologia - Disponível em: https://www.coladaweb.com/sociologia/sociedade. Acesso em: 03 de Agosto de 2018.

[13] ORGANIZAÇÃO DAS NAÇOES UNIDAS (ONU) - Disponível em: https://nacoesunidas.org/. Acesso em: 08 de Agosto de 2018.

[14] PENA, Rodolfo - Objetivos do Milênio - Disponível em: https://alunosonline.uol.com.br/geografia/objetivosmilenio.html. Acesso em: 01 de Maio de 2018.

[15] SILVEIRA, Ricardo - Lei 9.790/99 - Lei 13.019/14 - Parceiros Voluntários: IBGE calcula participação do terceiro setor - Disponível em: http://www.parceirosvoluntarios.org.br/ibge-calcula-participacao-economica-doterceiro-setor/ - Acesso em: 01 de Abril de 2018.

[16] SOBOLH, Telma e WIDMAN, Simon. - Voluntariado, a possibilidade da esperança - Cenário do Trabalho Voluntário no Brasil - São Paulo: Editora Voluntários Einstein, 2011.

[17] TACHIZAWA, Takeshy. - Organizações Não Governamentais e Terceiro Setor - Criação de ONGs e Estratégias de Atuação - São Paulo: Atlas Editora, 2014.

[18] TOZZI, José Alberto. - S.O.S da ONG - São Paulo: Gente, 2015. 


\section{ANEXO I}

\section{Questionário usado na pesquisa}

1. Você já fez trabalho voluntário com durabilidade superior a três dias consecutivos?

( ) $\operatorname{Sim}$

( ) Não

2.Já realizou trabalho voluntário em outro Estado?

( ) $\operatorname{Sim}$

( ) Não

3.Há interesse por trabalho voluntário de qual causa?

( ) Social

( ) Ambiental

( ) Ambas

4.Você realizaria trabalho voluntário em qualquer Estado do Brasil?

( ) $\mathrm{Sim}$

( ) Não

5.Pra você, o objetivo de um trabalho voluntário de maior extensão tem como finalidade alcance de curto ou longo prazo?

( ) Curto

( ) Longo

6.Há interesse em continuar o vínculo com a Instituição que oferece o programa de trabalho voluntário?

( ) $\operatorname{Sim}$

( ) Não

7.Você acredita que o trabalho seja mais eficiente em um grupo de pessoas conhecidas?

( ) $\mathrm{Sim}$

( ) Não

8.Tem como pré requisito estar com pessoas conhecidas na realização do trabalho voluntário?

( ) $\operatorname{Sim}$

( ) Não

9.Em caso de dificuldade enfrentada você cogitaria retornar à sua cidade natal sem finalizar o período de trabalho voluntário?

( ) $\mathrm{Sim}$

( ) Não

10.Na sua visão, qual o tempo ideal de atividades em um dia?

( ) $1 \mathrm{~h}$

( ) $3 h$

( ) $6 \mathrm{~h}$

( ) $8 \mathrm{~h}$

11.Você sente a necessidade de conhecer previamente os companheiros de trabalho voluntário? Uma vez que fará parte de um grupo de pessoas que não fazem parte do seu meio.

( ) $\operatorname{Sim}$ 


\section{( ) Não}

12.Quais aspectos você acredita serem trabalhados em uma experiência como essa? (assinalar quantas alternativas desejar)
( ) Tolerância
( ) Amor
( ) Empatia
( ) Amadurecimento
( ) Compaixão
( ) Respeito
( ) Perseverança
( ) Resiliência
( ) Resistência

13.0 que você considera fundamental para fazer um trabalho voluntário com duração superior a 7 dias? (assinalar quantas alternativas desejar)

( ) Oferecimento de acomodação

( ) Pagamento do transporte da cidade origem ao local de trabalho

( ) Alimentação durante o período da atividade voluntária

( ) Pagamento do transporte interno para a realização das atividades

( ) Filiação com alguma ONG consolidada no país 


\section{Capítulo 3}

\section{Educação Social - Pedagogia Social: Origem, conceito e contradições com a Pedagogia Escolar}

\section{Micheline Medeiros dos Santos Sant'Anna \\ Beatriz Rosália Gomes Xavier Flandoli}

Resumo: Num país calcado pela desigualdade, vários fatores concorrem para a exclusão de grande parcela da população que continua tendo dificuldade de acesso à escolarização formal. Face à dificuldade de acesso dos indivíduos que vivem em situação de vulnerabilidade econômica e social, a Pedagogia Social surge como possibilidade de contribuir com processos educativos a populações vulneráveis que vêm sendo excluídas desses processos educacionais, pois além de ser considerada uma ciência inserida na Pedagogia, ela pode se apresentar tanto em espaços de educação formal quanto não formal, o que nos permite inferir que este tipo de educação se consolida na sobreposição de diversas práticas sociais. Neste sentido, este estudo tem como objetivo analisar as aproximações e/ou diferenças existentes entre a Pedagogia Social e a Pedagogia Escolar, numa perspectiva histórico cultural, e na tentativa de demonstrar as influências históricas que antecederam e promoveram o surgimento da Pedagogia Social e/ou Educação Social. Este trabalho se constitui como uma pesquisa bibliográfica, caracterizada como qualitativa, pois busca identificar os cruzamentos nas ações educativas, bem como as suas variações nos processos de ações pedagógicas. Pode-se concluir que a Pedagogia Social e Pedagogia Escolar possuem semelhanças e contradições, porém, ambas possuem o mesmo objetivo: a formação política com o desenvolvimento pleno do ser humano visando a transformação social do indivíduo, uma vez que no percurso que ambas participam atuando diretamente nas ações educativas, sejam elas em espaços denominados formal e não formal, permite a mudança da própria realidade de vida, possibilitando a construção de projetos de vida pessoal e social.

Palavras-chave: Pedagogia Social. Pedagogia Escolar. Educação formal e não formal. 


\section{O INÍCIO DA CAMINHADA}

A origem da Pedagogia Social está vinculada à vários fatores que contribuíram e foram primordiais para a sua execução, pois além de ser considerada uma ciência e que está inserida na Pedagogia como um todo, ela pode se apresentar tanto nos espaços de educação formal quanto não formal, o que nos permite inferir que este tipo de educação se consolida na sobreposição de diversas práticas sociais, e que se desenvolve nos mais variados contextos sociais. Sendo as suas intervenções práticas definidas como Educação Social.

Estas práticas sociais educativas podem ocorrer em diferentes tempos e espaços, bem como se apresentarem nos ambientes da Educação Escolar. Neste sentido, este artigo tem como objetivo analisar as aproximações e/ou diferenças existentes entre a Pedagogia Social e a Pedagogia Escolar, numa tentativa de explicar se ambas podem se apresentar de maneira simultânea, harmoniosa, conflituosa e/ou em cooperação? Desta forma, esta investigação se baseia numa perspectiva histórico cultural, na tentativa de demonstrar os contextos históricos que antecederam e promoveram o advento da Pedagogia Social Educação Social.

0 artigo se constitui como uma pesquisa bibliográfica, uma vez que serão analisados alguns estudos científicos no que diz respeito a esta temática (GIL, 1999), desenvolvidos por alguns teóricos (PAIVA, 2015; CALIMAN, 2010; GADOTTI, 2013; GRACIANI, 2014) que discutem vários contextos sobre as ações da Pedagogia Social e da Pedagogia Escolar, ambas da área do conhecimento da Educação. Este estudo ainda se configura como uma pesquisa qualitativa, pois busca identificar os cruzamentos nas ações educativas, bem como as suas variações dos processos de ações pedagógicas, na tentativa de promover a socialização e integração do indivíduo ao seu meio social (LUDKE; ANDRÉ, 1986).

Antes de iniciar este estudo científico, é importante salientar que durante as aulas da disciplina de Educação Social oferecida no Programa de Pós-Graduação em Educação da Universidade Federal de Mato Grosso do Sul - Campus do Pantanal, foram surgindo várias dúvidas sobre esta temática, que resultaram nesta investigação como forma de sanar e/ou entender a dinâmica de suas ações, com os seguintes questionamentos: o que podemos definir como Educação Social, e como surgiu? O que a difere da Educação Escolar? Por que há questionamentos sobre se as ações sociais só ocorrem em espaço de Educação não formal? Qual a diferença entre Educação formal e não formal? Este tipo de educação permite a "consciência em si" do indivíduo?

$\mathrm{Na}$ tentativa de responder aos questionamentos anteriores, bem como de elucidar sobre a origem, definição, legalização e funcionamento da Educação Social, dividimos este estudo em 3 partes. Na primeira parte será exposto, logo após a esta introdução, um breve histórico sobre a Educação Social - Pedagogia Social, bem como alguns conceitos importantes, levando em consideração que se trata de uma educação em construção; no segundo momento, serão elencados os direitos estabelecidos em lei em alguns documentos oficiais que permitem a oferta da Educação a todo e qualquer cidadão; em seguida, na terceira e última parte, iremos tecer sobre quais são as críticas sobre as ações sociais educativas da Educação Social.

Nestes termos, entender como se materializa o universo educativo presentes nesta dinâmica pedagógica do processo de aprendizagem do indivíduo, faz-se necessário saber que a nossa educação advém inicialmente no nosso ambiente familiar, e, portanto, o respeito à cultura de mundo de cada um que esteja inserido num determinado contexto social, apresentando a sua realidade de vida, envolvendo vários aspectos culturais, psíquicos e econômicos, é primordial. Na medida que o indivíduo vai se desenvolvendo, esta educação inicial se estende ao seu meio de convivência social no processo de aquisição da cultura deste meio, e posteriormente, numa fase concomitante ou não com a anterior, na maioria das vezes, o mesmo se encontra no período de aprendizagem da fase de educação escolar.

Porém, temos o conhecimento de que nem sempre isso ocorre linearmente e/ou gradativamente, uma vez que, apesar do acesso à educação ser para todos, conforme estabelecido em lei, existem vários fatores que podem excluir socialmente aos que vivem à margem da sociedade, ou seja, numa situação de vulnerabilidade social. É nesta situação socioeconômica que a maior parte da população mundial se encontra: excluídos socialmente e desprovidos de seus direitos.

Como forma de suprir a essas necessidades da humanidade, após acontecimentos históricos que contribuíram para se agravar ainda mais esta situação, que se iniciam as ações sociais em prol dos pertencentes as classes desfavorecidas e que precisam de apoio para sobreviver em meio a tantas atrocidades, promovendo intervenções de práticas educativas sociais da Pedagogia Social e que serviram de apoio para a reestruturação da população. 


\section{0 QUE ESTÁ REGULAMENTADO EM LEI QUE PERMITE O DIREITO À EDUCAÇÃO?}

Para promover a instrução e o desenvolvimento pleno do indivíduo, permitindo que o mesmo seja integrado à sociedade, requer o comprometimento do Estado, através das políticas públicas que tornam viáveis as ações educativas, sendo esta ação um direito adquirido e proporcionado pelas instituições sociais responsáveis. Porém, vivemos uma época em que os direitos adquiridos estão sendo subtraídos, e, portanto, impedindo que os mesmos sejam repassados as gerações posteriores.

Sabendo que os direitos do homem nascem conforme o desenvolvimento histórico e cultural da humanidade, bem como para servir as necessidades do ser humano, temos a ciência de que estas garantias não surgem de uma só vez, e sim na proporção e atendimento as carências da sociedade, até porque os direitos sofrem variações de acordo com o período histórico. Além disso, os direitos se apresentam de forma heterogênea, ou seja, são diferentes e ainda podem divergi entre si. Portanto, para cada fase de nossas vidas, e à medida que surgem novas necessidades para vivermos harmoniosamente em sociedade, são oferecidas garantias que contribuem para o nosso progresso (BOBBIO, 1992).

Nestes termos, esta garantia aos direitos do homem foi fortalecida logo após o final da Segunda Guerra Mundial, que sucederam vários fenômenos sociais, possibilitando o reconhecimento dos direitos sociais da humanidade. Podemos perceber que o crescimento dos direitos sociais está diretamente relacionado à transformação da sociedade, uma vez que as inovações técnicas e o progresso econômico fazem surgir novas necessidades sociais. Diante disto, o Estado admite a universalização dos direitos concebidos através da Declaração Universal de Direitos Humanos, bem como se fez necessário à sua intervenção como garantia destes direitos sociais. A Declaração em seu artigo $26^{\circ}$ estabelece que

1.Todo ser humano tem direito à instrução. A instrução será gratuita, pelo menos nos graus elementares e fundamentais. A instrução elementar será obrigatória. [...] 2.A instrução será orientada no sentido do pleno desenvolvimento da personalidade humana e do fortalecimento do respeito pelos direitos humanos e pelas liberdades fundamentais. A instrução promoverá a compreensão, a tolerância e a amizade entre todas as nações e grupos raciais e religiosos [...] (ONU, 1948, p. 14).

Nesta perspectiva, somado ao direito da instrução, existem também mais benefícios expressos nesta Declaração que devem ser atribuídos a todo e qualquer cidadão, como forma de promover a formação política e como prática de liberdade desenvolvendo a chamada "consciência em si", o que além de assegurar os direitos básicos, proporciona o exercício da cidadania (FREIRE, 1987). Portanto, na tentativa de favorecer ao desenvolvimento de suas capacidades, a Declaração (ONU, 1948, p. 13) estabelece em seu artigo $25^{\circ}$ que todo ser humano

[...] tem direito a um padrão de vida capaz de assegurar-lhe, e a sua família, saúde e bem-estar, inclusive alimentação, vestuário, habitação, cuidados médicos e os serviços sociais indispensáveis, e direito à segurança em caso de desemprego, doença, invalidez, viuvez, velhice ou outros casos de perda dos meios de subsistência em circunstâncias fora de seu controle.

Por outro lado, para que seja possível a garantia desses direitos, sejam eles proporcionados em instituições que oferecem a educação formal ou não formal ${ }^{1}$, devem existir movimentos sociais na sociedade, na tentativa de legitimar o que está estabelecido em lei e que deve ser preservado. Porém, o que se percebe é que essa garantia vem sendo articulada de maneira arbitrária, isto é, as ações do Estado com o intuito ínfimo de assegurar a execução deste direito, sendo ele para a instrução ou para a concessão de direitos básicos e fundamentais para a sobrevivência do indivíduo, o que transparece é que existem "limitações" nas funções do Estado, uma vez que tais funções oferecem garantias mínimas ao que se encontra previsto em lei, o chamado Estado mínimo (BOBBIO, 2010).

${ }^{1}$ A Educação não formal pode ser definida como toda e qualquer instrução apreendida na troca de experiências em espaços coletivos no cotidiano do ser humano. Já a Educação formal é aquela desenvolvida em espaços escolares, ou seja, em instituições sociais com conteúdos previamente demarcados (Gohn, 2006). Porém, Gadotti (2013) determina que se deve definir a Educação não formal como ela se apresenta, pela sua singularidade e não em contradição com a Educação formal. 
Essas limitações de ações, inviabilidade ou o não interesse na aplicabilidade da lei, principalmente quanto aos direitos sociais, sofrem de grande defasagem entre a norma e a sua efetiva aplicação, que deverá ser quantificada e reduzida pelos sociólogos do direito. Porém, além de haver grande esforço das forças políticas para a superação desse problema, ocorrem movimentos sociais e políticos que lutam pela legitimação desses direitos. A Constituição Federal promulgada em 1988 é um exemplo deste empenho. Sendo assim, o direito à educação na Constituição Federal de 1988 é estabelecido tanto em seu artigo 6o, que dispõe a educação como um direito social, quanto em seu artigo $205^{\circ}$ que institui a educação como direito de todos os seres e que este direito deve ser atribuído ao Estado e à família (BRASIL, 1988).

Entretanto, infelizmente é visível a violação desse direito à instrução para com aqueles que se encontram em situação de vulnerabilidade social. Pois, de acordo com o que se encontra assegurado em lei, os direitos básicos de todo e qualquer cidadão, vêm sendo violados diariamente. 0 artigo $227^{\circ}$ da Constituição

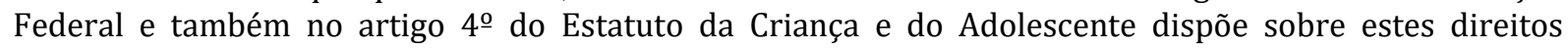
básicos:

É dever da família, da sociedade e do Estado assegurar à criança, ao adolescente e ao jovem, com absoluta prioridade, o direito à vida, à saúde, à alimentação, à educação, ao lazer, à profissionalização, à cultura, à dignidade, ao respeito, à liberdade e à convivência familiar e comunitária, além de colocá-los a salvo de toda forma de negligência, discriminação, exploração, violência, crueldade e opressão (BRASIL, 1988).

0 direito e acesso à educação oferece a oportunidade para o cidadão, pertencente a qualquer classe social, a oportunidade de transformação social, política e cultural através da sua conscientização crítica possibilitada pela oferta de uma formação política, seja em seus estudos seja em seus aprendizados no convívio com o seu grupo social. Esta formação torna possível a reestruturação familiar, educacional e profissional, bem como possibilita que o indivíduo em qualquer fase de sua vida, tenha a oportunidade de construir seu projeto de vida pessoal e social. Pois, conforme assegura o artigo $4^{\circ}$ do Estatuto da Criança e do Adolescente,

É dever da família, da comunidade, da sociedade em geral e do poder público assegurar, com absoluta prioridade, a efetivação dos direitos referentes à vida, à saúde, à alimentação, à educação, ao esporte, ao lazer, à profissionalização, à cultura, à dignidade, ao respeito, à liberdade e à convivência familiar e comunitária. (BRASIL, 1990, p. 23).

Em um outro documento oficial brasileiro que define e regulamenta todo o sistema educacional brasileiro, ou seja, expressa os direitos e deveres relacionados à educação básica até o ensino superior, seja ele em instituições públicas ou privadas, criada com base nos princípios presentes na Constituição Federal, reafirma o direito à educação ao cidadão comum. Esta lei é definida como Lei de Diretrizes e Bases da Educação Nacional - LDB, Lei no 9394/96, e em seu artigo 22o retrata o direito à educação e especifica sobre desenvolvimento do indivíduo, dispondo que "A educação básica tem por finalidades desenvolver o educando, assegurar-lhe a formação comum indispensável para o exercício da cidadania [...]” (BRASIL, 1996).

Portanto, podemos observar e refletir, que tudo o que foi exposto anteriormente, sobre o que dispõe os documentos oficiais referente ao direito à educação, como forma de promover o desenvolvimento pleno do indivíduo, permitindo assim o exercício da sua cidadania, bem como o desenvolvimento das suas capacidades superiores, possibilitando uma progressão nas suas habilidades/potencialidades, demonstra que não há um documento em específico que trata de forma segregada e/ou prioritária as várias maneiras de se oferecer uma educação. 0 que existe

Para facilitar a reflexão sobre a explanação anterior, não fica nítido nos documentos que deva existir um tipo de Educação Social num determinado ambiente e um tipo de Educação Escolar em outro. Devido as várias transformações sociais, econômicas e culturais, ocorridas em determinadas épocas históricas para suprir as necessidades humanas, a educação foi sendo organizada para atender a interesses sociais e econômicos, com o intuito de facilitar as ações educativas no processo de aprendizagem em cada fase do indivíduo. No entanto, não é porque a legislação se apresenta desta forma que devemos fazer alusão a um movimento contrário e tratar a Educação Social, que se encontra em construção, como uma educação que veio oferecer apenas assistência social as classes que se encontram em situação de vulnerabilidade social. 
Isso não quer dizer também que a ação social que se oferece em espaços de educação não formal, não possa acontecer concomitante com a ação educativa que encontramos nas instituições escolares. Esta ação pode vim a ser concedida agregada a temas transversais, de maneira interdisciplinar ou multidisciplinar, bem como pode ser inserida nos currículos definidos pelos parâmetros curriculares nacionais, dispostos nos conteúdos científicos. Não queremos aqui contestar a forma como funciona o processo de aprendizagem do indivíduo, e sim o porquê desta segregação entre Educação Social e Educação Escolar, uma vez que na nossa visão as duas podem se complementar de maneira harmoniosa, sem discriminar as ações sociais que ocorrem nos mais variados ambientes educacionais.

\section{BREVE HISTÓRICO SOBRE A EDUCAÇÃO SOCIAL/PEDAGOGIA SOCIAL E ALGUMAS CONSIDERAÇÕES SOBRE A SUA ORIGEM E CONCEITOS IMPORTANTES}

Entendendo que a Educação Social se apresenta como uma intervenção de práticas educativas que faz parte do contexto da Pedagogia Social, nada mais coerente que buscarmos a origem desta ciência social que tem como objetivo principal trabalhar o social através do ato educativo. Apesar de se apresentar como uma ciência em construção, a Pedagogia Social tem a sua origem na Alemanha, no século XX, logo após a $2^{\text {a }}$ Guerra Mundial, que gerou consequências de grande proporção, causando sofrimentos sociais, como: aumento do desemprego, da marginalidade, da desigualdade social e econômica, entre outros problemas sociais.

No nível mundial, a Pedagogia Social surge primeiro na Alemanha, e entre os teóricos alemãs que mais se destacaram com estudos relacionados a esta temática, podemos apontar o filósofo alemão Paul Nartop, que foi o pioneiro nos estudos desta ciência e contribuiu incisivamente com a sua difusão em alguns países da Europa, como Espanha, Itália, Portugal e Finlândia (PAIVA, 2015; CALIMAN, 2010; GADOTTI, 2013). Ele consegue compreender que ao mesmo tempo que reconhecemos que a educação é uma condição social, ela também influencia diretamente na forma como organizamos a nossa realidade de vida (GADOTTI, 2013).

Paiva (2015) retrata em seu livro intitulado "Caminhos do Educador Social no Brasil" que a Pedagogia Social sofre mutações em suas ações conforme a cultura existente naquele país em que ela se apresenta, por exemplo: na Itália, a Pedagogia Social proporciona a inclusão cultural e social de indivíduos marginalizados através da animação sociocultural; já na Espanha as ações educativas são para atender as necessidades sociais do indivíduo, como: atenção à infância, adolescência, juventude, terceira idade, deficiente físico, etc. Isso possível por vários fatores, mas principalmente por esta ciência ainda se encontrar em construção e não possuir uma regulamentação da profissão.

Quando a Educação Social - Pedagogia Social surgiu no Brasil, neste período estava em funcionamento o processo educacional para erradicação do analfabetismo. Portanto, a Pedagogia Social além de sofrer influências das ideias de Paulo Freire, está fundamentada nas concepções da Educação Popular, uma vez que a sua ação educativa está atrelada ao "[...] conhecimento de mundo para sua transformação por meio de um processo educativo dialógico, rigoroso, intuitivo, imaginativo, comunitário, participativo e afetivo" (GRACIANI, 2014).

Paiva (2015) também defende a ideia de que "O diálogo é o ponto chave da Pedagogia Social". Pois, todo esse processo de aquisição do conhecimento através do diálogo, valoriza o cotidiano do indivíduo, respeitando as suas particularidades, o que possibilita uma construção histórica e cultural do indivíduo, contribuindo para a conscientização crítica deste ser.

Vale ressaltar que apesar de se apresentar ainda como um projeto de lei ${ }^{2}$ em tramitação no senado, a Educação Social se desenvolve num vasto campo de atuação, pois além de atender as situações de risco da sociedade, que se manifesta nas formas de pobreza, no consumo de drogas, marginalidade, entre outras, pode se mostrar também, e principalmente, em espaços de educação formal, através de intervenções educativas intencionais executados nas escolas.

E quando estas ações sociais educativas são executadas em espaços de educação formal, ou seja, nas escolas. Qual seriam as características destas ações? Respeitam as particularidades dos indivíduos? Seriam iguais as àquelas que acontecem fora das instituições formais? Qual seria o contexto destas ações? São dúvidas como estas que no cotidiano destas ações, muitos profissionais da área se perguntam, bem como 
alguns pensadores desta temática buscam para questionarem como poderiam executar determinadas práticas educativas sejam elas em espaços de educação formal e não formal, ou em ambas. Para Caliman (2006), existe uma diferença sim entre a Pedagogia Social e a Pedagogia Escolar, porém nada que impeça a sua ação de maneira efetiva, ou seja,

[...] a pedagogia social, se desenvolve dentro de instituições não formais de educação. É uma disciplina mais recente que a anterior. Nasce e se desenvolve de modo particular no século XIX como resposta às exigências da educação de crianças e adolescentes (mas também de adultos) que vivem em condições de marginalidade, de pobreza, de dificuldades na área social. Em geral essas pessoas não frequentam ou não puderam frequentar as instituições formais de educação. Mas não só: o objetivo da pedagogia social é o de agir sobre a prevenção e a recuperação das deficiências de socialização, e de modo especial lá onde as pessoas são vítimas da insatisfação das necessidades fundamentais. Podemos reafirmar, portanto, que no Brasil atual a Pedagogia Social vive um momento de grande fertilidade. É um momento de criatividade pedagógica mais que de sistematização dos conteúdos e dos métodos. Em outras palavras, mais que pedagogistas, temos no Brasil educadores que colaboram com o nascimento e o desenvolvimento de um know how com identidade própria, rica de intuição pedagógica e de conteúdos. Ao mesmo tempo nos damos conta de que é chegado o momento no qual precisamos sistematizar toda essa gama de conhecimentos pedagógicos para compreender melhor e interpretar a realidade e projetar intervenções educativas efetivas

Mas afinal, qual seria o objeto de estudo da Pedagogia Social? O objeto da Pedagogia Social é a Educação Social, o qual define o conteúdo dessa disciplina: a relação da educação com a sociedade. Com isso, é importante dizer que o campo de atuação do Educador Social atinge caminhos que em sua maioria não são trilhados pelo caminho de uma Educação Escolar. Caminhos complexos e que exigem um preparo e conhecimentos didáticos e científicos, e que ás vezes por falta de informação não há o reconhecimento de suas ações (PAIVA, 2015).

O não reconhecimento dos espaços que podem ser ocupados pelas ações sociais educativas da Educação Social, é comum nesta área. Existe um consenso que o tipo de espaço pode ser determinado conforme a ação executada, ou de acordo com sua estrutura e organização, entre outros. Porém, apesar da existência deste consenso, há definições importantes e que devem ser discutidas e abordadas sempre que houve necessidade, como tentativa de criar e/ou manter uma identidade profissional, tanto para os educandos, como e principalmente, para os educadores. Desta forma, Gadotti define que

a educação formal é representada principalmente pelas escolas e universidades. Ela depende de uma diretriz educacional centralizada como o currículo, com estruturas hierárquicas e burocráticas, determinadas em nível nacional, com órgãos fiscalizadores do Ministério da Educação. A educação não-formal é mais difusa, menos hierárquica e menos burocrática. Os programas de educação não-formal não precisam necessariamente seguir um sistema sequencial e hierárquico de "progressão". Podem ter duração variável, e podem, ou não, conceder certificados de aprendizagem (2013, p. 8).

Existem autores que definem a Educação formal e não formal como algo mais simplista, e ainda acrescenta outro tipo de Educação: a informal. GOHN, especifica que

[...] a educação formal é aquela desenvolvida nas escolas, com conteúdos previamente demarcados; a informal como aquela que os indivíduos aprendem durante seu processo de socialização - na família, bairro, clube, amigos etc., carregada de valores e culturas próprias, de pertencimento e sentimentos herdados: e a educação não-formal é aquela que se aprende "no mundo da vida", via os processos de compartilhamento de experiências, principalmente em espaços e ações coletivos cotidianas (2006, p. 29). 
Ambos os autores, conceitua a educação com suas variações, e se refletirmos sobre o espaço do ambiente onde ocorre essa ação educativa, esta poderia ou não seguir um padrão, uma sequência de atividades com regras e normas ou até mesmo quebrar estas regras, a cristalização de ideias previamente estipuladas para toda atividade a ser executada. Porém, apesar de sabermos que existe um currículo definido pelos parâmetros curriculares nacional e que deve ser seguido como uma diretriz, podemos seguir o caminho mais apropriado e que respeita a singularidade do indivíduo que se encontra no processo de aprendizagem.

E como respeitar as particularidades do indivíduo, ofertando atividades que o educador identifica como ideal para o seu desenvolvimento integral, se existem órgãos fiscalizadores no Ministério da Educação? Como isso seria possível? Através de práticas educativas que sejam ações humanizadas e que incorporam novos conhecimentos aos indivíduos, tornando o processo de aprendizado mais significativo. Cabe aqui um pensamento de Freire (1978, p. 79), onde ele expressa que "Ninguém educa ninguém, como tampouco ninguém se educa a si mesmo: os homens se educam em comunhão, mediatizados pelo mundo". Ou seja, o Educador será o mediador nas ações educativas, oferecendo novos conhecimentos que podem ser definidos como práticas sociais. 0 autor Oliveira, reconhece que as

Práticas sociais decorrem de e geram interações entre os indivíduos e entre eles e os ambientes, natural, social, cultural em que vivem. Desenvolvem-se 11 no interior de grupos, de instituições, com o propósito de produzir bens, transmitir valores, significados, ensinar a viver e a controlar o viver, enfim, manter a sobrevivência material e simbólica das sociedades humanas. (et al. 2009, p. 4).

Após demonstrar sobre como surgiu a Educação Social - Pedagogia Social e algumas particularidades do funcionamento dos espaços onde são executadas as ações sociais, seja ela no espaço de Educação formal ou não formal, buscamos então compreender o porquê que essas atividades dinâmicas desenvolvidas no interior desses espaços, ainda não conseguiram diminuir de maneira significativa os problemas sociais existentes em nossa sociedade, se ambos os espaços oferecem suporte para tal ação?

\section{AFINAL, QUAIS SÃO AS CRÍTICAS SOBRE AS AÇÕES SOCIAIS EDUCATIVAS DA EDUCAÇÃO SOCIAL?}

Conseguimos visualizar várias questões inerentes a essa busca incansável pela resolução de toda essa problemática nas questões sociais em nossa sociedade. A principal delas é a questão da desigualdade social, fruto da não aplicabilidade das condições básicas de sobrevivência que deveria ser oferecida como direito primordial, estabelecido em lei no artigo 227ํㅜ da Constituição Federal (BRASIL, 1988). Os problemas sociais que vêm sendo enfrentado em vários espaços educativos são recorrentes há décadas, bem como podemos inferir que a origem destas situações de risco, por vezes, é oriunda de muitos lares que sofrem com a ação denominada Estado mínimo.

Com o aumento dos conflitos sociais, o que consequentemente desenvolve questões como: desemprego, marginalidade, desigualdade social e econômica, drogas, violência doméstica e urbana, entre outros problemas sociais que além de alcançarem diversos contextos sociais, penetram as escolas por dentro e por foca, contribuindo para o avanço dessas "epidemias sociais"; tudo isso faz com que o direito adquirido se torne subjetivo e com isso este direito acaba não sendo oferecido e aplicado de maneira efetiva como estabelecido em lei. A partir daí, cria-se uma visão assistencialista da ação educativa social, o que a torna tendenciosa, resultando numa visão reducionista da Educação Social, dando uma maior visibilidade para as ações compensatórias do Estado.

Diante disto, reconhecer que a educação é uma condição social, um direito, e que ela influencia diretamente na maneira como organizamos a nossa vida, é aplausível e ao mesmo tempo frustrante, uma vez que nem sempre este direito é ofertado como se apresenta em lei. Porém, nem sempre todos conseguem visualizar que esta condição social é uma oportunidade para a mudança social do indivíduo, uma tentativa de transformação plena, deste ser destituído de seus direitos legítimos. Entretanto, essa mudança vai ocorrer dependendo da forma como a educação está sendo oferecida, uma vez que o mediador desta transformação, no caso o Educador Social deve possuir características singulares, próprio daquelas pessoas que acreditam no ser humano, independente da sua origem, e que, principalmente tenham a arte de encantar as pessoas que tanto necessitam desta transição na vida para uma fase melhor.

Existe um ponto importante e que devemos apresentar no contexto das críticas quanto as ações da Pedagogia Social a nível mundial: as mutações sofridas em suas ações, conforme a cultura existente no país 
em que ela se apresenta, pode contribuir incisivamente para a desconfiança de que esta ciência, por se encontrar em construção e não possuir uma regulamentação profissional, possibilita a incredulidade de que suas ações intencionais possam obter resultados contrários ao que se aspirava, seja no desenvolvimento de crianças, jovens e adultos, ou seja em ações comunitários com pessoas idosas, todas desprovidas de direito e em situação de vulnerabilidade social.

Existe um outro ponto importante a ser pontuado: as ações executadas na Educação Social requerem um aprendizado diário de conhecimentos específicos e que somente este profissional com sua a sensibilidade pedagógica, poderá intervir em ações através do diálogo, o qual é considerado como o ponto chave da Pedagogia Social. É através dele que se cria a possibilidade de aproximação com o indivíduo, respeitando as suas especificidades, bem como permite que o mesmo tenha autonomia para construir a sua história, bem como proporcionará o desenvolvimento da criticidade deste indivíduo. Porém, alguns teóricos contestam que não seria uma boa estratégia para educar o indivíduo, uma vez que este modelo de educação não prioriza ações educativas que promovam o aprendizado de conteúdos científicos, e, portanto, seria uma ação reducionista da Educação Social.

Observamos neste trabalho que a pedagogia social possui distanciamentos com relação as ações da pedagogia escolar por diversas razões. Em primeiro lugar, a educação social através de suas intervenções práticas consegue atender aos problemas apresentados pela educação escolar, na maioria das vezes. Porém, existe de forma enraizada na sociedade, a ideia de que a educação escolar acontece na escola (espaço formal) e a educação social acontece nas demais instituições sociais (não formal) que não seja na escola. Na visão de alguns estudiosos da área da Pedagogia Social, isso resulta num equívoco. Pois, bem sabemos que uma área complementa a outra e ambas podem acontecer de maneira harmoniosa.

E por fim, existe um questionamento latente sobre a Pedagogia Social, que diz respeito a prioridade de conteúdos, ou seja, ao não "aligeiramento" do processo de aprendizagem, que defende a ideia de oferecer os conteúdos no período devido, para que não haja desfalque no oferecimento de conteúdos científicos. Pois, adiantando o período próprio para o ensino científico, e diminuindo o percurso que ele deve ocorrer, faz com que os conteúdos prioritários determinados pelos parâmetros curriculares nacionais sejam reduzidos, ou até mesmo nem vistos. Com isso, dar abertura para a execução de projetos como ações compensatórias oferecidas pelo governo, com o intuito de preparar as pessoas para servirem apenas como mão-de-obra, e que isso resulta num distanciamento entre a Pedagogia Social e Pedagogia Escolar.

Concluímos, portanto, que a Pedagogia Social e Pedagogia Escolar possuem semelhanças em alguns pontos, e contradições em outros, porém, ambas possuem o mesmo objetivo: a formação política com o desenvolvimento pleno visando a transformação social do indivíduo, uma vez que no percurso que ambas participam atuando diretamente nas ações educativas, sejam elas em espaços denominados formal e não formal, permite a mudança da própria realidade de vida, possibilitando a construção de projetos de vida pessoal e social.

\section{REFERÊNCIAS}

[1] GIL, A. C. Métodos e técnicas de pesquisa social. 5 ed. São Paulo: Atlas, 1999.

[2] BOBBIO, N. A era dos direitos. 19.ed. Rio de Janeiro: Elsevier, 1992.

[3] BOBBIO, N. et al. Dicionário de política. Brasília, Editora Universidade de Brasília. 2010.

[4] BRASIL. Constituição (1998). Constituição da República Federativa do Brasil, 1988. Brasília: Senado Federal. Disponível em: http://www.senado.gov.br/legislacao/const/con1988. Acesso em: 24 nov. 2016.

[5] .Lei Federal n 8069 de 13 de julho de 1990. Dispõe sobre o Estatuto da Criança e do Adolescente. Disponível em: http://www.jusbrasil.com.br/legislacao/1028079/estatuto-da-crianca-e-do-adolescente-lei-8069-90. Acesso em: 30 de out. 2016.

[6] CALimAN, G. Fundamentos teóricos e metodológicos da Pedagogia social na Europa (Itália). In: I Congresso Internacional de Pedagogia Social, 1., 2006, Anais eletrônicos. Faculdade de Educação, Universidade de São Paulo, Disponível

http://www.proceedings.scielo.br/scielo.php?pid=MSC0000000092006000100015\&script=sci_arttext. Acesso em: 10 dez. 2017.

[7] CALIMAN, G. Pedagogia Social: seu potencial crítico e transformador. Revista de Ciências da Educação UNISAL - Americana/SP - Ano XII - № 23 - 2º Semestre, 2010, p. 341-368.

[8] FREIRE, P. Pedagogia do oprimido. Rio de Janeiro: Paz e Terra, 1987. 
[9] GADOTTI, Moacir. Educação popular, educação social, educação comunitária. Conceitos e práticas diversas, cimentadas por uma causa comum, 2013. Disponível em: http://www.proceedings.scielo.br/pdf/cips/n4v2/13.pdf. Acesso em: 24 nov. 2016.

[10] GOHN, Maria da Glória. Educação não-formal, participação da sociedade civil e estruturas colegiadas nas escolas. Ensaio: Aval. Pol. Públ. Educ., Rio de Janeiro, v.14, n.50, p. 27-38, jan./mar. 2006. Disponível em: http://escoladegestores.mec.gov.br/site/8- biblioteca/pdf/30405.pdf. Acesso em: 04 de jun. 2016.

[11] LUDKE, M.; ANDRÉ, M. E. D. A. Pesquisa em educação: abordagens qualitativas. São Paulo: EPU, 1986.

[12] OliVEIRA, M. W.; SILVA, P. B. G.; GONÇALVES JUNIOR, L.; MONTRONE, A. V. G.; JOLY, I. Z. L. Processos educativos em práticas sociais: reflexões teóricas e metodológicas sobre pesquisa educacional em espaços sociais. Anais da 32a Reunião da ANPED, 2009. Disponível em: http://32reuniao.anped.org.br/arquivos/trabalhos/GT065383--Int.pdf . Acesso em: 01 de abr. 2017.

[13] ONU (Organização das Nações Unidas). Declaração Universal dos Direitos Humanos. Adotada em 10 de dezembro de 1948. Disponível em: http://www.onu.org.br/img/2014/09/DUDH.pdf. Acesso em: 03 de mar 2017. 


\section{Capítulo 4}

Justiça social e globalização - Uma crítica das Cidades Inteligentes à luz da paridade participativa de Nancy Fraser

\section{Rodolfo Aparecido Leite}

Vitor Augusto de Carvalho Lins

Resumo: 0 objetivo deste artigo é apresentar uma análise crítica do modelo de Cidades Inteligentes à luz da concepção bidimensional de justiça de Nancy Fraser. Procura-se perfazer uma reflexão sobre dois projetos envolvendo o modelo de Cidades Inteligentes executados em solo brasileiro, sugerindo que, além da não ocorrência de justiça social, os agentes que experimentaram maiores ganhos político-econômicos são os governos e as grandes corporações tecnológicas. Utilizando-se de bibliografias relacionadas com o tema em questão, bem como artigos científicos, reportagens jornalísticas e a teoria da paridade participativa, a análise aponta para a discussão de que uma maior conexão entre as pessoas, possibilitada pelas chamadas Cidades Inteligentes, seja acompanhada de uma redução da desigualdade entre grupos sociais, atingindo-se, desta maneira, a justiça social objetivada pela socióloga norte-americana.

Palavras-chave: Cidades Inteligentes, globalização, justiça social, paridade participativa. 


\section{INTRODUÇÃO}

Vivemos em uma época em que diferentes culturas, bem como classes sociais, encontram-se segregadas umas das outras. Esta segregação acontece quando determinado número de pessoas, dentro de um espaço urbano, que compartilham gostos e preferências sociais e ideológicas, reúnem-se em várias espécies de tribos, provocando fenômenos como a falta de garantia de reconhecimento e participação de todas estas arregimentações sociais, bem como a falta de enquadramento na sociedade e a reificação das identidades coletivas, que podem ser sentidos por alguns destes grupos (FRASER, 2019). Dados de pesquisa elaborada pela Fundação Getúlio Vargas (NERI, 2019) demonstram a tão evidente desigualdade social brasileira, além das soluções tomadas pelos governos para atacar este problema, como a aplicação, por exemplo, de programas sociais de distribuição de renda. Conforme assinalado neste estudo:

Uma lição da crise atual é olharmos primeiro para os mais pobres, buscando protegê-los e assim preservando o movimento da economia como um todo. No bojo da crise de 1999, gestamos e depois parimos o Bolsa Escola federal; em meio as agruras da crise de 2003, nasceu o Bolsa Família. Na atual crise desaprendemos lições básicas. (NERI, 2019)

Contudo, nos tempos hodiernos, surge um modelo de administração pública urbana que une gestão e tecnologia, denominado Smart Cities, ou Cidades Inteligentes. Tal modelo tem como objetivo o aumento de eficiência administrativa em vários âmbitos das cidades por meio do uso de aparatos tecnológicos, promovendo o bem-estar dos moradores e formando uma congruência tecnológica em áreas como sustentabilidade, mobilidade, políticas econômicas, além da equalização social de todos os cidadãos residentes. Com isso, as Cidades Inteligentes buscam a integração de todos os grupos sociais aos aparelhos urbanos, sendo, portanto, um meio único de se atingir, de uma só vez, o reconhecimento e a participação de todos os grupos sociais diversos vistos nas grandes metrópoles.

Diante do exposto, o objetivo deste artigo é apresentar uma análise crítica do modelo de Cidades Inteligentes à luz da concepção bidimensional de justiça defendida pela socióloga americana Nancy Fraser. Assim, com base nesta concepção de justiça e em informações levantadas em meios midiáticos, observa-se que o mote principal desse modelo, ou seja, a integração e equalização social, não se realiza conforme o proclamado, porquanto os grandes projetos implementados no Brasil apresentam os governos e o grande capital como principais beneficiados, sem que a paridade participativa defendida por Fraser esteja sendo observada nas cidades que adotam tal modelo.

\section{METODOLOGIA}

Esse artigo tem por base uma análise bibliográfica, reunindo publicações sobre o tema Smart Cities, como artigos científicos e reportagens de jornais. Utilizamos também a teoria de Nancy Fraser, em particular sua concepção bidimensional de justiça.

\section{RESULTADOS}

Smart Cities, ou Cidades Inteligentes, é um termo utilizado para cidades sustentáveis, que têm como objetivo principal a resolução de problemas e outros tipos de demandas com ajuda de tecnologias, promovendo o "bem-estar dos cidadãos, aumentar o nível de sustentabilidade e alavancar o crescimento econômico" (VELOSO, 2019). Ainda segundo o pesquisador da Fundação Getúlio Vargas, André Lemos, as cidades inteligentes têm: "o intuito de tornar as atividades urbanas mais eficientes e sustentáveis nas esferas econômica, social, ecológica e política" (LEMOS, 2019). Dentre os assuntos urbanos mais atacados pelo modelo tecnológico vanguardista, destacam-se a mobilidade urbana, a coleta de lixo e a distribuição de energia elétrica. Considerando que a tecnologia avança a passos largos, o pesquisador também destaca que: "com uma ampliação considerável do acesso à internet das várias camadas da sociedade brasileira e mundial, passando de 361 milhões para 2,4 bilhões entre 2000 e 2013" (LEMOS, 2013), facilita-se o acesso a várias informações instantaneamente, em que se consomem e distribuem notícias e conhecimentos em geral. Com isso, ainda segundo este autor, o cidadão consegue ter uma percepção melhor do meio em que vive, propondo soluções inovadoras e criativas para sua cidade, gerando ações políticas que visam a melhora de certos indicadores nocivos à sociedade urbana, tais como poluição, níveis de ruído, problemas no trânsito e na segurança pública (LEMOS, 2013). 0 termo "cidades inteligentes", usado para cunhar um modelo de administração das cidades, foi desenvolvido pela iniciativa privada no começo do século XX, 
época em que se buscava a construção de cidades inteiramente novas, com infraestruturas avançadas e com vasto investimento de empresas de tecnologia (FIGUEIREDO, 2016).

Segundo Andrade \& Galvão (2019), a realidade das Smart Cities em terras tupiniquins já demonstra que o modelo ensaia uma expansão emergente, ainda que no momento se demonstra tímida. Algumas cidades aparecem no ranking das mais inteligentes do país, como os casos do Rio de Janeiro, São Paulo, Belo Horizonte, Brasília, Curitiba, São Caetano do Sul, Vitoria, Florianópolis, Porto Alegre e Recife. Algumas destas ainda fazem parte da Rede Brasileira de Cidades Inteligentes e Humanas, com destaque para a cidade do Rio de Janeiro que, em dezembro de 2013, levou o prêmio Smart City World Award, em reconhecimento à modernização dos modelos de gestão e desenvolvimento urbano em diversas áreas, como saúde, segurança pública e mobilidade.

São José dos Campos também prossegue neste mesmo rumo, utilizando novas tecnologias para melhorar e facilitar a vida das pessoas, com acesso público à Internet em parques e praças municipais (OTTOBONI, 2018), controle semafórico inteligente (O VALE, 2017), aplicativos para agendamento médico e consulta de disponibilidade de medicamentos de alto custo na rede pública (G1 VALE DO PARAÍBA E REGIÃO, 2017) além da instalação de modernas lâmpadas de LED nas vias e prédios públicos (OTTOBONI, 2018). 0 município, inclusive, lançou um edital de licitação, o pregão presencial no. . 164/SGAF/2018 (PREFEITURA DE SÃO JOSÉ DOS CAMPOS, 2018), envolvendo a temática de Cidades Inteligentes, solicitando, dentre outros serviços, conectividade, telecomunicações e imagens entre unidades da prefeitura. Em fevereiro de 2019, o pregão foi suspenso graças ao deferimento de um Mandado de Segurança no procedimento №. 2034569-32.2019.8.26.0000 (SÃO PAULO, 2019), a uma das organizações que concorrem ao certame, que questiona eventuais nulidades no procedimento.

Com o objetivo de estudar este tipo de fenômeno, Picchai \& Carneiro (2019), elaboraram estudo sobre as dificuldades enfrentadas pelas empresas ao implementar seus projetos nos municípios brasileiros, apontando os maiores empecilhos encontrados por 21 empresas em um procedimento licitatório. Segundo estes autores, o resultado é alarmante: os maiores problemas durante os certames com o poder público são a dificuldade de recebimento pelos serviços prestados e a carência de informações no edital, numa obstrução por parte do Estado em determinar quais empresas serão agraciadas com o direito de emplacarem seus projetos envolvendo Cidades Inteligentes.

Para a Prefeitura de São José dos Campos, essas tecnologias são inerentes ao processo administrativo e servem para aproximar o munícipe do gestor público e, além disso, a administração da cidade precisa acompanhar esses novos processos que surgiram para melhorar as relações sociais (OTTOBONI, 2018). Além disso,

Cidades Inteligentes não diz somente sobre tecnologia, mas como as decisões são tomadas nas grandes áreas urbanas, uso consciente de recursos naturais, planejamento urbano, onde todos, sem exceção, podem e devem participar para uma gestão democrática das cidades. (OTTOBONI, 2018)

Com a crise oriunda de 2007/2008, empresas de tecnologia encontraram nas gestões públicas clientes em potencial para vender seus produtos e serviços, por meio de investimentos em infraestrutura para aquisição e processamento de grande volume de dados, com o objetivo de provocar as cidades a perceber e a reagir, mais dinamicamente, às situações mais complexas (FIGUEIREDO, 2016). Em decorrência da necessidade de uma resposta à população contra desastres naturais, como uma tempestade de 2010 que provocou inúmeras vítimas, e a vinda de eventos esportivos de alta magnitude e alcance mundial, como a Copa do Mundo de 2014 e as Olimpíadas de Verão de 2016, o Rio de Janeiro recebeu um grande aporte paro implemento de projetos tecnológicos. Contudo, viu-se que era necessária uma manobra do governo em parceria com a iniciativa privada para que articulações fossem feitas o mais breve possível em resposta a problemas e situações de emergência na cidade (TAMBELLI, 2018).

Deste modo, foi firmada uma parceria entre prefeitura e a IBM com um custo estimado em 70 milhões de reais para a implantação do COI (Centro de Operações Integradas), onde por meio de concessionarias e mais de 30 órgãos públicos tinham a função de monitorar e otimizar o funcionamento da cidade com tomadas de decisões rápidas (TAMBELLI, 2018). Dessa forma, é possível otimizar o uso de recursos e de infraestruturas da cidade com o emprego dessa tecnologia, buscando solucionar ou, ao menos, aliviar problemas urbanos não só relativos a deslizamentos e enchentes, como também à mobilidade, à poluição, ao uso de energia, à violência, entre muitos outros. 
Esse modelo, que promete melhorar a eficácia da gestão pública utilizando aparatos tecnológicos, é debatido extensivamente entre as mais variadas esferas governamentais do mundo e as empresas detentoras da expertise deste tipo de trabalho.

\section{DISCUSSÃO}

Para os fins de nossa discussão, observamos que a socióloga americana Nancy Fraser desenvolveu uma teoria que aponta alguns obstáculos que as sociedades pós-modernas enfrentam neste cenário globalizado que marca o momento atual da humanidade. Segundo a autora: "o risco da substituição das lutas pela redistribuição pelas lutas do reconhecimento" (FRASER, 2019, p. 19), "o risco da atual centralidade da política cultural, que está a reificar as identidades sociais e a fomentar um comunitarismo repressivo [...] subversão das capacidades do Estado para reparar ambos os tipos de injustiça" (FRASER, 2019, p. 10) impedem o fomento da justiça social no cenário de globalização. Como solução, a autora traz a teoria da paridade participativa, ou seja, uma política única que reúne em seu corpo principal medidas que garantem o reconhecimento de todos os grupos sociais, bem como a redistribuição de recursos que conferem por direito a cada um. "Desta perspectiva bifocal, torna-se desnecessário optar entre uma política de reconhecimento e uma política de redistribuição, impondo-se, pelo contrário, uma política que abarque os dois aspectos." (FRASER, 2019, p. 12). Com base nesta teoria buscamos analisar, nas próximas linhas, se o atual momento das Cidades Inteligentes pode ser enquadrado como modelo de gestão pública que promove a paridade participativa defendida por Fraser, a fim de se alcançar a justiça social tão exigida pelo cenário globalizado do mundo atual.

Ao analisar as informações sobre as implementações que o modelo de Cidades Inteligentes assistiu ao longo deste princípio de século, infere-se que os resultados, a despeito daquilo que o modelo pretende solucionar e melhorar, não refletem aquilo que a teoria de Fraser propõe como medida de alcance à justiça social. Enquanto as camadas mais pobres e carentes da população sofrem com a crescente alienação urbana trazida por fenômenos como a gentrificação, os projetos que têm como mote as Cidades Inteligentes, que a princípio visam a integração total das diversas camadas sociais presentes nos espaços urbanos em um sistema único tecnológico, na prática, não alcançam tal objetivo. Pelo contrário, os beneficiados por este modelo de gestão municipal são as grandes empresas e os governos, numa evidência de que as chamadas Cidades Inteligentes não contribuem para o fomento da justiça social.

0 urbanista holandês Ton Dassen, em entrevista concedida ao jornal Folha de São Paulo, especifica que o grande objetivo por trás das Cidades Inteligentes é o ganho em comum de governos e dos grandes conglomerados tecnológicos. Conforme afirma esse especialista:

Há um enorme debate no mundo sobre cidades inteligentes. Mas há intenções claras por trás disso. É uma coalizão de interesses de governos e grandes empresas de tecnologia. 0 discurso sobre cidade inteligente tem demonstrado pouca sensibilidade sobre o contexto em que elas terão que ser construídas. Não há relação com uma proposta de reforma social. É inovação tecnológica, não social ou institucional. (FRANCO, 2019)

0 que o urbanista holandês afirma é demasiado alarmante. 0 que era para ser um projeto que tem como objetivo os ganhos em eficácia na gestão administrativa, aumento da sustentabilidade e crescimento urbano-econômico, de fato não passa de uma disputa por capital entre o governo e os grandes grupos empresariais do ramo da tecnologia. Ou seja, enquanto a população é esquecida pelo poder público, sofrendo com a falta de reconhecimento e redistribuição de recursos, àqueles agentes interessam somente as altas somas monetárias enquanto implementam projetos mascarados com promessas aos moradores que não se concretizam na prática. De acordo com a denúncia feita por esse urbanista, não é possível afirmar haver justiça social segundo a paridade participativa conforme descrita por Fraser. Dessa forma, escreve Tambelli (2018):

Não bastaria, assim, implementar mecanismos sofisticados de integração tecnológica sem pensar na necessidade de aumentar o interesse dos usuários pela utilização desse sistema, ensinar as habilidades básicas para o uso e, às vezes também, munir o cidadão do dispositivo eletrônico correto. Em relação a esta última necessidade, corre-se o risco, ainda, de um aprofundamento das desigualdades, uma vez que poderiam acentuar exclusões de pessoas despossuídas financeiramente ou mesmo pessoas que vivem em áreas remotas ou periféricas da cidade. 
O jornalista Steven Poole, do periódico inglês The Guardian, escreveu artigo em 2014 que vai ao encontro das teorias descritas pelo urbanista holandês, denominado "A verdade sobre as smart cities: Ao seu final, elas destruirão a democracia". Nesta matéria, o articulista reflete se as cidades devem funcionar como panópticos otimizados ou devem ser verdadeiros caldeirões de culturas e ideias (POOLE, 2019, tradução do autor). 0 inglês defende a tese de que, além dos benefícios político-financeiros dos governos e das chamadas Big Techs, as Cidades Inteligentes reduzem os moradores a meros fornecedores de informações pessoais alheios à sua vontade, sem obter nenhum ganho social aparente dentro do espaço urbano. Citando o urbanista Dan Hill, esse jornalista pontua que "Esta coisa inteligente é nada mais do que TI uma cidade inteligente pode ser uma cidade com poucas emissões de carbono, ou uma cidade de fácil mobilidade ou uma cidade com empregos e moradia". 0 jornalista afirma, ainda, que

[...] graças ao aumento da conectividade onipresente à Internet e à miniaturização da eletrônica em dispositivos agora comuns como etiquetas RFID, o conceito parece ter se cristalizado em uma imagem da cidade como um robô vasto e eficiente - uma visão que se originou, de acordo com Adam Greenfield em LSE Cities, com gigantes companhias de tecnologia como IBM, Cisco e Software AG, todas as quais esperavam lucrar com grandes contratos municipais. (POOLE, 2019, tradução do autor)

Um dos exemplos citados por Poole (2019) é a Prefeitura do Rio de Janeiro com seu centro de operações construído pela IBM, cujas características remetem a um mundo sob constante vigilância estatal, descrito em detalhes pelo romance ficcional "1984", de George Orwell. Infere-se do artigo que um ambiente urbano com alta tecnologia empregada em nada melhora a vida social dos moradores, pois estes ainda sofrem das consequências trazidas pela desigualdade social tão comum em grandes metrópoles brasileiras e mundiais, ou seja, as cidades continuam sendo desiguais, porém conectadas. Sendo assim, os problemas comuns a todas as grandes cidades acabam migrando para os ambientes virtuais - a luta por justiça social é um deles - sem perspectiva de melhora.

O caso de São José dos Campos sugere que existe uma disputa entre o governo municipal e conglomerados tecnológicos no tocante à implementação de projetos envolvendo Cidades Inteligentes, tendo como palco principal o regramento brasileiro que regula os procedimentos de licitação. Ao realizar o certame na modalidade de Pregão, a Prefeitura do município foi abarrotada de questionamentos judiciais por parte das empresas participantes, gerando o Mandado de Segurança no procedimento no 2034569 32.2019.8.26.0000 (SÃO PAULO, 2019) que gerou a suspensão do processo. Ora, o que se infere desta questão é que a batalha judicial entre o Estado e as companhias tecnológicas em nada ajuda na melhora da percepção de justiça social a ser conseguida pelos cidadãos. Ora, o caput do Art. 3o da Lei 8.666/93 (BRASIL, 1993) reproduz um dos princípios licitatórios em comum com a prerrogativa das Cidades Inteligentes: desenvolvimento sustentável. É de se concluir que, entre os agentes supracitados, a paridade participativa poderia ser atingida adequadamente, garantindo a percepção da concepção bidimensional de justiça aplicada em solo urbano, como assinala a socióloga americana. No entanto, este objetivo é completamente mitigado graças aos maiores beneficiários da contenda descrita: o governo municipal e as empresas de tecnologia. Deste modo, não importa qual destes dois agentes se agraciará vencedor - o maior beneficiário deveria ser a própria população, contudo, esta se encontra totalmente alienada desta guerra burocrático-financeira, à margem de eventuais negociatas que envolvem os projetos do modelo de Cidades Inteligentes, vivendo suas vidas em função daqueles que procuram lucrar com os serviços impostos pela vanguarda tecnológica, sem ao menos se dar conta do que são e quem são os fenômenos e agentes beneficiários deste modelo.

Como visto nos exemplos acima debatidos, reiteramos que nas chamadas Cidades Inteligentes não promovem o caráter bidimensional de justiça necessária para cenário hodierno, pois "o único tipo de concepção capaz de abranger toda a magnitude da injustiça no contexto da globalização". (FRASER, 2019, p. 11) não é observado por conta dos ganhos restritos somente aos mais poderosos.

\section{CONCLUSÃO}

A teoria de Nancy Fraser procura contribuir para a compreensão dos óbices existentes para que as diversas camadas sociais possam alcançar a tão desejada justiça social num cenário de extrema aproximação em relações político-econômicas entre os países, observadas nos cinco continentes espalhados pelo globo, fenômeno este conhecido nas mais diversas teorias acadêmicas como globalização. Estes obstáculos são determinados pela falta de reconhecimento de todos os grupos sociais difusos presentes nas cidades, bem como a má redistribuição de recursos que lhes são devidos. 
De acordo com esse lastro deixado pela autora, surge como proposição sugestiva de maneira a resolver estes impasses a teoria da paridade participativa, na qual é suscitada uma política que relata em seu corpo principal o dever-ser do reconhecimento de todas as agremiações sociais e as maneiras de redistribuição de recursos, reunidos em um único estatuto. Uma das alternativas que procura garantir a paridade participativa de todos os grupos sociais no desenvolvimento de uma cidade e a percepção da justiça social é o modelo de gestão municipal conhecido como "Cidades Inteligentes". Deste modo, o objetivo deste artigo foi apresentar uma análise crítica deste modelo à luz desta teoria elaborada pela socióloga americana Nancy Fraser. Concluímos que o modelo de Cidades Inteligentes, tão requisitado pelo cenário de estratificação social contemporâneo, não corrobora que a sua inserção de fato melhore a vida de todos em sociedade. Enquanto a política de paridade participativa surge como uma teoria clara de obtenção de melhorias sociais através da proposta de equalizar todas as camadas sociais em um único ponto em comum nos âmbitos político e econômico, as denominadas Cidades Inteligentes, aparentemente, agem para obstar tal objetivo, pois somente dois componentes sociais - os governos e as grandes corporações saem vencedores com a implementação de tal modelo. A população, conquanto conectada e com facilidades tecnológicas que aceleram a resolução de seus problemas, permanece estratificada, sem ao menos notarem tal situação. Todas as camadas populacionais, com as Cidades Inteligentes, saem em desvantagem; suas discussões migram do plano real para o plano virtual. Assim, uma maior conexão entre as pessoas, possibilitada pelas chamadas Cidades Inteligentes, deve vir acompanhada de uma redução da desigualdade entre grupos sociais.

\section{REFERÊNCIAS}

[1] ANDRADE, J. N.; GALVÃO, D. C. O conceito de smart cities aliado à mobilidade urbana. Revista HUM@NAE, v.10, n.1, 2016. Disponível em:< http://humanae.esuda.com.br/index.php/humanae/article/view/478/150>. Acesso em: 26 ago. 2019.

[2] FIGUEIREDO, G. M. P. Cidades Inteligentes no contexto brasileiro: A Importância de uma reflexão crítica, 2016. Disponível em:<https://www.anparq.org.br/dvd-enanparq-4/SESSAO\%2044/S44-04-FIGUEIREDO,\%20G.pdf>. Acesso em: 10 de ago. 2019.

[3] FRANCO, L. 'Cidade inteligente' não é garantia de melhorias sociais, diz urbanista. Folha de São Paulo. São Paulo, 24 de maio de 2015. Disponível em: <https://www1.folha.uol.com.br/cotidiano/2015/05/1633023-cidadeinteligente-nao-e-garantia-de-melhorias-sociais-diz-urbanista.shtml>. Acesso em: 10 ago. 2019.

[4] FRASER, N. A justiça social na globalização: Redistribuição, reconhecimento e participação. Revista Crítica de Ciências Sociais, Coimbra, 2002. Disponível em:< https://www.ces.uc.pt/publicacoes/rccs/artigos/63/RCCS63Nancy\%20Fraser-007-020.pdf>. Acesso em: 26 ago. 2019.

[5] LEMOS, A. Cidades inteligentes. GVExecutivo, Disponível em:<http://bibliotecadigital.fgv.br/ojs/index.php/gvexecutivo/article/view/20720/19454. Acesso em: 26 ago. 2019.

[6] NERI, M. Desigualdade e pobreza em alta. Disponível em:<https://www.cps.fgv.br/cps/bd/clippings/tc349.pdf>. Acesso em: 18 ago. 2019.

[7] оттовоNI, J. Cidades Inteligentes influenciam São José. DCI, 2018. Disponível em: <https://www.dci.com.br/dci-sp/cidades-inteligentes-influenciam-s-o-jose-1.701224>. Acesso em: 09 maio 2019.

[8] PICCHAI, D.; CARNEIRO, M. Dificuldades e estratégias de micro e pequenas empresas na participação de

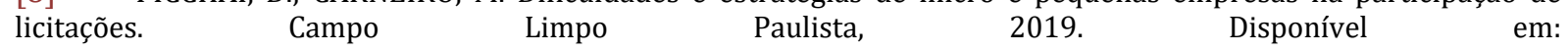
<http://www.revistasg.uff.br/index.php/sg/article/view/1491/html>. Acesso em: 13 maio 2019.

[9] PREFEITURA DE SÃO JOSÉ DOS CAMPOS. Aplicativos para celular. [S.l.], [201-]. Disponível em:<https://www.sjc.sp.gov.br/servicos/governanca/aplicativos-para-celular/>. Acesso em: 14 maio 2019.

[10] PREFEITURA de São José testa sistema de tecnologia para melhorar o trânsito. O VALE, São José dos Campos, 25 de julho de 2017. Disponível em: <https://www.ovale.com.br/_conteudo/2017/07/nossa_regiao/12403prefeitura-de-sao-jose-testa-sistema-de-tecnologia-para-melhorar-o-transito.html>. Acesso em: 14 maio 2019.

[11] SÃo José tem novo sistema para consultar disponibilidade dos remédios de alto custo. G1 Vale do Paraíba e região, 2017. Disponível em:<https://g1.globo.com/sp/vale-do-paraiba-regiao/noticia/sao-jose-tem-novo-sistemapara-consultar-disponibilidade-dos-remedios-de-alto-custo.ghtml>. Acesso em: 9 maio 2019.

[12] SOROSINI, M. Reage, Rio!: investimento em mobilidade urbana é uma das soluções para uma cidade sustentável. O GLOBO, 2018. Disponível em:<https://oglobo.globo.com/rio/reage-rio-investimento-em-mobilidadeurbana-uma-das-solucoes-para-uma-cidade-sustentavel-22801945>. Acesso em: 14 maio 2019. 
[13] TAMBELLI, C. N. Smart Cities: uma breve investigação crítica sobre os limites de uma narrativa contemporânea sobre cidades e tecnologia, 2018. Disponível em:<https://itsrio.org/wpcontent/uploads/2018/03/clarice_tambelli_smartcity.pdf>. Acesso em: 10 ago. 2019.

[14] POOLE, S. The truth about smart cities: 'In the end, they will destroy democracy'. The Guardian, 2014. Disponível em:<https://www.theguardian.com/cities/2014/dec/17/truth-smart-city-destroy-democracy-urbanthinkers-buzzphrase?utm_medium=website\&utm_source=archdaily.com.br>. Acesso em: 10 ago. 2019.

[15] VELOSO, R. Descubra quais são os desafios das Cidades Inteligentes no Brasil. HOUER, 2019. Disponível em:<https://blog.houer.com.br/desafios-das-cidades-inteligentes-no-brasil/>. Acesso em: 10 ago. 2019. 


\section{Capítulo 5}

\section{Assentamento São Bento em Heitoraí-Go: Uma leitura do espaço cotidiano e da (re)produção das relações sociais de produção}

\section{Jean Carlos Ribeiro de Lima \\ Mary Anne Vieira Silva}

Resumo: 0 presente texto visa discutir sobre o Assentamento São Bento em Heitoraí Go numa perspectiva em que se possa demonstrar a (re)produção das relações sociais de produção no campo das análises do espaço cotidiano. Para isto, nos valemos dos pressupostos teóricos e metodológicos do sociólogo e filósofo francês, Henri Lefebvre, que lida com conceitos como, espaço, cotidiano, urbano, rural, entre outros. De modo geral, o espaço cotidiano do/no Assentamento São Bento se revela em suas peculiaridades sociais, se bastando em uma teia de relações sociais que se reproduzem nos interstícios do binômio capital-estado. Para as pretensões aqui apontadas, adotamos como recurso metodológico uma discussão bibliográfica untada com elementos da oralidade e análise documental.

Palavras-chave : Assentamentos rurais, Cotidiano, Heitoraí, 


\section{INTRODUÇÃO}

A pesquisa que ora se apresenta busca responder ao seguinte problema: Quais são as possibilidades de ruptura do binômio capital-estado no cotidiano do Assentamento São Bento, em Heitoraí, Goiás? O espaço produzido pelas forças do binômio capital-estado torna-se revelador das lógicas da reprodução das relações sociais de produção dadas no cotidiano. Nessa perspectiva as formas e os conteúdos do social, do político e das representações do trabalho são resultados conflitantes e contraditórios, materializadas no plano vivido. Em outra perspectiva, o cotidiano como plano do vivido é espaço das possibilidades, do surgimento dos novos sentidos do "uso".

Assim, os processos históricos e sociais resultaram de uma densa combinação de ações advindas das forças promovidas pelo binômio capital-estado. Dessa combinação o acesso à terra por camponeses se colocou como desvio de ruptura desse modelo dialeticamente, ainda, como sendo por meio de formas institucionalizadas de políticas públicas. Quais mudanças decorrem dessa relação que se apresenta de forma dialética para o direito à terra em Heitoraí-GO? Estas são questões pontuais no entendimento da configuração da (re)produção das relações de produção que pululam no cotidiano dos assentados e de suas narrativas de vida.

Assim, o presente trabalho empenha-se em desnudar as possibilidades de enfrentamento do cotidiano "capturado" pelo binômio capital-estado na dinâmica socioespacial do Assentamento São Bento. Nesse sentido, utilizamos como método as premissas de Henri Lefebvre (2006) ao tocante das análises do espaço e da vida cotidiana como fruto das relações de produção em um campo de abordagem que escapa ao determinismo econômico, que por sua vez, procura evidenciar elementos outros de estudos das relações sociais que se operam no contexto da sociedade capitalista.

\section{O CONTEXTO HISTÓRICO DE FORMAÇÃO DO ASSENTAMENTO SÃO BENTO}

No espaço das transformações políticas, sociais e econômicas, Heitoraí surge a partir de uma perspectiva resultante dos projetos de ocupação dos espaços vazios mediante concessão de terras devolutas. De acordo com Nascimento dos Santos et al (2006), uma família de descendência portuguesa, os Guedes, mediante requerimento, pedem concessão ao governo de algumas terras devolutas, onde hoje se encontra o município de Heitoraí-GO33, para exploração agrícola. Concedida as terras, pouco tempo depois os Guedes entram em falência e vendem boa parte das terras aos Crisóstomos, outra família tradicional.

Ressalta Castilho (2007) que as terras adquiridas primeiramente pelos Guedes e logo depois pelos Crisóstomos, foram sendo vendidas e repartidas, configurando o que hoje é Heitoraí. Pequenas colônias agrícolas foram se instalando nos arredores das fazendas da região, onde trabalhadores rurais migrados especialmente de Minas Gerais, se estabeleceram. De acordo com Lima (1999) a devoção e a fé dos fazendeiros da região se apresentava de modo intenso, o que mais tarde resultou numa doação de terras para a construção de uma capelinha. Foi em torno dessa capelinha que as primeiras casas foram sendo construídas, resultando mais tarde no município de Heitoraí.

Desse modo, entender a formação do espaço territorial de Heitoraí se faz necessário para compreender em que sentido se configura as relações de trabalho, de comercialização, de exploração das terras, dos conflitos, etc. No conjunto das abordagens suscitadas, o Assentamento São Bento resulta de uma ação, a partir de 1996-1997, de questionamento da função social de algumas propriedades rurais do município, culminando na desapropriação e efetivação do assentamento ${ }^{4}$.

A compreensão da formação do Assentamento São Bento em Heitoraí-GO requer uma retrospectiva histórica que considere elementos que se inserem no conjunto das análises que versam sobre a questão agrária em Heitoraí e que, como indicado, se constitui de conteúdos tradicionais e conservadores da estruturação do espaço agrário heitoraiense.

Nesse sentido, as formas de apropriação dos dados concernentes ao processo de formação do Assentamento São Bento se dividem em: a) trajetórias de vida diante uma experiência narrativa

${ }^{3} 0$ município de Heitoraí-GO faz parte da microrregião de Anápolis e se encontra na distância de 150 km de Goiânia.

${ }^{4}$ Vale ressaltar que Heitoraí conta com cinco assentamentos rurais (São Bento, Brumado, Lagoa Grande, Bom Jesus e Margarida Alves), todos criados a partir de 1996-1997. 
decorrente da oralidade dos assentados, e b) do Projeto de Criação do assentamento que se encontra nos arquivos do Instituto de Colonização e Reforma Agrária (INCRA), em Goiânia. Através desses instrumentos metodológicos conseguimos absorver os conteúdos históricos-sociais de configuração do Assentamento São Bento.

Segundo o assentado AX-1, o processo de construção histórica do assentamento se deu a partir da veiculação da notícia por interlocutores ligados à Comissão Pastoral da Terra (CPT), que realizavam um trabalho de "vigilância" sobre terras ou áreas que apresentavam indícios de desapropriação. Para tanto,

[...] Aí fez os convites, reuniu o pessoal; passaram a fazer reunião, só reunião nós fizemos mais de mês, lá em Goiás (Cidade de Goiás) numa sala da Igreja Católica. Aí nós fazendo essa reunião, encaixando quem que iria, quem não iria...aí como eu estava na fazenda lá (Mossâmedes) e arrumei um probleminha de saúde, porque grande parte das vezes o patrão só quer o peão quando ele está bem; mais graças a deus eu não tive nada sério. Aí eu já estava pensando de vir embora mesmo, porque era muito serviço só para mim e a esposa...e a fazenda lá era muito grande. Aí um amigo meu me chama para vir, né, para ocupar a terra e participar da reforma agrária. Eu resolvi tentar.

A respeito do dia em que ocorreu a ocupação e o início do acampamento,

Eu já vim direto para Heitoraí. Nós chegamos de caminhão, o famoso "pau de arara". Capaz que nesse dia nós éramos umas setenta pessoas. Porque na verdade deve ter vindo uns cinco ou seis caminhões...porque nós éramos 337 famílias. Aí veio gente de Goiás (Cidade de Goiás), de Itapuranga, do Mato Grosso...tinha gente de vários lugares. Daí logo nós já aprontamos e montamos o acampamento em prol de fazer uma coisa boa, né. Aí começamos a furar foça, cisterna...esses tipos de coisas.

Percebe-se que houve uma massiva participação de pessoas no momento de ocupação da área (onde hoje é o assentamento) passível de desapropriação para fins de reforma agrária. Em outras palavras, existia, por parte daqueles envolvidos na ocupação da respectiva área, uma disposição em obter, mesmo que temporariamente, uma expectativa de acesso à terra. Tal motivação serviu para concretizar o acampamento e estabelecer, a partir da ocupação, as diretrizes para a busca e realização do assentamento.

De outro lado, a propriedade, denominada de São Bento do Taquaral, que passa a ser requerida pelos acampados, se encontrava em desacordo com a função social terra, uma vez que não estava em pleno vigor de sua produção agrícola. A partir da constatação deste fato, as ações dos acampados se intensificaram junto ao INCRA para que o órgão competente desse início ao processo legal para a vistoria do imóvel, desapropriação, divisão das parcelas e estabelecimento e efetivação do assentamento.

No Laudo de Vistoria técnico realizado pelo INCRA na propriedade requerida pelos acampados, podemos perceber que a as condições para a implantação e viabilidade do assentamento foram constatadas. Em primeiro lugar verifica-se o não cumprimento da função social da propriedade. Em segundo, a confirmação da viabilidade para a concretização do assentamento.

Considerando-se as informações obtidas, temos a dizer que o imóvel em pauta não cumpre a sua função social, quanto: a) aproveitamento racional; b) utilização adequada dos recursos naturais disponíveis e preservação do meio ambiente; c) observância das disposições que regulam as relações de trabalho; d) exploração que favorece o bem-estar do proprietário e dos trabalhadores (DIVISÃO DE ASSENTAMENTOS, SUPERINTENDÊNCIA REGIONAL DO INCRA LAUDO DE VISTORIA № 104/97, p. 11 - GOIÂNIA, SALA T-2, ARMÁRIO № 5). 
A respeito da viabilidade para implementação do assentamento, tem-se que

Tendo em vista oportunizar o acesso à terra, a uma população de agricultores em condições favoráveis para a aquisição de uma propriedade rural dentro dos moldes convencionais, vistoriou-se o imóvel rural constante do presente Laudo e, em função das informações relativas a: altitude, infraestrutura de serviços na região, relevo, clima, vegetação, solos, hidrografia, cacacidade de uso das terras, uso da terra, produção etc, conclui-se que a área é propícia ao assentamento de famílias de trabalhadores rurais contanto que haja a correção da acidez do solo, agilização de fertilizantes, uso de tecnologia adequada, preservação dos recursos naturais e medidas de combate à erosão entre outros. Seriam criados então, novas unidades agrícolas, dentro dos padrões racionais de exploração da terra, que proporcionaram a esses trabalhadores, uma propriedade rural que possibilitaria a sua evolução econômica e social, tendo em vista o processo produtivo. As terras do imóvel são propícias à produção de colheitas regulares a boa de culturas temporárias, como: arroz, milho mandioca, feijão, etc, banana, e uma pecuária altamente competitiva (DIVISÃO DE ASSENTAMENTOS, SUPERINTENDÊNCIA REGIONAL DO INCRA - LAUDO DE VISTORIA № 104/97, p. 11 - GOIÂNIA, SALA T-2, ARMÁRIO № 5).

A constatação de que o imóvel se apresenta viável para impor-se em assentamento é evidenciada pela fertilidade e produtividade do solo, as condições de hidrografia, relevo, clima, vegetação, etc., bem como para a constituição em unidades para a exploração agrícola. Em desacordo com a função social da terra, imposta no Estatuto da Terra (1964) e ratificada na Constituição de 1988, a área requerida então é viabilizada para a instalação do assentamento.

Em consonância com as conclusões dispostas no Laudo de Vistoria da área requerida para fins de reforma agrária, os acampados organizados se imputaram em estar diariamente acompanhando o andamento do processo no INCRA, em Goiânia. A proposta de acompanhamento do processo atinente à efetivação do assentamento no INCRA fez parte de uma metodologia adotada pelos assentados para acelerar o processo, que para alguns, estava lento e procrastinando. Desse modo, comenta o assentado AX-2 que

Foi muito lento...lento...lento. Tentou empurrar com a barriga muito tempo. Os papel tudo arrumado. Enquanto nós...aí já vem a história que eu estou contando pra você; se nós se unir e correr atrás, né...consegue. Aí foi indo, marcava as reunião mais não resolvia. Aí um dia o nosso presidente (do acampamento) marcou uma reunião com o superintendente lá...e aí o que que nós fez, nós foi quarenta e tantas pessoas...lotou um ônibus e amanheceu lá dentro do INCRA. Nós entrou pra sala dele e ficou quietinho lá dentro; quando ele (o superintendente) entrou ele deu de testa com o povão lá dentro. 0 que que ele fez...tanto que ele é sem vergonha, só riu. Ele (o superintendente) sabia né que tinha alguma coisa. E aí ele abriu a discussão...aí no final ele foi sincero...aí falou que na semana que vem eu vou arrumar lá porque eu já empurrei vocês demais com a barriga aí. Já na outra semana estava tudo arrumado. Tem jeito tem, mais tem que unir e correr atrás. Aí na outra semana já saiu para medir e tudo.

Ao acompanhar o processo no INCRA, os acampados se informavam sobre todos os acontecimentos referentes ao assentamento. Após a conclusão do Laudo de Vistoria editado pelo INCRA, o próximo passo era a confirmação, via decreto presidencial, da desapropriação do imóvel para fins de reforma agrária e criação do assentamento. No mesmo ano de conclusão do Laudo de Vistoria, ou seja, 1997, o decreto $\mathrm{n}^{\circ}$ 195 de 8 de outubro de 1997 asseverava a fim da instalação do assentamento e a desapropriação da área requerida. 
O PRESIDENTE DA REPÚBLICA, no uso de suas atribuições que lhe confere os arts. 04 , inciso IV, o 184 da Constituição, e nos termos dos arts. 18 e 20 da Lei no 4.504, de 30 de novembro de 1964, $2^{\text {a }}$ da Lei no 8.620, de 25 de fevereiro de 1993, e 2o da Lei Complementar no 76, de 6 de julho de 1993,

\section{DECRETA:}

Art. 1o Fica declarado de interesse social, para fins de reforma agrária, nos termos dos arts. 18; letras "a", "b", “c" e "d"; a 20, Inciso VI, da Lei no 4.504, de 30 de novembro de 1964, e $2^{\text {a }}$ da Lei no 8.629, de 25 de fevereiro de 1993, o imóvel rural denominado "Fazenda São Bento do Taquaral", com área de $1.134,9000$ há (um mil, cento e trinta e quatro hectares e noventa e oito ares), situado no Município de Heitoraí, objeto dos Registros nºs R-2-700, fls. 225 e R2-700, fls. 226, ambos do Livro 2-B, do Cartório de Registro de Imóveis, Títulos, Documentos, Protesto, Pessoa Jurídica e Tabelionato de Notas da Comarca de Itaberaí, Termo de Heitoraí, Estado de Goiás (DIVISÃO DE ASSENTAMENTOS, SUPERINTENDÊNCIA REGIONAL DO INCRA - DECRETO DE 8 DE OUTUBRO DE 1997, p. 2 - GOIÂNIA, SALA T-2, ARMÁRIO № 5).

Nos termos do decreto fica evidente a desapropriação do imóvel supracitado para fins de "interesse social". A nomenclatura designada de "interesse social" prevista na Constituição (1988) interpõe-se à de interesse privado no contexto do não cumprimento da função social, que no caso em particular, de não cumprimento com a produção agrícola e outros. Nesse sentido, o decreto autoriza o INCRA, em seu atr. $3^{\circ}$, a promover a desapropriação do imóvel rural, manter Reserva Legal e implantar o assentamento de acordo com suas metodologias, destinando uma área de preservação ambiental.

Após a desapropriação, os procedimentos seguintes se definiram a partir da imissão de posse pelo INCRA do imóvel objeto da ação, da criação da proposta de assentamento rural e, por fim, da seleção dos acampados e divisão das parcelas, que se concretizou via sorteio. Desde então o Assentamento São Bento começou a receber subsídios do INCRA para sua efetiva concretização. Isto foi possível graças a acesso ao crédito e financiamento de programas específicos, como por exemplo o Programa Nacional de Fortalecimento da Agricultura Familiar (PRONAF).

\section{DISCUSSÃO TEÓRICA E METODOLÓGICA}

A demarcação teórica dar-se-á por campos clássicos que evocam a composição do campesinato a partir das contribuições de José de Souza Martins (1990); o autor traça uma análise histórica, política, econômica e social, assentada sobre uma crítica - ancorada sobre o materialismo histórico dialético - acerca da formação do campesinato brasileiro a partir dos processos formadores do território nacional.

A despeito da trajetória histórico-política e social do camponês, nota-se, com efeito, que os assentamentos rurais se inserem numa teia de resistências face à lógica do capital. De acordo com Jadir Pessoa (1999) é a partir das décadas de 1960 e 1970, que especificamente surge um "novo campesinato", com características próprias de sociabilidades, identidades, representações, organização e resistência. É a partir de uma inevitável tenção entre rupturas e continuidades, que podem ser encontrados elementos significativos para se afirmar a existência de um "novo camponês", que se promove enquanto sujeito histórico, social, político, econômico e, mais além, como sujeito que resiste e luta.

Em consonância com o exposto, Caio Prado Junior (1963) dispõe de argumentos práticos-concretos sobre a composição do território nacional no âmbito da História Econômica e Social. Sua tese versa sobre o tripé latifúndio, monocultura e escravidão que definiu, grosso modo, a estrutura agrária da sociedade brasileira.

A partir desta análise de formação e construção do território, abordaremos seguidamente a proposta de estudo teórico que ancora esta pesquisa, a saber, a questão que envolve o conceito de "reprodução do espaço", que neste caso, centra-se nas contribuições teórico-metodológicas de Henri Lefebvre. 
Para o autor, o plano da vida se fragmenta por vivências traduzidas por diferenças; aqui, se descortina o processo de apreensão do que se trata por cotidiano. Lefebvre (2006), considera o espaço como resultado da ação humana enquanto projetos de representações que subsistem e, logo, se integram a outras formas de ver e conceber o mundo. Em síntese, as "representações" dos sujeitos sociais, está ancorada numa Teoria das Representações do espaço e da vida.

A assertiva de Lefebvre é corroborada por Valtuir Silva (2008, p. 41), em que este afirma ser o cotidiano categoria essencial para compreensão das resistências instituídas a partir do campo. Na perspectiva do autor, "esse cotidiano não pode ser entendido apenas como imposição, através de poderes constituídos, mas como capaz de instituir significados, de tentar moldar a vida e seus valores, num processo em que aparecem os vários exemplos de resistência".

Assim, deve-se procurar entender os meios de adaptação dos assentados do São Bento em relação ao espaço, ao território, ao trabalho e a cultura. Compreender também e acima de tudo, a relação de pertença desses sujeitos com a terra, ou seja, o espaço e o território que se faz pertencer. Nesta direção, Denis Castilho (2007) assinala que é necessário depreender as variadas formas de resistências advindas do campo não apenas pelo caráter político, mas também, levando em consideração uma ideia de "ambientação socioespacial", entendida como um processo de relação de pertença dos sujeitos com o território.

Isto posto, entende-se que o estudo da ruralidade brasileira seja de importância capital. Sérgio Leite (2004) enfatiza que o estudo e a compreensão dos assentamentos rurais passam, necessariamente, por uma interpretação do meio rural, seu contexto histórico e os sujeitos sociais pertencentes a este. Em mesma direção, Sônia Bergamasco (2003) assinala que os assentamentos, de modo geral, estão relacionados com a ideia de Estado, poder e Reforma Agrária. Segundo a autora, a perspectiva dos assentamentos rurais é histórica, envolve uma complexa relação de poder e políticas públicas.

Por outro lado, é preciso pensar os assentamentos a partir de seu interior. Analisar, segundo consta os pressupostos teóricos de Rosimeire Scopinho (2012), a organização dos sujeitos pertencentes a este espaço (dos assentamentos), as estratégias de produção e relações sociais, políticas, econômicas e culturais, é fundamental para promover qualquer debate sobre a política de assentamentos.

Em última instância, Gerd Sparovek (2005) assevera que qualquer debate ou discussão sobre assentamentos rurais passa por uma verificação atenta e cautelosa acerca da questão da Reforma Agrária. Pesquisar as trajetórias socioespaciais dos assentamentos é um profícuo debate sobre as políticas de reforma da estrutura agrária brasileira, bem como sobre os conflitos no campo e as forças políticas em jogo.

\section{METODOLOGIA}

Intenta-se, num primeiro momento, realizar uma pesquisa bibliográfica sobre o tema Assentamentos Rurais. Num segundo momento pretende-se realizar um levantamento de fontes e documentos, como atas de reuniões, registros de produção, entre outros, dos assentados do São Bento. Esperamos obter, por meio desse recurso metodológico, narrativas e relatos de experiências que envolvam trajetórias pessoais e de vida dos assentados e, que, de modo geral, contribua para a apreensão dos objetivos pretendidos neste estudo.

Além da pesquisa de campo realizada no assentamento objeto deste estudo, aos quais visa, sobretudo, compilar dados e fontes pertinentes ao objetivo proposto, realizar-se-á visita aos arquivos da Comissão Pastoral da Terra (CPT), localizada na cidade de Goiás, bem como aos documentos do Instituto Nacional de Colonização e Reforma Agrária (INCRA) na cidade de Goiânia. A intenção em pesquisar nas instituições mencionadas insere-se no contexto de formação do Assentamento São Bento, uma vez que este obteve o apoio de ambas no que toca à sua criação.

\section{RESULTADOS E DISCUSSÕES}

A produção do espaço no Assentamento São Bento em Heitoraí-GO se faz dentro da lógica desigual de apropriação, diante dessa realidade se percebe nos cotidianos dos assentados várias ações que podem ser apreendidas na condição de rupturas de lógicas que asseguram o binômio capital-estado. 0 plano da vida se fragmenta por vivências traduzidas por diferenças, aqui, se descortina o processo de apreensão do que se trata por cotidiano pautado nas ideias de Lefebvre (2006). A crítica ao plano cotidiano recupera as teses 
que versam sobre o urbano, o rural, a cidade e a modernidade. Para subsidiar essa trajetória de pesquisa se propõe uma investigação interdisciplinar que perpassa os campos da economia, política, sociologia e geografia.

É importante destacar que a pesquisa em curso já possui algumas possíveis resoluções hipotéticas para o problema central que a norteia. Sendo assim, acreditamos que as possibilidades de ruptura ao binômio capital-estado no Assentamento São Bento em Heitoraí, ocorre no plano do cotidiano, nas relações sociais e nas formas de sociabilidades que se criam. Quer seja por meio de um mutirão, traição, troca de dias, feiras, festejos, entre outros; até mesmo no improviso do cotidiano, há um processo de rupturacontinuidade com a lógica da produção capitalista.

\section{CONSIDERAÇÕES FINAIS}

Em termos gerais, o estudo ancora-se sobre o método materialista dialético de análise da realidade dos assentamentos. Nesse propósito, buscaremos por uma assimetria conceitual, sobretudo pautada nas contribuições de Henri Lefebvre, acerca do entendimento das "cotidianidades", das rupturas do binômio capital-estado, bem como das "representações" que caracterizam os dispositivos organizativos dos assentados do São Bento.

O espaço como produtor de significados e representações, sem abandonar outras questões centrais Estado, capital, trabalho, renda da terra, etc. - será um dos conceitos por nós abordados de modo acurado. A partir da compreensão do espaço e de suas temporalidades, o estudo das representações cotidianas dos assentados do São Bento será melhor concatenado.

Em termos gerais, as dinâmicas socioespaciais no Assentamento São Bento demonstra uma capacidade de conexão com as possibilidades no interior do não-possível. Quer dizer que no cotidiano apreendido e capturado pelo capital-estado, emerge o possível, o efêmero, o improviso, etc. É desse contexto que se evidenciam as sociabilidades que estão vivas no cotidiano de cada assentado; nos meios e fins da vida diária, em que em um instante subsistem formas variadas de se estabelecer relações sociais diversas.

\section{REFERÊNCIAS}

[1] BERGAMASCO, Sônia Maria Pereira. O Que São Assentamentos Rurais. São Paulo: Brasiliense, 1996.

[2] CASTILHO, Denis. "Tempo do espaço, tempo da vida: uma leitura socioespacial de Heitoraí". Goiânia: Ellos, 2007.

[3] INCRA. Superintendência Regional / SR - 04 GOIÀS. Divisão de Assentamentos. Goiânia, 1997.

[4] JUNIOR, Caio Prado. Formação do Brasil Contemporâneo. 7 ed. São Paulo: Brasiliense, 1963.

[5] LEFEBVRE, H. La presencia y la ausencia: contribución a la teoría de las representaciones. México. Fundo de Cultura Econômica, 2006.

[6] LEITE, Sérgio. Impactos dos Assentamentos - um estudo sobre o meio rural brasileiro. São Paulo: UNESP, 2004.

[7] LIMA, Moura. Veredão: contos regionais e folclóricos. Gurupi: Multgraf Araújo, 1999.

[8] MARTINS, José de Souza. "Os Camponeses e a Política no Brasil: as lutas sociais no campo e seu lugar no processo político". 4. ed. Petrópolis, RJ: Vozes, 1990.

[9] NASCIMENTO dos Santos, L. et al. (orgs.). Uma pequena viagem pela história de Heitoraí. Heitoraí: Escola Estadual Olavo Costa Campos, 2006.

[10] PESSOA, Jadir de Morais. “A Revanche Camponesa”. Goiânia: Editora da UFG, 1999.

[11] SCOPINHO, Rosimeire Aparecida. Processo Organizativo de Assentamentos Rurais: Trabalho, Condições de Vida e Subjetividade. São Paulo: Anna Blume, 2012.

[12] SILVA, Valtuir Moreira da. "Itapuranga e a (Re) Invenção da História”. Goiânia: Vieira, 2008.

[13] SPAROVEK, Gerd. A Qualidade dos Assentamentos da Reforma Agrária. São Paulo: Páginas e Letras Editora e Gráfica, 2003. 


\section{Capítulo 6}

Neoliberalismo, Território e a Região Metropolitana de Manaus - Nos entremeios de uma "regiâo incomum" e o comum como princípio da geopolítica da metropolização

\section{Susane Patrícia Melo de Lima}

Tomando Manaus como referência metropolitana, ela agrega em si o maior contingente demográfico do Estado do Amazonas, tendo como referência os dados oficiais do IBGE, é concentradora não somente da população, como das riquezas e das decisões políticas. Em razão da presença de um polo industrial em seu território, ela "conecta a redes mundiais de produção e circulação de bens e mercadorias com grau relevante de especialização, torna-se, a partir desse empreendimento, um "nó" na rede mundial de cidades.

Justifica-se tomar este recorte territorial como análise, pela sua condição de existência, do ser uma região metropolitana, tendo como enfoque que a RMM logra o status, sem, contudo possuir autonomia política em relação à necessidade de ações integradas, sem experiências de cooperação e ação conjunta envolvendo as municipalidades pertencentes ao recorte pretendido. 


\section{INTRODUÇÃO: O RECORTE ESPACIAL}

Análises concernentes a Região Metropolitana de Manaus/RMM emergem não como prospecção, mas após ter seu recorte territorial institucionalizado - posto que espacialmente não se evidenciavam as características para tal regionalização - o que implica mencionar logo de início, que aqui se tratará de uma região metropolitana oriunda de decisão política que antecede às dinâmicas espaciais inerentes as mesmas, ou seja, uma nova racionalidade territorial institucionalizada, mas não metropolizada.

O novo espaço geopolítico no estado do Amazonas se estabelece a partir da Lei Complementar no 52 de 30 de maio de 2007, instituindo a RMM composta por sete municípios, a saber, Careiro da Várzea, Iranduba, Itacoatiara, Manaus, Novo Airão, Presidente Figueiredo e Rio Preto da Eva, e neste mesmo ano, pela Lei Complementar no 59 de 27 de dezembro de 2007, inclui-se o município de Manacapuru a RMM. Em 30 de abril de 2009, sob a Lei Promulgada no 64, acresce-se a região metropolitana os municípios de Autazes, Careiro, Itapiranga, Manaquiri e Silves, totalizando 13 municípios no novo recorte territorial ${ }^{5}$, compreendendo uma área territorial de $127.119 \mathrm{~km}^{2}$ (Figura 1).

Esse novo paradigma "urbano-metropolitano"6 institucionalizado, apresenta características metropolitanas (LENCIONI, 2006) rarefeitas, com grande extensão territorial e a metrópole Manaus, caracteriza-se por ser concentradora não somente da maior parcela populacional metropolitana, mas também do dinamismo econômico, político e ideológico.

Figura 1 - Configuração territorial da Região Metropolitana de Manaus

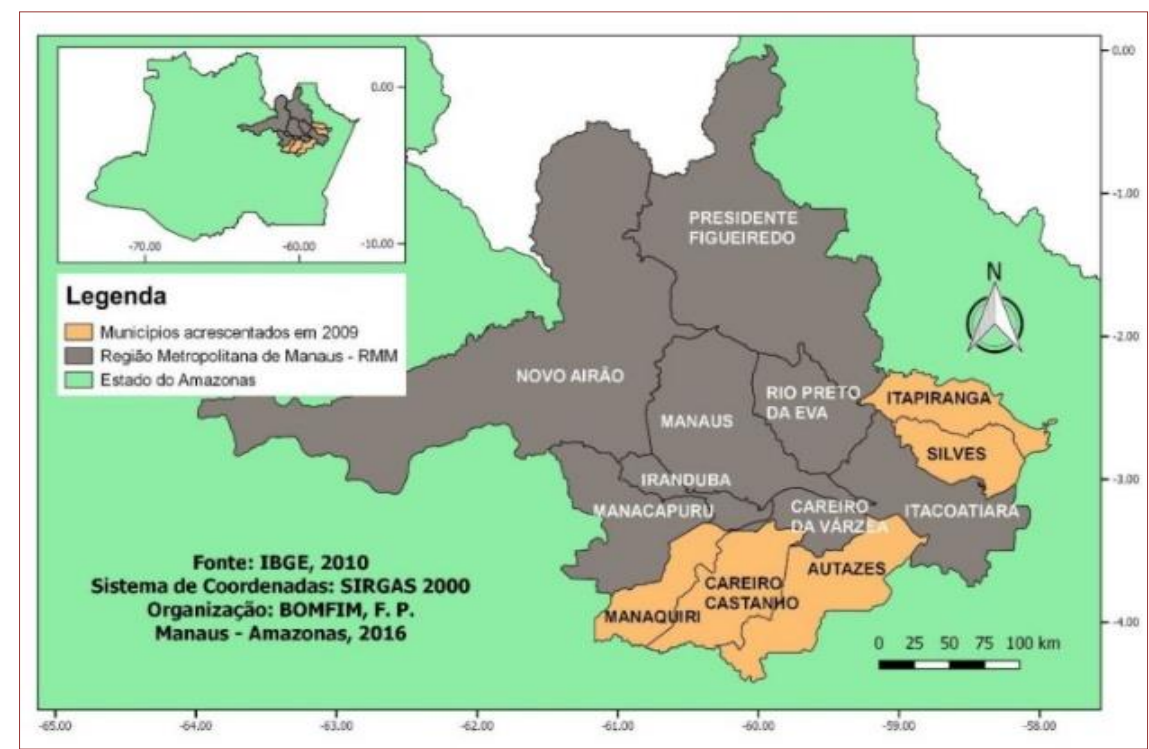

5 Considera-se a existência de um embate entre a Assembleia Legislativa do Estado do Amazonas/ALEAM, e a Secretaria da Região Metropolitana de Manaus/SRMM, que fez com que em 2010 o Tribunal de Justiça do Amazonas julgasse inconstitucional a Lei № 64/2009, que acrescentava os últimos cinco municípios à RMM, todavia, em vigor, a Lei permitiu a agregação dos mesmos com as mesmas prerrogativas dos demais municípios, ambos compondo a RMM (http://www.ale.am.gov.br/2011/10/19/judiciario-mantem-lei-que-inclui-municipios-na-rmm/).

6 Expressão utilizada aqui para evidenciar que os processos podem ocorrer simultaneamente, e não somente sucessivamente, como uma pós-urbanização (FERRIER, 2001), ou seja, pelo entendimento de que a metropolização pode ser ou não uma fase do desenvolvimento urbano, sim enquanto um estágio mais avançado ou uma continuidade da urbanização, e não, por serem essencialmente de natureza diferente. Uma coisa é processo de metropolização do espaço, outra coisa é institucionalização de regiões metropolitanas. A primeira se dá por processo espacial, "desconhece vontades políticas", a segunda por ato político decisório de criar, instituir, "como expediente para o planejamento territorial" (LENCIONI, 2006, p.56). 
Convém mencionar, que as características próprias da região amazônica (humanas e naturais superlativas), aliadas as características próprias da RMM, tão questionadas por suas dessemelhanças complexas, evidenciam a necessidade de compreensão de como este fato metropolitano político se estabelece, e sendo ele fato, é passível de leituras e interpretações por quem a analisa, de modo que é possível apontar que a dimensão política desconsidera a realidade socioespacial (LIMA, 2014).

A realidade metropolitana é presente no território nacional desde o início da década de 1970, em maior ou menor grau ela se espraia pelo território nacional de maneira não homogênea, e especificamente a RMM, esta passa a ser vista segundo o grau de ausência de elementos metropolitanos, de precariedade e/ou de inexistência de serviços básicos potencialmente comuns entre os municípios que a integram, sobretudo quando se pensa que a proposta de criação de regiões metropolitanas visa, conforme a Lei Complementar № 14 de 08 de junho de 1973, o planejamento integrado do desenvolvimento econômico e social; saneamento básico - abastecimento de água, rede de esgotos e serviços, bem como limpeza pública; uso do solo metropolitano, transporte e sistema viário; produção e distribuição de gás combustível canalizado; aproveitamento dos recursos hídricos, controle da poluição ambiental, entre outros serviços de competência do Conselho Deliberativo ${ }^{7}$. Ao rigor da palavra, e por força do conceito, a região era para manter serviços comuns, inclusive o aliar-se em consórcios voluntários.

Para tratar as atipicidades da RMM em relação às demais regiões metropolitanas institucionalizadas antes desta, considera-se desde o papel de Manaus como metrópole até a configuração da região metropolitana com seus treze municípios, com dimensão territorial expressiva ante a baixa densidade populacional, baixa intensidade de fluxos ante as demais regiões metropolitanas brasileiras, entre outras atipicidades. Manaus e sua região metropolitana apresentam-se como superlativas em polos extremos, transitando entre os pares dialéticos de grandeza e pequenez, carência e abundância; existência e ausência, o ser e o não ser, o ter e o não ter, o poder e o não poder, em um contexto que alude Manaus com perfil de metrópole, mesmo antes da institucionalização, exercendo função de comando, de direção e de força política, mantendo uma condição primaz ao longo de sua geo-história de expansão urbana face aos demais municípios do estado.

Tomando Manaus como referência metropolitana, ela agrega em si o maior contingente demográfico do Estado do Amazonas, tendo como referência os dados oficiais do IBGE ${ }^{8}$, é concentradora não somente da população, como das riquezas e das decisões políticas. Em razão da presença de um polo industrial em seu território, ela "conecta a redes mundiais de produção e circulação de bens e mercadorias com grau relevante de especialização, torna-se, a partir desse empreendimento, um "nó" na rede mundial de cidades. Essa característica também é reveladora do perfil de metrópoles e da metropolização regional" (SANTOS; SOUSA; LIMA, 2018, p. 111). No contexto urbano-regional Manaus se destaca com características metropolitanas, enquanto o seu entorno metropolitano não é metropolizado (LIMA, 2014), expressando um território fragmentado, não coeso, disperso do ponto de vista político - sem gestão metropolitana comum - e do ponto de vista físico - a distância geográfica com baixa intensidade de fluxos.

Justifica-se tomar este recorte territorial como análise, pela sua condição de existência, do ser uma região metropolitana, tendo como enfoque que a RMM logra o status, sem, contudo possuir autonomia política em relação à necessidade de ações integradas, sem experiências de cooperação e ação conjunta envolvendo as municipalidades pertencentes ao recorte pretendido. Enfatiza-se que existem questões comuns que não se equacionam na esfera municipal, como saneamento, transporte público, saúde, mas o que se põe é a busca por caminhos que permitam ações positivas, mediadas por projetos integrados e uso adequado dos recursos públicos e nestes casos, "o planejamento destas regiões deve criar mecanismos que não só fortaleçam os municípios e as instituições, mas procurem garantir a cidadania. Acima de tudo, um planejamento que traga integração social e territorial com equidade" (LENCIONI, 2006, p.56).

O desafio geográfico da análise extrapola o imbróglio do se ter ou não uma região metropolitana, do se ter ou não um processo de metropolização, do se ter ou não características metropolitanas, espaços metropolizados ou metropolitanos. 0 "xis da questão" está em analisar as lógicas envoltas no processo,

\footnotetext{
${ }^{7}$ Conforme a Lei Complementar no 14/1973, o Conselho Deliberativo (órgão de gestão da região metropolitana) é responsável por promover a elaboração do Plano de Desenvolvimento integrado da região metropolitana e a programação dos serviços comuns; e ainda, coordenar a execução de programas e projetos de interesse da região metropolitana, objetivando, sempre que possível, a unificação quanto aos serviços comuns. Após a Constituição de 1988 os Estados Federados são autônomos para instituírem regiões metropolitanas.
}

${ }^{8}$ A estimativa populacional do Instituto Brasileiro de Geografia e Estatística/IBGE, em 01 de julho de 2018 era de que o Estado do Amazonas possui 4.080.611 habitantes, dos quais em Manaus estão 2.145.444 habitantes. 
não apenas pelo viés da lógica do capital que avilta a reprodução constante do capitalismo desencadeando sempre novas lógicas para sua manutenção, mas a partir do neoliberalismo como racionalidade, como uma governamentalidade que traz à tona embates desta natureza, ou são geradores de embates maiores, não somente do ponto de vista do território, mas na ótica das subjetividades.

\section{A RMM E O ESTADO DA ARTE}

Que região metropolitana é essa? Qual a racionalidade para o novo território?

Caracterizada como incomum pela ausência de características metropolitanas ${ }^{9}$, a Região Metropolitana de Manaus tem sido foco de análises que apontam desde a sua dimensão territorial superlativa, até as relações que se imbricam para dar ênfase ao processo de metropolização do espaço. Trata-se de pensar uma região metropolitana institucionalizada, com uma metrópole em evidência e uma região por se evidenciar, um contraponto em relação às primeiras regiões metropolitanas brasileiras da década de 1970, ou em relação às preocupações recentes, que devido a falta de normatização, há no Brasil regiões que não possuem metrópole, e ainda metrópoles sem uma região, ambas legalmente instituídas, bastando que os estados federados as tornem e indiquem os municípios que as integrarão. Com o aval do novo marco regulatório, o Estatuto da Metrópole, oriundo da Lei Federal n. 13.089, de 13 de janeiro de 2015, os estados continuam tendo autonomia na formação de regiões metropolitanas.

Considerando a especificidade da RMM, a mesma recebeu análises que permitem reflexões acerca de seu contexto e conteúdo metropolitano, da própria manifestação fenomênica do que se impõe como o "novo" na busca pelo entendimento das relações mais atuais entre cidade, região e território, das relações da totalidade social e suas instâncias, social, política, econômica e cultural. Tais análises transitam entre tipologias e interpretações, verdadeiras leituras, mediante a racionalidade daqueles que a interpretaram a partir da realidade territorial e socioespacial que se estabeleceu e vem se dinamizando face aos processos. Leituras que emanam dos entremeios do real e da realidade são significativas, indicadoras de que qualquer posição assumida ou leitura desse recorte territorial analítico, a RMM, possui um caráter coletivo de construção das ideias, dando significado e significância aos que dão origem intelectual a qualquer produção que se ache também um desenvolvimento de ideia ou mesmo uma nova produção, isso porque "as ideias também têm um caráter coletivo de produção e desenvolvimento" (SANTOS 2015, p.21). Isto posto, a realidade metropolitana se manifesta com diferentes formações e com características que se distinguem entre si, com repercussões particulares, distintas, que em alguns enlaces tem similaridades por possuírem a mesma lógica. De acordo com Santos (2015) tais particularidades apresentam reflexos na configuração das metrópoles, na relação com o seu entorno regional e implicações nas políticas de planejamento e gestão dos espaços, e que ao contrário do que se possa pensar, não possui como característica principal a homogeneização, mas a coexistência de diferenciações, inclusive no plano subregional, quando se pensa nas regiões metropolitanas da Amazônia Brasileira.

A RMM, enquanto um novo recorte territorial geopolítico no estado do Amazonas pode ter como base os estudos o processo de urbanização da Amazônia, com olhares que partem da perspectiva macro à micro, que seria a RMM. Trindade Júnior (1998), por exemplo, analisou a reestruturação metropolitana de Belém enquanto um processo que levou a metrópole a tomar nova forma urbana a partir dos impactos das políticas desenvolvimentistas e da integração regional ao restante do território nacional, aludindo como conseguinte uma Amazônia metropolitana a partir da realidade de Belém, mas considerando tessituras a respeito de Manaus. Outros trabalhos fazem menção desta Amazônia metropolitana, atentando a natureza da urbanização na Amazônia metropolitana (TRINDADE JR., 2000), aos grandes projetos e a metropolização na Amazônia tendo como referência Belém e Manaus (TRINDADE JR.,2006), a

\footnotetext{
${ }^{9}$ Neste texto as características metropolitanas são compreendidas como indica Lencioni (2003; 2006; 2013) que a metropolização imprimi marcas metropolitanas ao território, alterando estruturas pré-existentes, seja na metrópole ou não, são estas: a grande intensidade de fluxos de pessoas, mercadorias e capitais, do crescimento das atividades de serviços e de cada vez maior demanda do trabalho imaterial, da concentração de atividades de gestão e administração, da cada vez maior utilização de tecnologias de informação e comunicação, de grande variedade de atividades econômicas com maior concentração de serviços de ordem superior, da exacerbação da associação entre o capital financeiro, promotores imobiliários e da indústria da construção, da produção de um modo de viver e de consumo que se espelha no perfil da metrópole. "Essas características fazem com que não só as práticas sociais, mas, inclusive as identidades dos lugares fiquem sujeitas aos códigos metropolitanos" (LENCIONI, 2003, p. 35). Nem sempre ocorrem em sua totalidade, é mesmo processual e com intensidades diferenciadas em cada território.
} 
diferenciação territorial como desafio às políticas urbanas considerando a diversidade na Amazônia (Urbanodiversidade) (TRINDADE JR.,2011).

Para enfatizar a realidade empírica da RMM, a revisão da literatura referencial permite enunciar relevantes concepções. Nogueira (2011, p. 175) aponta a competência que ação política tem de "fazer geografia, ou seja, de criar territórios necessários para o exercício da gestão estatal", segue apontando a criação da Região Metropolitana de Manaus como fruto da política local, uma "invenção geográfica inusitada" (p.175), que serve aos Estados intervirem politicamente nestas aglomerações. Ademais, menciona ainda a invenção da RMM, uma "instituição artificial", sobretudo, se retomar alguns pontos norteadores da Lei Complementar de 1973, ao que tange aos serviços comuns, ou mesmo os problemas comuns aos municípios, visto que pelo fato dos municípios serem dispersos e não ocorrer a conurbação, para Nogueira (2011, p. 187) a "essência da região metropolitana" - não haveria compartilhamentos de demandas comuns, desta feita

Quando duas cidades, no processo de expansão urbana, aproximam ou unem suas malhas, ocorre a necessidade de os executivos municipais definirem ações comuns tais como a organização do abastecimento de água e rede de esgoto, bem como a própria limpeza pública; o transporte urbano também deve estruturar sua malha viária com vista a atender os municípios envolvidos. Ainda o próprio uso dos recursos hídricos e controle da poluição deles e a regulamentação do uso do solo. A distância entre os núcleos urbanos da Região Metropolitana de Manaus exime qualquer município dessas preocupações, uma vez que não há compartilhamento de problemas gerados porque não há conurbação (NOGUEIRA, 211, p. 187).

Nogueira (2011) afirma ainda que o espaço urbano pode ser produzido por recortes territoriais estabelecidos pelo poder estatal, e no caso específico da RMM, essa entidade territorial tem caráter administrativo e não político, na medida em que sua gestão se faz por um conselho delegado e não por representantes da população. $\mathrm{O}$ autor encerra enfatizando que muito embora o perfil populacional Manaus "não pode rigorosamente constituir uma região metropolitana, pois como exposto, os fluxos intermunicipais, em razão das distâncias - e isso é uma questão de fricção - não possuem densidades que caracterizam, que marcam as regiões metropolitanas no Brasil" (NOGUEIRA, 2011, p. 188 ).

Ao mencionar a premissa da conurbação autores como Sousa (2013), Lima (2014) e Santos (2015) tratamna também na perspectiva da formação de regiões metropolitanas aludindo que "a RMM é resultante mais de uma vontade política do que de um processo espacial" (SOUSA, 2013, p. 65) ou que a RMM é singular pelas suas dimensões e processos, e mesmo considerando que nem todas as regiões metropolitanas brasileiras instituídas na década de 1970 apresentavam-se totalmente conurbadas - como a Região Metropolitana de Fortaleza/RMF, com intensas trocas, fluxos e compartilhamentos das políticas públicas mas de certo tanto uma quanto a outra seguem o perfil da lógica da reprodução do capital (SOUSA, 2013) e a RMM, "por sua dimensão territorial superlativa, esses processos da metrópole em relação aos demais núcleos que viriam a compor sua região metropolitana eram bem menores que em qualquer outra RM já instituída no país" (LIMA, 2014, p. 80), esse fato evidencia o cunho político da institucionalização, cuja realidade socioespacial metropolitana seria "produzida a partir daí, pela legitimidade jurídica e pelos discursos produzidos ideologicamente para tal" (LIMA, 2014, p.80).

Já Santos (2015), menciona que, historicamente, uma região metropolitana foi percebida por sua forma urbana, ou seja, pela aproximação das malhas urbanas entre distintas cidades, a unificação do ponto de vista físico, a conurbação. Porém, mais recentemente observa-se "a existência de espaços metropolitanos que não têm como única característica a conurbação. Em alguns casos, a unidade física não é mais o elemento mais marcante de aglomerações metropolitanas contemporâneas" (SANTOS, 2015, p. 35), reconhece-se assim uma mudança no perfil metropolitano contemporâneo, sendo necessário ir além da análise do surgimento, mas "compreender os elementos constitutivos dessa nova forma metropolitana, identificada mais pela concentração e disseminação de fluxos diversos do que pela unidade física" (SANTOS, 2015, p.35), e sim, isto implica nas concepções de planejamento e gestão, e o paradigma da governança metropolitana deverá alcançar essas especificidades. Para Santos

É a essa nova forma de espacialização das metrópoles contemporâneas que denominamos "concentração fluida", a aglomeração urbana continua sendo característica do espaço metropolitano, mas não é somente a sua forma compacta ou contínua que a caracteriza como tal. A emergência de uma nova realidade de interdependência global constrói um ambiente propício para as 
mudanças na lógica de estruturação da metrópole contemporânea que extrapolam os limites somente da conurbação entre cidades diferentes e separadas por limites político-administrativos e continuidade socioterritorial [...] A conurbação, portanto, não era, de maneira alguma, expressão da construção de um espaço urbano característico de relações sociais específicas [...] (SANTOS, 2015, p. 39).

Trata-se de uma forma metropolitana que não é marcada pela conurbação ou pela contiguidade espacial, portanto a realidade metropolitana se traduz de outra maneira e com outras características, marcada não pela "contiguidade territorial a sua maior expressão, mas sim a presença de fluxos de natureza diversa em espaços que são contínuos, mas não necessariamente contíguos" (SANTOS, 2015, p. 44). Há que se apontar ainda, alguns postulados teóricos acerca da RMM, em que se preze o processo de metropolização e, como hoje, após doze anos de sua institucionalização se dá sua expressão metropolitana. Deve-se considerar que nem toda unidade institucionalizada como região metropolitana é decorrente de processo de metropolização, a institucionalização pelos estados, sem parâmetros que orientem a definição, relega um perfil heterogêneo as novas regiões metropolitanas, "nem sempre tendo como pólo uma cidade que conceitualmente, possa ser definida como metrópole" (MOURA, 2004, p. 82), o que ocorre em alguns casos, e em outros, extensas faixas territoriais não metropolizadas.

Manaus se configura como metrópole envolta na ação política, na legitimidade jurídica e no discurso ideológico. Desde 2007 vai se expandindo para além de seus limites territoriais, dando origem a primeira "conurbação" da Amazônia Ocidental, configurando a metropolização induzida do espaço via estruturas estatais e expansão imobiliária (LIMA, 2014), e a ponte Rio Negro que objetiva tal processo, bem como, o melhoramento das rodovias, neste caso, a duplicação, capaz de aumentar o fluxo de pessoas, veículos, serviços. 0 contexto analisado por Lima (2014) alude a metropolização em três dimensões, a política, a jurídica e a ideológica, enquanto prática efetiva de construção do metropolizar. Para Lima (2014, p.285) "o ato de instituir uma RM é sempre um ato político. Mas este não ocorre de forma isolada, pois irá necessitar de um marco jurídico que lhe confira legitimidade e poder de ação. Por outro lado, ambos, o político e o jurídico, não prescindem de uma dimensão ideológica, que vai atuar na esfera dos discursos e fornecer suporte para as ações", portanto há que se considerar a imbricação das três dimensões.

Sousa (2013) ao analisar as transformações socioespaciais nos municípios de Iranduba e Manacapuru a fim de conceber as dinâmicas na RMM, atenta ações do Estado, do capital e as condições do espaço urbano-regional aludindo a dimensão política, econômica e social de tais transformações como resultantes dos interesses de diversos agentes que produzem o espaço, bem como das suas relações, seja de cooperação ou confrontação, trata-se de uma inter-relação que se dá de maneira complementar, com interesses que podem ser diferentes, mas em geral, são convergentes. Em relação a criação da RMM e a construção da ponte Rio negro, menciona como ações do governo estadual com propósito de normatizar o uso e ocupação da terra, estabelecendo as estruturas para a produção do espaço urbano-regional nas proximidades de Manaus, e para os dois casos as ações estão associadas aos interesses do capital. Sousa (2013, p. 24) enfatiza que os "investimentos e a maneira como são feitos não estão subordinados às condições técnicas disponíveis, mas às decisões políticas, como é o caso da ponte Rio Negro. Trata-se de uma ação que procura adequar o território às necessidades da produção capitalista". Para Sousa (2013), a RMM foi instituída para a reorganização do espaço urbano-regional, por conseguinte melhor controle da gestão territorial, e a ponte, como possibilidade ou como instrumento da expansão urbana do sistema de transporte, do mercado imobiliário e da ampliação do comércio e serviços e da própria realização da região metropolitana.

Santos (2015) ao analisar as regiões metropolitanas de Belém/RMB, de São Luís/RMSL e de Manaus/RMM, menciona que no caso de Manaus, esta se constitui no espaço metropolitano oriundo da intensidade dos fixos e fluxos nos seus limites municipais. A política metropolitana que se adotou foi a de consolidar uma área metropolitana com vários municípios adjacente a Manaus, em que a realidade metropolitana se estabelece exclusivamente neste. Considera ainda que a RMM "não surge como uma pretensa unidade de gestão dos denominados 'interesses comuns'” (SANTOS, 2015, p. 215) e, portanto, há que se considerar a RMM como estratégia específica para legitimar outros interesses diversos do "comum". É plausível citar que a lógica de funcionamento do sistema de planejamento e gestão da RMM é do governo do estado que dispõe de instrumentos de gestão de grande poder na dinâmica urbanometropolitana "trata-se de uma escolha racional da escala estadual que busca na RMM uma unidade de gestão territorial para suas intervenções" (SANTOS, 2015, p. 221). A RMM serve de apoio para elaboração e execução de políticas de planejamento e gestão metropolitana de Manaus, sem gestão consorciada com os demais municípios, e a construção dos grandes objetos que sustentam a nova dinâmica metropolitana 
pode ser vista "como uma necessidade criada para a conquista do adjetivo 'metropolitano' frente ao projeto de inserção de Manaus no contexto global" (SANTOS, 2015, p.225).

Algumas premissas alicerçadas em experiências coletivas e individuais de pesquisas anteriores ${ }^{10}$, que têm como realidade empírica a RMM, o processo de metropolização urbano-regional ou com desenvolvimento de temas relacionados à realidade metropolitana, apontam poder-se preceituar, que esta apresenta uma reestruturação espacial intensificada por meio das ações do Estado, que vêm alterando um espaço entendido outrora como tipicamente rural, em urbano, agora metropolitano ${ }^{11}$, sobretudo decorrente dos investimentos do capital imobiliário, de prestação de serviços e ampliação do comércio, e da forte ação do poder político estatal, fatos que criam condições para a (re)produção do mesmo, a partir de novas infraestruturas, geradoras de fluxos não existentes anteriormente, pelo menos com tal intensidade.

No principal eixo de alterações no uso e ocupação da terra, a partir da rodovia, da qual o processo de metropolização é condição para sua aceleração, é possível destacar além da metropolização, a urbanização, em direção aos municípios de Iranduba e Manacapuru, ou seja, concomitantemente as características do urbano se coadunam às características metropolitanas, visto que em algumas áreas há uma novidade quanto a alguns aspectos da vida urbana, sobretudo, ao que tange atividades de comércio e serviços, redundando em transformações socioespaciais que trazem uma nova racionalidade ao espaço urbano-regional.

Lima e Sousa (2017) discorrem sobre o papel do Estado, enquanto agente produtor do espaço, e evidenciam que este tem tido uma participação efetiva na organização socioespacial da RMM e, especialmente, nas imediações da Rodovia Estadual AM-070, desenvolvendo ações como agente produtor e regulador, ora investido de presença e ausência do mesmo. As ações são refletidas a partir da instalação de grandes objetos, que são marcas da metropolização na Amazônia ocidental - a indução do processo acontece por meio das obras de grande monta.

Santos, Sousa e Lima (2018) ponderam que a difusão da metropolização na Amazônia brasileira, baseada na realidade empírica de Belém e Manaus, perpassa pelos nexos da relação técnica-espaço-tempo que se evidenciam pela construção dos "grandes objetos urbanos", indutores da estruturação do espaço metropolitano ou propulsores para os arranjos metropolitanos regionais, primeiro Belém, posteriormente Manaus, no qual a produção destes objetos é mais recente, porém de impacto similar, considerando as especificidades de cada uma destas metrópoles. 0 exemplo tão apontado é a ponte sobre o Rio Negro, que advoga a expansão da malha urbano-metropolitana para além dos limites da municipalidade de Manaus, difundindo a metrópole conjuntamente. Para os autores a atual configuração metropolitana passa pela produção dos grandes objetos.

Muito se tem apontado acerca das características próprias das regiões metropolitanas, e para o novo espaço geopolítico, a RMM, menciona-se, sobretudo, a sua diferenciação das demais, desde questões geográficas, que tocam na configuração territorial sem conurbação, redes de circulação de bem, pessoas e mercadorias, até as questões de cunho ambientais, demográficas, políticas e socioeconômicas. A realidade territorial se mostra concatenada a uma racionalidade da esfera política, institucionalizada a partir do viés político e não espacial. Isso implica em uma sequência de desafios que se estabelecem para a realização da RMM, entre os quais, o de gestão que se mescla nas disputas de poder entre os agentes sociais envolvidos, entremeados pela necessidade de cooperação, parcerias e articulação para a solução dos chamados "problemas comuns" ou demandas, ou mesmo articulação para gerir as funções públicas de interesse comum, e não desejando ser concluso e, portanto, ter respostas finais, a inexistente ou fraca identidade

\footnotetext{
${ }^{10}$ Pesquisas realizadas pela autora deste Ensaio Teórico, em conjunto com outros pesquisadores, no âmbito do Núcleo de Pesquisas Urbana e Regional/Npur, da Universidade do Estado do Amazonas/UEA, ambas com financiamento do Conselho Nacional de Desenvolvimento Científico e Tecnológico/CNPq e da Universidade do Estado do Amazonas/UEA, a saber: "Região Metropolitana de Manaus: as transformações socioespaciais na borda sul (20072014)" /CNPq; "Polimorfismo do Labor: mercado de trabalho na Região Metropolitana de Manaus/RMM/Borda Sul" /UEA; "Dinâmicas urbano-regionais na Região Metropolitana de Manaus: uso e ocupação do espaço em Iranduba e Manacapuru" /UEA; "Difusão da metrópole e metropolização na Amazônia: monitoramento e análise das dinâmicas e reestruturações espaciais a partir da Região Metropolitana de Manaus" /CNPq.

11 No eixo da rodovia que se estende saindo de Manaus a partir da Ponte Rio Negro até Manacapuru, o processo de indução à metropolização trouxe nova lógica, nova racionalidade, novo viver, considerando novos fluxos que ali se intensificaram, ampliação de serviços e comercio, expansão imobiliária, assim, rural, urbano e metropolitano se entrelaçam como efeito da metropolização ou simplesmente da difusão do urbano a partir do fenômeno metropolitano.
} 
metropolitana, que se mostra latente desde os municípios mais próximos, até os mais distantes que possuem baixa capacidade de fluidez na rede de circulação.

Convém mencionar que de tudo o que já se mencionou acerca da Amazônia metropolitana, ou da RMM, não se pode apontar um esgotamento, mas a busca de recomeços, novos pontos de partida, novas leituras e interpretações e mesmo apontamentos, posto que o movimento do real salta aos olhos, se evidencia, se impõe revestido de desafios que movem ou motivam sempre novas buscas face a crescente complexidade, parece se fazer necessário decifrá-lo.

\section{DO TERRITÓRIO À REGIÃO, DO NEOLIBERALISMO À METROPOLIZAÇÃO E $O$ COMUM COMO PRINCÍPIO POLÍTICO}

As reflexões teórico-metodológicas aqui apresentadas fazem parte de um movimento do pensar calcado em um arcabouço de discussões, que aludem sobre um processo de metropolização em escalas que variam do global ao local, e neste caso, o local se torna o caso empírico pontual, que se enxerga com especificidades, particularidades, heterogeneidades, mas reifica homogeneidades, generalidades, posto que a lógica do processo é a mesma do global ao local. Parte-se de realidades primeiras, que trazem consigo proposituras do pensar de uma gama de autores, e de certo, é um erro crasso não incluir tantos outros, mas aqui se considera que os apontados corroboram para o enlevo do início da ideia, do pensar, das problematizações que se apresentam quase orbitais por aqui.

Essa abordagem não prescinde a Geografia e suas categorias fundantes, pois um trabalho que se requer geográfico dialoga com a dimensão espacial, são mesmo o fundamento de qualquer análise de escopo geográfico. Conceitos ou categorias que embora ao longo do pensamento geográfico tenham sido "(re)elaborados" por grandes intelectuais geógrafos - em decorrência da formação científica e do avançar das formas de pensar, quer sejam, lastreados pelos métodos, pelas correntes de pensamento (tendências doutrinárias) e/ou matrizes teóricas - são caros a esta ciência e, portanto, não se pretende desconsiderar. Aqui, território e região serão primordiais, bem como os processos, de regionalização e de territorialização como mediadores da metropolização. Convém retomar o que logo acima fora posto, para justificar as escolhas, que os conceitos geográficos muitas vezes demandam revisões mais densas em razão das suas transformações ao longo da história do pensamento geográfico, todavia, nesse momento não nos ateremos às múltiplas abordagens de tal trajetória, mas adotaremos reflexões, e estas, aludem posicionamentos que se acredita, poderem iluminar o entendimento dos processos no presente. Não se pretende com isso o reducionismo dos conceitos, a vulgarização dos mesmos, nem limitar seus usos trazendo visão parcial, trata-se mesmo de uma questão de escolha e de limite imposto pela envergadura textual proposta.

No entendimento de que o "novo" e o "velho" coexistem elencando complexidades, lê-se a região como Gomes (2000) - dada as suas interpretações desde a geografia clássica com Paul Vidal de La Blache e sua região natural - para o qual a geografia deve buscar "nos diferentes usos correntes do conceito de região suas operacionalidades" (GOMES, 2000, p. 50), sendo um conceito que "tem implicações fundadoras no campo da discussão política, da dinâmica do Estado, da organização da cultura e do estatuto da diversidade espacial" (GOMES, 2000, p. 52), e por esta apreensão região se equipara ao território de onde se manifestam as relações de poder, o modo de produção e as múltiplas relações dos agentes sociais que ora se articulam em redes, que dão sentido enfim, à regionalização. Oliveira (1981) fundamentado no arsenal marxista entende a regionalização a partir do modo de produção e como este impulsiona estruturas sociais, culturais dando sentido a organização do espaço imbricada ao social, ao político e a região. Para este autor, a região é oriunda de diferentes lógicas de reprodução do capitalismo e o papel da política é definidor na análise regional. Oliveira (1981) parte de determinações regionais, mas chega às relações de poder, portanto define determinações territoriais, impondo o território.

Castro (1994, p. 158) retoma o tema região como base territorial do regionalismo em nível nacional, para ela a importância da "escala planetária na organização da economia, das finanças, das redes de poder tem, paradoxalmente, reforçado a importância das decisões nas escalas regionais e locais" visto a complexidade do real que se impõem, sendo que a escala é entendida não como medida, pois ela não fragmenta, mas integra, assim a escala "não supõe hierarquia, não podendo haver qualificação valorativa para diferentes escalas" (CASTRO, 1994, p. 160). Não se pretende discutir escala como categoria analítica, mas mencionar em conformidade com Castro (1994) que dada a realidade complexa do mundo contemporâneo, multiescalarmente, o recorte espacial é muito pertinente, porque coloca em evidência relações, 
fenômenos, fatos, assim, ele supõe a região constituída de práticas espaciais em um território, e a região deriva das

possibilidades explicativas dos processos de transformação do espaço e dos atores mais destacados das mudanças. Na realidade, a identidade sócioespacial, o espaço do cotidiano, o espaço da participação, da mobilização e da decisão política, o espaço da administração pública e outros mais definem novas questões para investigação e estabelecem o desafio metodológico da escala dos fenômenos que dão sentido ao território regional (CASTRO, 1994, p. 162).

Desta forma se evidencia a forte conexão entre região e território, pois a primeira enseja uma reflexão na arena política, esta relação em espaço delimitados administrativamente refletem as forças dominantes, assim "a região se torna o locus da elaboração política, cuja materialização se faz no formato das relações sociais no seu território" (CASTRO, 1994, p. 167). A globalização traz a tona o caráter particular da região e possibilita recortes regionais diversos, porém preservando especificidades, características locais dentro de um sistema global de processos, se dá em múltiplas escalas, mas suas particularidades se evidenciam pela regionalização, configurando identidades regionais, ou mesmo, regionalismos. Para Lencioni (1999) o conceito de região segue vinculado à ideia de parte de um todo, como no caso das regiões metropolitanas, que são parte de um todo dentro de um sistema complexo de processos universais que lhes dão um caráter de específico, um caráter particular a cada região. A região é uma realidade encarada com as lentes do observador, uma criação intelectual. Região e território, em que se diferenciam? Ambos possuem ampla conexão de ideias, parecem mesmo possuir limites tênues, talvez possa se admitir como ponto pacífico na geografia.

O território, categoria de ênfase na Geografia Política, é a base espacial das ações do Estado, que ganha concretude, segundo Sposito (2004) ao ser associado à sociedade em termos jurídicos, políticos ou econômicos. Para Sposito

0 território é fonte de recursos e só pode ser compreendido quando enfocado em sua relação com a sociedade e suas relações de produção, o que pode ser identificado pela indústria, pela agricultura, pela mineração, pela circulação de mercadorias etc., ou seja, pelas diferentes maneiras que a sociedade se utiliza, para se apropriar e transformar a natureza (SPOSITO, 2004, p. 113).

0 território é fundamentalmente um espaço definido e delimitado por e a partir das relações de poder, porém saber quais os recursos de uma dada área, o que se produz, quem produz, ou quais as relações afetivas e identitárias de um grupo são relevantes, mas não cruciais para a compreensão de um território, e sim quem domina ou influencia, pois o território é um instrumento do exercício do poder, definindo o espaço sob dois ingredientes, o espaço e o poder (SOUZA, 2000).

Assim, o território apresenta-se com maior amplitude que a região, concebida como um recorte espacial, ou mesmo, como supramencionado, uma construção social, sob a ótica particular do pesquisador, carrega em si particularidades que as diferenciam das demais partes do todo ou do próprio território. A região é produto da regionalização independente da escala geográfica em que se dá, é passiva de constantes alterações. Haesbaert (2017) ao tratar de limites e fronteiras com vistas aos processos de regionalização e territorialização na metrópole, associa a região com o limite ou a delimitação espacial, mais abstrata ou analítica, e o território com a ideia de fronteira, relacionando-o de forma mais direta com as práticas sociais, sobretudo, as práticas políticas. Assim, a concepção de regionalização se imbrica a um processo analítico/normativo, dando enlevo as diferenças espaciais que delimita os espaços, seja por processos de divisão mais dedutivos ou por agrupamentos mais indutivos, o que implica em aceitar uma regionalização como delimitação do espaço, considerando suas diferenças ou mesmo desigualdades em diferentes escalas.

Assim como a região e a regionalização, o território e a territorialização, são vistos por Haesbaert (2017), sob as perspectivas, analítica, prática e normativa. A primeira é proposta do pesquisador, a segunda, o uso do senso comum, e a terceira, aplicação pelos planejadores. Para o autor, a territorialização é definida "como um processo de exercício (tático-estratégico) de poder que faz uso e/ou produz diferenciações (ou também des-articulações) espaciais" (HAESBAERT, 2017, p. 135). Destarte, a regionalização é construtora de limites muito mais analíticos e normativos do que vividos, e a territorialização, estabelecedora de fronteiras, muito mais no campo sociopolítico do que no campo analítico (HAESBAERT, 2017) e, ambos, se empregam contemporaneamente, cada vez mais complexos, sumariamente quando se vislumbra o cenário do Estado capitalista. 
Para considerar o processo de metropolização sublinha-se que o movimento do pensamento se pareia ao de Sandra Lencioni (2017a) que trata a metropolização a partir de uma lógica que não é coincidente somente com as regiões metropolitanas, abrangendo espaços não pertencentes a uma região metropolitana instituída, metropolização do espaço para além da metrópole e de sua região, fato que exprime um novo momento da história da urbanização, em que o processo de metropolização é entendido como a condição atual da urbanização.

Sandra Lencioni (1998, 2003, 2006, 2011a, 2011b, 2013, 2015b) aponta o entendimento da metropolização do espaço, como um processo que imprimi ou confere ao território características que em dado momento eram exclusivas da região metropolitana, tais características fazem com que as práticas sociais, as identidades dos lugares fiquem sujeitas aos códigos metropolitanos, "os avatares dos novos valores e signos da sociedade contemporânea" (LENCIONI, 2003, p.35). Seria mesmo um momento de pensar a superação do urbano pelo metropolitano, relações que ganham corporificações e redefinem o território metropolitano. Para Lencioni (2006a, p.73) a metropolização é "uma metamorfose do processo de urbanização" ou "uma segunda natureza da urbanização" (LENCIONI, 2015a, p.37), e isso modifica, transforma as cidades pequenas e médias do entorno metropolitano (LENCIONI, 2006a).

Ao passo da interpretação de Sandra Lencioni para a metropolização, Leopoldo (2014 e 2015) traz como referência que a metropolização indo além da metrópole pode estar em outros lugares, inclusive no rural, agrário ou pequenas aldeias, espaços não metropolizados ainda, para ele não somente a paisagem metropolitana apresenta a presença de objetos metropolitanos que irão configurar a metropolização "mas também os lugares aonde chegam com mais ou menos velocidade e intensidade as representações e valores metropolitanos, emanados da metrópole, que crescentemente ganham a totalidade do espaço mundial. Esses espaços não são necessariamente metropolitanos, mas fazem parte da lógica metropolitana" (LEOPOLDO, 2018, p 93).

Essas lógicas parecem estar a serviço do capital, quando "criar metrópoles", ou "inventar regiões metropolitanas" "induzir a metropolização" indicam uma geopolítica de negociação da metropolização, posto que "a metropolização se tornou também um negócio", a política do Estado vira política do espaço ampliando o poder da metrópole (LEOPOLDO, 2018, p.93). Essa racionalidade parte indubitavelmente, no Brasil, da redemocratização neoliberal e depois as políticas desenvolvimentistas, que ensejaram na formação das Regiões Metropolitanas, enquanto aglomerados, e ainda ampliaram o poder das metrópoles na subjugação do entorno próximo e distante. A metropolização como fruto das políticas neoliberais mundiais que chegaram ao Brasil na égide do capitalismo industrial, institucionalizando regiões metropolitanas, segue esta lógica contemporaneamente, com uma capacidade de autofortalecimento, pela sua lógica normativa global. A RMM é fruto da lógica neoliberal que extrapola a lógica do capital e alcança os níveis da subjetividade.

As chamadas ideias neoliberais, segundo David Harvey (2008) apresentam grande difusão após 1973, após a recessão dos países imperialistas, posterior a quase trinta anos de avanço econômico. Para os neoliberais a crise era associada ao excessivo poder dos sindicatos, dos movimentos de trabalhadores, que ao garantirem expansão dos seus direitos desgastaram os lucros das empresas, assim, o Estado neoliberal se propôs a retirar o poder dos sindicatos, diminuir gastos com as causas sociais e reduziria a sua intervenção na economia. É Harvey (2008) ainda que aponta as políticas neoliberais como um projeto de classe para restaurar o poder das elites e da acumulação do capital, considerando a propriedade privada como a base da liberdade individual. Neutralizar a esquerda em todo globo e combater ideias comunistas, foram racionalidades no neoliberalismo, ou seja, a ideia neoliberal é a ideologia do capitalismo financeiro, segundo Moraes (2001, p.11), "a era da riqueza mais líquida, a era do capital volátil - e um ataque às formas de regulação econômica do século XX, como socialismo, o keynesianismo, o Estado de bem-estar, o terceiro mundismo e o desenvolvimento latino-americano", cria-se assim condições para a reprodução da forma mercadoria em todas as esferas da vida. Para Harvey (2008) o neoliberalismo

[...] propõe que o bem-estar humano pode ser melhor promovido liberando-se as liberdades e capacidades empreendedoras individuais no âmbito de uma estrutura institucional caracterizada por sólidos direitos a propriedade privada, livres mercados e livre comércio. 0 papel do Estado é criar e preservar uma estrutura institucional apropriada a essas práticas; o Estado tem de garantir, por exemplo, a qualidade e a integridade do dinheiro. Deve também estabelecer as estruturas e funções militares, de defesa, da polícia e legais requeridas para garantir direitos de propriedade individuais e para assegurar, se necessário pela força, o funcionamento apropriado dos mercados (HARVEY, 2008, p. 12). 
Assim, preconizou-se o advento do neoliberalismo, que sendo hegemônico no discurso, afetou a racionalidade, as ideologias, a consciência enquanto movimento do pensamento, em todas as esferas da vida e, impacta às diversas maneiras dos sujeitos interpretarem, viverem e compreenderem o mundo, mormente, porque o capital domina todas as esferas das ações humanas, e estas, passam a ser de domínio do mercado com o neoliberalismo. Seus defensores exercem influência considerável na educação, nos meios-de-comunicação, em instituições financeiras que desempenham a regulação das finanças no globo, bem como, em organismos multilaterais (HARVEY, 2008). Há o predomínio dos individualismos, primando-se pela liberdade individual e a competitividade, o bem-estar social individual se estabelece em detrimento do bem-estar coletivo; afirmam a importância de um mercado hegemônico e a manutenção de um Estado que não intervenção na economia.

O entendimento do neoliberalismo é enfatizado neste ensaio, conforme Dardot e Laval (2016) por meio do qual este não é apenas uma ideologia ou um tipo de política econômica, mas um sistema de normas que ampliou e amplia sua influência a partir da lógica do capital em todas as esferas da vida. Assim,

\begin{abstract}
Além dos fatores sociológicos e políticos, os próprios móbeis subjetivos da mobilização são enfraquecidos pelo sistema neoliberal: a ação coletiva se tornou mais difícil, porque os indivíduos são submetidos a um regime de concorrência em todos os níveis. As formas de gestão nas empresas, o desemprego, a precariedade, a dívida e a avaliação, são poderosas alavancas de concorrência interindividual e definem novos modos de subjetivação. A polarização entre os que desistem e os que são bem-sucedidos mina a solidariedade e a cidadania. Abstenção eleitoral, dessindicalização, racismo, tudo parece conduzir à destruição das condições do coletivo e, por consequência, ao enfraquecimento da capacidade de agir contra o neoliberalismo (DARDOT; LAVAL, 2016, p. 9).
\end{abstract}

O neoliberalismo transforma o capitalismo e transforma profundamente as sociedades, "é a razão do capitalismo contemporâneo" (DARDOT; LAVAL, 2016, p. 17) carrega consigo uma ideia própria de democracia que em muitos aspectos deriva de um antidemocratismo, o sistema neoliberal promove uma entrada na era pós-democrática, e conhecer, bem como analisar a gênese do neoliberalismo é uma condição para sua resistência em escala mundial, sobretudo, sua compreensão é uma questão estratégica universal. Convém mencionar que Dardot e Laval (2016) são enfáticos quanto às políticas neoliberais, posto que para eles, incidem na "forma da nossa existência, isto é, a forma como somos levados a nos comportar, a nos relacionar com os outros e com nós mesmos" (DARDOT; LAVAL, 2016, p. 16) definindo certa norma de vida. Para os autores, o neoliberalismo antes de ser uma ideologia ou uma política econômica é fundamentalmente uma racionalidade, que como tal, estrutura e organiza a ação dos governantes e a conduta dos governados, quer seja uma racionalidade política 12 , uma racionalidade governamental. Julgam que a interpretação marxista, embora sua atualidade, se revela insuficiente ante ao neoliberalismo, não podendo ser reduzido apenas a expansão mercantil e a acumulação do capital, "as interpretações marxistas nem sempre conseguem captar as novidades do capitalismo neoliberal: fechando-se numa concepção que faz da 'lógica do capital' um motor autônomo da história, elas reduzem a história a uma repetição dos mesmos roteiros, com as mesmas personagens vestidas com novos figurinos" (DARDOT; LAVAL, 2016, p. 21).

Compreende-se que o enfraquecimento generalizado decorrente do neoliberalismo, que nega a solidariedade, que opera egoísmos, podem provocar movimentos de reação a fim de ultrapassar o neoliberalismo, pelo desenvolvimento de outra racionalidade, a da capacidade coletiva que faz a prevalência do uso do comum, do autogoverno como coatividade, codecisão, a partir mesmo do princípio do comum. A nova racionalidade, não se requer utópica, mas uma proposta teórica ${ }^{13}$, uma perspectiva ou

$12 \mathrm{O}$ conceito de racionalidade política foi elaborado por Michel Foucault quando discutiu a governamentalidade na obra Naissance de la biopolitique de 2004, no Brasil, Nascimento da Biopolítica, traduzida em 2008. Foucault entende o governo como atividade e não como instituição, como conjunto de técnicas e procedimentos destinados a dirigir a conduta dos homens, e o termo governamentalidade precisa as múltiplas formas dessa atividade pela qual homens que podem ou não pertencer a um governo, buscam conduzir a conduta de outros homens, isto é, governa-los. Assim, chama de governamentalidade o encontro entre técnicas de dominação exercidas sobre os outros e as técnicas de si (DARDOT; LAVAL, 2016, p. 17 e 18).

13 Como proposta teórica talvez apresente algumas limitações, posto que conforme o movimento do pensamento, novas questões podem ser lançadas, novas leituras, inerente a toda análise, que um princípio ou proposta teórica 
modo de pensar dada realidade, uma proposta da política do comum, também fundamentada em Dardot e Laval (2017), quando tratam o comum como um ensaio a revolução no século XXI, concebem que o neoliberalismo e todo seu arsenal de políticas públicas impôs uma via diferente, que resultou em um sistema de normas que se apropria das atividades de trabalho, dos comportamentos, das mentes. Para eles

Esse novo sistema estabelece uma concorrência generalizada, regula a relação do indivíduo consigo mesmo e com os outros segundo a lógica da superação e do desempenho infinito. Essa norma da concorrência não nasce espontaneamente em cada um de nós como produto natural do cérebro: não é biológica, é efeito de uma política deliberada. Com o auxílio do dirigente do Estado, a acumulação ilimitada do capital comanda de maneira cada vez mais imperativa e veloz a transformação das sociedades, das relações sociais e da subjetividade, Estamos na época do cosmocapitalismo, no qual, muito além da esfera do trabalho, as instituições, as atividades, os tempos de vida são submetidos a uma lógica normativa geral que os remodela e reorienta conforme os ritmos e objetivos da acumulação do capital (DARDOT; LAVAL, 2017, p. 12).

O comum se efetiva na esfera da coletividade, ou seja, produto de uma construção política na esfera da coletividade, sendo um princípio que se efetiva nas lutas sociais e culturais em oposição à dinâmica do capitalismo, à tendência de ampliação da apropriação privada e ao Estado empresarial. 0 comum não é a reinvenção da ideia comunista, mas um princípio de embate às práticas do capitalismo, ao comunismo de Estado ou à democracia deste e da "liberdade" neoliberal. É a designação de um regime de práticas, de ações que dão sentido aos movimentos de luta, aos discursos, instituições e pesquisas. "Essas lutas políticas obedecem à racionalidade política do comum, são buscas coletivas de formas democráticas novas" (DARDOT; LAVAL, 2017, p. 19). Em Dardot e Laval (2016; 2017) o projeto revolucionário encontrase no princípio político do comum, que rege toda atividade política. Não podendo ser um objeto, não pode ser confundido com o "bem comum", mas o princípio se faz buscar o objeto, o comum é o princípio que faz buscar o bem comum após deliberado coletivamente, o que se considera aqui como o exercício do poder de decidir de uma dada sociedade, o que pode se constituir em emancipação de modelos capitalistas totalizantes, ou mesmo na possibilidade de exercitar práticas diferentes, geradoras de autonomias e liberdades de ser. Entende-se liberdade e autonomia, grosso modo e sem percorrer outras ideias, em conformidade com Cornelius Castoriadis (1983) que contundentemente enfatiza que

A liberdade numa sociedade autônoma exprime-se por estas duas leis fundamentais: sem participação igualitária na tomada de decisões não haverá execução; sem participação igualitária no estabelecimento da lei, não haverá lei. Uma coletividade autônoma tem por divisa e por autodefinição: nós somos aqueles cuja lei é dar a nós mesmos as nossas próprias leis (CASTORIADIS, 1983, p. 22).

Indubitavelmente, Souza (2000) dialoga com Castoriadis (1983) ao enfatizar que uma sociedade autônoma defende e gere livremente seu território, não é sem poder, o que aliás para o autor seria impossível. Tanto em Castoriadis quanto em Souza, as leituras se imbricam, não propositadamente, mas assertivamente com Dardot e Laval (2017), ao mencionar que como princípio político o comum exige que a participação seja o fundamento da obrigação política, e esta por sua vez, procede inteiramente do agir comum, do compromisso prático que une todos os que elaboram as regram de suas atividades, é mesmo uma relação de coatividade, coobrigação e coparticipação.

Em suma, registra-se a importância de buscar leituras outras que movimentem o pensar em torno de novos entendimentos da lógica territorial hegemônica face realidades empíricas bem diferentes, e às vezes tão díspares. Comumente, quando se pensa na realidade dos estudos acerca das regiões metropolitanas, ou mesmo da Região Metropolitana de Manaus, os tais têm sido compreendidos a partir da lógica e reprodução do capital ante ao processo de metropolização do espaço, plausíveis ante ao neoliberalismo, todavia, o que se alude neste momento são narrativas que busquem novas formas de gestão, que ultrapassem os limites na busca por maior justiça espacial, orientada "para uma possível reapropriação em usos coletivos com base em outros tipos de gestão, que não aquela de cima para baixo, abrindo-se às possiblidades de autogestão" (FERREIRA, RUA E MATTOS, 2017, p. 22).

talvez não dê conta, a partir da realidade que se impõe. Mas essa análise não se requer neste momento, nem se poderia agora pela limitação do próprio modelo textual que, este sim, neste momento, se requer cumpri-lo. 


\section{CONSIDERAÇõES FINAIS: QUANDO O FINAL É, ANTES DE TUDO, UM INÍCIO - A GEOPOLÍTICA DA METROPOLIZAÇÃO NA RMM}

Tudo na metrópole, na cidade, é magnânimo, espetacular e, ao mesmo tempo lamentável. Parece ser muito difícil encontrarmos caminhos. Muitas são as utopias e elas são desejáveis, pois revelam o desejo de uma sociedade melhor (LENCIONI, 2017 b, p.71).

Eis que neste fim, antagonicamente, se nos põe um início, grande potência dos processos científicos, em movimento sempre. Algumas questões podem ser levantadas como problematização da ideia, questionamentos que se põem para dar movimento ao pensamento, todas elas consideram as premissas teóricas antepostas, e resguardam a posição no movimento do pensar.

As políticas neoliberais expressas no pensamento dos autores que discutiram tal configuração no mundo contemporâneo a partir de processos, rupturas, reestruturações e ressignificações do neoliberalismo, apontam que este é a própria ideologia capitalista em ascensão, uma constante reorganização do capitalismo que amplia seu domínio ideológica e politicamente sobre os territórios.

Processos de produção do espaço, como a metropolização aludida neste ensaio, são apontados sob a lógica neoliberal de reprodução do capital, na qual as metrópoles se constituem como centros difusores. Sandra Lencioni (2017b), por exemplo, unida ao pensamento lefebvriano, indica que a metropolização do espaço é um processo que exprime a difusão de características que antes eram exclusividade das metrópoles e suas regiões metropolitanas. É um processo que acentua a homogeneização, a fragmentação e a hierarquia entre os lugares. A metrópole é condição, meio e produto da reprodução do capital, portanto difunde seus códigos, conteúdos, valores, signos e significados a partir da racionalidade capitalista condicionada aos interesses do capital, que tem no Estado um agente poderoso, promovendo a lógica da metrópole contemporânea internamente mais desigual, desumana e predatória, sendo esta metrópole no contexto da globalização produto de uma estratégia de sobrevida do capitalismo, e assim, entende-se, que ela se irradia chegando desde seu entorno próximo ao mais distante.

No entanto, em Dardot e Laval (2016) o neoliberalismo é um sistema de normas que extrapola a ordem da acumulação, da dinâmica do capital enquanto lógica de sua própria reprodução e alcança os níveis mais subjetivos, empregando técnicas de poder inéditas sobre condutas e subjetividades. Apontam os limites do marxismo em que as suas interpretações, por mais atuais que sejam, não dão conta de explicar, posto não irem além da expansão mercantil e do campo da acumulação do capital. Fechando-se a concepção nesta "lógica do capital", como motor de uma história, o capitalismo é sempre idêntico a si mesmo. Eles enfatizam que o neoliberalismo não destrói somente regras, instituições e direitos, mas produz relações sociais, maneiras de viver, subjetividades, normas de vida, impondo aos sujeitos viverem em uma competição generalizada, intimados a uma luta econômica constante uns contra os outros; obriga justificativas quase plausíveis para as desigualdades, muda os indivíduos e os insta a comportarem-se como empresa.

Sob essa perspectiva uma geopolítica da metropolização analisaria a RMM para além da lógica do capital, extrapolando essa fronteira e alcançando os móbeis subjetivos ${ }^{14}$. Na geopolítica da metropolização, não se difundem características espaciais da metrópole, atenta-se aí para a difusão dos modos de vida da metrópole, daquelas que implicam diretamente a vida dos indivíduos do ponto de vista mais subjetivo. A assistência mútua, a cooperação no trabalho em suas diversas formas, as trocas solidárias, o compartilhamento, podem indicar uma geopolítica do comum.

No caso empírico, a Região Metropolitana de Manaus, sua institucionalização não esteve em si mesma, mas subjugada à logica e a dinâmica do capital, seletiva e despótica, trazendo à visibilidade as contradições espaciais desta região. Fora as contradições de ordem espacial, temos contrações de ordem política, de gestão, posto que as regiões metropolitanas, estando sob a tutela dos estados que as criam, portanto, enfrentam limitações na sua governabilidade.

\footnotetext{
14 Embora se reconheça que esses são usurpados por esta lógica. A ideia é incluir o indivíduo na análise como o que sofre diretamente os efeitos das políticas neoliberais, não só pelo desemprego, baixa qualidade de vida, supressão de direitos, inclusive acessos inerentes a vida nas cidades, quer seja o direito à cidade lefebvriano.
} 
Considerando as fragilidades múltiplas de gestão nas regiões metropolitanas e as reais possibilidades de arranjos colaborativos, plurais inclusive, entre os municípios membros, propõe-se uma geopolítica da metropolização para o Amazonas e sua região metropolitana, uma geopolítica com base no princípio político do comum, em que a gestão não seja exclusivamente dependente as ações políticas externas às necessidades locais, mas elencadas pelos interesses da população local, dando enlevo ao lugar. A RMM, não se manifesta (nem se acredita que manifestará) contígua, sua metropolização se evidenciará pela difusão de códigos, significados, características difundidas pela metrópole e não pela lógica de atuação sugerida de compartilhamento ou cooperação de demandas ou problemas comuns. Possivelmente os municípios não partilharão, sobretudo se a visão das políticas públicas metropolitanas como políticas territoriais forem sempre mediadas pela inter-relação ou interdependência de problemas que demandem soluções integradas pelo plano da materialidade, visto que nesta realidade empírica as relações mediadas pelo plano da imaterialidade podem ser mais impactantes, como ações, planos, programas político-sociais específicas, por exemplo. No entanto, no plano da materialidade, a biodiversidade se constitui como o nexo exponencial de compartilhamento entre os municípios da RMM. Rios e floresta se unem, e ante a relação sociedade-natureza têm-se os entremeios das necessidades de partilha dos grupos que compõem o recorte espacial. Rios e florestas conurbam os espaços que se tornam contíguos não por fortes processos de urbanização, como se costuma identificar tradicionalmente em regiões metropolitanas. Aqui se tem a dimensão de que uma geopolítica da metropolização que extrapole características do urbano das grandes metrópoles e agregue às questões ambientais, se fazem necessárias.

A partir de uma geopolítica do comum é possível concatenar relações de fortalecimento entre os municípios, com a efetiva participação da população, com atores locais exercendo a primazia nas ações nos territórios, assim a geopolítica do comum será possível por meio de instituições locais, construídas em comum, que se voltem ao comum como um princípio de atividade política ${ }^{15}$ constituído pela possibilidade de deliberação, julgamento, decisão e aplicação das decisões, quer seja uma substituição das condições produzidas pela lógica da acumulação capitalista em uma geopolítica de emancipação, inclusive pelo trabalho não alienado, considerando os indivíduos e suas subjetividades.

Existe um nexo nos municípios que compõem a RMM, e este nexo se fundamenta nas necessidades particulares do território amazônico, que não é decisão de entes exógenos, mas de entes estabelecidos pelos grupos locais, pelos munícipes, pelos cidadãos, não alijados e não alienados de qualquer processo, conjuntamente com entes competentes. Isso se manifesta a partir dos movimentos, das lutas e dos instrumentos ou formas de trabalhos de solidariedade e cooperação como resistência ao modelo neoliberal excludente, logo a geopolítica do comum não se constitui como uma utopia, e ela pode se tornar uma práxis de fortalecimento das resistências imbricada às ações políticas territoriais de dissenso contra as múltiplas formas de alienação que se fazem manifestas no cotidiano vivido nos municípios que compõem a RMM.

Na virada do século XXI, mais precisamente no início do seu segundo decênio, a metropolização evidencia uma política do espaço, a geopolítica do comum pode ser pensada para a RMM, considerando que se sua vastidão territorial com todos os superlativos naturais e de contrariedade para a adequada gestão do território impede o desenvolvimento regional, a geopolítica do comum pode romper tais barreiras. E se isto é possível, torna-se imperativo encontrar os meandros dessa realidade, por isso se acredita na pertinência da abordagem, do tema, do recorte geopolítico territorial, a Região Metropolitana de Manaus.

\footnotetext{
15 Para Dardot e Laval (2017), a definição de comum pautada em um princípio da atividade política, não se pretende
} universal, trans-histórica e independente das condições temporais e geográficas. 


\section{REFERÊNCIAS}

[1] AMAZONAS. Lei Complementar no 52 de 30 de maio de 2007. Assembleia Legislativa do Estado do Amazonas. 30 de maio de 2007.

[2] AMAZONAS. Lei Complementar n 59/2007 de 27 de dezembro de 2007. Assembleia Legislativa do Estado do Amazonas. 27 de dezembro de 2007.

[3] AMAZONAS. Lei Promulgada no 64 de 30 de abril de 2009. Assembleia Legislativa do Estado do Amazonas. 30 de abril de 2009.

[4] BRASIL. Lei Complementar № 14 de 8 de junho de 1973. Presidência da República. Casa Civil, Subchefia de Assuntos Jurídicos. 8 de junho de 1973.

[5] BRASIL. Lei n. 13.089/2015. Institui o Estatuto da Metrópole, altera Lei n. 10.257 de 10 de julho de 2001, e dá outras providências. Brasília: DOU, 2015.

[6] CASTORIADIS, Cornelius. Socialismo ou barbárie. O conteúdo do socialismo. São Paulo: Brasiliense, 1983.

[7] CASTRO, Iná Elias de. Visibilidade da região e do regionalismo. A escala brasileira em questão. In: LAVINAS, Lena; CARLEIAL, Lana Maria da Frota; NABUCO, Maria Regina. (orgs). Integração, região e regionalismo. Rio de Janeiro: Bertrand, 1994, pp. 155-169.

[8] CASTRO, Iná Elias de; GOMES, Paulo César da Costa; CORRÊA, Roberto Lobato. Geografia: Conceitos e temas. 2.ed. Rio de Janeiro: Bertrand Brasil, 2000.

[9] DARDOT, Pierre, LAVAL, Christian. Propriedade, apropriação social e instituição do comum. In. Tempo Social, Revista de sociologia da USP, v. 27, n. 1, 2015, p. 261-273.

[10] DARDOT, Pierre; LAVAL, Christian. A nova razão do mundo: ensaio sobre a sociedade neoliberal. São Paulo: Boitempo, 2016.

[11] DARDOT, Pierre; LAVAL, Christian. Comum: ensaio sobre a revolução no século XXI. São Paulo: Boitempo, 2017.

[12] DARDOT, Pierre; LAVAL, Christian. A ideia do comum: teoria e história de um ideal. Youtube, 29 de setembro de 2017. Disponível em https://www.youtube.com/watch?v=AIQ2UbKs2pQ Acesso em: 05 maio 2018.

[13] FERREIRA, Álvaro; RUA, João; MATTOS. Regina C. de. O espaço e a metropolização. Cotidiano e ação. Rio de Janeiro: Consequência Editora, 2017.

[14] FERRIER, J. P. Pour une théorie (géographique) de la metropolisation. In. Cahier de la Métropolosation: enjeux et définition de de la métropolisations, 2001. Disponível em: http://www.metropolisation.org/cahiers_metropolisation/n_1. Acesso em 15 de setembro de 2018.

[15] GOMES, Paulo César da Costa. 0 conceito de região e sua discussão. In. CASTRO, Iná Elias de; GOMES, Paulo César da Costa; CORRÊA, Roberto Lobato. Geografia: Conceitos e temas. 2.ed. Rio de Janeiro: Bertrand Brasil, 2000.

[16] HAESBAERT, Rogério. Regionalização e territorialização na metrópole. In. FERREIRA, Álvaro; RUA, João; MATTOS. Regina C. de. O espaço e a metropolização. Cotidiano e ação. Rio de Janeiro: Consequência Editora, 2017.

[17] HARVEY, David. O neoliberalismo: história e implicações. São Paulo: Loyola, 2008.

[18] LENCIONI, Sandra. Região e Geografia. São Paulo: Edusp, 1999.

[19] LENCIONI, Sandra. Uma Nova Determinação do Urbano: o desenvolvimento do processo de metropolização do espaço. In: CARLOS, A. F. A. e LEMOS, A. I. G. (orgs.) Dilemas Urbanos: novas abordagens sobre a cidade. São Paulo: Contexto. 2003.

[20] LENCIONI, Sandra. Reconhecendo metrópoles: território e sociedade. In. SILVA, C. A. da; FREIRE, D. G.; OLIVEIRA, F. J. G de. Metrópole: governo, sociedade e território. Rio de Janeiro: DP\&A: Faperj, 2006.

[21] LENCIONI, Sandra. Metropolização do espaço: processos e dinâmicas. In FERREIRA, A. RUA, J. MARAFON, G. SILVA, A. C. P. da (orgs.). Metropolização do espaço: gestão territorial e relações urbano-rurais. Rio de Janeiro: Consequência, 2013. p. 17-34.

[22] LENCIONI, Sandra. Metrópole e sua lógica atual face ao regime de acumulação patrimonial. Mercator. V. 14, no 4, 2015 a.

[23] LENCIONI, Sandra. Metropolização do espaço e a constituição de megarregiões. In. FERREIRA, Álvaro; RUA, João; MATTOS, Regina Célia de (orgs.). Desafios da metropolização do Espaço. Rio de Janeiro: Consequência, 2015 b.

[24] LENCIONI, Sandra. Para além da urbanização metropolitana. Metropolização e regionalização pósmetropolitana. In. FERREIRA, Álvaro; RUA, João; MATTOS. Regina C. de (orgs.). 0 espaço e a metropolização. Cotidiano e ação. Rio de Janeiro: Consequência Editora, 2017 a. 
[25] LENCIONI, Sandra. Metrópole, Metropolização e Regionalização. Rio de Janeiro: Consequência, 2017 b.

[26] LENCIONI, Sandra. Referências analíticas para a discussão da metamorfose metropolitana. In. LENCIONI, Sandra; VIDAL-KOPPMANN, Sonia; HIDALGO, Rodrigo; PEREIRA, Paulo (orgs.). Transformações sócio-territoriais nas metrópoles de Buenos Aires, São Paulo e Santiago. São Paulo: FAU/USP, 2011.

[27] LEOPOLDO. Eudes. The space in transition: from urban-industrial economy to metropolitan-financial economy. In. MOORE CHERRY, Niamh; PIÑEIRA MARTIÑAN, Maria José (orgs.). Adressing Complex Urban Challenges: social, economic and cultural transformations in the city. Santiago de Compostela: IDEGA/USC, 2015.

[28] LEOPOLDO, Eudes. From urbanisation to metropolisation: new concepts and questions open to Urban Geography. In. MIERZEJEWSKA, Lidia; PARRYSEK, Jerzy. (orgs.). Cities in complex World: problems, challenges and prospects. Poznan: Bogucki Wydawnictwo Naukkowe, 2014.

[29] LEOPOLDO, Eudes. Financeirização imobiliária e metropolização regional: o Alphaville na implosão-explosão da metrópole. Tese de Doutorado. Faculdade de Filosofia, Letras e Ciências Humanas da Universidade de São Paulo. São Paulo, 2017.

[30] LIMA, Marcos Castro de. Quando o amanhã vem ontem: a institucionalização da Região Metropolitana de Manaus e a indução do processo de metropolização do espaço na Amazônia Ocidental. Tese de Doutorado. Faculdade de Filosofia, Letras e Ciências Humanas da Universidade de São Paulo. Departamento de Geografia, 2014.

[31] LIMA, Susane Patrícia Melo de; SOUSA, Isaque dos Santos. Reestruturação do espaço em Iranduba/AM e Manacapuru/AM: o processo de metropolização à luz de uma dinâmica recente. In. Anais do XV Simpósio Nacional de Geografia Urbana, 2017, Salvador: EDUFBA, 2017. p. 1-20. Disponível em: http://www.inscricoesxvsimpurb.ufba.br/

[32] MORAES, Reginaldo. Neoliberalismo: de onde vem, para onde vai?. São Paulo: SENAC, 2001.

[33] MOURA, Rosa. Morfologias de concentração no Brasil: o que se configura além da metropolização? In. Revista Paranaense de Desenvolvimento, Curitiba, n. 107, p. 77-92, jul/dez 2004.

[34] NOGUEIRA, Ricardo José B. Política e Território: a invenção de uma região metropolitana. In. Revista Somanlu, ano 11, n. 2, jul./dez. 2011, p. 175-198.

[35] OLIVEIRA, Francisco. Elegias para uma re(li)gião: Sudene, nordeste. Planejamento e conflito de classes 3. ed.Rio de Janeiro: Paz e Terra, 1981.

[36] PDIRMM. Plano Diretor Integrado da Região Metropolitana de Manaus (2010-2020). Governo do Estado do Amazonas. Secretaria da Região Metropolitana de Mananus. COnsórccio VETEC/VALENTE, 2010.

[37] RAFFESTIN, Claude. Por Uma Geografia do Poder. São Paulo: Ed. Ática, 1993.

[38] SANTOS, Tiago Veloso dos. Metrópole e Região na Amazônia: Concepções do planejamento e da gestão metropolitana em Belém, Manaus e São Luís. Tese (doutorado) - Universidade Federal do Pará, Núcleo de Altos Estudos Amazônicos, Pós-Graduação em Desenvolvimento Sustentável do Trópico Úmido, Belém, 2015.

[39] SANTOS, Tiago Veloso; SOUSA, Isaque dos Santos; LIMA, Susane Patrícia Melo de. Os grandes objetos urbanos: condição, meio e produto da metropolização regional na Amazônia Brasileira. In. Revista Acta Geográfica, Boa Vista, V. 12, no 29, Maio/Ago de 2018. p. 108-126. Disponível em https://revista.ufrr.br/actageo/article/view/4491.

[40] SOUSA, Isaque dos Santos. A ponte Rio Negro e a Região Metropolitana de Manaus: adequações no espaço urbano-regional à reprodução do capital. Tese de Doutorado. Faculdade de Filosofia, Letras e Ciências Humanas da Universidade de São Paulo. Departamento de Geografia, 2013.

[41] SOUZA, Marcelo José Lopes de. 0 território: sobre espaço e poder, autonomia e desenvolvimento. In. CASTRO, Iná Elias de; GOMES, Paulo César da Costa; CORRÊA, Roberto Lobato. Geografia: Conceitos e temas. 2.ed. Rio de Janeiro: Bertrand Brasil, 2000.

[42] SPOSITO, Eliseu Savério. Geografia e Filosofia: contribuição para o ensino do pensamento geográfico. São Paulo: UNESP, 2004.

[43] TRINDADE JR. Saint-Clair C. A cidade dispersa: os novos espaços de assentamento em Belém e a reestruturação metropolitana. Tese de Doutorado. Faculdade de Filosofia, Letras e Ciências Humanas da Universidade de São Paulo. Departamento de Geografia, 1998.

[44] TRINDADE JR. Saint-Clair C. A natureza da urbanização na Amazônia e sua expressão metropolitana. In. Geografares (Vitória), Vitória (ES), v. 1, n.1, p. 117-129, 2000.

[45] TRINDADE JR. Saint-Clair C. Grandes projetos, urbanização do território e metropolização na Amazônia. In. Terra Livre, São Paulo, v. 26, p. 177-194, 2006.

[46] TRINDADE JR. Saint-Clair C. Diferenciação territorial e urbanodiversidade: elementos para pensar uma agenda urbana em nível nacional. In. Cidades (Presidente Prudente), v. 7, p. 227-255, 2011. 


\section{Capítulo 7}

\section{Estado e Marxismo: Uma (re)leitura em tempos de "crise"}

\section{Márcia da Silva Pereira Castro \\ Izabella Patrícia Brito da Silva}

Resumo: 0 intento primordial do artigo é analisar a presença do Estado na sociabilidade capitalista a partir da interpretação marxista. Essa reflexão tem como foco o contexto contemporâneo que evoca a "crise" como principal causa dos retrocessos operacionalizados pelo Estado no que diz respeito aos vários aspectos sociais, econômicos e políticos. 0 percurso metodológico adotado para a análise foi a pesquisa bibliográfica que se ancora na tradição marxista. As contribuições de Marx e Engels, apesar de historicamente longínquas não se perderam no tempo, nem ficaram anacrônicas. Ao contrário, foram basilares para que outros pensadores contemporâneos ressignificassem seus fundamentos para entender a ampliação das atribuições do Estado em tempos de ideário neoliberal.

Palavras-chave: Estado; Capitalismo; Marxismo. 


\section{INTRODUÇÃO}

Estudar o Estado nos remete a analisar sobre a sociabilidade capitalista, afinal se trata de uma instituição que emerge em meio ao ocaso do feudalismo e a emersão do capitalismo, mas que ainda faz parte do nosso cotidiano, ou seja, do capitalismo contemporâneo.

Convencionalmente, seu papel de mediar os conflitos é sinônimo de Estado neutro; suas ações se respaldam no que está descrito em lei, ou seja, reflete a justiça, ao menos aparentemente. Mas é realmente possível existir essa neutralidade na sociabilidade capitalista, que é marcadamente dividida em classes sociais antagônicas?

Reflexões sobre essa interrogante são respondidas a partir de diferentes perspectivas. É salutar destacar que ideia de Marx e Engels sobre a atuação do Estado na sociedade capitalista é bastante incisiva, tanto que o termo "comitê executivo dos negócios da burguesia" se tornou emblemático e é recorrente. Mas não se encerrou por aí. Como veremos, coube a tradição marxista ampliar e reinterpretar o legado deixado por esses influentes pensadores.

Sob essa égide, nosso objetivo é analisar a atuação do Estado no modo de produção capitalista, especificamente, nos dias atuais em que a propagada "crise" tem se sobressaído nos discursos que permeiam diversas esferas, com destaque para a econômica e política. Para sua superação faz-se necessário que o Estado operacionalize verdadeiros retrocessos ("um mal necessário") ancorados em dispositivos ultraconservadores que propõem a superação da "crise", fato este que expressam os interesses de uma classe que busca a manutenção de uma ordem dominante posta.

Nesse percurso analítico, tem-se a necessidade de apontar as características que fundamentam o capitalismo, como ele se metamorfoseia, destacando a importância da (re)leitura da tradição marxista no debate sobre a sociabilidade capitalista e o Estado nesse cenário de "crise".

Nos utilizamos da pesquisa bibliográfica tomando como aporte teórico: Marx $(2018,2011)$, Engels (2018) e alguns relevantes pensadores que integram a tradição marxista como Gramsci (2001), Mandel (1986), Poulantzas (2000), entre outros que versam sobre o Estado e o capitalismo. Nossa análise ora exposta foi impulsionada pelas reflexões realizadas na disciplina Estado, Direitos e Políticas Sociais do Programa de pósgraduação em Serviço Social e Direitos Sociais (PPGSSDS/UERN).

Considerando que o estudo sobre um determinado tema é uma síntese provisória e histórica, sempre em construção, não temos a pretensão de fazer apontamentos de que uma ou outra abordagem foi superada pelos diferentes autores. Mas de dar visibilidade ao estudo do tema em comento buscando problematizálo no contexto de "crise" do século XXI.

\section{CAPITALISMO E ESTADO: UMA SINERGIA HISTÓRICA}

O capitalismo, enquanto modo de produção, emerge em meio ao fenecimento do feudalismo e emersão da sociedade burguesa que potencializa uma reestruturação no âmbito econômico, político e social e se aloca como um novo modo de produção hegemônico, primeiramente, na Europa e, posteriormente, se espraiando para outros continentes.

A burguesia vai se constituindo em uma classe social fundamental ao modo de produção capitalista que se desponta a partir da expansão do comércio ${ }^{16}$. Até então, a condição de subserviência da população aos senhores feudais que, não se eximiam de cobrar impostos, vai impulsionando as principais mudanças nesse cenário. Devido a essa condição, a burguesia, responsável pelo avanço econômico, além de se rebelar, parte dela, vai adquirindo terras e ampliando o domínio econômico para além do comércio que foi se desenvolvendo e absorvendo uma parcela significativa da população, dentre ela, os pequenos proprietários dos meios de produção.

\footnotetext{
16 Outros importantes fatos que contribuíram para a solidificação do capitalismo foram as Grandes Navegações que ajudavam na expansão do comércio para além da Europa. "A descoberta da América e a circunavegação da África criaram para a burguesia em ascensão um novo campo de ação [...] deram ao comércio, à navegação e à indústria um impulso, desconhecido até então, e, com ele, um rápido desenvolvimento ao elemento revolucionário na sociedade feudal em decomposição" (MARX; ENGELS, 2008, p. 9-10).
} 
Com isso, o movimento histórico que transforma os produtores em trabalhadores assalariados aparece, por um lado, como a libertação desses trabalhadores da servidão e da coação corporativa, e esse é único aspecto que existe para nossos historiadores burgueses. Por outro lado, no entanto, esses recém-libertados só se convertem em vendedores de si mesmos depois de lhes terem sido roubados todos os seus meios de produção, assim como todas as garantias de sua existência que as velhas instituições feudais lhes ofereciam. E a história dessa expropriação está gravada nos anais da humanidade com traços de sangue e fogo. (MARX, 2011, p. 962).

Enquanto uma parte dos trabalhadores existente nas cidades organizava-se em torno do artesanato e do comércio, os demais mantinham controle sobre as etapas do processo de produção. Ao passo que o comércio foi se expandindo, o capitalista passou a intermediar a produção, comprando o que era produzido pelos artesãos e vendendo por um preço maior, obtendo o lucro. Dessa forma, o trabalho foi saindo do controle do artesão e, concomitantemente, os trabalhadores passaram a realizar tarefas segmentadas, levando a uma especialização que foi acentuada com a Revolução Industrial (séculos XVIII e XIV), favorecendo a produção de bens em grandes quantidades. Essa nova forma de produção fez com que os trabalhadores não se reconhecessem naquilo que eles mesmos produziam, acarretando na falta de compreensão do processo de trabalho como um todo, em ações de caráter rotineiro e, muitas vezes, sem terem acesso ao produto final.

A relação capitalista pressupõe a separação entre os trabalhadores e a propriedade das condições da realização do trabalho. Tão logo a produção capitalista esteja de pé, ela não apenas conserva essa separação, mas a reproduz em escala cada vez maior. 0 processo que cria a relação capitalista não pode ser senão o processo de separação entre o trabalhador e a propriedade das condições de realização de seu trabalho, processo que, por um lado, transforma em capital os meios sociais de subsistência e de produção e, por outro, converte os produtores diretos em trabalhadores assalariados. (MARX, 2011, p. 961).

A Revolução Industrial, iniciada na Inglaterra, provocou uma intensificação da produção, visto que o trabalho passou a ser realizado também com o uso de máquinas. Logo, teve-se o aumento dos lucros dos proprietários dos meios de produção e na mesma proporção o aumento da exploração da força de trabalho.

Nessa estrutura as relações sociais de produção definem duas classes fundamentais: de um lado, os detentores dos meios de produção, que são os capitalistas; do outro, aqueles que dispõem apenas da sua força de trabalho para realizar as atividades, que é o proletariado. Assim, a estrutura e as lutas de classes nessa forma de sociedade constituíram um dos pontos de referência da teoria marxista: a contradição entre os que detêm os meios de produção e os que trabalham para produzir, compondo, assim, a essência da história social das lutas de classes (MARX; ENGELS, 2008).

Essa breve contextualização da conjuntura que marca o declínio do feudalismo e a ascensão do capitalismo é importante para que se tenha clareza de alguns elementos que fizeram parte do processo de transição, o qual trouxe alterações significativas ao modo de produção e que se espraiaram para além das fronteiras europeias, se irradiaram e transformaram profundamente a sociabilidade nos diferentes territórios através dos séculos até os dias atuais.

Como esse contexto posto, qual a sinergia entre capitalismo e Estado?

Apesar de o Estado não ter sido tema central das obras de Marx, sempre se fez presente, sendo interpretado por meio dos acontecimentos determinantes das estruturas produtivas da sociedade. Marx explicava que na sociedade humana primitiva não havia classes, nem tampouco Estado. As atividades e funções administrativas eram exercidas pelo conjunto dos membros da comunidade. Ao chegar em um determinado nível de desenvolvimento histórico essas atividades e funções passam a ser exercidas por grupos menores de pessoas que detinham força para impor as normas de organização para todo o grupo. Essa forma de organização composta por um núcleo de pessoas é que vai potencializar o desenvolvimento do Estado.

Conforme Engels (2018), o Estado, em sua gênese, constituiu-se a partir de um território sobre o qual exercia soberania através de uma força militar que se torna independente do conjunto do povo armado, 
ocupando o lugar de uma força coercitiva externa aos cidadãos ${ }^{17}$. E, finalmente, para exercer tais funções o Estado necessitava arrecadar os tributos e formar uma camada administrativa, a burocracia que também iria assumir a característica de uma camada externa e superior ao conjunto da população de um território.

0 Estado nasce, então, quando emergem as classes que, por conseguinte, apresentam interesses antagônicos. Esse seria, essencialmente, o motivo pelo qual surge a necessidade dessa instituição, tendo em vista, que a classe que detém os meios de produção carece de um meio para institucionalizar a manutenção da ordem, a qual lhe é favorecedora.

Como o Estado nasceu da necessidade de conter o antagonismo das classes, como, ao mesmo tempo, nasceu em meio ao conflito delas, é, por regra geral, o Estado da classe mais poderosa, da classe economicamente dominante, classe que, por intermédio dele, se converte também em classe politicamente dominante e adquire novos meios para a repressão e exploração da classe oprimida. (ENGELS, 2018, p. 62).

No Estado Absolutista, ou Antigo Regime, a contradição daqueles que viviam do ócio em detrimento dos que trabalhavam pela subsistência já era bem delimitada. Era a ilustração da contradição histórica do homem em sociedade, ou seja, "A história de toda a sociedade até hoje tem sido a história das lutas de classe" (MARX; ENGELS, 2008, p. 8).

Considerado por alguns estudiosos como um Estado de transição, o Estado Absolutista introduziu as primeiras medidas de "controle" mais sistemático sobre a classe trabalhadora, bem como sobre aqueles que se encontravam à margem do mercado de trabalho. Estatutos que os impediam de deslocar-se de um lugar para outro, que os proibia de reclames de salário, que os anteparava de qualquer tipo de associação (CASTRO, 2014) foram estratégias utilizadas para debelar a autonomia da classe mais empobrecida.

Nesse período, o Estado também foi responsável pela instituição da Lei dos Pobres que, passando por algumas alterações, perdurou por mais de dois séculos. Primeiramente implementado na Inglaterra, serviu de modelo para outros países que assumiram oficialmente o trato assistencialista e, ao mesmo tempo, repressor através do aparato estatal.

Ao longo dos séculos, com a consolidação do capitalismo, o Estado se reconfigura ampliando suas atribuições, sem abdicar do que lhe é inerente: atuar como principal agente mantenedor do sistema capitalista. Consequentemente, a sociabilidade polarizada entre duas classes fundamentais, burgueses e trabalhadores, tem o Estado como mediador de interesses antagônicos, mas sempre mantendo a sinergia com a classe burguesa/capitalista. Para Marx e Engels (2009), no processo de emancipação da propriedade privada em relação à comunidade, o Estado é a forma de organização dos burgueses garantirem a manutenção tanto de sua propriedade, quanto de seus interesses. Em outros termos, eles apontaram que a sociedade foi forjada pelo modo dominante de produção e que o Estado atua como um instrumento de classe que absorve os interesses particulares como se fossem de caráter universal.

Essa concepção de Estado como instrumento de dominação de uma classe sobre a outra estabelece uma relação entre as condições materiais de existência de uma determinada sociedade. Logo, o Estado é determinado pela estrutura social de modo a atender demandas específicas e garantindo que essa sociabilidade se perpetue.

Portanto, fica expresso que para Marx, o Estado não representava o bem coletivo e não superava as contradições existentes entre as classes, pois o modo de produção capitalista, visa validar a exploração da mais-valia e manter a lei da propriedade privada, contando com o amparo de diversos aparatos: jurídico, político, ideológico, coercitivo, para estabelecer e manter a ordem burguesa (im)posta.

Passados dois séculos após as provocações de Marx e Engels, o Estado através desse diversificado aparato tem absorvido problemas/atribuições crescentes frente as condições de aprofundamento da "crise" estrutural do sistema capitalista (MÉSZÁROS, 2015). E é centrado nesse dilema que a tradição marxista tem propiciado uma gama de produções acerca dessa sinergia entre Estado e capital.

\footnotetext{
17 Na Grécia antiga, por exemplo, a polícia foi formada de escravos, pois nenhum cidadão se dispunha a cumprir um papel tão odioso como o de ser uma tropa repressiva.
} 


\section{ESTADO EM TEMPOS DE “CRISE”: UMA (RE)LEITURA EM APORTES MARXISTAS}

As afirmações de Marx e Engels sobre o Estado são bastante incisivas. Certamente, porque são decorrentes das condições históricas em que estavam inseridos, na Europa do século XIX, onde a classe burguesa exercia sua dominação utilizando-se dos aparelhos repressivos que formam o Estado, levando-os a afirmar que: "O poder do Estado moderno não passa de um comitê que administra os negócios comuns da classe burguesa como um todo". (MARX; ENGELS, 2008, p. 12).

Mas as obras de Marx e Engels não ficaram restritas a uma época. Suas conjecturas sobre a sociabilidade capitalista foram se concretizando e sendo retomadas, analisadas, complementadas e questionadas por um vasto campo de produções. Prova disso, é o amplo arsenal que compõe a tradição marxista.

A "tradição marxista', diferenciada da "obra marxiana" (o que é de responsabilidade direta de Marx, as vezes em colaboração com Engels), deve ser vista como uma teoria rica e heterogênea, composta por variados autores e vertentes, debruçados sobre objetivos diversos em contextos variados. No entanto, se há diferenças entre as vertentes dessa tradição [...], há pelo menos um aspecto que lhe confere unidade interna: a perspectiva anticapitalista e de revolução. Isto é, trata-se de uma teoria social diversa, rica, heterogênea, que visa ao conhecimento crítico da estrutura e dinâmica capitalistas para sua superação. (MONTAÑO; DURIGUETTO, 2011, p. 33, grifos dos autores).

Na esteira da tradição marxista vários teóricos desenvolveram hipóteses, conjecturas e proposições acerca do sistema capitalista e, por conseguinte, sobre o Estado. São teorizações que, ao longo do último século, os autores foram agregando novas categorias para análise a partir de suas vivências, principalmente políticas em diferentes contextos.

Um primeiro estudioso que destacamos é Antônio Gramsci (1891-1937), cofundador do Partido Comunista italiano. Ele viveu em uma época em que a Itália estava dominada pelo fascismo, que propunha um Estado único, com apenas um partido, não dando margem para as ideias socialistas. Em virtude de sua militância nos partidos de esquerda, acabou sendo preso, período no qual escreveu os Cadernos do Cárcere ${ }^{18}$, uma de suas principais obras.

Para Gramsci, o Estado é formado por duas instâncias: a sociedade política, composta pelo governo, como aparelho repressivo do Estado; e, a sociedade civil que são as instituições (mídia, religiões, partidos políticos, entre outras).

Por enquanto, podem-se fixar dois grandes "planos" superestruturais: o que pode ser chamado de "sociedade civil" (isto é, o conjunto de organismos designados vulgarmente como "privados") e o da "sociedade política ou Estado", planos que correspondem, respectivamente, à função de hegemonia" que o grupo dominante exerce em toda a sociedade e àquela de "domínio direto" ou de comando, que se expressa no Estado e no governo jurídico". Estas funções são precisamente organizativas e conectivas. (GRAMSCI, 2001, p. 2021).

Assim, forma-se o Estado ampliado, com a função de consenso, de hegemonia, porém, "a natureza de classe do Estado e sua função de conservar os interesses particulares dessa classe por meio da repressão [...] são afirmações conservadas por Gramsci" (MONTAÑO; DURIGUETTO, 2011, p. 44).

Enquanto Marx propunha que a revolução seria por meio da luta armada, Gramsci entendia que seria por meio das instituições, dando ênfase aos partidos políticos. Dessa forma, a classe dominada deve contar com suas próprias instituições, para fazer frente a sociedade política no campo ideológico. Gramsci foi um percussor em pensar o Estado acrescido de funções e mediações.

Outro teórico é Ernest Mandel (1923-1995). Alemão, economista de formação possuindo uma vasta contribuição na produção intelectual e no ativismo político, chegando a ser líder da IV Internacional (1963). Ele escreveu suas obras em um contexto político em que parte da esquerda europeia alimentava fortes esperanças de uma revolução socialista e talvez, por isso, tenha sido um dos mais otimistas quanto a esta possibilidade.

\footnotetext{
18 Conjunto de 29 obras escrita por Antonio Gramsci no período em que esteve preso na Itália entre 1926 e 1937.
} 
Entre suas obras, vamos nos ancorar em 0 Capitalismo tardio $^{19}$, na qual mostra que a estabilidade vivenciada pelo capitalismo no pós-guerra, com base em um intenso crescimento econômico, não se estenderia por muito tempo. Essa fase

[...] caracteriza-se por dificuldades crescentes de valorização do capital (supercapitalização, superacumulação). [...] Outra característica do capitalismo tardio é a suscetibilidade crescente do sistema social e as explosivas crises econômicas e políticas que ameaçam diretamente todo modo de produção capitalista. (MANDEL, 1986, p. 340).

Nesse contexto de capitalismo tardio, o Estado estaria para além de comitê executivo da burguesia, sendo uma de suas funções "integrar as classes dominadas [...]" (MANDEL, 1986, p. 334), o que se daria por meio das políticas sociais. Esse fato demonstra uma fase em que o Estado reitera e aprofunda a questão do alastramento de suas atribuições.

Dentro da tradição marxista, essa mudança na função do Estado é uma ampliação do viés clássico. Não como forma de negação das formulações de Marx e Engels, mas em virtude dos contornos que o modo de produção capitalista foi se delineando que, por sequência, exigiram adequação por parte do Estado.

Outro importante estudioso, filósofo e sociólogo que integra a tradição marxista é grego Nicos Poulantzas (1936-1979). Sua intenção central foi analisar o caráter do Estado nas sociedades modernas, discorrendo sobre as estruturas do modo de produção capitalista (econômica, política e ideológica).

Poulantzas explica que para se analisar o Estado é necessário:

Estabelecer a relação do Estado com essas relações [de produção] significa desde já que as transformações do Estado em sua periodização histórica fundamental (estágios e fases do capitalismo [...]) levam a substanciais modificações das relações de produção e da divisão social do trabalho capitalista. (POULANTZAS, 2000, p. 125-126).

Ou seja, o Estado está imbricado no conjunto de determinantes, portanto, entendido como uma relação social que se funda nas lutas de classes e se condensa nas contradições da realidade concreta, aspecto fundamental para a compreensão de sua materialidade.

Parte de suas contribuições sobre esse tema, não concorda que o Estado seja uma entidade de direito exclusivo de uma classe. Assim, passa a evidenciar as contradições constitutivas que perpassam as relações de força, pois não possui um poder monolítico, uma vez que, “[...] em suma, representa, organiza o interesse político a longo prazo do bloco no poder, composto de várias frações de classe burguesa (pois a burguesia é dividida em frações de classe)". (POULANTZAS, 2000, p. 129, grifo do autor).

A abordagem relacional do Estado no capitalismo monopolista, permitiu a Poulantzas atualizar a forma de analisá-lo o que, em parte, demonstra a influência recebida de Gramsci no seu processo de amadurecimento intelectual, principalmente, no que concerne ao conceito de hegemonia. "Os aparelhos de Estado consagram e reproduzem a hegemonia ao estabelecer um jogo (variável) de compromissos provisórios entre o bloco no poder e determinadas classes dominadas". (POULANTZAS, 2000, p. 142). Destarte, reconhece a necessidade de concessões materiais estatais em favor das classes dominadas, com o intuito de proporcionar o consenso popular, elemento fulcral para a construção da hegemonia de uma classe.

A partir desses autores é percebível a capacidade que o capitalismo tem de se metamorfosear a cada processo de "crise" mais pontual, seja em diferentes territórios, seja em períodos históricos diversificados. Contudo, as crises cíclicas (MANDEL, 1986) vão se tornando, cada vez mais, frequentes dado estrangulamento do modo de produção. 0 alargamento das atribuições estatais, principalmente, através de políticas sociais, ao longo das décadas não foi suficiente para assegurar a estabilidade permanente da classe burguesa. Em outros termos, é a própria crise de legitimação do capitalismo (HARVEY, 2012) que o Estado e a burguesia intentam driblar.

Nesse constante "estado de crise", burguesia e Estado capitalista encontram no ideário neoliberal o respaldo favorável as suas convicções. Nessa sinergia de interesses da classe dominante, a classe 
trabalhadora composta por milhões de homens e mulheres padece com os rebatimentos e retrocessos no campo político, econômico e social. O capitalismo, a partir do seu processo de "crise" e recriação sob os auspícios do neoliberalismo, vem determinando, de maneira perversa, uma conjuntura na qual tudo que envolve a classe trabalhadora tem seu sentido subvertido, afetando diretamente a vida do ser social em todos os países, na medida em que limita suas possibilidades de desenvolvimento, desvalorizando suas potencialidades.

Na verdade, desde os anos 1990, em todos os continentes registraram-se crises financeiras, expressões localizadas da dinâmica necessariamente contraditória do sistema capitalista. E crises, não só as financeiras, fazem, também necessariamente, parte da dinâmica capitalista - não existe capitalismo sem crise. São próprias deste sistema as crises cíclicas que, desde a segunda década do século XIX, ele vem experimentando regularmente. E que, seja dito de passagem, não conduzem o capitalismo a seu fim: sem a intervenção de massas de milhões de homens e mulheres organizados e dirigida para a sua destruição, do capitalismo, mesmo em crise, deixado a si mesmo só resulta em mais capitalismo. (NETTO, 2012, 415).

Sob essas colocações é perceptível que o discurso da "crise", principalmente, do capital financeiro ${ }^{20}$, tem se espraiado nos diferentes Estados nacionais que se constituem os principais regulamentadores do processo de financeirização da economia.

Dadas as suas particularidades, as consequências para alguns países é um verdadeiro desmonte do que a classe trabalhadora minimamente conseguiu assegurar enquanto direito social. É uma "crise" que tem se intensificado desde os anos 1990 e, assim como outros países, o Brasil se alinha as perspectivas de superação adotando medidas de austeridade imposta pelos grandes organismos internacionais.

\section{0 ESTADO BRASILEIRO EM TEMPOS DE “CRISE”: ALGUMAS CONSIDERAÇÕES}

É válido ressaltar que um modo de produção que não se limita ao econômico, mas que adentra em todos os espaços da vida humana, favorecendo grandemente àqueles que se encontram na posição mais alta da pirâmide social, o que gera uma série de conflitos por parte da classe menos favorecida, por meio das lutas e reivindicações por direito a um trabalho digno e por todas as outras condições necessárias à sua sobrevivência.

No Brasil, entre tantas outras transformações, no que concerne ao mundo do trabalho, as consequências do capitalismo apontam para o aumento do desemprego estrutural ${ }^{21}$, crescimento dos subempregos, terceirização, privatização. E para agravar ainda mais as condições de sobrevivência da classe trabalhadora, tivemos recentemente a normatização do desmonte dos direitos trabalhistas por meio da Lei no 13.467/2017, que altera a Consolidação das Leis do Trabalho (CLT).

Por conseguinte, temos diante dos nossos olhos o aumento do fosso existente entre as classes, por meio da concentração de renda.

Os números apresentados pelo estudo A Distância Que Nos Une, da Oxfam, são chocantes: a riqueza dos seis maiores bilionários brasileiros equivale à dos 100 milhões mais pobres. Considerando o 0,1\% mais rico, sua renda em um mês é a mesma que um trabalhador com ganho de um salário mínimo receberia em 19 anos. (BOULOS, 2017, online).

\footnotetext{
${ }^{20}$ Ao nos reportarmos ao capital financeiro no contexto de "crise" a partir dos anos 1990, estamos considerando o processo de financeirização da economia de forma altamente especulativa, o que faz com que as crises se tornem sistêmicas à nível global (ver CHESNAIS, 2009). Caso exemplar, foi a crise registrada entre 2007-2008. Por ser um capital representado por títulos, obrigações, certificados e outros papéis negociáveis e rapidamente conversíveis em dinheiro, desconsidera ou minimiza a importância do capital advindo do processo produtivo.
}

21 "A taxa de desocupação do trimestre encerrado em março de 2018 chegou a 13,1\%" (IBGE, 2018), o que perfaz um total de 13,7 milhões de desempregados mas foi no governo de Fernando Henrique Cardoso (1995-2003) que se teve o ambiente propício à sua implementação e o ponto de partida se deu através do Plano Diretor da Reforma do Aparelho do Estado no início de seu governo. 
É um cenário que aponta uma alta concentração de renda deixando parte da população desprovida do acesso às necessidades básicas e tendo como principal orquestrador dessa situação o próprio Estado. São consequências de quase três décadas de aproximação com a perspectiva neoliberal. Desde o governo de Fernando Collor (1990-1992) o Estado tomou as primeiras medidas de incorporação do neoliberalismo, mas foi no governo de Fernando Henrique Cardoso (1995-2003) que se teve o ambiente propício à sua implementação e o ponto de partida se deu através do Plano Diretor da Reforma do Aparelho do Estado no início de seu governo.

Em 2003, com o início do governo de Lula da Silva (2003-2010), as políticas sociais estatais foram reconfiguradas e ampliadas, contudo devido aos embates e sobreposições das políticas econômicas, o Estado termina por fortalecer políticas minimalistas, focalizadas e pontuais. Essas mesmas características perpassam o governo da presidenta Dilma Rousseff (2011-2016) e devido o agravo da "crise" no contexto internacional, indicadores de recessão voltam a rondar o cotidiano da classe trabalhadora.

Com a chegada abrupta de Temer22 (2016-2018) ao comando do Governo Federal, o ideário neoliberal ganha novo fôlego e dispositivos formais que aprofundam a "crise" exatamente sob o discurso de que o Estado precisa ser reduzido. É nesse patamar que alguns dispositivos anteriormente insivibilizados ganham relevância no interior do aparato estatal e se materializam em Projetos de Leis, Emendas Constitucionais ${ }^{23}$, dentre outros. A intenção é de justificar as contrarreformas, pois na realidade se tratam de "[...] reformas orientadas para o mercado" (BEHRING; BOSCHETTI, 2007, p. 148) que vem sendo executadas, impelindo à opinião pública de que se trata de um fenômeno recente.

É perceptível como o Estado brasileiro tem conseguido manter a sua sinergia com os interesses capitalistas em detrimento dos frágeis direitos sociais da classe trabalhadora. Mesmo passando por constantes crises de legitimação (HARVEY, 2012), o capitalismo se reinventa a ciclicamente. E o que se percebe é que nessa metamorfose, manter apenas seu papel repressivo não daria ao Estado manter ad eternum a hegemonia capitalista, muito embora os aparelhos repressores exerçam um papel significativo da ordem capitalista (GRAMSCI, 2001).

O contexto histórico brasileiro das últimas décadas registra a importância que os aparelhos repressores tiveram em determinados períodos. Mas, paradoxalmente, foram nesses momentos em que as políticas sociais também se constituíram em verdadeiros "amálgamas" no processo de legitimação do sistema capitalista. Ou seja, mesmo que o Estado atenda primordialmente aos interesses de uma classe dominante burguesa, esse mesmo aparato é perpassado por uma correlação de forças que o faz ampliar o lastro das políticas sociais (POULANTZAS, 2000).

Em suma, os dispositivos legais que tem se instituído nos últimos anos no Brasil, se embasam em um discurso ideológico neoliberal de "crise", mas sempre vislumbrando, primordialmente, a proteção do capital financeiro. Vários estudos apontam o crescimento estratosférico dos lucros bancários ${ }^{24}$ que, juntamente às renúncias fiscais, perdão ou refinanciamento de dívidas colocam a classe trabalhadora como maiores lesados no processo nas medidas de austeridade propagadas pelos governos neoliberais.

Como resultante temos uma sociabilidade capitalista que se renova através de novas matérias-primas, fontes de recursos e mercados que enriquecem um pequeno quantitativo de pessoas concentradas no cume da pirâmide social, usurpando a possibilidade de condições mínimas de sobrevivência da grande maioria da classe trabalhadora dominada e explorada. Contudo, a autodestruição do planeta se alarga na mesma, ou até mais rápida, que a capacidade de se renovar. Nessa perspectiva é perceptível que "os limites absolutos do capital demonstram sua insustentabilidade em nosso tempo [...]" (MÉSZÁROS, 2015), e nesse cenário o Estado necessita ser "reinventado" ou incorporar atribuições que até o presente momento não se evocou.

22 O impeachment de Dilma Rousseff consistiu de uma questão processual que envolveu desrespeito à Lei Orçamentária e à Lei de Improbidade Administrativa por parte da presidenta, além de lançarem suspeitas de seu envolvimento em atos de corrupção na Petrobras.

23 PLP 257/2016, transformado em Lei Complementar 156/2016 (Lei de Responsabilidade Fiscal que aprofundam as restrições em relação aos servidores da União, dos estados, do DF e municípios); PL 867/2015 (Inclusão nas diretrizes e bases da Educação o Programa Escola sem partido); PEC 287/2016

(Reforma da Previdência e da Assistência Social); PEC 55 (congelamento do teto dos gastos públicos); PL 8939/2017 (entrega do setor privado o acesso à trilhões de barris de petróleo); Diminuição de vagas na graduação; Rechaço ao ensino crítico (ideológico).

24 Dentre outros estudos, ver síntese estatística no https://economatica.com/estudos/data/20180223a.pdf 


\section{CONSIDERAÇÕES FINAIS}

A pretensão do texto ora apresentado não foi esgotar as possibilidades sobre Estado na sociabilidade capitalista, mas, sim, fomentar debates que conduzam a discussões mais profundas, tomando a produção de Marx e a tradição dele decorrente como aporte teórico.

É consenso que a classe dominante precisa de uma instituição política que, aparentemente, esteja acima das classes, dos interesses particulares. Essa ideologia é uma ilusão que tem a finalidade de ofuscar a classe trabalhadora, fazendo-a acreditar que as situações de desigualdade são naturais, desvinculando-as das questões de classe.

Nessa direção, a reflexão formulada por Engels denota a correlação de forças entre o Estado e a iniciativa privada, o capital e o trabalho, aqueles que trabalham e os que verdadeiramente usufruem da riqueza produzida. Com efeito, não se trata de uma instituição que nos é exterior, como uma realidade metafísica, muito menos, uma instituição que tem como finalidade a justiça social.

Importa sublinhar que as ideias de Marx e de seus seguidores se coadunam. Afirmar, em sua época, que o Estado se configurava enquanto expressão da dominação de uma classe economicamente mais forte e, ainda, mostrar que a apropriação privada dos meios de produção acarretará, inevitavelmente, a luta de classes que, por sua vez, levará ao fim do Estado enquanto instrumento do capitalismo e ao triunfo do comunismo, foram ideias revolucionárias, fundamentadas em um admirável nível de consciência crítica. E eles buscavam difundir essas formulações para toda a classe trabalhadora, na intenção de impulsionar uma revolução, pois defendiam a socialização das riquezas produzidas coletivamente, para o equilíbrio da sociedade e o bem comum daqueles que produzem o desenvolvimento econômico.

Diante disso, a teoria marxiana responde apontando as contradições entre as classes como, de igual forma, afirmando a necessidade urgente de organização do proletariado e de transformação da realidade.

Considerando que não é pertinente atribuir um viés de completude as teorias de Marx, reiteramos que elas vão sendo aprofundadas, reinterpretadas, fazendo com que não se percam no tempo e se façam vivas por meio dos pensadores que lhes dão perenidade percorrendo as estradas históricas de produção e reprodução das relações sociais.

À guisa de conclusão, resta-nos a convicção de que o Estado, particularmente, o brasileiro, tem passado por diversas transformações, reflexo das próprias mutações que emergem do modo de produção capitalista que tem radicalizado, cada vez mais, o paradoxo da desigualdade social. Com efeito, entre as afirmações e complementaridades expostas, ficam as certezas de que o Estado é uma construção histórica e uma arena de disputas permeada pela correlação de forças e o jogo de interesses.

\section{REFERÊNCIAS}

[1] BEHRING, Elaine. BOSCHETTI, Ivanete. Política Social: fundamentos e história. 3a Ed. São Paulo: Cortez, 2007.

[2] BOULOS, Guilherme. 0 abismo brasileiro. 2017. Disponível em: <https://www.cartacapital.com.br/revista/974/o-abismo-brasileiro> Acesso em: 22 ago. 2018.

[3] CONTRIM, Gilberto. Filosofia. São Paulo: Saraiva, 2010, p. 264-284.

[4] CASTRO, Márcia da Silva Pereira. Política de assistência social no Brasil: uma análise a partir das tipologias de políticas públicas. 2009, 205f. Tese (Doutorado em Ciências Sociais)-Pós-Graduação em Ciências Sociais, Universidade Federal do Rio Grande do Norte, Natal, 2014.

[5] CHESNAIS, François. Mundialización: el capital financier en el comando. In: BORGIANNI, Elisabete; MONTAÑO, CARLOS (orgs.). Coyuntura actual, latino americana y mundial: tendencia y movimentos. São Paulo: Cortez, 2009. (Biblioteca latino-americana de servicio social. Serie antologias; v. 14).

[6] ENGELS, Friedrich. A Origem da Família, da Propriedade privada e do Estado. 1884. Disponível em: <https://www.marxists.org/portugues/marx/1884/origem/index.htm> Acesso em: 23 ago. 2018.

[7] GRAMSCI, Antônio. Cadernos do cárcere. 2. ed. v. 2. Rio de Janeiro: Civilização brasileira, 2001.

[8] IBGE. Desemprego volta a crescer no primeiro trimestre de 2018. 2018. Disponível em: <https://agenciadenoticias.ibge.gov.br/agencia-noticias/2012-agencia-denoticias/noticias/20995-desemprego-voltaa-crescer-no-primeiro-trimestre-de2018.html> Acesso em: 22 ago. 2018.

[9] MANDEL, Ernest. O capitalismo tardio. In: Os economistas. 2. ed. São Paulo: Nova Cultural, 1986, p. 333-350. 
[10] MARX, Karl. Crítica da Filosofia do Direito de Hegel. 1843. Disponível em: <https://www.marxists.org/portugues/marx/1844/critica/introducao.htm> Acesso em: 23 ago. 2018.

[11] MARX, Karl. O Capital. Crítica da economia política. Livro I. Volume I. 2ª Ed. São Paulo: Boitempo, 2011.

[12] MARX, Karl. ENGELS, Friedrich. Manifesto do Partido Comunista. São Paulo: Expressão Popular, 2008.

[13] MARX, Karl. A ideologia alemã. São Paulo: Expressão Popular, 2009.

[14] MÉSZÁROS, István. A montanha que devemos conquistar: reflexões acerca do Estado. (Trad. Maria Izabel Lagoa). 1.ed. São Paulo: Boitempo, 2015. (Mundo do Trabalho).

[15] MINAYO, Ma C. de Souza. O desafio do conhecimento: pesquisa qualitativa em saúde. 13. ed. São Paulo: Hucitec, 2013

[16] MONTAÑO, Carlos. DURIGUETTO, Ma Lúcia. Estado, classe e movimento social. 3. ed. São Paulo: Cortez, 2011.

[17] NETTO, J. Paulo. Crise do capital e consequências societárias. Serviço Social e Sociedade, São Paulo: Cortez, n. 111, 2012, p. 413-429.

[18] POULANTZAS, Nicos. O Estado, o poder, o socialismo. São Paulo: Paz e Terra, 2000, p. 125-163. 


\section{Capítulo 8}

Racismo: Sob a ótica social contemporânea no Brasil

\section{Boniek Pereira da Silva}

Monik Pereira da Silva

Antônio Vagner Almeida Olavo

Andres Juan Pablo Silva Sanchez

Antônio Henrique Queiroz Conceição

Resumo: Este estudo tem como objetivo apresentar o problema do racismo no Brasil na visão social. Como método utilizou-se o discurso histórico, sendo explicativo com fontes primárias e secundárias por meio de pesquisa bibliografia. Como resultado percebeu-se que o racismo é um processo vivo e que na prática social se concretiza e se evidencia de muitas formas, seja cultural, socioeconômica, política. Contudo, apesar da instrumentação jurídica, o fator determinante de discriminação está intrinsecamente enraizado no âmago cultural da sociedade.

Palavras-chave: Racismo. Social. Brasil. 


\section{INTRODUÇÃO}

Este capítulo discute o problema de racismo no Brasil sob a ótica social. É percebido que a temática levantada reflete um processo histórico em que a discriminação racial evidenciava o projeto de colonização de Portugal em nosso país, registrando que a cor da pele estabelecia a diferença de quem mandava e de quem obedecia.

Em que pese o desenvolvimento da sociedade ao conceito de raça em sua discriminação a de considerar que esse processo cultural permanece até hoje embora com invólucro disfarçado, mas que muito presente na realidade brasileira. É sob a análise desse cenário que o trabalho se desenvolve registrando o quanto o racismo é um processo vivo, dissimulando os preceitos legais, porém que na prática social é concreta e evidente.

O fator histórico cultural é um dos desencadeadores que agregado ao fator socioeconômico origina a manifestação racista em toda a sociedade. Assim, este estudo busca identificar e compreender a origem e a formação das manifestações racistas no Brasil.

Considerando que o racismo é um dos grandes problemas da sociedade brasileira, o presente trabalho visa contribuir para um melhor conhecimento desse processo social e econômico registrado historicamente sua evolução no cenário nacional, e assim poder contribuir e enriquecer o conhecimento acadêmico atual.

Este capítulo está estruturado em tem tópicos que são formados pela introdução, seguido pela metodologia. Os resultados desta pesquisa são apontados no tópico três. Por fim, as considerações finais.

\section{PROCEDIMENTOS METODOLÓGICOS}

O presente trabalho será desenvolvido utilizando o método histórico que consiste em investigar os acontecimentos, processos e instituições do passado para verificar sua influência na sociedade de hoje, para que se possa ser explicada a natureza do racismo no Brasil.

Quanto aos fins que se destina, a pesquisa será explicativa, uma vez que na concepção de Vergara (2015) embora apresente maior grau de complexidade não deixa de analisar, interpretar o problema levantado, trazendo à tona seus fatores determinantes e suas reais causas e efeitos.

Loureiro et al. (2012, p.33), afirmam que a metodologia

"é a definição dos procedimentos técnicos, das modalidades de atividades, dos métodos que serão utilizados. Vai depender da natureza do Trabalho, do tipo de pesquisa e dos objetivos propostos. É nesse tópico que o pesquisador registra os diversos momentos que a pesquisa irá percorrer e os instrumentos que serão utilizados em razão de sua natureza".

Desta forma, este estudo parte de uma abordagem qualitativa, com técnicas de pesquisa bibliográfica e documental. A primeira consiste em busca de livros e artigos que abordam sobre o tema. 0 segundo foi realizado por meio de documentos públicos como leis e decretos. Como critério de inclusão foram utilizados documentos e literatura que abordassem sobre o racismo.

A seguir iremos apresentar os resultados da pesquisa bibliográfica e documental realizado.

\section{RACISMO NO BRASIL}

Sanchez (2019), afirma que os autores André Carvalho e Margaret Costa na obra "Racismo", apresenta que todos os seres humanos têm antepassados comuns, mas alguns grupos, vivendo distantes de outros por muito tempo e submetidos à ambientes distintos, desenvolveram características físicas diferentes. Portanto, raças são apenas subdivisões de espécies. Talvez seja por isso que pessoas de certa raça estranhem a presença em seu meio de uma outra raça culminando com preconceito e posteriormente o racismo.

O racismo foi originado com próprio surgimento do homem, a intolerância é algo que desde sempre caracterizou a nossa espécie. Infere-se que o racismo à escala mundial teve início com a expansão marítima que tinha como seus principais percussores os portugueses.

Os portugueses, assim como toda a Europa, tinham seus valores morais, sociais, jurídicos e, por conseguinte, culturais, baseados nos dogmas da igreja católica que detinha extremo poder sobre os rumos 
das coisas terrenas, onde pregava que tudo existia e era da forma como se apresentava porque assim Deus o queria. Reis eram reis, vassalos eram vassalos, ricos eram ricos e pobres eram pobres porque assim Deus determinou que fosse (ARANHA; MARTINS, 2009).

Com isso, a igreja católica funcionava como uma espécie de intermediária entre o poder do Estado, personificado pelos reis, príncipes e outros nobres, e a grande massa servil que trabalhava para sustentar os luxos da nobreza. Essa nobreza detinha acesso às descobertas e suas possibilidades de enriquecimento, aos conhecimentos oriundos do intelecto humano como literatura, artes e demais seguimentos culturais, seguida de perto pelo clero e a burguesia em ascensão.

Tendo como cultura esse rígido sistema hierárquico-social medieval, à época do "descobrimento" do Brasil, consideravam os recém contatados "índios" como plebeus de almas perdidas, subumanos, ignóbeis necessitados da tutela da Igreja. Ou seja, estavam abaixo do nível social do plebeu comum europeu em todos os sentidos. Com esse preconceito estabelecido iniciaram a "colonização" do Brasil, assim, com a impressão preconceituosa de que o índio era preguiçoso, indolente, não confiável, traiçoeiro e menos inteligente.

Nota-se claramente que desde o início da "invenção" do Brasil uma predisposição racista muito comprometida com o status social, não muito diferente dos dias atuais.

Com a chegada dos portugueses ao Brasil houve a necessidade de arranjar mão de obra que ajudasse a construir uma nova colônia. Uma vez consolidado o Brasil como colônia portuguesa, uma nova civilização surgiu, um povo mestiço, mameluco ou, simplesmente, caboclo como queiram. E também mestiços eram os costumes dessa gente, o fato é que é essa a base da civilização brasileira. (GODOY et al., 2010).

Porém, outro fato mudaria consideravelmente a vida e os costumes no Brasil, já que os índios além de se negarem a trabalhar ainda se tornaram inimigos, que vez ou outra, entrava em conflito com o dominador português. Para isso os portugueses "exportaram" populações negras da África para o Brasil dando início ao flagelo da escravatura. Muitos povos seguiram o exemplo dos portugueses e a escravatura atingiu proporções à escala mundial (BENTES; ROLIM, 2008).

É nesse contexto histórico, que a base da civilização brasileira se edificou. É bem verdade, que nesse cenário houve os piores atos de crueldade humana: escravidão, lutas, perseguições, dizimações de vários povos.

Em meio a tudo isso, os costumes, os hábitos, a linguagem, as tradições de cada povo, tanto do livre quanto do escravo, do opressor ao oprimido se coadunaram, formando assim, a identidade social, mesmo com seus impressionantes contrastes.

Diante dessa combinação, mestiçagem, emergiu a sociedade hierarquizada. Daí a natural divisão, preconceito, discriminação, e desigualdade social latente. Portanto, se a história das civilizações é marcada pela luta de classes, inegavelmente na sociedade colonial, o processo não foi diferente, e hoje como resquícios de uma sociedade remota, constata-se os mesmos conflitos de interesses sociais, econômicos, políticos e culturais, resultantes da diferença racial. (LOPES, 2004).

A transferência temporária de sede do Reino Português trouxe grande desenvolvimento ao Brasil. Coube a corte ver in loco a situação da sua mais produtiva colônia. Porém, apesar do desenvolvimento quase nada nos trouxeram quanto ao pensamento social, principalmente quanto ao racismo que àquela época nem se falava, ainda viviam muito arraigados à cultura monárquica medieval. Mudanças mesmo só ocorreram a partir do momento em que, enriquecidos pelo comércio império neste momento histórico, passava por algumas mudanças no seu contexto social-político-econômico, como manifestações antiescravistas (abolicionista) (RIBEIRO, 2000).

A partir do final da década de 1860, o próprio governo imperial acabou reconhecendo que a extinção da escravatura no Brasil dependia apenas de condições políticas adequadas e da definição da forma de fazêla. Assim, em 28 de setembro de 1871, após 21 anos sem legislar sobre o assunto, aprovou a Lei Rio Branco (ou do Ventre Livre), declarando livre toda criança negra nascida a partir daquela data. Com isso cresceu a campanha abolicionista, que até então se restringia ao Parlamento e à imprensa. Admitia a inevitabilidade do fim da escravidão e até associava ao escravismo uma série de males da economia social - além de reconhecer a desumanidade da escravização de pessoas. Vemos que nem todos pensavam de forma torpe nesse período histórico.

As pressões sobre o Parlamento vinham aumentando desde 1884, quando se propôs a libertação dos escravos com mais de 60 anos. Mas somente em 1885 foi aprovada a Lei Saraiva - Cotegipe ou do 
Sexagenário, que emancipava o negro que alcançasse a idade de 65 anos. Tomado por rebeliões de escravos e manifestações populares nas ruas, agitado pela campanha de intelectuais e políticos abolicionistas, passava por um dos momentos mais tensos de sua história. Devido às fortes pressões internacionais (o Brasil foi o último país americano que mantinha a escravidão) o governo Imperial brasileiro, gradativamente, foi decretando leis abolicionistas: a Lei do Ventre livre, Lei dos Sexagenários e finalmente Lei Áurea.

E no dia 13 de maio de 1888, depois de dias de intensa agitação política, a princesa Isabel, filha de dom Pedro II, que substituía o pai no governo, assinou, com uma caneta de ouro (daí nome da lei), a Lei Áurea, abolindo a escravidão no país. A partir de então, cerca de 700 mil cativos tiveram legalizada a liberdade que na prática vinham conquistando naqueles anos de efervescência social.

0 texto simples e curto da lei, embora impedisse formas disfarçadas ou temporárias de escravidão, não se preocupou em integrar o negro e o índio (caboclos) à sociedade. 0 Brasil estava se transformando num país capitalista, mas os negros e os índios (caboclos) não foram preparados para essa mudança. (ALMEIDA, 2007).

Não houve por parte do governo nenhum empenho em cuidar da educação dos ex-cativos (99,5\% dos negros eram analfabetos) ou em lhes oferecer condições de sobrevivência, por exemplo, através da distribuição de terras (VILLA; FURTADO, 2017).

Pelo contrário, além de concorrerem com os trabalhadores imigrantes, os negros não tiveram acesso aos empregos mais qualificados e bem remunerados, geralmente ocupados por brancos. Tal situação, como vimos, passados mais de cem anos, mudou muito pouco.

Após a abolição da escravatura, acentuou-se no Brasil de forma espantosa a presença indesejável do negro liberto; escassos de recursos ficaram à deriva pelas ruas mendigando ou nas periferias das cidades e vilas embrionando o que hoje são as favelas (SOMBRA, 2018).

O Estado Brasileiro muda politicamente com a sua transformação em República federativa. Como se nota, tendo um passado tão conturbado, essa transformação ocorreu praticamente apenas nesse âmbito. A sociedade brasileira pouco mudaria, este primeiro período da História do Brasil, conhecido como república velha, é marcado pelo domínio político das elites agrárias mineiras, paulistas e cariocas. O Brasil firmou-se como um país exportador de café, e a indústria deu um significativo salto. Na área social, várias revoltas e problemas sociais aconteceram nos quatro cantos do território brasileiro, tendo o governo militar reprimindo duramente os defensores do regime monárquico.

Criaram uma nova Constituição, pois a anterior seguia os ideais da monarquia. Teve até um relativo avanço, mas nada significativo, pois as questões sociais mais elementares foram esquecidas. 0 que prevalecia, era o apoio e fortalecimento às elites agrárias, principalmente a mineira, a paulista e a carioca. Consequentemente a tradicional discriminação social, mãe do racismo brasileiro, seguia seu curso.

Quanto aos atuais dispositivos legais de combate ao racismo no Brasil, iniciando pela Constituição Federal/88, no seu artigo art. 5o, inciso XLI, que estabeleceu, em foro Constitucional, a prática do racismo como crime inafiançável e imprescritível, sujeito à pena de reclusão. Tão logo, as legislações posteriores se fundamentaram no artigo supracitado e pelo princípio da igualdade e da dignidade da pessoa humana.

O Brasil, assumindo sua mestiçagem populacional e também a existência de ideologias e pensamentos segregacionistas culturalmente estabelecidos, vem criando, a cada momento, novos mecanismos de combate ao racismo e a injustiça social. Algumas são facilmente aceitas como justas e coerentes outras causaram muita polêmica que até hoje gera discussão. Desta forma, Silva (2020) apresenta alguns dispositivos que estão presentes na Constituição Federal de 1988. Além de apresentar a lei 10.678 de 2003 da Secretaria Especial de Políticas de Promoção da Igualdade Racial, da Presidência da República.

Art. 3o Constituem objetivos fundamentais da República Federativa do Brasil:

IV - promover o bem de todos, sem preconceitos de origem, raça, sexo, cor, idade e quaisquer outras formas de discriminação.

Art. 4o A República Federativa do Brasil rege-se nas suas relações internacionais pelos seguintes princípios:

VIII - repúdio ao terrorismo e ao racismo; 
Art. 5o - Todos são iguais perante a lei, sem distinção de qualquer natureza, garantindo-se aos brasileiros e aos estrangeiros residentes no País a inviolabilidade do direito à vida, à liberdade, à igualdade, à segurança e à propriedade.

XLI - a lei punirá qualquer discriminação atentatória dos direitos e liberdades fundamentais;

XLII - a prática de racismo constitui crime inafiançável e imprescritível, sujeito à pena de reclusão, nos termos da lei;

A Constituição Federal faz uma rigorosa proibição de qualquer forma de discriminação contra os direitos fundamentais e as liberdades fundamentais (direito de ir e vir, liberdade de pensamento, de culto etc.). No inciso XLII foi rigorosa no sentido de proibir a prática da discriminação racial considerando um crime em que não se admite o pagamento de fiança para o acusado aguardar o julgamento em liberdade e poderá o responsável ser punido a qualquer momento.

A LEI No $10.678 / 03$, que cria a Secretaria Especial de Políticas de Promoção da Igualdade Racial, da Presidência da República, e dá outras providências.

Desta forma, o autor anterior apresenta a criação da Secretaria Especial de Políticas de Promoção da Igualdade Racial como uma política pública que visa formular, coordenar e articular ações que visam promover a igualdade racial (BRASIL, 2003). Assim, algumas ações como as cotas raciais nas universidades (BRASIL, 2012) e nos concursos públicos no âmbito federal (BRASIL, 2014).

O desenvolvimento da tecnologia de comunicações permitiu a criação da rede mundial de computadores e, com ela, as redes sociais, que se constituem de interfaces criadas virtualmente para conectar pessoas, grupos e empresas que partilham um objetivo comum, o de se comunicar, partilhar interesses e divulgar ideias, produtos e serviços. Toda rede social permite a criação de um perfil do usuário e de relações que este estabelece com quem deseja se comunicar. As redes sociais também permitem a criação de grupos específicos que compartilham um projeto de identidade, uma visão de mundo e, igualmente, dos preconceitos que estas pessoas têm em comum. Assim como no mundo real, no mundo virtual, as pessoas expõem a sua opinião sobre os mais diferentes assuntos da humanidade, incluindo temas como racismo e discriminação. (BARCELOS; PASSERINO; BEHAR, 2010).

Na esfera civil, a responsabilidade se define pelo dever de reparar os interesses privados, não importando tenha o ato praticado infringido disposição penal. A responsabilidade civil, de forma simples, pode ser definida como sendo a obrigação de reparar o dano causado a outrem. O dever de reparação tem fundamento na culpa ou no risco decorrente do ato ilícito do agente. O fundamento está na razão da obrigação de recompor o patrimônio diminuído com a lesão ao direito subjetivo.

0 réu pode ser civilmente obrigado à indenização do dano, e o fator gerador do prejuízo poderá não ser considerado uma conduta definida como crime. Isso quer dizer que pode um réu ser absolvido no juízo criminal, pela prática de um fato inicialmente considerado delituoso, e ser obrigado a indenizar à vítima, ao seu representante legal ou aos seus herdeiros, ou, ainda, reparar o dano provocado, perante o juízo cível de acordo com o Código Civil:

Art. 927 - Aquele que, por ato ilícito (arts. 186 e187), causar dano a outrem, fica obrigado a repará-lo. A verificação da culpa e a avaliação da responsabilidade regulam-se pelo disposto neste Código, arts. 927 a 943 e 948 a 954 (BRASIL, 2002).

Para o direito penal brasileiro (BRASIL, 1940) comentado por Mirabete (2019), a prática da discriminação e do preconceito por raça, etnia, cor, religião ou procedência nacional consiste em um delito previsto no Código Penal, in verbis:

Art. 140. Injuriar alguém, ofendendo-lhe a dignidade ou o decoro:

Pena - detenção, de 1 (um) a 6 (seis) meses, ou multa. 
§ 3o Se a injúria consiste na utilização de elementos referentes a raça, cor, etnia, religião, origem ou a condição de pessoa idosa ou portadora de deficiência: (Redação dada pela Lei no 10.741, de 01.10.2003)

Lei № 7.716/89 - Define os crimes resultantes de preconceitos de raça ou de cor, sendo esta alterada pela Lei № 9. 459/97. Nos seguintes artigos:

Art. 1․ Serão punidos, na forma desta Lei, os crimes resultantes de discriminação ou preconceito de raça, cor, etnia, religião ou procedência nacional. (Redação dada ao artigo pela Lei no 9.459, de 13.05.1997).

Art. 20. Praticar, induzir ou incitar a discriminação ou preconceito de raça, cor, etnia, religião ou procedência nacional.

Pena: reclusão de um a três anos e multa.

§ 1‥ Fabricar, comercializar, distribuir ou veicular símbolos, emblemas, ornamentos, distintivos ou propaganda que utilizem a cruz suástica ou gamada, para fins de divulgação do nazismo.

Pena: reclusão de dois a cinco anos e multa.

§ 2․ Se qualquer dos crimes previstos no caput é cometido por intermédio dos meios de comunicação social ou publicação de qualquer natureza.

Pena: reclusão de dois a cinco anos e multa.

§ 3‥ No caso do parágrafo anterior, o juiz poderá determinar, ouvido o Ministério público ou a pedido deste, ainda antes do inquérito policial, sob pena de desobediência:

I - o recolhimento imediato ou a busca e apreensão dos exemplares do material respectivo;

II - a cessação das respectivas transmissões radiofônicas, televisivas, eletrônicas ou da publicação por qualquer meio; (Redação dada pela Lei no 12.735, de 2012) (Vigência)

III - a interdição das respectivas mensagens ou páginas de informação na rede mundial de computadores. (Incluído pela Lei no 12.288, de 2010) (Vigência)

§ 4oNa hipótese do $\S 2^{2}$, constitui efeito da condenação, após o trânsito em julgado da decisão, a destruição do material apreendido. (Incluído pela Lei no 9.459, de 15/05/97)

Todavia, vale observar, porém, que o racismo não será extinto com leis (GRECO, 2017). Antes das Leis existe a necessidade de uma mudança de consciência no seio de nossa sociedade. Entretanto é imprescindível que se criem políticas públicas que venham pelo menos amenizar essas diferenças sociais e tentar promover igualdade de oportunidades.

O problema do racismo é tão contraditório que já foi feita uma lei contra a discriminação. Se não houvesse racismo, não haveria necessidade de criar lei contra racismo. Todavia, esta lei existente não resolve o problema, apenas pune. 0 racismo distorcido continua à tona, disfarçado.

\section{CONSIDERAÇÕES FINAIS}

Muito tempo se passou para que esse processo nocivo fosse notado e reconhecido. Diante dos fatos, grupos antirracismo e defensores da igualdade de direitos manifestaram sua indignação exigindo uma solução do Estado. Isso mobilizou as autoridades científicas do país a debater, pesquisar, coibir e encontrar, se possível, uma solução viável.

Dentre tantas renovações constitucionais (foram sete ao todo) apenas a mais recente estabelece claramente uma postura oposta ao racismo, quando em seu artigo $3^{\circ}$, inciso IV, estabelece os objetivos 
fundamentais da República Federativa do Brasil. A Constituição Federal Brasileira 1988, em seu artigo $5^{\circ}$ assegura que todos são iguais perante a lei, sem distinção de qualquer natureza. Portanto visualizamos a supremacia isonômica que impõe a todos os seres humanos, a igualdade como um direito fundamental para que haja harmonia social.

Registre-se o quanto o racismo é um processo vivo e que na prática social se concretiza e se evidencia de muitas formas, seja cultural, socioeconômica, política. E para regular essas manifestações o Direito se utiliza de instrumentos legais coercitivos.

0 texto constitucional prevê e proíbe o preconceito decorrente de origem, cor e raça e condena discriminações com base nesses fatores, consubstancia, antes de tudo, um repúdio à barbárie de tipo nazista que vitimara milhares de pessoas, e consagra a condenação do apartheid, por parte de um povo mestiço com razoável contingente de negros e índios.

Embora seja apenas no discurso, muitas outras leis fundamentadas nestes princípios surgiram com o objetivo de combater o racismo e/ou diminuir a desigualdade social que, pelo que verificamos, se não é a principal causa, contribui e muito para a cultura racista em nosso país. Não obstante a isso, apesar da instrumentação jurídica, o fator determinante de discriminação está intrinsecamente enraizado no âmago cultural da sociedade. Evidentemente, pode-se constatar esta assertiva nos discursos e consequentemente nos atos, ações que se configuram e se desenvolvem ao longo da história e nos dias presentes, revelandose principalmente no aspecto social.

Com avanço das Tecnologias da Informação e Comunicação (TIC), principalmente com o acesso a internet, o racismo comumente evidenciado em redes sociais digitas. Desta forma, é necessário potencializar políticas públicas, criação de as delegacias voltadas para crimes digitais, leis, educação e de conscientização para combater o racismo em diferentes lócus da sociedade.

Como pesquisas futuras, indica-se: a) 0 racismo nas redes sociais; b) mecanismos de identificação e de denúncias de racismo nas redes sociais digitais; c) o racismo na escola e; d) o poder da mídia e o racismo;

\section{AGRADECIMENTOS}

A Deus, luz, caminho, verdade e vida.

\section{REFERÊNCIAS}

[1] ALMEIDA, Rita Heloisa de. O diretório dos índios: um projeto de "civilização no Brasil do século XVIII". Brasília: Editora Universidade de Brasília, 2007.

[2] ARANHA, Maria Lúcia de Arruda; MARTins, Maria Helena Pires. Temas de Filosofia. São Paulo: Moderna, 2009.

[3] BARCELOS, Gilmara Teixeira; PASSERINO, Liliana Maria; BEHAR, Patrícia Alejandra. Redes sociais e comunidades: definições, classificações e relações. CINTED-UFRGS, Novas Tecnologias na Educação, v. 8, n. 2, jul. 2010.

[4] BENTES, Dorinethe dos Santos; ROLIM, Amarildo Rodrigues. O Amazonas no Brasil e no Mundo, Vol.4. Amazonas: Ed. Mens'sana, 2008.

[5] BRASIL. Constituição da República Federativa do Brasil de 1988. 5 de outubro de 1988, Brasília, 1988.

[6] BRASIL. Decreto-lei no 2.848, de 7 de dezembro de 1940. Código Civil. Diário Oficial da União, Brasília, 2014.

[7] BRASIL. Lei n. 10.406, 10 de janeiro de 2002. Institui o Código Civil. Diário Oficial da União, Brasília, DF, 11 jan. 2002. Disponível em: <http://www.planalto.gov.br/ccivil_03/leis/2002/110406compilada.htm>. Acesso em: 22 fev. 2021.

[8] BRASIL. Lei oㅡ 12.711, de 29 de agosto de 2012. Dispõe sobre o ingresso nas universidades federais e nas instituições federais de ensino técnico de nível médio e dá outras providências. Diário Oficial da União, Brasília, 2012.

[9] BRASIL. Lei no 12.990, de 9 de junho de 2014. Reserva aos negros 20\% (vinte por cento) das vagas oferecidas nos concursos públicos para provimento de cargos efetivos e empregos públicos no âmbito da administração pública federal, das autarquias, das fundações públicas, das empresas públicas e das sociedades de economia mista controladas pela União. Diário Oficial da União, Brasília, 2014.

[10] BRASIL. Lei no 2.040, de 28 de setembro de 1871. Declara de condição livre os filhos de mulher escrava que nascerem desde a data desta lei, libertos os escravos da Nação e outros, e providencia sobre a criação e tratamento daqueles filhos menores e sobre a libertação anual de escravos... Casa Civil, 1871. 
[11] BRASIL. Lei no 3.270, de 28 de setembro de 1885. Regula a extincção gradual do elemento servil. Casa Civil, 1885.

[12] BRASIL. Lei № 3.353, de 13 de maio de 1888. Declara extinta a escravidão no Brasil. Casa Civil, 1988.

[13] BRASIL. Lei no 10.678, de 23 de maio de 2003. Cria a Secretaria Especial de Políticas de Promoção da Igualdade Racial, da Presidência da República, e dá outras providências. Diário oficial da União. Brasília, 2003.

[14] GODOY, LAURET et al. Escola Viva - Programa de Pesquisa e Apoio Escolar. 12ª ed. São Paulo: Meca, 2010.

[15] GRECO, Rogério. Código Penal: comentado. - 11. ed. - Niterói, RJ: Impetus, 2017.

[16] LOPES, Luiz Roberto. História da América Latina - 10ª ed. Porto Alegre: Mercado Aberto, 2004.

[17] LOUREIRO, Amílcar Bruno Soares et al. Guia para Elaboração e Apresentação de Trabalhos Científicos. Porto alegre: PUCRS, 2012.

[18] MIRABETE, Júlio Fabbrini; Fabbrini, Renato N. Código Penal Interpretado.10 10 Ed.

[19] RIBEIRO, Darcy. O povo brasileiro: A formação e o sentido do Brasil. São Paulo: Cia das Letras. 2ª ed. 2000.

[20] SANCHEZ, Cleber. Fundamentos da Cultura Brasileira. Manaus: Travessia, 2020.

[21] São Paulo: Atlas, 2019.

[22] SILVA, José Afonso da. Curso de Direito Constitucional Positivo. 43a ed. São Paulo: Malheiros Juspodivm, 2020.

[23] SOMBRA, Raimundo Nascimento Guedes; LIMA, Luis Antônio. Fundamentos de História do Amazonas, $12^{\mathrm{a}}$ ed. Manaus: Editora Novo Tempo, 2018.

[24] VERGARA, S. C. Métodos de pesquisa em administração. São Paulo: Atlas, 2015.

[25] VILlA, Marco Antônio; FURTADO; Joacir Pereira. História do Brasil - Da Independência aos Nossos Dias, Vol. 10. São Paulo: Editora Moderna, 2017. 


\section{Capítulo 9}

Possibilidade de concessão do salário-maternidade à parentalidade homoafetiva na gestação substitutiva

\section{Camila Fenalti Salla}

\section{Andrea Nárriman Cezne}

\section{Mariana Fenalti Salla}

Resumo: 0 presente trabalho tem por objetivo analisar se há fundamento jurídico para concessão de salário-materniadade a casais homoafetivos do gênero masculino que tenham tido um filho por meio de barriga solidária, identificando quais os possíveis princípios norteadores para o suprimento desta lacuna. 0 método de abordagem utilizado foi o dedutivo; os métodos de procedimento, o histórico e o comparativo e as técnicas de pesquisa, a bibliográfica e a documental. Como resultado da pesquisa, identificou-se que são aplicáveis à situação analisada os princípios da dignidade da pessoa humana, da igualdade, da não discriminação e do melhor interesse da criança. Conclui-se, com base no estudo dos princípios mencionados, que existe fundamento jurídico para concessão de salário-maternidade a casais homoafetivos masculinos beneficiados por gestação de substituição.

Palavras-chave: Barriga solidária; Salário-maternidade; Uniões homoafetivas. 


\title{
1. INTRODUÇÃO
}

Muito embora tenha sido apenas nos últimos anos que os laços homoafetivos começaram a receber a devida atenção e amparo jurídico, desde os tempos mais remotos as relações homoafetivas se fazem presente na história da humanidade.

\begin{abstract}
As uniões homoafetivas sempre existiram em diversas sociedades e culturas, e hordienamente através de consideráveis lutas por seu espaço na sociedade ganham voz e buscam por seus direitos, desde os fundamentais assegurados na Constituição Brasileira, quais sejam, igualdade, liberdade, dignidade da pessoa humana, até os derivados da suas relações como parceiros, como, os direitos a união estável, aos direitos sucessórios e a possibilidade de adoção. (SILVA; TAVARES, 2015)
\end{abstract}

Foi nesse cenário, ao se despir de preconceitos, que a Suprema Corte brasileira, finalmente, posicionou-se acerca da temática, consolidando entendimento de união estável para casais do mesmo sexo. Foi deste veredito que as relações homoafetivas passaram a ser reconhecidas e retratadas nas decisões judicias proferidas pelos togados. É nessa lógica que Silva e Tavares (2015) afirmam ser de conhecimento já consolidado que o reconhecimento dos direitos à minoria, no presente caso, os homossexuais, assim como a tutela de seus direitos é tema bastante discutido na atualidade.

Nessa conjuntura de solidificação de posicionamento do Supremo Tribunal Federal passou-se a viabilizar o estabelecimento de união estável entre casais do mesmo sexo. Adriana Maluf (2010) salienta que o conceito de família vem sofrendo, no passar dos tempos, inúmeras transformações de caráter público e privado em face do interesse e do novo redimensionamento da sociedade. Isto posto, tornou-se possível, também, a adoção de filhos e a utilização de barriga solidária por parte desses casais.

No entanto, a Suprema Corte, ao consolidar entendimento, não tratou das questões previdenciárias que envolvem a realidade da barriga solidária, restando, dessa maneira, um espaço lacunoso na redação da lei. Não obstante, faz-se necessária a regulamentação previdenciária dessa matéria, porque, uma vez reconhecidos os direitos de família, por evidente abriu-se caminho para a necessidade de reconhecimento de questões previdenciárias, como o salário-maternidade para pais cujo filho é fruto de barriga solidária.

0 art. 71-A da Lei 8213/1991 foi alterado pela Lei 12.873/2013 e tornou possível salário-maternidade quando da adoção feita por homens, incluindo, assim, a possibilidade de pares homoafetivos masculinos gozarem de salário-maternidade. Entretanto, não foi previsto na lei o caso de filho fruto de barriga solidária, isto é, estabeleceu-se, assim, uma grande lacuna jurídica previdenciária. Lacuna jurídica que, consoante Mascaro (2013), é falta de norma para regular algum caso específico, in casu, saláriomaternidade para pais fruto de barriga solidária.

Diante dessa realidade, é de suma importância a análise da estrutura lacunosa, para que, dessa forma, possam ser vislumbradas formas a solucionar essa matéria de cunho social que importa a todos brasileiros. 0 Direito, enquanto sistema uno não pode vendar os olhos para realidades alarmantes como essa - havendo, assim, uma obrigação de suprir essa lacuna jurídica -, tendo em vista que na sociedade atual, com o reconhecimento dos direitos homoafetivos, avanço da biotecnologia e por vivermos em uma sociedade que se reconhece cada vez mais plural, essa situação se fará cada vez mais presente.

Nesse contexto, o presente trabalho tem por objetivo analisar se há fundamento jurídico para concessão de salário-materniadade a pares homoafetivos do gênero masculino que tenham tido um filho por meio de barriga solidária, identificando quais os possíveis princípios norteadores para o suprimento desta lacuna.

\section{DESENVOLVIMENTO}

A Constituição Federal de 1988 elencou dentre os direitos dos trabalhadores urbanos e rurais a "licença à gestante, sem prejuízo do emprego e do salário, com duração de cento e vinte dias". Ao lado disso, o art. 201 da Carta Magna previu que a previdência social atenderia à proteção da maternidade, especialmente à gestante. Nesse contexto, a Lei 8.213 de 1991 disciplinou o salário-maternidade, o qual é um benefício da previdência social que fora destinado, inicialmente, à mulher segurada por ocasião do parto. A duração do referido benefício é, em regra, de cento e vinte dias, podendo ter início entre vinte e oito dias antes do parto e a data de ocorrência deste. Quanto à sua natureza jurídica, Castro (2014) ressalta que não há que 
se confundir com a noção de salário stricto sensu, pois o salário-maternidade é benefício cujo ônus é integral da Previdência Social.

A princípio, o salário-maternidade era destinado somente às seguradas empregadas, trabalhadora avulsa e empregada doméstica. Consoante Dias e Macêdo (2012, p. 234) apontam, paulatinamente, a lei foi estendendo o benefício, passando a abranger a segurada especial e a segurada contribuinte individual e facultativa, de modo que atualmente "todas as seguradas da previdência social têm direito ao saláriomaternidade".

Ao longo de muitos anos o salário-maternidade foi concedido somente nas situações em que houvesse parto, ou seja, maternidade biológica. Somente no ano de 2002, o salário-maternidade passou a ser concedido às seguradas em caso de adoção ou de obtenção de guarda judicial para fins de adoção, porém com prazo de gozo do benefício diferenciado, vindo a se tornar igual no ano de 2012. Apesar dos grandes avanços, o benefício seguia sendo destinado exclusivamente às mulheres, o que impedia homens adotantes de desfrutarem desse período com seu filho(a).

Com intuito de sanar essa lacuna legal, foi aprovada a Lei 12.873 de 2013, a qual alterou o artigo 71-A da Lei 8.213/91, cujo caput passou a vigorar com a seguinte redação "Ao segurado ou segurada da Previdência Social que adotar ou obtiver guarda judicial para fins de adoção de criança é devido saláriomaternidade pelo período de 120 (cento e vinte) dias" (BRASIL, 1991). Com essa alteração, passaram também a ser beneficiários do salário-maternidade os homens solteiros ou casais homoafetivos masculinos que adotassem.

Além da adoção, outra opção que tem sido comum aos casais homoafetivos masculinos que desejam constituir família com filhos é a barriga solidária, também denominada de cessão temporária de útero, doação temporária de útero, ou ainda, gestação de substituição. Conforme afirma Maria Berenice Dias (2009)

Quando a ciência aprendeu a fazer a fertilização de um óvulo em laboratório e conseguiu implantá-lo no ventre feminino, ocasionou a maior revolução que o mundo teve a oportunidade de presenciar. Agora o sonho de ter filhos e de constituir família está ao alcance de qualquer um. Ninguém precisa ter par, manter relações sexuais, ser fértil para tornar-se pai ou mãe. Os métodos se sofisticaram e o Estado não teve outro jeito senão acompanhar esta evolução.(...) Também as famílias homoafetivas precisam ter acesso à filiação, ainda que, enquanto casal, não consigam procriar. Como não é possível negar o uso dos meios reprodutivos em face da orientação sexual de quem quer ter filhos, os homossexuais passaram a se socorrer da concepção medicamente assistida.

Nesse sentido, é relevante observar que no Brasil

é permitida a utilização da barriga solidária por um casal de homens homossexuais, pelo que não haverá a figura da mãe, mas sim de dois pais que elaboraram e executaram o projeto parental por meio de uma terceira pessoa, tendo esta última se oferecido voluntariamente para gestar em seu ventre o almejado filho. (MASSARO, 2014).

Paulo Lôbo (2011, p.223) ressalta que a legislação brasileira não acolheu expressamente a cessão do útero alheio, a prática é autorizada por Resolução do Conselho Federal de Medicina (Res. n. 1.957/10), com natureza de norma ética, a qual "admite a cessão temporária do útero, sem fins lucrativos, desde que a cedente seja parente colateral até o segundo grau da mãe genética.".

Na hipótese de geração de um filho(a) para um casal homoafetivo masculino mediante cessão temporária do útero, não há fato gerador do benefício de salário-maternidade para nenhum dos pais, vez que o parto não é realizado por eles e tampouco se trata de adoção. Surge, assim, uma relevante lacuna jurídica que se deve tentar dirimir mediante aplicação de princípios jurídicos.

\section{METODOLOGIA}

O presente trabalho realizou-se através do método de abordagem dedutivo, partindo-se de uma lei, in casu Lei 12.873 de 2013, e, em seguida, sob os olhares legislativos passou-se a refletir acerca da carência 
assistencial da lei a casais homafetivos, especificamente do sexo masculino e que tenham tido um filho por meio de barriga solidária. Os métodos de procedimento adotados foram o histórico, a partir de uma sucinta retrospectiva das recentes conquistas jurídicas dos homoafetivos, bem como se realizou uma breve restrospectiva também da Lei 8.213 de 1991 e das modificações trazidas pela Lei 12.873 de 2013; e o método comparativo, por meio de comparações entre o gênero feminino e masculino quanto aos direitos a serem assegurados.

As técnicas de pesquisa aplicadas foram a bibliográfica, por meio de análises de artigos científicos, assim como a documental, através do estudo da legislação brasileira, especialmente da Lei 12.873 de 2013.

\section{RESULTADOS E DISCUSSÕES}

A paternidade mediante gestação de substituição gerou para o sistema jurídico o que Bobbio (2011, p. 140) denominava lacuna jurídica "objetiva", as quais "são aquelas que dependem do desenvolvimento das relações sociais, das novas invenções, de todas aquelas causas que provocam um envelhecimento dos textos legislativos e que, portanto, são independentes da vontade do legislador." No caso, o legislador não logrou acompanhar o avanço da ciência e das relações sociais, não havendo previsão quanto à possibilidade de concessão de salário-maternidade aos pais de criança gerada mediante cessão temporária de útero.

Quando a lei for omissa, o legislador da Lei de Introdução às Normas do Direito Brasileiro (art. $4^{\circ}$ ) e do Código de Processo Civil (art. 126) determina que o juiz deverá decidir de acordo com a analogia, os costumes e os princípios gerais do Direito. No presente caso, para se tentar suprir a lacuna deixada pelo legislador, é preciso analisar os princípios do Direito e verificar se existe fundamento jurídico para a concessão de salário-materniadade a casais homoafetivos do gênero masculino que tenham tido um filho por meio de barriga solidária.

Iniciando-se a análise principiológica, merece destaque o princípio da dignidade da pessoa humana, o qual emerge como fundamento norteador da República na nova ordem constitucional. Consoante esse postulado, é defeso que qualquer pessoa seja tratada de forma não digna, discriminatória, desigual em razão de sua orientação sexual.

A partir dessa ótica, a dignidade humana, sustentáculo formativo dos princípios da liberdade e da igualdade, irradia-se nas relações jurídicas como barreira à discriminação por motivo de orientação sexual. Essa força irradiadora alça todos os rincões do ordenamento(...) (FACHIN, 2013, p. 69-70).

Destarte, a incidência do princípio atinge todos os ramos do Direito, incluindo o Direito Previdenciário, impedindo que o sistema jurídico regule de forma prejudicial ou desigual alguma situação em razão da orientação sexual dos envolvidos.

O princípio da dignidade da pessoa humana dá origem a diversos outros princípios, dentre eles, o princípio da igualdade, o qual, consoante a visão aristotélica, consiste em tratar igualmente os iguais e desigualmente os desiguais. Umbilicalmente ligado à igualdade está o princípio da não discriminação. Com relação a tais princípios Ragazzi e Bueno (2013, p.115) afirmam que

Por imposição constitucional, o legislador deve considerar, ao elaborar as normas que regem a sociedade, as diferenças, inclusive a diversidade de orientação sexual, sempre com o cuidado de não criar discriminação injusta e, se necessário, de lançar as justas. 0 aplicador do direito está sujeito aos mesmos ditames. Assim, se tomarmos por pressuposto a correta atuação estatal no resguardo da isonomia, a sociedade, por imposição legal ou judicial, está obrigada a respeitar as diferenças, em atendimento ao princípio da igualdade.

Dessa forma, o legislador, ao dar nova redação às disposições referentes ao salário-maternidade, deveria ter considerado as peculiaridades da hipótese de gestação de substituição em prol de casais homoafetivos. Não o tendo feito, o jurista tem o dever constitucional de suprir a omissão legal, de modo a evitar tratamento jurídico discriminatório.

Por fim, mas não menos importante, não se pode olvidar do princípio do melhor interesse da criança, que, tal qual os demais princípios supra mencionados, possui guarida constitucional. Consoante esse postulado, 
os interesses da criança devem ficar em posição de prioridade, com a proteção integral de seus direitos fundamentais.

Nesse contexto, relevante destacar que a função primordial do salário-maternidade é assegurar a convivência da criança com seu genitor (seja ele sua mãe biológica ou outrem), permitindo o sadio desenvolvimento psicossocial e o surgimento de laços afetivos. Tanto foi esse o escopo do legislador que há a previsão de que, falecendo a(o) segurada(o) que fazia jus ao recebimento do salário-maternidade, o benefício deve ser pago, por todo o período restante, ao cônjuge ou companheiro sobrevivente, exceto no caso do falecimento ou abandono do filho, hipótese em que o benefício perde sua razão de ser (art. 71-B, Lei 8.213/91).

Destarte, "A licença maternidade não é um direito que pertence só a mãe, mas a família como um todo. É de interesse social que os pais tenham um período mínimo e ininterrupto de convivência. Para que possam, da melhor maneira, criar a sua prole." (ANDRADE; CUSTÓDIO, 2014, p. 219). Nesse aspecto, Maria Berenice Dias (2015) afirma ser imperioso concluir pela existência de um direito fundamental à convivência familar, vez que "além de proteger a família - pois faz 20 vezes referência a ela - a Constituição garante a crianças e adolescentes, com absoluta prioridade, o direito à convivência familiar.".

Dessa forma, havendo conflito jurídico quanto à (im)possibilidade de concessão de salário-maternidade a casal homoafetivo, deve-se elevar o direito da criança à formação integral e à convivência com seus pais, garantindo-se sempre o melhor interesse dela.

\section{CONCLUSÕES}

A atual disciplina legal do salário-maternidade autoriza sua concessão a toda segurada mulher que tenha se tornado mãe, seja mediante gestação, seja mediante adoção. Recente alteração legislativa possibilitou também a concessão de salário-maternidade a segurados homens que tenham se tornado pais mediante adoção. Apesar dos avanços, resta existindo lacuna legal, vez que, na hipótese de um casal homoafetivo masculino tornar-se pai mediante cessão temporária de útero, não haveria fato gerador para concessão do salário-maternidade.

Por meio da pesquisa realizada, conclui-se que existe consistente fundamento jurídico para concessão de salário-maternidade a casais homoafetivos masculinos beneficiados por gestação de substituição, o qual se ancora em relevantes princípios constitucionais. Identificaram-se como princípios norteadores para o suprimento dessa lacuna os princípios da dignidade da pessoa humana, da igualdade, da não discriminação e do melhor interesse da criança.

Assim, o Direito não pode furtar-se às mudanças sociais, devendo o jurista enxergar o Direito como um sistema uno e aplicar os princípios jurídicos visando assegurar, acima de tudo, a dignidade da pessoa humana.

\section{REFERÊNCIAS}

[1] ANDRADE, Aline Duarte; CUSTÓDIO, Maraluce Maria. LICENÇA MATERNIDADE PARA CASAIS HOMOAFETIVOS: A concessão do direito a licença maternidade para casais homo afetivos. Letras Jurídicas, Belo Horizonte, n. 2, 2014. Disponível em: <http://npa.newtonpaiva.br/letrasjuridicas/wp-content/uploads/2014/09/LJ0236.pdf>. Acesso em: 01 jul. 2015.

[2] BOBBIO, Norberto. Teoria do Ordenamento Jurídico. São Paulo: EDIPRO, 2011.

[3] BRASIL. Constituição (1988). Constituição da República Federativa do Brasil: texto constitucional promulgado em 5 de outubro de 1988, com as alterações adotadas pelas Emendas Constitucionais no 1/1992 a 70/2012, pelo Decreto Legislativo no 186/2008 e pelas Emendas Constitucionais de Revisão no 1 a 6/1994. 36. ed. Brasília: Câmara dos Deputados, Edições Câmara, 2012.

[4] BRASIL. Decreto-Lei n. 4.657, de 4 de setembro de 1942. Lei de Introdução às normas do Direito Brasileiro. Diário Oficial [da] República Federativa do Brasil, Rio de Janeiro, 9 set. 1942. Disponível em: < http://www.planalto.gov.br/ccivil_03/

[5] decreto-lei/Del4657compilado.htm>. Acesso em: 05 jul. 2015.

[6] BRASIL. Lei n. 5.869, de 11 de janeiro de 1973. Institui o Código de Processo Civil.. Diário Oficial [da] República Federativa do Brasil, Brasília, DF, 17 jan. 1973. Disponível em: < http://www.planalto.gov.br/ccivil_03/leis/L5869.htm>. Acesso em: 06 jul. 2015 
[7] BRASIL. Lei n. 8.213, de 24 de julho de 1991. Dispõe sobre os Planos de Benefícios da Previdência Social e dá outras providências. Diário Oficial [da] República Federativa do Brasil, Brasília, DF, 25 jul. 1991. Disponível em: <http://www.planalto.gov.br/ccivil_03/leis/l8213cons.htm>. Acesso em: 07 jul. 2015

[8] CASTRO, Carlos Alberto Pereira; LAZZARI, João Batista. Manual de Direito Previdenciário. Rio de Janeiro: Forense, 2014

[9] DIAS, Eduardo Rocha; MACÊDO, José Leandro Monteiro de. Curso de Direito Previdenciário.São Paulo: Método, 2012.

[10] DIAS, Maria Berenice. Filiação homoparental e a reprodução assistida. Disponível em:<http://www.mariaberenice.com.br/uploads/15_-_filia\%E7\%E3o_

homoparental_e_reprodu\%E7\%E3o_assistida.pdf> Acesso em 07 jul. 2015.

[11] DIAS, Maria Berenice. Milagre da ciência. Âmbito Jurídico, Rio Grande, XII, n. 65, jun 2009. Disponível em: <http://ambito-juridico.com.br/site/index.php/\%09http:/www.cnj.jus.br/sistemas/600-presidencia/19112cadicor?n_link=revista_artigos_leitura\&artigo_id=6286\&revista_caderno=11>. Acesso em 04 jul. 2015.

[12] FACHIN, Melina Girardi. 0 direito homoafetivo à luz dos princípios constitucionais: a policromia da fotografia da família contemporânea na moldura constitucional. In: FERRAZ, Carolina Valença [et al] (Org.). Manual do direito homoafetivo. São Paulo: Saraiva, 2013.

[13] LÔBO, Paulo. Direito Civil: famílias. São Paulo: Saraiva, 2011

[14] MALUF, Adriana Caldas do Rego Freitas Dabus. Novas modalidades de família na pós-modernidade. 2010. Tese (Doutorado em Direito Civil) - Faculdade de Direito, Universidade de São Paulo, São Paulo, 2010. Disponível em: <http://www.teses.usp.br/teses/disponiveis/2/2131/tde-31012011-154418/>. Acesso em: 16 jul. 2015.

[15] MASCARO, Alysson Leandro. Introdução ao Estudo do Direito. São Paulo: Atlas S.A., 2013.

[16] MASSARO, Ana Carolina Pedrosa. A FILIAÇÃo EM FACE DA GESTAÇÃo POR SUBSTITUIÇÃO. O QUE DEFINE A PARENTALIDADE QUANDO OCORRE A INSEMINAÇÃO HETERÓLOGA? Revista do Instituto do Direito Brasileiro, Lisboa, n. 6, 2014. Disponível em: <http://www.idb-fdul.com/modo1_cat.php?sid=52\&ssid=118\&cid=57>. Acesso em: 05 jul. 2015.

[17] RAGAZZI, José Luiz; BUENO, Sérgio Luiz José. Homoafetividade e o direito à igualdade, à liberdade, à não discriminação e o respeito à diferença. In: FERRAZ, Carolina Valença [et al] (Org.). Manual do direito homoafetivo. São Paulo: Saraiva, 2013.

[18] SILVA, Ana Paula Rocha e. TAVARES, Maria Terezinha. Adoção por homossexuais no Brasil. Disponível em <http://www.seer.ufu.br/index.php/horizontecientifico/article/viewFile/3832/2837> Acesso em: 07 jul. 2015. 


\section{Capítulo 10}

Os Conceitos de Discurso e Ação em Arendt para justificar vivências de criação na área da Assistência Social

\section{Zenilda Batista Bruginski}

Resumo: Aqui se apresenta a reflexão teórica para empoderamento das pessoas nos espaços da assistência social a ser realizada pela não separação entre o discurso e a ação, baseada nos conceitos de Hannah Arendt. Para isso propiciando um espaço nas atividades, em que o ser humano possa se colocar integralmente tanto concebendo como agindo em vivências criativas daquilo que vai fazer, um espaço em que não há um repassador do que pode ou não ser feito, mas de liberdade, para que o ser em si não esteja separado de sua produção individual e coletiva.

Palavras-chave: discurso, ação, empoderamento. 


\section{INTRODUÇÃO}

Na assistência social comumente se veem os profissionais absorvidos por tantas atividades que normalmente a perseguição de uma linha teórica mais crítica na ação fica impossibilitada de se realizar. Aqui se trata de abrir caminhos para essa ação mais crítica, usando o pensamento de Hannah Arendt como reflexão para os espaços ocupados pelas diferentes formações acadêmicas na assistência, podendo elucidar sobre os efeitos da separação entre discurso e da ação na prática.

\section{DESENVOLVIMENTO}

O Livro "A Condição Humana" revela que o que distingue o homem, o que lhe é próprio, o que lhe é inerente em seu existir na era moderna é o trabalho.

Mais especificamente em seu capítulo $V$ aborda a ação. A ação humana é o que o revela. Mas junto da própria ação tem-se que encontrar o discurso. 0 discurso mostra a singularidade de cada um. Antes de o homem existir na terra já havia uma realidade. 0 homem com sua ação inicia novas realidades. Cada ser humano em sua condição própria e original ao nascer inicia o novo. Cada ser humano é um "novo". Esta é a sua grandeza, a sua diversidade que vai se expondo, desde sua tenra idade. Este ser vai se descobrindo também, vai adquirir linguagem, vai se expressar expondo o que é e através dos atos se mostrar ao mundo. É algo incomensurável saber até onde cada ser humano pode ir. 'Leonardo da Vinci' com suas mil facetas ativas, um ser multivariado, enorme, capaz, com tantas virtudes e qualidades inexplicáveis aos olhos da ciência foi um nascimento excepcional para a humanidade. Cada nascimento é algo/alguém especial, fora de série. Hannah Arendt fala dessa peculiaridade como a possível de transformações e mais transformações no contato com a terra e com os outros seres vivos. Embora haja grandes descobertas tecnológicas, nada vai superar o pensamento. Nenhuma máquina substituirá o homem. A ação que não acompanha o discurso, não é ação. É como se esta não existisse. Aqui se pode dizer que o homem desprovido do seu discurso na ação é uma reprodução mecânica. 0 homem pensa, age, esta (ação) desprovida daquele (discurso), não reafirma o homem como um nascimento. Enquanto houver nascimentos, a vida na terra é possível de se transformar.

Até aqui, vê-se a importância do discurso ligado ao ato. Quando não há discurso, compreensão, reflexão de cada ser em si no ato, parece que Arendt vai demonstrando que essa impossibilidade tem que ser revista.

Segue então suas reflexões, Arendt vai adiante.

Os homens agem, mas, não sozinhos, a ação está vinculada aos semelhantes. A ação pode ser de um ator, não de um autor. As pessoas se comunicam, há uma rede enorme de comunicação, as ações se dão entre as comunicações, discursos e ações andam juntos. Não há como a história da humanidade acontecer sem discurso e sem ação.

Se alguém tem alguma ideia ele vai comunicar essa ideia em discurso, segundo Arendt e virá a ação que é em conjunto com outros homens. A vida se move assim.

- A ideia de colocar a criação, a organização social em torno da criação como impulsionadoras de indivíduos usuários da assistência social pode ser colocada em atos por diversas vezes, em vivências institucionais, comunitárias. 0 discurso, no início, pode ser primário, porém ele se alarga para concepções teóricas, volta à realidade vivida pelas pessoas em tais ações, volta-se aos conceitos, pensa-se, redimensiona-se o apanhado, volta-se ao discurso, veem-se modificações sugestivas para ocorrer na prática entre os homens. Nem tudo são flores. Há sofrimento, sofrimento no pensar, sofrimento no agir, a reação das pessoas existe. Essa espiral, a "práxis" na construção do conhecimento, como dizia Marx, é eterna, contextual, ação e reação tudo comunga na vida pública. A ação em Arendt é complexa, para sua compreensão se exige mergulhar no texto para entender como um conceito amplo, histórico, inacabado, englobando discurso e ação, humanidade, contexto e que por aí vai se deslindando em seu entendimento.

Quando Arendt diz "A pluralidade humana, condição básica da ação e do discurso, tem duplo aspecto de igualdade e diferença" (ARENDT, 2001, p. 224), o termo "igual" se refere a que se os homens não fossem iguais, não se poderia compreender os antepassados, pois esta compreensão é real e se sabe dos feitos históricos e se entende o comportamento dos semelhantes porque cada um se identifica com os acontecimentos. E também se prevê o que fazer para as gerações futuras com base no que se conhece de si mesmo, porque se não fosse isto verdade, não se poderia planejar o que fazer para os novos nascimentos. Existe a alteridade, reconhecer o outro que no conjunto forma a pluralidade como segue o texto "Só o homem, porém, é capaz de se comunicar a si próprio e não apenas comunicar alguma coisa como sede, 
fome, afeto, hostilidade ou medo. No homem a alteridade, que ele tem em comum com tudo o que existe, e a distinção, que ele partilha com o que vive, tornam-se singularidades e a pluralidade é a paradoxal pluralidade dos seus singulares" (ARENDT, 2001 ,224). produto é concluído. Tudo já está pré-concebido. Foi a parte de leão exata do capitalismo industrial e que se estende até a nossa era. Essas condições de desligamento de discurso e ato são o terreno fértil para que muitos homens produzam alienadamente, não produziram o discurso, produzem o ato, a mão de obra; outros, não fazem as ações do discurso, mas toda preparatória discursal, contextual para que outros realizem o ato e não eles (concebedores intelectuais da ação). Separa-se aqui pensamento e ação que se estende por toda a teia de relações sociais. Para unificar novamente tornando o ser humano sujeito, há que haver discurso e ação por todos, em atividades propiciadoras dessa coragem, se não se quer reificar infinitamente a realidade atual.

Na produção humana concebida como ato a lei passa a atuar como reguladora de todo processo fabril. Porém, a imprevisibilidade acompanha a ação quanto a ela em si. Veja-se, "Contudo, as várias limitações e fronteiras que encontramos em qualquer corpo político possam oferecer uma certa proteção contra a tendência, inerente à ação, de violar todos os limites, são totalmente impotentes para lhes neutralizar a segunda característica relevante: a sua inerente imprevisibilidade" (ARENDT, 2001 , p. 241).

É na teia de relações, uma cidade é uma teia de relações, onde se dá a polis. A polis é ...l a organização da comunidade que resulta no agir e falar em conjunto[...]" (ARENDT, 2001, p. 248). A cidade-estado se situa entre pessoas que vivem juntas com tal propósito, não importa onde estejam" (ARENDT, 2001, p.248 249).

Nesta passagem a escritora alemã demonstra como se concebe a ação, o discurso e o poder:

0 poder só é efetivado enquanto a palavra e o acto não se divorciam, quando as palavras não são vazias e os actos náo são brutais, quando as palavras não são empregadas para velar intenções mas para revelar realidades, e os actos não são usados para violar ou destruir, mas para criar relações e novas realidades (ARENDT, 2001, p. 250).

Arendt (2001, p. 254), cita ainda, que as artes e ofícios também podem florescer em épocas de tirania. Talvez este endurecimento do planejamento da comunicar alguma coisa como sede, fome, afeto, hostilidade ou medo. No homem a alteridade, que ele tem em comum com tudo o que existe, e a distinção, que ele partilha com o que vive, tornam-se singularidades e a pluralidade é a paradoxal pluralidade dos seus singulares" (ARENDT, , 224).

0 que faz o homem distinto das coisas a mais que existem no planeta é a ação do discurso, como nos diz Arendt (2001, p. 224) a ação e o discurso são os modos pelos quais os seres humanos se manifestam uns com os outros, não como meros objetos físicos....]"

Outros aportes da autora vem ao longo do seu discurso apontando como a questão dos nascimentos por serem recém-chegados e iniciadores em virtude de terem nascido" (ARENDT, 2001, p. 226). E outros: à mediação de atos e palavras "Damos a esta realidade o nome de 'teia' de relações humanas" (ARENDT, 2001 , p. 232). À questão de que somos autores e produtores, Arendt rebate que somos agentes, muito interessante esta passagem "[...l ninguém é autor ou criador da história da sua própria vida. Por outras palavras, as histórias, resultado da ação e do discurso, revelam um agente, mas esse agente não é o autor nem produtor" (ARENDT, 2001, p. 233). Vive-se porque alguém pôs um ser humano no mundo e este ser humano se torna sujeito, mas não autor da sua vinda. 0 importante aqui é tornar-se sujeito. 0 resultado é ex post facto da ação e do discurso" (ARENDT, 2001, p. 235). Aqui se menciona o fato de ser mais depois da ação e do discurso, porque procurando se entender a autora em questão, a criação individual e social possibilita esse homem/mulher que não é autor nem produtor, ser agente, poder ser sujeito, aquele que domina o discurso e a ação, não como no modo fabril como se verá a seguir.

"Ao contrário da fabricação, a ação não é possível no isolamento. Estar isolado é estar privado da capacidade de agir" (ARENDT, 2001, p. 237). Por isso a criação coletiva nos remete à teia e esta ao ato vivo do discurso que faz parte do fluxo da vida. A defesa deste pressuposto é que relaciona a Arendt o tema do empoderamento pessoal e coletivo. Aqui o discurso e a ação devem estar juntos.

No mundo fabril a atividade em si é isolada, embora se dê num conjunto, num aglomerado de pessoas. Porém, se estas pessoas não conversarem o dia todo, o assistência social, vindo tudo concebido e pronto, impondo atos e limites no discurso e ação das pessoas possam ser redimidos pelas artes e ofícios. Mas, a centralidade que interessa é a ação e o discurso mesmo em tempos de tirania. Este é o ponto de inflexão.

Um estudo exploratório se faz necessário. 
Com o homo faber a sociedade logicamente para garantir a coesão social, coloca os produtos como bens supremos que garantem a vida, a vida como bem maior, contrapondo-se a ação e ao discurso como diz-se "coisa de quem não tem o que fazer". A passagem seguinte é ilustrativa, "De um modo geral, julgarão as actividades públicas pelo critério da utilidade, para fins supostamente mais nobres: no caso homo faber, tornar o mundo mais útil e belo, no caso do animal laborans, tornar a vida mais fácil e longa" (ARENDT, 2001, p.259) e, então denunciarão, por serem apolíticos, a ação e o discurso como ociosidade - intromissão ociosa ou conversa ociosa" (ARENDT, 2001, p.259) Como se não fossem o que faz a vida humana ser vida na terra.

Na seqüência do discurso sobre a ação, a autora se remete à visível percepção que mesmo publicamente as açöes devam ter um fim útil e belo. Parece que a utilidade que é a artífice do sistema capitalista que é toda a verdade possível e existente. Não há outras formas de vida que se possam imaginar. Inclusive com isto há a perpetuação do sistema econômico, como único possível na existência atual.

Há que os homens com seus nascimentos e suas vidas se libertem dessa via única e retomem talvez a única via redentora do propósito de nascer: a liberdade. Não como soberania, mas corno deixar de absorver o único pensamento vigente e dialogar sobre ele. A retomada do discurso e da ação como bens públicos. Este trecho remete a uma sutileza, "A suposição de que a identidade de uma pessoa transcende em grandeza e importância, tudo que ela possa fazer ou produzir é um elemento indispensável da dignidade humana" (ARENDT, 2001, p. 263). Veja-se bem, o que faz é produto, o que se é, é sujeito, pois,

O que salva os talentos verdadeiramente grandes é que os que arcam com esse ónus permanecem superiores ao que fizeram, pelo menos enquanto estiver viva a fonte da criatividade, pois a fonte, na verdade, emana de quem eles são e é portanto, exterior ao processo real de trabalho e ao mesmo tempo que é independente do que possam realizar. (ARENDT, 2001, p. 263).

A ação humana é dissecada e, portanto, feita em seus desdobramentos para se compreender, discurso e ação é o modus vivendi da humanidade. Filósofos dissecaram discurso e ação para justificar suas idéias. Veja-se,

A separação platónica entre o saber e o fazer permaneceu na base de todas as teorias do domínio que não se limitam a simples justificação de uma irredutível e irresponsável vontade de poder. A força de mera conceptuação e elucidação filosófica, a identificação platónica do conhecimento com governo e comando, e da açáo com obediência e execução, prevaleceu sobre todas as experiências e manifestações prévias da esfera pública e impôs-se como verdade autorizada à tradução do pensamento político, mesmo depois de esquecidas há muito tempo as raízes da experiência que serviria de base aos conceitos de Platão (ARENDT, 2001, p. 276).

O contraponto do pensamento acima coloca na ação a virtude dos homens, agir é preciso, mesmo sem a certeza dos seus resultados. Agir traz o novo e o novo se faz com discurso e ação. Pois,

[...] seja qual for o poder mental necessário para os desencadear, a capacidade humana responsável por esse poder mental é a única força capaz de realizar tais feitos - não é nenhuma capacidade 'teórica', não é contemplação nem razão, é a faculdade humana de agir, de iniciar processos novos e sem precedentes, cujo resultado é incerto e imprevisível [...] (ARENDT, 2001, p. 283).

E aqui vai a proposta "Se podemos conceber a natureza e a história como sistemas de processos é porque somos capazes de agir, de iniciar nossos próprios processos" (ARENDT, 2001, p. 283).

Quando se inicia um novo processo, um novo ciclo prova-se o nascimento. Nascer é existir, existir desprovido de discurso e ação é fabricação. Pensar, mundo das idéias e agir, faz parte da pluralidade humana, de ser no mundo. Cada um pode iniciar o seu processo de interferência no mundo em que nasceu. 
Quando se diz,

Enquanto a força do processo de fabricação é inteiramente absorvida e exaurida pelo produto final, a força do processo de ação nunca se esvai num único acto, mas, pelo contrário, pode aumentar à medida que se lhe multiplicam as conseqüências (ARENDT, 2001, p. 284-285).

Vê-se aqui a veracidade do parágrafo anterior.

Fechando aqui as reflexões sobre o texto de Hannah Arendt põe-se que, de todas as dimensões por ela abordadas e suas reflexões àcerca da vida humana e do que remete a criação como empoderamento de usuários da assistência social, o que se quer mencionar é que no decorrer do tema a ser trabalhado se vai utilizar a concepção contundente de discurso e ação na esfera humana, concebida pela autora para discorrer sobre a idéia e a prática de vivências com esse intuito.

\section{CONSIDERAÇÕES FINAIS}

E assim fecham-se as considerações acima com o discurso visionário de que,

Fluindo na direçäo da morte, a vida do homem arrastaria consigo, inevitavelmente, todas as coisas humanas para a ruína e a destruição, se não fosse a faculdade humana de interrompê-las e iniciar algo novo, faculdade inerente à acção como perene advertência de que os homens, embora devam morrer, não nascem para morrer, mas para começar (ARENDT, 2001, p. 299).

Por isso, é possível ter esperança.

Ação portanto, vê-se aqui, como discurso e ato, englobados e não separados como na produção fabril.

\section{BIBLIOGRAFIA}

[1] ARENDT, Hannah. A condição Humana. Trad. Roberto Raposo. Lisboa. Relógio D' Água Editores. 2001. 


\section{Capítulo 11}

\section{Elementos sociais, culturais e econômicos da adolescência no Espectro do Autismo}

\section{Amanda Pereira Risso Saad \\ Paulo Roberto Haidamus de Oliveira Bastos \\ Geisa Alessandra Cavalcante de Souza}

Resumo: Profundas transformações psicossociais ocorrem na adolescência, podendo ser experienciadas com conflitos pertinentes às mudanças corporais, emocionais e sociais, especialmente para população com Transtorno do Espectro do Autismo. Assim sendo, este estudo quantitativo teve como objetivo caracterizar elementos sociais, culturais e econômicos de adolescentes institucionalizados com Transtorno do Espectro do Autismo, no município de Campo Grande, Mato Grosso do Sul, a partir de dados primários, de coleta direta por formulário autoral, destacando peculiaridades que favoreçam o processo de inclusão social. Os resultados demonstraram comprometimentos relacionados à inclusão social, considerando que a escola apresentou dificuldades para absorver demandas que emergiram do processo da adolescência no espectro do autismo. Quanto à vulnerabilidade de elementos econômicos, os resultados não demonstraram relação direta com o acesso à educação, cultura, esporte e lazer. Houve destaque para o protagonismo das mães no cotidiano dos adolescentes, sugerindo a necessidade de abordagens profissionais integrativas entre família, escola e serviços em saúde, no contexto do exercício pleno de cidadania.

Palavras-chave: Adolescentes. Transtorno Autístico. Educação Especial. Inclusão Escolar 


\section{INTRODUÇÃO}

\subsection{TRANSFORMAÇÕES PSICOSSOCIAIS NA ADOLESCÊNCIA}

Inúmeros conceitos são utilizados para definir a adolescência e suas variações decorrem da região, época e cultura que se pretende abordá-la. Segundo a Organização Mundial de Saúde (OMS) este período é definido pela faixa etária de 10 a 19 anos e dentre as inúmeras transformações, destacam-se às mudanças corporais, emocionais e sociais.

As mudanças corporais referem-se ao período da puberdade, considerado como fase universal e inerente à espécie humana, com início na segunda década de vida e expressa-se por alterações no corpo, que estão mais propícias à reprodução. A adolescência pode apresentar diversidade de sentidos de acordo com a cultura vigente e está relacionada com transformações psicológicas e sociais, no período entre a infância e idade adulta (SANTOS; XAVIER; NUNES, 2009).

Em relação às transformações psicológicas, destaca-se o desenvolvimento da identidade do adolescente, quando há elaboração do autoconceito e de conceitos que os outros fazem dele, processo pelo qual é considerado um dos alicerces da personalidade, desenvolvido a partir da relação com o meio social (SPRINTHALL; COLLINS, 2003).

Renunciar aspectos do universo infantil é um dos principais elementos a serem superados na adolescência e deve ser apoiado pela família de maneira a estimular novas experiências pertinentes ao universo adolescente. No entanto, o equilíbrio necessário que facilita esta passagem da infância para adolescência requer condutas que permitam a independência, em um constante jogo de distanciamento e proximidade entre a família e o adolescente (KERNIER; CUPA, 2012).

Considerado eixo crítico das relações familiares de adolescentes, o estímulo da independência exige constante reflexão dos pais, em decorrência da necessidade de renúncias em determinadas áreas do desenvolvimento do adolescente, principalmente em relação aos aspectos em que consegue se posicionar com maturidade, intercalando com maior controle frente aos aspectos em que as decisões estão imaturas (SANTROCK, 2014).

A construção de identidade pessoal será amplamente influenciada por diferentes contextos do adolescente, nos quais o convívio com a família, escola, instituições e acesso a cultura, arte, lazer, esporte e novas tecnologias repercutirão em melhor adaptação do adolescente às diferentes demandas da vida em sociedade (PINO, 2005; PRATTA; SANTOS, 2007).

$\mathrm{O}$ acesso à preparação para mercado de trabalho representa importante aquisição de responsabilidades e ampliação do desenvolvimento psicossocial do adolescente, com características singulares para a construção de uma identidade adulta, ampliação de seu pensamento sobre o mundo e sobre as pessoas (MANFEZOLLI, 2004; PAPALIA; OLDS; FELDMAN, 2010; SANTOS; XAVIER; NUNES; 2009; TEDESCO et al., 2006; UNICEF, 2011).

\subsection{ADOLESCÊNCIA NO ESPECTRO DO AUTISMO}

As diferentes transformações inerentes ao desenvolvimento psicossocial da adolescência também estão presentes no contexto de pessoas com Transtorno do Espectro do Autismo (TEA), e os conflitos inerentes a esta fase, podem ser acentuados de acordo com o nível de comprometimento e acesso ao suporte individual e familiar.

As instituições que oferecem assistência a esta população representam importante mecanismo para ampliação do desenvolvimento integral de jovens e familiares, incluindo relacionamentos com seus pares de desenvolvimento (SCHMIDT; BOSA; 2007).

A partir da 5a edição do DSM, a definição de TEA caracteriza-se por comprometimentos qualitativos no desenvolvimento sociocomunicativo, comportamentos estereotipados e repertório restrito de interesses a atividades. Estes sintomas quando em conjunto limitam ou dificultam o cotidiano do indivíduo, de acordo com diferentes intensidades dentro do espectro (AMERICAN PSYCHIATRIC ASSOCIATION, 2013).

As demandas decorrentes do TEA exigem das famílias importante investimento de tempo e de recursos financeiros no cuidado diário, a fim de prover as necessidades do adolescente (BRASIL, 2013; COSSIO; PEREIRA; RODRIGUES, 2018). Dentre as principais dificuldades destes familiares, observa-se a recusa em desprender-se da identidade infantil, influenciando negativamente no desenvolvimento psicossocial da 
pessoa com TEA, considerando a privação de experiências inerente ao universo adolescente (KERNIER; CUPA, 2012; SPROVIERI; ASSUMPÇÃO JÚNIOR, 2001).

Neste sentido, famílias precisam ser apoiadas a partir de suportes sociais e programas de atenção aos pais e/ou responsáveis que priorizem a superação das fragilidades familiares frente a presença de um membro com TEA (COSSIO; PEREIRA; RODRIGUES, 2018; CURSINO; CURSINO; VIEIRA, 2016; DANTAS et al., 2019; FARO et al., 2019).

Além do tratamento individualizado ao adolescente e suporte às famílias, a inclusão da pessoa com TEA em atividades esportivas e de lazer proporciona ampliação das habilidades sociais, promoção de saúde e prevenção de incapacidades. 0 esporte utilizado no contexto das deficiências, além de constituir-se direito, favorece a autonomia e reabilitação psicossocial (BRASIL, 2015; PHEBO; ROBIM, 2012).

As novas tecnologias também são importantes aliadas para o ensino e ampliação de habilidades sociais de pessoas no espectro do autismo, considerando que os recursos visuais despertam o interesse e favorece o contato com os pares (BRASIL, 2013; PASSERINO; SANTAROSA, 2007).

Na esteira da ampliação das habilidades sociais e cognitivas, programas de incentivo e preparação para pessoas com deficiências atuarem no mercado de trabalho são considerados importantes mecanismos para reflexão do modelo hegemônico atual de independência e produtividade. Possibilitam fomento de novas sensibilidades sociais de inclusão social e construção da diversidade em ambiente corporativo, favorecendo a qualidade de vida do próprio sujeito com deficiência e seus companheiros de trabalho (AYDOS, 2016).

Neste sentido, o presente estudo caracterizou aspectos sociais, culturais e econômicos de adolescentes com TEA no município de Campo Grande, MS, com vistas às peculiaridades que favoreçam o processo de inclusão social.

\section{MÉTODO}

Este artigo é um recorte de dissertação de mestrado, desenvolvida em 2016, no Programa de PósGraduação em Saúde e Desenvolvimento na Região Centro-Oeste, ofertado pela Universidade Federal de Mato Grosso do Sul. Esta é uma pesquisa quantitativa que objetivou caracterizar elementos sociais, culturais e econômicos de adolescentes institucionalizados com TEA, a partir de dados primários, de coleta direta por formulário autoral, realizada no munícipio de Campo Grande, MS, destacando peculiaridades que favoreçam o processo de inclusão social.

A caracterização envolveu informações sobre:

- Sexo;

- Idade;

- Frequência escolar;

- Renda familiar;

- Número de dependentes.

Para análise estatística utilizou-se o programa Epi-info 7, cujos dados foram sistematizados em tabelas. A população foi composta por 26 pais e/ou responsáveis por adolescentes com TEA e atendidos pela Associação de Pais e Amigos do Autista.

O estudo obteve aprovação pelo Comitê de Ética em Pesquisas da Universidade Federal de Mato Grosso do Sul (UFMS), com parecer de aprovação número 709.626.

\section{RESULTADOS E DISCUSSÃO}

Os dados sobre sexo dos adolescentes com TEA revelaram que a maioria era do sexo masculino $(84,7 \%)$, conforme estudo sobre a prevalência para o transtorno no Brasil (PAULA, et al., 2011).

Observou-se que 53,9\% dos adolescentes estão no início deste período de vida e que uma importante parcela destes jovens não frequentou a escola, totalizando $42,31 \%$, conforme demonstrado pela Tabela 1 . Faz-se necessário ressaltar que a privação da convivência em ambiente educacional formal resulta em 
implicações negativas, de modo que o desenvolvimento sóciocognitivo é fortemente prejudicado, com implicações atuais e futuras (BRASIL, 2010).

Tabela 1 - Dados sociais e culturais de adolescentes com TEA, em Campo Grande, MS (N=26), 2020

\begin{tabular}{|c|c|c|}
\hline Variável & $\mathbf{N}$ & $\%$ \\
\hline Sexo & 22 & 84,70 \\
Masculino & 4 & 15,30 \\
\hline Feminino & $\mathbf{2 6}$ & $\mathbf{1 0 0 , 0}$ \\
\hline TOTAL & 14 & 53,90 \\
\hline Faixa etária & 12 & 46,10 \\
$10-14$ & $\mathbf{2 6}$ & $\mathbf{1 0 0 , 0}$ \\
$15-19$ & 13 & 50,0 \\
\hline TOTAL & 2 & 7,69 \\
\hline Frequência à escola & 11 & 42,31 \\
\hline Regular & $\mathbf{2 6}$ & $\mathbf{1 0 0 , 0}$ \\
\hline Especial & & \\
\hline Não frequenta & TOTAL &
\end{tabular}

Fonte: os autores (2020).

De acordo com a narrativa dos pais e/ou responsáveis, a ausência dos adolescentes ao ambiente escolar foi justificada pela falta de adaptação à escola regular, presença de comportamentos de agitação e agressividade, de modo a limitar a interação entre os pares e aquisição de experiências importantes para o desenvolvimento psicossocial.

Mesmo sendo citada pelos participantes deste estudo como opção somente no caso dos adolescentes não se adaptarem à escola regular, não é possível afirmar que a escola especial traz mais benefícios a pessoa com TEA, quando comparada com o modelo regular, sendo que a escolha deve levar em consideração as características pessoais de cada indivíduo, suas dificuldades e potencialidades (BOSA, 2006).

Em estudo comparativo sobre a realidade da educação especial entre os países da Itália e Brasil, observouse que há diferenças entre ambos os países em relação aos aspectos de formação profissional e atuação com estudantes com deficiência. Significativa ampliação da quantidade de alunos especiais no ensino comum, eliminação das classes especiais, centralização de percursos para formação docente e plano de trabalho com participação efetiva de diversos profissionais e da família, trabalho compartilhado em sala de aula, são as principais características do ensino especial italiano. Em relação à realidade brasileira, observa-se a existência de estudantes com deficiência em salas de ensino comum e especiais, diversidade quanto à formação docente, centralização do plano de trabalho no professor especializado e enfoque em trabalho diretivo para o estudante (ELOY; COUTINHO, 2020).

0 acesso à educação constitui-se direito inalienável e incondicional, efetivado a partir do processo de escolarização em seus diversos níveis, desde a educação básica até a superior, de modo a possibilitar a inclusão escolar, contemplando as especificidades do estudante e o convívio com seus pares. 0 desenvolvimento de sistema inclusivo deve enfocar o desenvolvimento global do estudante com TEA, incluindo potencialidades e dificuldades, com uso de recursos pedagógicos diversificados e fomentar aspectos da formação docente, com a constante qualificação dos profissionais envolvidos (BRASIL, 2015).

Conforme pesquisa realizada por Rocha et al., (2018), as fragilidades frequentemente relatadas por familiares e educadores no contexto do TEA poderiam ser solucionadas, a partir da criação de ambientes que favoreçam trocas de conhecimento com outros profissionais da educação e saúde e fomento de novos saberes que atendam às peculiaridades desta população. 
O estudante com deficiência possui direito ao Atendimento Educacional Especializado, que objetiva complementar a formação com uso de programas de enriquecimento curricular, ensino de linguagens, meios específicos de comunicação/sinalização e tecnologias que se adequem às singularidades de cada caso (BRASIL, 2015).

Frente aos aspectos que podem dificultar o processo de inclusão escolar, a presença de comorbidades no TEA é um fator a ser considerado e influencia no desenvolvimento psicossocial do adolescente. Dentre as principais comorbidades psiquiátricas presentes em pessoas no espectro do autismo estão as perturbações de humor, hiperatividade com déficit de atenção, ansiedade e esquizofrenia (RAMOS; XAVIER; MORINS, 2012).

O presente estudo identificou que $57,69 \%$ desta população apresentaram comorbidades, podendo estas se relacionarem com outros agravos que apresentem como consequência o atraso do desenvolvimento neuropsicomotor.

A Tabela 2 representa os aspectos econômicos das famílias, foram relacionados com a renda familiar bruta e com o número de dependentes, demonstrando que a maior parte das famílias tinha renda entre 2.1 e 5 salários mínimos (38,46\%). A partir destes dados pode-se realizar análise do contexto social e da interação em família, a partir de elementos diretamente relacionados ao poder aquisitivo e número de integrantes, o que permite identificar características relacionadas com a vulnerabilidade social do adolescente no espectro do autismo, incluindo acesso à educação, cultura, esporte e lazer (PHEBO; ROBIM, 2012; BRASIL, 2015).

Tabela 2 - Dados econômicos de adolescentes com TEA, em Campo Grande, MS (N=26), 2020

\begin{tabular}{|c|c|c|}
\hline \multicolumn{2}{|c|}{ Variável } & N \\
\hline Renda (salário mínimo) & 7 & 26,92 \\
Até 2 & 10 & 38,46 \\
2.1 à 5 & 8 & 30,77 \\
Maior 5 & 1 & 3,85 \\
\hline Não respondeu & $\mathbf{2 6}$ & $\mathbf{1 0 0 , 0}$ \\
\hline TOTAL & 2 & 7,60 \\
\hline Dependentes & 24 & 92,4 \\
\hline Até 2 & $\mathbf{2 6}$ & $\mathbf{1 0 0 , 0}$ \\
\hline 3 ou mais & 24 & \\
\hline TOTAL &
\end{tabular}

Fonte: os autores (2020).

Em relação ao integrante familiar que forneceu respostas a este estudo, houve destaque para a participação das mães (88,55\%), sugerindo que elas estão mais presentes e envolvidas com o tratamento dos filhos e, em alguns casos, deixaram de exercer diversas atividades pessoais para assumir responsabilidades diante do cuidado com o filho com o transtorno.

A responsabilidade com os cuidados da pessoa com deficiência centrada em apenas um membro familiar pode ser importante estressor, considerando as alterações emocionais e comportamentais de determinados adolescentes com TEA (SCHMIDT; BOSA, 2007; SIFUENTES, 2007). A intensa demanda com cuidados diários associada às dificuldades próprias do transtorno podem fazer com que o cuidador principal fique insensível à determinadas necessidades do adolescente, prejudicando o desenvolvimento individual e a interação familiar (SILVA et al., 2002).

A dinâmica familiar da pessoa com TEA também é alterada quando existe a presença de irmãos, considerando que importantes características devem ser observadas pois determinados aspectos podem prejudicar ou facilitar a interação familiar. Contextos familiares em que irmãos assumem função de cuidador, com responsabilidades inadequadas para a idade, estão mais vulneráveis a apresentar 
problemas de comportamento, no entanto, quando não possuem importantes responsabilidades, mas participam de maneira ativa na rotina, colaboram com a aquisição de habilidades socioafetivas (ROSS; CUSKERLLY, 2006).

Neste estudo, 92,4\% das famílias possuíam mais de 3 dependentes, sugerindo que este é um aspecto que deve ser amplamente observado nos projetos terapêuticos e educacionais, a fim de que as famílias recebam orientação que favoreçam o desenvolvimento intrafamiliar.

Reconhecidas as singularidades do contexto familiar de pessoas no espectro do autismo, é fundamental que equipes de saúde e educadores desenvolvam intervenções que contemplem a construção e consolidação de vínculos com pessoas com TEA e seus familiares, garantindo o cuidado contínuo e desenvolvimento global da pessoa com deficiência (BRASIL, 2015).

\section{CONSIDERAÇÕES FINAIS}

Os elementos sociais, culturais e econômicos de adolescentes com TEA pesquisados neste estudo fornecem importante perspectiva sobre características desta população no cenário brasileiro. No contexto educacional, é notável que as limitações decorrentes do TEA carecem de estratégias de abordagem e intervenção que vão além dessa classificação, devendo ser consideradas as singularidades individuais.

A inclusão social da pessoa com deficiência é um direito, mas necessita de articulação de diferentes segmentos sociais para sua plena consolidação. E neste cenário, a escola é fundamental para acesso às políticas públicas e garantia de direitos, no entanto, constitui eixo a ser fortalecido.

Quando a pessoa no espectro do autismo não tem acesso à educação inclusiva, seu potencial (intelectual e social) fica prejudicado, afetando de maneira singular o exercício pleno de sua cidadania. Apesar do exercício da cidadania envolver diversos aspectos, é salutar a participação familiar para superação das fragilidades inerentes ao cotidiano da pessoa com TEA.

O protagonismo familiar e da pessoa com TEA deve ser estimulado nas diferentes abordagens assistenciais, a partir de investimentos em instrumentalização das equipes de saúde com contínua capacitação, fazendo uso de metodologias ativas de aprendizagem, de modo a potencializar a inclusão social.

No âmbito educacional, investimentos constantes no aprimoramento de repertórios profissionais dos educadores com uso de ferramentas contextualizadas e adaptadas à pessoa no espectro do autismo mostram-se estratégias positivas para inclusão escolar. A valorização de momentos que favorecem a interação entre os profissionais (rodas de conversa, dinâmicas de grupos, oficinas, diagnóstico social, entre outras estratégias) é fundamental para surgimento de novos saberes e fazeres na prática com o estudante com TEA.

A abordagem de diferentes aspectos da realidade de pessoas no espectro do autismo representa favorecer a troca de experiências, apropriar-se da expertise profissional em diferentes cenários, de modo a fomentar novos conhecimentos que respondam às demandas psicossociais apresentadas por esta população.

\section{REFERÊNCIAS}

[1] AMERICAN PSYCHIATRIC ASSOCIATION. Diagnostic and statistical manual of mental disorders. 5. ed. Arlington, VA: American Psychiatric Publishing, 2013.

[2] AYDOS, V. Agência e subjetivação na gestão de pessoas com deficiência: a inclusão no mercado de trabalho de um jovem diagnosticado com autismo. Horizontes Antropológicos, Porto Alegre, ano 22, n. 46, p. 329-358, 2016.

[3] BOSA, C. A. Autismo: intervenções psicoeducacionais. Revista Brasileira de Psiquiatria, São Paulo, v. 28, p. $47-53,2006$.

[4] BRASIL. Ministério da Saúde. Secretaria de Atenção à Saúde. Departamento de Ações Programáticas Estratégicas. Linha de cuidado para a atenção às pessoas com transtornos do espectro do autismo e suas famílias na rede de atenção psicossocial do SUS. Brasília: Ministério da Saúde, 2013. 
[5] BRASIL. Ministério da Saúde. Secretaria de Atenção à Saúde. Departamento de Ações Programáticas Estratégicas. Linha de cuidado para a atenção às pessoas com transtornos do espectro do autismo e suas famílias na rede de atenção psicossocial do SUS. Brasília: Ministério da Saúde, 2015.

[6] BRASIL. Ministério da Saúde. Secretaria de Atenção em Saúde. Departamento de Ações Programáticas Estratégicas. Diretrizes nacionais para a atenção integral à saúde de adolescentes e jovens na promoção, proteção e recuperação da saúde. Brasília: Ministério da Saúde, 2010.

[7] COSSIO, A. P; PEREIRA, A. P. S.; RODRIGUEZ, R. C. Benefícios da intervenção precoce para a família de crianças com Transtorno do Espectro do Autismo. Revista Educação Especial, v. 31, n. 60, p. 9 - 20, 2018.

[8] CURSINO, I. G.; CURSINO, R. S. T. F; VIEIRA, S. C. M. Qualidade de vida de cuidadores de adolescentes com Transtorno do Espectro Autista: uma revisão da literatura. Adolescência e Saúde, v.13, n. 2, p. $67-78,2016$.

[9] DANTAS, K.O.; NEVES, R. F.; RIBEIRO, K. S. Q. S.; BRITO, G. E. G.; BATISTA, M. C. Repercussões do nascimento e do cuidado de crianças com deficiência múltipla na família: uma metassíntese qualitativa. Cadernos de Saúde Pública, v. 35, n. 6, p. 1-19, 2019.

[10] ELOY, A. C. M.; COUTINHO, L. C. S. O direito à educação na perspectiva da pedagogia históricocrítica e a educação especial. Revista Educação Especial, v. 33, 2020.

[11] FARO, K. C. A.; SANTOS, R. B.; BOSA, C. A.; WAGNER, A.; SILVA, S. S. C. Autismo e mães com e sem estresse: análise da sobrecarga materna e do suporte familiar. Psico, v. 50, n. 2, 2019.

[12] KERNIER, N.; CUPA, D. Adolescência: muda psíquica à procura de continentes. Ágora (Rio de Janeiro), v. 15, número especial, p. 453 - 467, dez. 2012.

[13] MANFEZOLLI, R. R. Olha eu já cresci: a infantilização de jovens e adultos com deficiência mental, 2004. Dissertação (mestrado em educação) - Faculdade de Educação, Universidade Metodista de Piracicaba, Piracicaba, 2004.

[14] ORGANIZAÇÃO MUNDIAL DE SAÚDE (OMS). Saúde do Adolescente. Disponível em: URL: https://www.who.int/health-topics/adolescent-health\#tab=tab_1

[15] PAPALIA, D.E.; OLDS, S; FELDMAN, R. D. O mundo da criança: da infância à adolescência.11ํo ed. Porto Alegre: Artmed, 2010.

[16] PASSERINO, L. M.; SANTAROSA, L. C. Interação social no autismo em ambientes digitais de aprendizagem. Psicologia: reflexão e crítica, v. 20 (1), p. 54- 64, 2007.

[17]

PAULA, C.S.; RIBEIRO, S. H.; FROMBONE, E.; MERCADANTE, M. T. Prevalence of pervasive developmental disorder in Brazil: a pilot study. Journal of Autism and Developmental Disorders, v. 37, n. 7, p. 1394 - 1395, 2011.

[18] PHEBO, L. B; ROBIM, M. Esporte: um direito para o desenvolvimento humano. In: NOGUEIRA, K.T. (coord.). FERREIRA, E. L.; VASCONCELOS, M. M. (Orgs.). Adolescência: série pediatria. Rio de Janeiro: Guanabara Koogan, 2012, p. 500 - 511.

[19] PINO, A. As marcas do humano: as origens da constituição cultural da criança na perspectiva de Lev A. Vigotski. São Paulo: Cortez, 2005.

[20] RAMOS, J; XAVIER, S; MORINS, M. Perturbações do espectro do autismo no adulto e suas comorbilidades psiquiátricas. Revista do Serviço de Psiquiatria do Hospital prof. Doutor Fernando Fonseca, EPE, vol. 10, n.2, p. 09 - 23, 2012.

[21] ROCHA, A. N. D. C.; COPOBIANCO, N. A. N.; BRITO, L. B.; SANTOS, A. R. dos. Intervenção junto a indivíduos com transtorno do espectro do autismo: a percepção do profissional. Revista Educação Especial, p. 417-430, 2018.

[22] ROSS, P.; CUSKELLY, M. Adjustment, siblings problems and coping strategies of $\backslash$ brothers and sisters of children with autism spectrum disorders. Journal of Intellectual and Developmental Disability, v. 31, n.2, p. 77 - 86, 2006.

[23] SANINI, C.; SIFUENTES, M.; BOSA, C. A. Competência Social e autismo: o papel do contexto da brincadeira com pares. Psicologia Teoria e Pesquisa, v. 29, n.1. p. 99-105, 2013. 
[24] SANTOS, M. S.; XAVIER, A. S.; NUNES, A. I. B. L. Adolescência: aspectos históricos e biopsicossociais. In: Psicologia do desenvolvimento: teorias e temas contemporâneos. Brasília: Liber Livro, 2009, p. $109-124$.

[25] SANTROCK, J. W. Adolescência. 14. ed. Porto Alegre: AMGH, 2014.

[26] SCHMIDT, C.; BOSA, C. Estresse e auto-eficácia em mães de pessoas com autismo. Arquivos Brasileiros de Psicologia, v. 59, n. 2, p. 179 - 191, 2007.

[27] SIFUENTES, M. As características da coparentalidade em pais de crianças com autismo em idade préescolar. 2007. Dissertação (Programa de Pós-graduação em Psicologia) - Universidade Federal do Rio Grande do Sul, Porto Alegre, Brasil, 2007.

[28] SILVA, S.S. da C. LE PENDU, Y.; PONTES, F. A. R.; DUBOIS, M. Sensibilidade materna durante o banho. Psicologia: teoria e pesquisa, v. 18, n. 3, p. 345 - 352, set. / dez. 2002.

[29] SPRINTHALL, N. A.; COLLINS, W. A. Psicologia do adolescente: uma abordagem desenvolvimentista. 3. ed. Lisboa: Fundação Calouste Gulbenkian. Serviço de Educação e Bolsas, 2003.

[30] SPROVIERI, M. H. S. Família e deficiência. In: ASSUMPÇÃo JÚNIOR, F. B; TARDIVO, L. S. L. P. C. (coord.). Psicologia do excepcional: deficiência física, mental e sensorial. Rio de Janeiro: Guanabara Koogan, 2008.

[31] TEDESCO, M. R. M.; VILLELA, S. M. F. V.; MANZONI, C. R. T.; IGLESIAS, S. H. Atenção à saúde do adolescente com deficiência. In: SÃO PAULO. Secretaria da Saúde. Manual de atenção à saúde do adolescente. Coordenação de Desenvolvimento de Programas e Políticas de Saúde - CODEPPS. São Paulo: SMS, 2006, p. 117 - 119.

[32] UNICEF. Fundo das Nações Unidas para a Infância. Situação mundial da infância 2011. Adolescência: uma fase de oportunidades, p. $22-68,2011$. 


\section{Capítulo 12}

Direito internacional dos direitos humanos, crise econômica e migrações de venezuelanos para Roraima $_{25}$

\section{Marcos Joel de Melo Santos}

Resumo: A proposta deste artigo é analisar, à luz do direito internacional dos direitos humanos, o início do fluxo migratório de venezuelanos para o estado de Roraima, entre os anos de 2014 e 2016. Diariamente, centenas de venezuelanos abandonavam seu país pela cidade fronteiriça de Santa Elena do Uairén, para tentar uma vida melhor no Brasil. O pequeno município de Pacaraima, em Roraima, porta de entrada dos imigrantes, se transformou numa espécie de campo de refugiados para venezuelanos carentes. A maioria fugia das más condições de vida, das violações de direitos humanos e dos reflexos da profunda crise econômica em curso naquele país. A situação mais grave era a dos índios venezuelanos da etnia Warao, encontrados mendigando nas ruas de Boa Vista, após viajarem 925 quilômetros entre as aldeias no estado Delta Amacuro, na Venezuela, e a capital roraimense. 0 estudo é complementado por pesquisa bibliográfica de dados secundários na legislação, em jornais locais, na doutrina sobre direito internacional dos direitos humanos, e em tratados internacionais acerca de direitos humanos e migração dos quais o Brasil é signatário. 0 artigo destaca ainda a inexistência de abrigos nas cidades de Boa Vista e Pacaraima no período analisado, as dificuldades para a concessão do refúgio, a política de deportação de estrangeiros e as violações a normas e tratados de direito internacional por autoridades brasileiras no início da crise migratória.

Palavras-Chave: Direito Internacional dos Direitos Humanos; Crise econômica na Venezuela; Imigrantes venezuelanos em Roraima. 


\section{INTRODUÇÃO}

Entre os anos de 2014 e 2016 a crise econômica na Venezuela ultrapassou as fronteiras e chegou ao Brasil. Mensalmente, centenas de estrangeiros cruzavam os limites entre os dois países pelo estado de Roraima, em busca de melhores oportunidades do lado brasileiro. Acampados nas ruas da cidade fronteiriça de Pacaraima/RR, ou em frente ao prédio sede da Polícia Federal (PF) - na capital, Boa Vista - eram vistos aglomerados desde as primeiras horas da manhã, em filas quilométricas, enquanto aguardavam por documentos que os habilitassem a permanecer no Brasil. Entre os imigrantes haviam pessoas muito qualificadas, não absorvidas pelo mercado de trabalho venezuelano, e uma quantidade maior de migrantes com baixa qualificação formal - vivendo de esmolas nos semáforos, dedicados à demonstração de artes circenses nas ruas, à limpeza de para-brisas de veículos, à venda de artesanato e pequenos itens, ou sobrevivendo da prostituição.

O número de venezuelanos que solicitaram refúgio em Roraima cresceu 22.122\% nos três anos analisados. Em 2014 foram apenas 9 solicitações, em 2015 o índice chegou a 230 e disparou para 2.230 em 2016, de acordo com a Polícia Federal. Só neste último ano, mais de 2 mil venezuelanos foram à sede da PF em Boa Vista para pedir a condição de refúgio. (COSTA, 2017). 0 aumento coincidiu com a fase inicial do agravamento da crise econômica na Venezuela. Remédios, papel higiênico, e itens básicos como leite e carne passaram a ser difíceis de encontrar. A situação humanitária dos indígenas da etnia Warao, um dos povos mais antigos do Delta do Orinoco, na nação caribenha, era ainda mais dramática. Os índios percorriam os 925 quilômetros que separavam suas aldeias da capital roraimense, para sobrevier de pedidos e doações no Brasil (SANTOS, 2016).

A cidade de Pacaraima, na fronteira com o país vizinho, virou uma espécie de campo de refugiados para venezuelanos fugindo da crise. Famílias inteiras desnutridas, nas ruas, em busca de alimentos. Em 2016 não existia em Roraima programas sociais destinados aos imigrantes, nem centros específicos de cuidado. A política adotada pelas instâncias governamentais responsáveis pelo controle migratório era a deportação. Naquele ano, a ONG internacional de defesa dos direitos humanos Human Rights Watch (HRW, 2018) classificou a situação dos venezuelanos no Brasil como "muito grave".

\section{A CRISE ECONÔMICA NA VENEZUELA}

A crise econômica na Venezuela aconteceu após um extenso período de prosperidade. Durante as décadas de 1950 a 1970 o país desfrutou de um ritmo de crescimento econômico alto e estável, com uma das taxas de inflação mais baixas do mundo. Entre 1950 e 1979, o crescimento médio anual do Produto Interno Bruto (PIB) venezuelano foi de 6,26 \%, enquanto que a inflação média para o período foi de 3,5\% (PUENTE, 2007).

Na década de 1980 a situação começou a mudar. Os problemas macroeconômicos básicos, recessão, inflação, desemprego, desequilíbrio externo e fiscal, passaram a tomar grandes proporções. A inflação que se mantivera em taxas inferiores às internacionais ultrapassou marcas históricas. A taxa de desemprego e a desvalorização cambial mostraram grande variabilidade.

De taxas de crescimento médio superiores a $6 \%$ anuais, combinadas com inflações de $3 \%$ ao ano, a Venezuela passou a sofrer forte recessão econômica com alta inflação, em torno de $46 \%$ ao ano, a partir da década de 1990. Nas três últimas décadas, não só a economia venezuelana deixou de estar entre as mais exitosas, como passou a ocupar os últimos lugares entre as economias latino-americanas (ENERO, 2016).

O último grande avanço da economia da nação caribenha ocorreu nos idos de 2006, sob o impacto positivo do aumento do preço do petróleo (US\$ 56,4/barril), o PIB venezuelano aumentou pelo $12^{\mathrm{o}}$ trimestre consecutivo, alcançando o índice de 10,3\%. Durante mais de dez anos o petróleo encheu os cofres do Governo de Caracas. Mas a queda do preço do barril, e a falta de investimento, levaram o país a uma situação caótica. A situação passou a refletir as oscilações e dificuldades macroeconômicas de uma economia na qual, no início do século XXI, o petróleo representava 28\% do PIB e cerca de $75 \%$ das exportações e da receita fiscal (CANO, 2002).

Membro da Organização dos Países Exportadores de Petróleo (OPEP), a Venezuela dispõe das maiores reservas de petróleo do mundo, cerca de 300 milhões de barris. 0 combustível fóssil alimentou mais de uma década de prosperidade. Tornou-se o motor da economia, chegando a representar 96\% das exportações do país. Mas o governo não fez poupança, e os investimentos em infraestrutura não foram suficientes. As reservas e divisas utilizadas para pagar o deficit público, bem como as importações, minguaram. Com a queda do petróleo o período de prosperidade acabou. 
O preço do barril caiu a níveis históricos. Em 2016 o barril foi cotado em dois terços do que valia dois anos antes. Sua queda arrastou a economia venezuelana para baixo. Sem diversificar sua atividade econômica, o país governado por Nicolás Maduro viu sua dívida externa atingir a cifra de 250 milhões de dólares em abril de 2015, de acordo com a empresa de assessoria econômica Ecoanalítica.

O Produto Interno Bruto (PIB) que havia caído 5,7\% em 2015, despencou ainda mais, cerca de 19\% em 2016. A inflação que já era a mais alta do mundo, com uma taxa de 180\%, ao ano em 2015 (de acordo com o Governo local), atingiu $800 \%$ no ano seguinte, segundo o Fundo Monetário Internacional (FMI). 0 governo do presidente Nicolás Maduro atribuiu a culpa pela situação econômica da Venezuela a uma "guerra econômica" liderada por adversários políticos com a ajuda dos Estados Unidos (REUTERS, 2017).

A capacidade do país em honrar a dívida e defender o valor de sua moeda diminuía rapidamente. Em dezembro de 2016, no câmbio oficial do país, um real valia cerca de três bolívares. Na fronteira com o Brasil, contudo, no câmbio negro da cidade de Santa Elena do Uairén, um real era trocado por quatrocentos e cinquenta bolívares. No mesmo período, com a nota de um dólar, era possível adquirir dez bolívares no mercado oficial. Enquanto isso, no mercado paralelo do município venezuelano, a mesma cédula de dólar comprava cerca de mil e quinhentos bolívares.

Nesse ínterim, para dificultar a fuga de capitais, o governo Maduro impediu que empresas venezuelanas tivessem suas contas em moedas mais estáveis, como o real ou o dólar. A vedação dificultava a importação de bens e matérias-primas, o que por sua vez, provocava escassez de produtos nas lojas, supermercados e farmácias. Diariamente, longas filas se formavam para a compra de itens básicos de higiene e alimentação, o que levou a Venezuela a decretar estado de "emergência econômica".

Além disso, o governo estadunidense passou a impor sanções à economia venezuelana que agravariam a crise e forçariam o país latino a reduzir a quantidade de petróleo exportado (SOUZA, 2016). Sem dinheiro, o governo venezuelano reduziu a compra de itens básicos à população, agravando ainda mais o desabastecimento dos mercados e, consequentemente, a crise. A capital, Caracas, até então a cidade mais bem abastecida, passou a conviver também com a escassez de produtos básicos. Segundo o instituto de pesquisas Datanálisis, o percentual de desabastecimento atingiu 82,8\% em 2016, favorecendo a diáspora de venezuelanos que tentariam a sobrevivência no Brasil.

\section{PEDIDOS DE REFÚGIO E MIGRAÇÃO ECONÔMICA}

Entre 2014 e 2016 as crises econômica e política na Venezuela se agravou bastante. Em 2016, o presidente da EurasiaGroup, empresa global de consultoria de riscos políticos, Ian Bremmer, afirmou que $87 \%$ dos venezuelanos declararam não ter dinheiro para comprar comida (PRAZERES, 2016). A situação foi apontada como o principal motivo para o êxodo do país.

Muitos desembarcaram em Roraima, em busca de emprego, comida e produtos de primeira necessidade. Dados divulgados pelo Ministério da Justiça e Segurança Pública apontaram que, no período analisado, os pedidos de refúgio de venezuelanos em Roraima cresceu mais de $22.000 \%$. 0 contínuo aumento coincidiu com o agravamento da crise humanitária. No segundo semestre de 2016, mais de 30 mil imigrantes já haviam cruzado a fronteira brasileira, de acordo com o governo estadual. Esta contagem, entretanto, não levou em consideração os venezuelanos em visita ao Brasil apenas para comprar itens básicos, que não mais existiam nas padarias e supermercados locais.

Naquele ano, o número de pedidos de refúgio de venezuelanos em Roraima superou o dos cinco anos anteriores somados. A fila de espera para oficializar a documentação só terminaria em 2018. De acordo com o Ministério da Justiça e Segurança Pública, apenas em 2016, foram 2.310 solicitações, contra 1.096 entre os anos de 2010 e 2015. O número foi quatro vezes maior que o total de haitianos refugiados no Acre, após o terremoto de 2010.

O refúgio, enquanto instituto, foi estabelecido pela Convenção Relativa ao Estatuto dos Refugiados das Nações Unidas de 1951, consiste num tipo de visto concedido a quem alega ser perseguido em outros países, em função da raça, religião, opinião política, posição social, dentre outros motivos (ONU, 1951). No Brasil, o dispositivo incorporado ao ordenamento pátrio em 1961, determina que os pedidos de refúgio seriam avaliados pelo Comitê Nacional para os Refugiados (CONARE), órgão colegiado vinculado ao Ministério da Justiça, responsável por deliberar sobre as solicitações de reconhecimento da condição de refugiado. 
Em 2016 os pedidos eram analisados por meio de entrevista dos solicitantes, a partir das quais se verificava se estes eram ou não amparados pelas leis brasileiras e convenções internacionais das quais o Brasil é signatário. Os pedidos continuam funcionando como um indicador da imigração para o Brasil. Outro indicador era o SINCRE (Sistema Nacional de Controle de Registro de Estrangeiros), administrado pela Polícia Federal, cuja função era realizar o registro nacional de estrangeiro (RNE). Documento que até aquele ano atestava a identidade de estrangeiros com residência temporária ou permanente no território brasileiro.

Entre os anos de 2014 e 2016, imigrantes venezuelanos passaram a adentrar o território nacional de diversas formas e por diversos motivos. A maioria, no entanto, chegava ao Brasil fugindo da crise financeira, em busca de uma fonte de renda mais segura, inclusive pra remeter para seus familiares (PRAZERES, 2016). Alguns entravam no território nacional com vistos de turista, outros, em busca de emprego, conseguiram entrar com autorização do extinto Ministério do Trabalho; uma outra parte solicitava refúgio, categoria especial de migração regulamentada pela Lei 9.474/97.

De acordo com a referida lei:

\section{Art. $1^{\circ}$ Será reconhecido como refugiado todo indivíduo que:}

I - devido a fundados temores de perseguição por motivos de raça, religião, nacionalidade, grupo social ou opiniões políticas encontre-se fora de seu país de nacionalidade e não possa ou não queira acolher-se à proteção de tal país;

II - não tendo nacionalidade e estando fora do país onde antes teve sua residência habitual, não possa ou não queira regressar a ele, em função das circunstâncias descritas no inciso anterior;

III - devido a grave e generalizada violação de direitos humanos, é obrigado a deixar seu país de nacionalidade para buscar refúgio em outro país. (grifo nosso)(BRASIL, 1997)

Além de regulamentar o Estatuto dos Refugiados da Organização das Nações Unidas (ONU), a Lei 9.474/97 indicava as situações previstas para a concessão do refúgio: perseguição política por motivos como raça, religião, nacionalidade, grupos sociais, conflitos armados, violência generalizada, ou violação massiva dos direitos humanos.

Muitos operadores do direito, vinculados a entidades responsáveis pelo controle migratório em Roraima, numa interpretação restritiva da regra, consideravam que a norma não previra explicitamente o direito ao refúgio por questões econômicas. Tal entendimento desconsiderava a fome, a falta de moradia, de trabalho, de assistência à saúde, e os reflexos da grave crise econômica venezuelana como violações de direitos humanos.

Os solicitantes de refúgio poderiam ter acesso provisório à Carteira de Trabalho e Previdência Social (CTPS) e ao CPF, e permanecer com os documentos até que o pedido fosse julgado. Para consegui-los em definitivo, porém, o solicitante precisaria provar ser alcançado por algum dos itens previstos na Lei. Com a interpretação restritiva dada à norma, os estrangeiros que se configurassem como migrantes econômicos, e tivessem seus pedidos rejeitados, deveriam encontrar outras formas de permanecer no Brasil legalmente, sob o risco de serem deportados.

A maior parte dos pedidos de refúgio, na prática, tinha razões econômicas. 0 que provavelmente explica o baixo índice de aprovação das solicitações até 2016. Dos 531 pedidos realizados até aquele ano, apenas nove haviam sido aprovados, enquanto outros 26 foram indeferidos. Em 2016 os pedidos de refúgio cresceram tanto que mesmo a Polícia Federal tendo reforçado o efetivo de servidores do posto de Pacaraima/RR, o referido ponto de controle migratório já estava distribuindo senhas para abril do ano seguinte (PAÉZ, 2016). Com a grande quantidade de solicitações, os prazos para análise também ficaram mais longos, e só diminuiriam dois anos depois, a partir da implantação de sistemas de inteligência que permitiriam avaliações em bloco.

\section{A CRISE HUMANITÁRIA DOS IMIGRANTES VENEZUELANOS EM RORAIMA}

Enquanto aguardavam o resultado dos pedidos de refúgio, milhares de venezuelanos dormiam ao relento nas ruas de Boa Vista/RR e Pacaraima/RR. Entre estes haviam homens e mulheres de classe média, profissionais liberais e pequenos comerciantes, cujas empresas quebraram na Venezuela. A Organização 
Não Governamental Human Rights Whatch (HRW, 2018), indicou que muitos sequer conseguiram inserção no incipiente mercado de trabalho de Roraima. Outros, mais qualificados, passaram a ser contratados para atividades consideradas subalternas, como pedreiros, jardineiros e auxiliares de serviços gerais. Indígenas e trabalhadores com menor qualificação formal encontram as maiores dificuldades.

Com o crescimento repentino, e sem precedentes da imigração, o município de Pacaraima/RR, de pouco mais de dez mil habitantes, transformou-se num novo ponto de tensão na Amazônia. Em 2016 já existiam duas favelas no município, formadas por brasileiros, mas, principalmente por homens, mulheres e crianças venezuelanas. Prostituição e criminalidade passaram a ser problemas comuns. Nos primeiros seis meses daquele ano, os atendimentos a venezuelanos nos hospitais da cidade superaram o de atendimentos a brasileiros, bem como o somatório de todos os procedimentos do ano anterior, conforme dados da Secretaria Municipal da Saúde. Os casos de urgência e emergência passaram a liderar as ocorrências, sinalizando deficiências na atenção primária e nos serviços de saúde preventiva na Venezuela.

A pequena cidade, embora fosse a porta de entrada dos venezuelanos no Brasil, continuava sem infraestrutura para absorver o número de imigrantes. Com a disputa por recursos escassos, muitos confrontos passaram a ocorrer. Agressões, até mesmo por leitos nos hospitais, por vagas no sistema público de ensino, e por oportunidades de emprego formaram o pano de fundo para reações xenofóbicas e ataques físicos contra venezuelanos que aconteceriam nos anos seguintes.

Sem o acolhimento desejado em Pacaraima, muitos passaram a seguir viagem para Boa Vista/RR, distante 230 quilômetros da fronteira venezuelana. De acordo com um ex comandante do Corpo de Bombeiros e Defesa Civil de Roraima, havia claros indícios da presença de coiotes (agenciadores clandestinos), cobrando valores extorsivos de pessoas já com poucos recursos, para transportá-las entre a região de Pacaraima e a capital roraimense (SANTOS, 2016).

\section{AS CONDIÇÕES DE SOBREVIVÊNCIA DOS ÍNDIOS WARAO EM BOA VISTA/RR E EM PACARAIMA/RR}

Dentre os imigrantes, a situação dos índios Warao configurava-se como a mais grave. Eles partiam das aldeias do Delta do Orinoco, na Venezuela, a pé, e viajavam de canoa, ônibus e carona, no percurso de 925 quilômetros até chegar à capital roraimense, onde chegavam desidratados e necessitados de atendimento médico. Ademais, a integração com a sociedade local sempre foi um obstáculo. Eles não possuíam vínculos étnicos ou identitários com os indígenas de Roraima. Sem abrigo, e sem afinidades culturais, o risco de marginalização e exposição a vulnerabilidade social da sua comunidade continuava premente.

Na Venezuela, os Warao remanescentes viviam em palafitas, no Parque Nacional Mariusa, no estado Delta Amacuro, às margens do Oceano Atlântico. Eles formam a segunda maior população indígena do país, com 36 mil indivíduos, atrás apenas da etnia Wayúu. Segundo autoridades locais, a presença deles no Delta do rio Orinoco, no nordeste da Venezuela, é datada de oito mil a nove mil anos, são, portanto, um dos povos mais antigos da região norte do continente sul-americano.

Os Warao são conhecidos como "os povos da canoa", e pela qualidade do seu artesanato. Exímios pescadores, os peixes fazem parte da sua subsistência e são a sua principal fonte de renda. Mas com o colapso da economia venezuelana não tinham para quem vender. A situação dos povos indígenas do Orinoco ficou muito difícil, suas terras estão salinizadas. 0 que planta não nasce! Estão esquecidos e passando fome, falta até água potável (SOUZA \& GONZALO, 2016).

Em Boa Vista e Pacaraima/RR, cidades roraimenses para onde migraram, até 2016 não existiam abrigos para acolher venezuelanos, tampouco indígenas. Sem lugar seguro para dormir, ocupavam terrenos baldios, áreas embaixo de árvores, ou casas abandonadas. Para conseguir água ou alimentos vendiam artesanato ou pediam esmolas nos cruzamentos. Em sua maioria eram idosos, notadamente mulheres. Em geral deixavam seus filhos sob os cuidados dos maridos e viajavam em busca de alguns trocados para garantir sua subsistência. Algumas crianças, contudo, acompanhavam as famílias, aumentando a situação de vulnerabilidade social.

Há relatos de que os indígenas eram revistados por agentes da guarda bolivariana (a polícia local) ao regressarem para a Venezuela, e que era comum os policiais ficarem com tudo o que conseguiram. Dinheiro, produtos de primeira necessidade, açúcar, farinha, e até papel higiênico, escassos no seu país natal, seriam supostamente recolhidos pelos agentes durante as abordagens.

De acordo com a Polícia Federal, poucos tinham passaporte, a maioria entrou no Brasil sem nenhum registro. Dos que possuíam o documento, alguns conseguiram o visto como turistas, o que permitia a 
permanência por até 90 dias por ano no Brasil, podendo ser prorrogado por igual período. Ao final do prazo, caso não tivesse deixado o país, o indígena poderia pagar uma multa de até $R \$ 827,75$, além de ser deportado.

\section{A POLÍTICA DE DEPORTAÇõES DO GOVERNO FEDERAL APLICADA AOS INDÍGENAS VENEZUELANOS}

Do início de 2014 a junho de 2016, 223 indígenas da etnia Warao foram deportados pela Polícia Federal. As deportações se intensificaram a partir de dezembro de 2015, quando 166 índios foram retirados das ruas, ou de casas abandonadas onde estavam abrigados em Boa Vista e Pacaraima, e obrigados a retornar para a Venezuela. Os que permaneciam no Brasil, com vistos temporários vencidos, recebiam, quando muito, um atendimento psicossocial muito precário. Muitos sequer eram atendidos, pela ausência ou irregularidade da documentação migratória. (SOUZA \& GONZALO, 2016).

A Polícia Federal fez a primeira deportação dos Warao em 10 de julho de 2014, retirando das ruas de Boa Vista, 28 pessoas em condições precárias de sobrevivência. 0 registro histórico sugere que a crise humanitária atingiu os indígenas antes mesmo do aumento do fenômeno migratório. Pelas normas vigentes, caberia à Fundação Nacional do Índio (FUNAI) identificá-los, o local de onde procedem, os motivos que os trouxeram à Roraima, dentre outros. A instituição, no entanto, nem sempre foi notificada para acompanhar o processo de deportação. A obrigatoriedade do acompanhamento decorre do fato de, embora sejam estrangeiros, sejam também indígenas.

Ironicamente, as medidas de proteção e cuidado adotadas pelos entes federativos brasileiros, aos quais caberia proteger o povo Warao, se limitaram basicamente à deportação. Dirigentes da PF justificavam a prática com a argumentação de que os índios, por serem estrangeiros, e estarem com a documentação de entrada no país irregular, além de dedicados à mendicância, estariam desenvolvendo atividades incompatíveis com a condição de turista.

Ao serem deportados, os indígenas eram entregues às autoridades migratórias venezuelanas em Santa Elena do Uiarén. Tal medida, contudo, se mostrava pouco efetiva. Algum tempo depois, pela dificuldade em conseguir alimentos na Venezuela, muitos acabavam voltando às ruas da capital, vagando pelas ruas da cidade, ou acampados provisoriamente em situações muito insalubres. Outros, tentavam driblar a deportação permanecendo em Pacaraima/RR. Sem qualquer assistência governamental, mulheres, idosos e crianças, inclusive, sobreviviam de doações da comunidade civil e de particulares. Ao pôr do sol, cruzavam a fronteira de volta para a Venezuela, onde armavam suas redes em qualquer lugar em que pudessem passar a noite.

À época, a Superintendência da PF em Roraima parece ter firmado entendimento de que os Warao não se encaixavam em quaisquer das classificações de pedido de refúgio no Brasil. 0 gestor em exercício do órgão, em entrevista ao jornal Amazônia Real, em 13 de junho de 2016, prestou a seguinte declaração: "Entendo, como cidadão, que há um problema social. Mas, como aplicador da lei, não podemos fugir dela. Perante o ordenamento jurídico brasileiro eles não são vistos como indígenas e, sim, como estrangeiros, e devem ser tratados como tais." A opinião do gestor, a partir de uma interpretação restritiva e equivocada da legislação migratória nacional, relativizava os direitos dos imigrantes, em face de uma suposta supremacia das normas internas sobre os direitos humanos, que "justificaria" a política de deportação dos indígenas.

0 "estrito cumprimento da lei" e o discurso de criminalização do ingresso dos indígenas no Brasil, pelo não cumprimento dos requisitos legais, potencializou ainda mais as vulnerabilidades sociais dessa comunidade, especialmente no que tange aos direitos de idosos e crianças. O Superintendente em exercício da PF em Roraima, no entanto, reiterava suas práticas com o seguinte argumento: "Existem leis de enquadramento humanitário, a Presidência da República fez uma norma referente aos haitianos. 0 haitiano que chega ao Brasil é albergado por um decreto presidencial. Não enxergo o indígena nessas condições humanitárias", disse ${ }^{26}$.

Ao contrário da opinião do ilustre servidor, entendemos, conforme Barreto (2013), que direitos indígenas são também direitos humanos e, portanto, independem do reconhecimento pelo Estado, prescindem da 
inserção em constituições e, até mesmo da existência de instrumentos que lhes assegurem contra-ataques, por ação ou por omissão.

Se os povos indígenas são iguais em dignidade e direitos, se a diversidade cultural e étnica compõe um legado comum da humanidade; se a suposta superioridade de uma cultura sobre a outra é cientificamente injustificável; se o exercício de um direito não deve estar submetido a nenhum tipo de discriminação, então, cabe às sociedades dominantes reparar os abusos que vêm sendo praticados contra os povos autóctones (GERSEM, 2006). Para tanto, temos que estender a eles o reconhecimento dos direitos fundamentais, de acordo com a Declaração Universal dos Direito do Homem, e com as leis internacionais de proteção aos direitos humanos (BARAZAL, 2001).

\section{A EMERGÊNCIA DO DIREITO INTERNACIONAL DOS DIREITOS HUMANOS NAS AÇÕES ESTATAIS PARA MITIGAR O SOFRIMENTO DOS IMIGRANTES VENEZUELANOS EM RORAIMA}

Em 17 de outubro de 2016, a então governadora do estado, Suely Campos, em que pese tenha reiterado ser do Governo Federal a responsabilidade com os imigrantes, editou, o decreto no 21.871 que criou, em caráter extraordinário, o Gabinete Integrado de Gestão Migratória (GIGM). 0 Gabinete, composto por 17 secretarias estaduais, sob a coordenação da Defesa Civil do Estado e do Corpo de Bombeiros, e integrado por membros convidados como a Polícia Federal e a Polícia Rodoviária Federal, tinha como objetivo planejar e executar ações de assistência aos imigrantes venezuelanos em Roraima.

As dificuldades para a atuação do Comitê, no entanto, decorriam não só da necessidade de articular harmonicamente as ações entre Secretarias, instâncias e órgãos estaduais, com olhares tão diferentes sobre o mesmo fenômeno, mas, fundamentalmente, do conhecimento superficial dos gestores e servidores dos órgãos que o compunha, sobre o alcance e a efetividade da Lei no 6.815 de 19 de agosto de 1980 (Estatuto do Estrangeiro), em face dos tratados e pactos internacionais de proteção aos imigrantes dos quais o Brasil era signatário, e dos direitos humanos fundamentais dispostos na Constituição Federal de 1988.

O extinto Estatuto do Estrangeiro (Lei no 6.815 de 19 de agosto de 1980), foi o diploma legal que até novembro de 2017 disciplinava a condição jurídica do imigrante no Brasil. 0 Estatuto previa diversas formas de ingresso e de permanência de estrangeiros em território brasileiro, oferecendo diversos tipos de vistos:

Art. 4o Ao estrangeiro que pretenda entrar no território nacional poderá ser concedido visto:

I - de trânsito;

II - de turista;

III - temporário;

IV - permanente;

$\mathrm{V}$ - de cortesia;

VI - oficial; e

VII - diplomático. (BRASIL, 1980)

Editado na vigência do regime militar, sua aplicação em Roraima pelas autoridades migratórias foi conflituosa. Direitos fundamentais, e a própria dignidade da pessoa humana, previstos na Carta Magna, foram minimizados nas interpretações restritivas de direitos que resultaram nas diretrizes adotadas pelo estado e por servidores federais em Roraima nas deportações em massa. Tais fatores foram ainda corroborados pela quase inexistência no estado - nos primeiros anos da crise - de ONGs de alcance nacional e/ou internacional, voltadas a proteção de vulneráveis, e da inexperiência destas mesmas autoridades no trato com situações que exigiam cuidado humanitário.

A situação dos venezuelanos no Brasil, e particularmente dos Warao, embora, numa análise estritamente dogmática, pudesse, eventualmente, não ser enquadrada nos critérios para a concessão de refúgio, previstos pelo Estatuto do Estrangeiro, numa interpretação lógico-sistemática, seria analisada de modo menos obtuso. Considerar-se-ia o disposto na Lei Federal no 9.474/97, que trata da implementação do Estatuto dos Refugiados, ou ainda nos diplomas legais que acompanham os tratados e pactos internacionais ratificados pelo Brasil, e que obrigam o poder público a assegurar aos nacionais e 
estrangeiros, sem qualquer tipo de discriminação, o respeito à dignidade humana, conforme insculpido no inciso III do Art. 1음 da Constituição Federal.

Ao mesmo tempo, bastaria uma rápida consulta pelas autoridades roraimenses nos regulamentos a muito disponíveis ao Direito Internacional dos Direitos Humanos, como o Estatuto dos Refugiados das Nações Unidas, de 1951, o Pacto Internacional de Direitos Civis e Políticos, de 1966, o Pacto Internacional dos Direitos Econômicos, Sociais e Culturais, de 1966, ou a Declaração Universal dos Direitos Humanos, de 1948, todos ratificados e elevados à condição de supremacia hierárquica constitucional pelo Estado brasileiro, para que fosse alterada a esdrúxula interpretação da norma e poupado mais sofrimento aos imigrantes.

Tal panorama só viria a ser alterado tardiamente, com a entrada da União no cenário migratório. 0 governo federal encaminhou a Roraima, entre os dias 24 e 26 de outubro de 2016, uma Comissão do extinto Ministério da Justiça e Cidadania para avaliar a situação dos venezuelanos. 0 órgão articulou-se com o Alto Comissariado da Organização das Nações Unidas para os Refugiados (ACNUR), com a Secretaria Nacional de Justiça e Cidadania e com o Departamento de Imigrações da Polícia Federal para conferir de perto o problema, e propor em conjunto, soluções que se transformariam no embrião da Operação Acolhida.

A entrada do governo federal no contexto da imigração venezuelana, culminou com a decretação de intervenção federal em Roraima em 2018, e viria representar uma nova reconfiguração jurídica da situação do estrangeiro (herança das concepções de segurança nacional, oriundas do regime militar), para a condição de migrante. A revogação do retrógrado Estatuto do Estrangeiro, e sua substituição pela Lei no 13.445 de 2017 (Lei de Migração), consentânea com os princípios de proteção e amparo dos direitos fundamentais, seria o primeiro passo normativo nesta direção.

A nova reconfiguração jurídica, promovida pela nova Lei de Migrações, parece ter abolido, ao menos por enquanto, interpretações limitantes acerca do alcance dos direitos fundamentais aplicáveis a imigrantes internacionais em situação de vulnerabilidade, alçando-os à condição de sujeitos de direito internacional, conforme Taiar (2009) e Trindade (2000). Representou ainda, a aplicação do Direito Internacional dos Direitos Humanos a casos concretos, com a incorporação formal dos tratados e pactos internacionais à nova lei migratória, adequando a legislação pátria ao sistema normativo global de proteção dos direitos humanos.

\section{CONSIDERAÇÕES FINAIS}

A crise econômica na Venezuela obrigou milhares de pessoas a cruzarem a fronteira para se refugiarem em Roraima. Os anos de 2014 a 2016 representaram o início do fluxo migratório, transformando rapidamente os municípios de Pacaraima/RR e algumas ruas da capital, Boa Vista, numa espécie de campo de refugiados a céu aberto. A ausência de programas sociais destinados aos imigrantes nos anos iniciais acabaram contribuindo para o agravamento da crise nos anos posteriores.

Interpretações ortodoxas da legislação por parte de agentes públicos, e a criminalização do ingresso de imigrantes, sem o cumprimento das formalidades legais no Brasil, também contribuíram para a crise e atrasaram o início das ações humanitárias. Inviabilizariam ainda as práticas de cuidado com os mais pobres, em especial em relação aos indígenas da etnia Warao, cujas peculiaridades demandavam a adoção de abordagens humanitárias urgentes e mais cuidadosas. A revogação de estatutos migratórios arcaicos e a adoção da interpretação lógico-sistemática dos pactos e convenções das quais o Brasil era signatário nas normas migratórias internas seria o primeiro passo para a mudança de orientação quanto ao auxílio humanitário ao povo venezuelano.

Embora tenha ratificado importantes tratados internacionais de direitos humanos, até 2016 o Brasil ainda não os havia efetivado. As melhorias implementadas nos anos seguintes parecem indicar o abandono de vetustas interpretações que insistiam em tentar justificar injustas políticas discriminatórias, sob o verniz da legalidade, e o reconhecimento da condição de que, de um modo ou de outro, todos somos migrantes. Esse artigo procurou atualizar o debate, avaliar a legitimidade de medidas implementadas no passado recente em relação venezuelanos em situação migratória, sob o duplo olhar da "legalidade estrita", e sob a luz do direito internacional dos direitos humanos. 
[1] BARAZAL, N. R. Yanomami: Um povo em luta pelos direitos Humanos. Editora da USP. São Paulo. 2013.

[2] BARRETO, H. G. Direitos indígenas vetores constitucionais. Editora Juruá.Curitiba, 2013.

[3] BRASIL, Planalto. Lei no 9.474, de 22 de julho de 1997. (Dispõe sobre os mecanismos para implementação do Estatuto dos Refugiados). Disponível em <http://www.planalto.gov.br/ccivil_03/Leis/L9474.htm> Acessado em: $25 / 01 / 2021$.

[4] BRASIL, Planalto. Lei no 6.815, de 19 de agosto de 1980. (Define a situação jurídica do estrangeiro no Brasil, cria o Conselho Nacional de Imigração). Disponível em <http://www.planalto.gov.br/ccivil_03/leis/L6815.htm> Acessado em: 25/01/2021.

[5] CANO, W. Venezuela: limites para uma nova política econômica. Economia e Sociedade. Campinas, v. 11, n. 1 (18), p. 95-127. 2002.

[6] COSTA, E. Pedidos de refúgio de venezuelanos em RR cresceram 22.000\% em 3 anos. 2017. Disponível em: http://g1.globo.com/rr/roraima/noticia/2017/03/pedidos-de-refugio-de-venezuelanos-em-rr-cresceram-22000-em3-anos.html. Acessado em: 10 fev. 2021.

[7] ENERO, D. R. Elementos para pensar reformas de la economía venezolana. Fundación Friedrich Ebert. 2016. Disponível em: <http://library.fes.de/pdf-files/bueros/caracas/12627.pdf > Acessado em: 25/01/2021.

[8] GERSEM, L. S. O índio Brasileiro: o que você precisa saber sobre os povos indígenas no Brasil de hoje. Ministério da Educação: LACED/Museu nacional. Brasília. 2006.

[9] HUMAN RIGHTS WATCH. O êxodo venezuelano: A necessidade de uma resposta regional a uma crise migratória sem precedentes. 2018. Disponível em: <https://www.hrw.org/pt/report/2018/09/03/322156>. Acessado em: 07/01/2021.

[10] ONU. Convenção Relativa ao Estatuto dos Refugiados das Nações Unidas, 1951. Disponível em: < http://www.acnur.org/t3/fileadmin/Documentos/portugues/BDL/Convencao_relativa_ao_Estatuto_dos_Refugiados. pdf> Acessado em 18/01/2021.

[11] PRAZERES, L. Crise faz pedidos de refúgio de venezuelanos no Brasil crescerem 1.036\% em 2 anos. UOL. 2016. Disponível em: <http://noticias.uol.com.br/internacional/ultimas-noticias/2016/02/26/crise-faz-pedidos-derefugio-de-venezuelanos-no-brasil-crescerem-1036-em-2-anos.htm> Acessado em: 27/01/2021.

[12] PUENTE, J. M. A economia venezuelana: situação atual e perspectivas no Mercosul. Cadernos Adenauer VIII (2007) nำ1.

[13] REAL, Amazônia. Crise na Venezuela: índios Warao fogem para o Brasil, mas são deportados pela PF. Amazônia Real. Manaus/AM, 13 jun. 2016. Disponível em https://amazoniareal.com.br/crise-na-venezuela-indioswarao-fogem-para-o-brasil-mas-sao-deportados-pela-pf/ Acessado em: 07/02/2021

[14] REUTERS. Inflação na Venezuela chega a 800\% e PIB recua quase 19\% em 2016. 2017. Disponível em: https://exame.com/economia/inflacao-na-venezuela-chega-a-800-e-pib-recua-quase-19-em-2016/. Acessado em: 10 fev. 2021.

[15] SANTOS, M. J. M. Crise econômica e migrações de venezuelanos para Roraima: um estudo sob a ótica dos direitos fundamentais da pessoa humana. Campo Grande/MS: Congresso Internacional de Direitos Humanos, 2016.

[16] SOUZA, A. O. Migração e Direitos Humanos: eficácia e legitimidade das medidas de proteção estatal adotadas na migração de venezuelanos para Roraima em 2016. 65 f. Monografia (Graduação) - Curso de Direito, Universidade Federal de Roraima, Boa Vista, 2016.

[17] SOUZA, J. \& GONZALO, C. Crise na Venezuela: índios Warao fogem para o Brasil, mas são deportados pela PF. Amazônia Real. 2016 Disponível em: <http://amazoniareal.com.br/crise-na-venezuela-indios-warao-fogem-para-obrasil-mas-sao-deportados-pela-pf/ > Acessado em 27/01/2021.

[18] TAIAR. R; Direito Internacional dos Direitos Humanos: Uma discussão sobre a relativização da soberania face à efetivação da proteção internacional dos direitos humanos. Tese Faculdade de Direito da Universidade de São Paulo. 2009.

[19] TRINDADE, A. A. C., A proteção internacional dos direitos humanos e o Brasil (1948-1997): as primeiras cinco décadas. BRASÍLIA, Editora Universidade de Brasília, 2000. 


\section{Capítulo 13}

Presunção de inocência versus liberdade de imprensa e seus reflexos na instituição do Júri

\section{Camila Fenalti Salla}

Resumo: 0 presente estudo busca investigar o reflexo da liberdade de imprensa sobre a garantia da presunção de inocência na instituição do Júri e na formação da convicção dos jurados. Para isso, empregou o método de abordagem dedutivo, métodos de procedimento histórico e tipológico e técnicas de pesquisa bibliográfica e documental. Averiguou a intensa e negativa interferência do pré-julgamento sensacionalista estabelecido pela mídia na formação da convicção dos jurados e o consequente prejuízo à garantia da presunção de inocência no rito do Tribunal do Júri. Verificou a necessidade de ponderação entre as garantias constitucionalmente asseguradas à liberdade de imprensa e à presunção de inocência com a finalidade de que o direito à presunção de inocência não continue a ter sua eficácia furtada pelo exercício desmedido da liberdade de imprensa pelas mídias nacionais.

Palavras-chave: liberdade de imprensa; presunção de inocência; tribunal do júri. 


\section{INTRODUÇÃO}

Nos tempos atuais, a discussão acerca de temas como as garantias penais versus liberdade de imprensa ganha tom especial. Isso se deve ao fato de que, com a difusão e popularização das novas mídias, o alcance das informações veiculadas nesses meios maximizou-se em escalas cada vez mais significativas. Com isso, surge uma nova realidade a ser enfrentada pela comunidade jurídica, ganhando relevo o natural e não raro embate entre as diversas garantias fundamentais asseguradas ao ser humano em nossa Carta Maior e a dúvida latente de qual deve sobressair no caso concreto.

Insere-se nessa discussão, com recorte na seara criminalista, o choque entre as garantias individuais do réu, mais especificamente a presunção de inocência, frente o direito à liberdade de imprensa e seus reflexos na instituição do Tribunal do Júri. Nesse sentido, busca-se averiguar qual o real impacto da liberdade de imprensa sobre a garantia da presunção da inocência na instituição do Júri e na formação da convicção dos jurados no julgamento de casos já noticiados pela mídia.

Para isso, como método de abordagem da temática em destaque utilizou-se a dedução, partindo-se do estudo dos direitos em confronto para a análise de seus reflexos sobre uma temática específica, no qual se procedeu de forma histórica e tipológica a partir de técnicas de pesquisa bibliográfica e documental. Nesse contexto, o presente estudo se estruturará primeiramente em uma análise dos direitos fundamentais em choque para então analisar o reflexo da liberdade de imprensa sobre a presunção de inocência no âmbito da formação da convicção dos jurados nas sessões de julgamento em sede de Tribunal do Júri.

\section{O PRINCÍPIO DA PRESUNÇÃO DE INOCÊNCIA}

O princípio da presunção de inocência pode ser traduzido na garantia que titulariza o réu de ser tido por inocente até o trânsito em julgado de sentença penal condenatória. Assegurado constitucionalmente na dicção do art. 50:

Todos são iguais perante a lei, sem distinção de qualquer natureza, garantindo-se aos brasileiros e aos estrangeiros residentes no País a inviolabilidade do direito à vida, à liberdade, à igualdade, à segurança e à propriedade, nos termos seguintes: [...] LVII - ninguém será considerado culpado até o trânsito em julgado de sentença penal condenatória; [...]. ${ }^{27}$

A Carta Maior de 1988 prevê a garantia indistinta a todos de ser considerado inocente pela prática de qualquer infração penal até que se prove o contrário. Isto é, por mais que existam provas no caso em apreço a indicar a culpabilidade do suposto autor do crime, não se pode estabelecer o rótulo de culpado antes de a decisão judicial ser definitivamente proferida de maneira irrecorrível.

Nesse mesmo sentido leciona o insigne mestre Aury Lopes Jr.:

Pode-se afirmar, com toda ênfase, que o princípio que primeiro impera no processo penal é o da proteção dos inocentes (débil), ou seja, o processo penal como direito protetor dos inocentes (e todos a ele submetidos o são, pois só perdem esse status após a sentença condenatória transitar em julgado), pois esse é o dever que emerge da presunção constitucional de inocência prevista no art. 5o, LVII, da Constituição. ${ }^{28}$

Sua origem remonta ao Direito Romano. Desde então, a preocupação em assegurar uma condição digna ao homem no deslinde de um rito acusatório podia ser verificado. Nos tempos antigos, essa angústia em conferir o direito à presunção de inocência tinha sua expressão "nos escritos de Trajano [...] “É melhor ser considerado ruim do que culpar um inocente."'”. 29

Infelizmente, nos tempos inquisitoriais experimentados ao longo da Idade Média, esta garantia perdeu suas forças, tendo sido resgatada com veemência apenas no século XVIII com chegada da Revolução

\footnotetext{
${ }^{27}$ BRASIL. Constituição Federal. Brasília: Senado $1988 . \quad$ Dederal, <http://www.planalto.gov.br/ccivil_03/constituicao/constituicaocompilado.htm>. Acesso em: 16 set. 2017.

${ }^{28}$ LOPES JR., Aury. Fundamentos do Processo Penal: Introdução Crítica. São Paulo: Saraiva, 2017. p. 35.

${ }^{29}$ VIANNA, Felipe Augusto Fonseca. Presunção de Inocência e Liberdade de Imprensa: A Cobertura Midiática e sua Influência no Tribunal do Júri. Estudo em Homenagem ao Professor Nasser Abrahim Nasser Netto. Conteúdo Jurídico, Brasilia-DF: 19 maio 2015. Disponivel em: <http://www.conteudojuridico.com.br/?artigos\&ver=2.53468\&seo=1>. Acesso em: 16 set. 2017.
} 
Francesa e dos ideais iluministas, ocasião em que foi positivada na Declaração de Direitos do Homem e do Cidadão, a qual passou a prever que: "art. 9ō: Todo acusado é considerado inocente até ser declarado culpado e, caso eja considerado indispensável prendê-lo, todo rigor desnecessário à guarda da sua pessoa deverá ser severamente reprimido pela lei.". ${ }^{30}$

Afortunadamente, na atualidade a presunção de inocência passou a ser protagonista dentro dos diplomas reguladores nacionais e internacionais, a exemplo da Declaração Universal dos Direitos do Homem de 1948, pós Segunda Grande Guerra, e a Constituição Federal da República Federativa do Brasil de 1988.

Após as conquistas históricas de positivação desta garantia e a consequente presença permanente do direito à presunção de inocência nas cartas que regulamentam a vida em sociedade, passou-se a perquirir a sua real aplicabilidade e eficácia quando em confronto com outras garantias fundamentais constitucionalmente asseguradas e que podem acabar por macular a sua esperada carga de eficácia, a exemplo da colisão dos direitos liberdade de imprensa e presunção de inocência ora em análise. Neste estudo investiga-se os possíveis reflexos da liberdade de imprensa quando em confronto com a presunção de inocência no rito do Júri, e, para isso, analisaremos no tópico seguinte como a garantia da presunção de inocência se manifesta no procedimento do Tribunal do Júri.

\subsection{A PRESUNÇÃO DE INOCÊNCIA NO RITO DO TRIBUNAL DO JÚRI}

0 Tribunal do Júri é instituição também assegurada constitucionalmente no vocábulo do art. 5ํ:

Todos são iguais perante a lei, sem distinção de qualquer natureza, garantindo-se aos brasileiros e aos estrangeiros residentes no País a inviolabilidade do direito à vida, à liberdade, à igualdade, à segurança e à propriedade, nos termos seguintes: [...] XXXVIII - é reconhecida a instituição do júri, com a organização que lhe der a lei, assegurados: a) a plenitude de defesa; b) o sigilo das votações; c) a soberania dos veredictos; d) a competência para o julgamento dos crimes dolosos contra a vida; $\left[. . . .^{31}\right.$

O constituinte originário garantiu que os acusados de terem cometido crimes dolosos contra a vida serão julgados por seus pares. Nesse caminhar, a decisão absolutória ou condenatória será conferida através do veredito de cidadãos comuns que comporão a bancada de jurados. Ainda, salientou a importância da plenitude de defesa em sede de Júri, tendo o contraditório e a ampla defesa ganhado relevo especial.

No que tange ao rito da instituição do Júri, o diploma processualista penal disciplina a matéria trazendo notável relevância ao princípio da presunção da inocência em diversas passagens, como será pormenorizadamente exemplificado.

Numa primeira expressão, dispõe o Código de Processo Penal no capítulo atinente ao procedimento relativo aos processos de competência do Tribunal do Júri em seu art. 413, §1ํ que "A fundamentação da pronúncia limitar-se-á à indicação da materialidade do fato e da existência de indícios suficientes de autoria ou de participação, [...].".32

Esse dispositivo consagra o que a doutrina costuma chamar de vedação à eloquência acusatória do juiz singular na decisão de pronúncia, instituto que foi explicitado com brilhantismo em julgamento de habeas corpus pelo Supremo Tribunal Federal, senão vejamos:

A decisão de pronúncia deve ser sucinta, exatamente para evitar que a apreciação exaustiva do "thema decidendum" culmine por influenciar os próprios integrantes do Conselho de Sentença, que são os juízes naturais dos réus acusados e pronunciados por crimes dolosos contra a vida. [...] 0 juízo de delibação subjacente à decisão de pronúncia impõe limitações jurídicas à

${ }^{30}$ DECLARAÇÃo de direitos do homem e do cidadão - 1789. Biblioteca Virtual de Direitos Humanos. Disponível em: <http://www.direitoshumanos.usp.br/index.php/Documentos-anteriores-\%C3\%A0-cria\%C3\%A7\%C3\%A3o-da-Sociedade-dasNa\%C3\%A7\%C3\%B5es-at\%C3\%A9-1919/declaracao-de-direitos-do-homem-e-do-cidadao-1789.html>. Acesso em: 16 set. 2017.

${ }^{31}$ BRASIL. Constituição Federal. Brasília: Senado Federal, $1988 . \quad$ Disponível em: <http://www.planalto.gov.br/ccivil_03/constituicao/constituicaocompilado.htm>. Acesso em: 16 set. 2017.

32 BRASIL. Código de Processo Penal. Decreto-Lei no 3.689, de 03 de outubro de 1941. Disponível em: <http://www.planalto.gov.br/ccivil_03/decreto-lei/Del3689Compilado.htm>. Acesso em: 16 set. 2017. 
atividade processual do órgão judiciário de que emana, pois este não poderá sob pena de ofender o postulado da igualdade das partes e de usurpar a competência do Tribunal do Júri - analisar, com profundidade, o mérito da causa nem proceder à apreciação crítica e valorativa das provas colhidas ao longo da persecução penal. Inexistência de eloquência acusatória no conteúdo da decisão de pronúncia impugnada, que não antecipou qualquer juízo desfavorável ao paciente, apto a influir, de maneira indevida, sobre o ânimo dos jurados. ${ }^{33}$

Num segundo momento, agora propriamente no procedimento da sessão plenária de julgamento do Júri, a presunção de inocência tem nítida expressão na vedação imposta à acusação, sob pena de nulidade, de durante os debates fazer referências à decisão de pronúncia, às decisões posteriores que julgaram admissível a acusação ou à determinação do uso de algemas como argumento de autoridade que prejudiquem o acusado. ${ }^{34}$

Destarte, percebe-se o nítido cuidado do legislador ordinário em assegurar plena eficácia ao princípio da presunção de inocência dentro da instituição do Tribunal do Júri, o que foi feito através da previsão de diversos dispositivos legais, que, quando violados, podem levar à nulidade do julgamento.

Passa-se, agora, à análise do direito à liberdade de imprensa para, posteriormente, poder-se analisar o impacto da informação veiculada na mídia em matéria de inquéritos policiais e ações penais em curso e sua influência nos julgamentos das sessões plenárias do Tribunal do Júri, mais especificamente no que tange à formação da convicção dos jurados e o pré-julgamento estabelecido pela cobertura midiática.

\section{0 DIREITO À LIBERDADE DE IMPRENSA}

Outro direito constitucionalmente assegurado e definido como direito fundamental, que merece especial proteção do Estado, é a liberdade de expressão ou liberdade de pensamento, a qual pode ser traduzida no direito de expressar-se ou no direito de emitirem-se opiniões, sendo amplamente reconhecido que essa liberdade constitui um dos direitos fundamentais mais preciosos e corresponde a uma das mais antigas exigências humanas..$^{35}$

Suas primeiras aparições enquanto direito assegurado constitucionalmente remontam a tempos longínquos, pois é certo que "desde o advento do constitucionalismo, a maior parte das constituições dos países democráticos assegura a liberdade de expressão e a liberdade de imprensa". ${ }^{36}$

A Carta Maior assegura essa garantia fundamental em diversas passagens, a ver: dispõe o art. 5o , inciso IV da Constituição da República Federativa do Brasil que "é livre a manifestação do pensamento sendo vedado o anonimato". ${ }^{37}$ Ainda, no mesmo artigo passa a prever em seu inciso IX que "é livre a expressão da atividade intelectual, artística, científica e de comunicação, independentemente de censura ou licença". ${ }^{38}$

Não menos importante é a previsão do art. 220 do mesmo diploma maior ao estatuir que "A manifestação do pensamento, a criação, a expressão e a informação, sob qualquer forma, processo ou veículo não sofrerão qualquer restrição, observado o disposto nesta Constituição.". ${ }^{39}$ Esse último dispositivo

${ }^{33}$ BRASIL. Supremo Tribunal Federal. Habeas corpus impetrado contra decisão do Superior Tribunal de Justiça que rechaça a nulidade por excesso de linguagem de sentença de pronúncia. HC 113091. Superior Tribunal de Justiça e Décio José Barroso Nunes. Relator: Ministro Celso de Mello. 12 de novembro de 2013. Disponível em: https://stf.jusbrasil.com.br/jurisprudencia/24664386/habeas-corpus-hc-113091-pa-stf/inteiro-teor-112144943?ref=juristabs>. Acesso em: 16 set. 2017.

34 BRASIL. Código de Processo Penal. Decreto-Lei no 3.689, de 03 de outubro de 1941 . Disponível em: <http://www.planalto.gov.br/ccivil_03/decreto-lei/Del3689Compilado.htm>. Acesso em: 16 set. 2017.

${ }^{35}$ SARLET, Ingo Wolfgang; MITIDIERO, Daniel; MARINONI, Luiz Guilherme. Curso de Direito Constitucional. São Paulo: Saraiva, 2017. p. 495.

${ }^{36}$ CANOTILHO, José Joaquim Gomes; MENDES, Gilmar Ferreira; SARLET, Ingo Wolfgang; STRECK, Lenio Luiz. Comentários à Constituição do Brasil. São Paulo: Saraiva, 2013. p. 2034.

37 BRASIL. Constituição Federal. Brasília: Senado Federal, $1988 . \quad$ Disponível em: <http://www.planalto.gov.br/ccivil_03/constituicao/constituicaocompilado.htm>. Acesso em: 16 set. 2017.

\footnotetext{
${ }^{38}$ Ibidem.
}

${ }^{39}$ Ibidem. 
constitucional consagra a liberdade de imprensa, que está diretamente associada à liberdade de expressão.

Feitas essas considerações, "resta bem claro, da leitura de tais dispositivos, que a proteção constitucional à liberdade de imprensa existe no intuito de impedir que o Estado cerceie ou dificulte a circulação e o acesso às informações [...].”. .40

Não obstante, nesse contexto surge o importante e necessário questionamento do qual pode se extrair a seguinte pergunta: até que ponto a imprensa está autorizada a veicular informações de inquéritos policiais ou mesmo ações penais ainda em curso com a divulgação da suposta autoria do crime frente ao direito da presunção de inocência do réu até o trânsito em julgado da decisão penal condenatória?

Essa questão já foi amplamente debatida nos tribunais pátrios superiores e hoje encontra a seguinte resposta: as mídias, no exercício da sua liberdade de imprensa, estão autorizadas a veicular informações nos meios de comunicação e publicar matérias jornalísticas que contenham informações sobre situações ainda em fase investigativa desde que com fulcro em informações estritamente fidedignas.

De toda sorte, resta ainda dúvida acerca da legitimidade da influência que o exercício da liberdade de imprensa, muitas vezes fora dos parâmetros autorizados, pode imprimir na formação da convicção do Conselho de Sentença, tendo em vista que os jurados já vêm à sessão de julgamento com uma bagagem de informações recebidas pelos veículos midiáticos.

Essa discussão ganha relevo na medida em que se tem conhecimento de que as matérias jornalísticas e criminais que são veiculadas nas mídias nacionais ganham importante carga sensacionalista e estabelecem pré-julgamentos velados, uma vez que "o jornalista define qual o ângulo será privilegiado na notícia"41, com maior impacto ainda quando diante da gravidade existente nos crimes que são submetidos a julgamento pelo rito do Tribunal do Júri. Nesse sentido,

A atuação da mídia é questionável [...], pois, [...] a maneira sensacionalista como ataca o suspeito, em rede nacional, o apontando como culpado, ultrapassa o campo da presunção. Dessa forma, a mídia considera culpado até que se prove o contrário, desrespeitando o princípio constitucional da presunção de inocência. 42

Passa-se, portanto, no capítulo seguinte, à análise desta importante questão, estudo central do presente trabalho.

\section{O REFLEXO DA LIBERDADE DE IMPRENSA SOBRE A PRESUNÇÃO DE INOCÊNCIA NO TRIBUNAL DO JÚRI}

Feitas as devidas análises da essência dos direitos fundamentais em colisão, passa-se ao estudo do reflexo imprimido pela liberdade de imprensa (liberdade à informação jornalística) sobre a presunção de inocência do réu que será julgado pelos juízes naturais do rito do Júri, mais especificamente no que diz respeito à interferência na formação da convicção dos jurados.

Por oportuno, resta consignar que jurados serão aqueles escolhidos entre cidadãos comuns, dispondo o Código de Processo Penal que: "O serviço do júri é obrigatório. 0 alistamento compreenderá os cidadãos maiores de 18 (dezoito) anos de notória idoneidade." ${ }^{43}$ Ainda, em clara tentativa de evitar o préjulgamento dos jurados a compor o Conselho de Sentença, determina o diploma processualista penal que o jurado que manifestar prévia disposição a condenar ou absolver o acusado não poderá servir a essa função naquele julgamento. ${ }^{44}$

\footnotetext{
${ }^{40}$ VIANNA, op. cit.

${ }^{41}$ BUDÓ, Marília Denardin. Mídia e crime: a contribuição do jornalismo para a legitimação do sistema penal. UNIrevista, Florianópolis, n. 3, jul. 2006. p. 8.

${ }^{42}$ FERREIRA, Michelle Kalil. O Princípio da Presunção de Inocência e a exploração Midiática. Revista Jurídica do Ministério Público do Estado de Minas Gerais. Belo Horizonte, n. 9, jul./dez. 2007. p. 66.

43 BRASIL. Código de Processo Penal. Decreto-Lei no 3.689, de 03 de outubro de 1941. Disponível em: <http://www.planalto.gov.br/ccivil_03/decreto-lei/Del3689Compilado.htm>. Acesso em: 16 set. 2017.

44 Ibidem.
} 
Ou seja, a lei processual penal determina uma série de restrições legais àquele que irá exercer a função de jurado justamente na tentativa de evitar um pré-julgamento por parte de quem irá condenar ou absolver o cidadão que ocupa o banco dos réus, a fim de se alcançar escopo da imparcialidade e da livre convicção de cada jurado, para que assim exista um julgamento justo e livre e se atenda o pressuposto da plenitude de defesa disposto na Carta Magna de 1988.

O desígnio na instituição do Tribunal do Júri é justamente que cada jurado que passa a compor o Conselho de Sentença julgue de forma livre e desimpedida aquele que ocupa o assento dos réus, a partir de seus valores e principalmente com a conviç̧ão formada a partir das teses trazidas pela acusação e defesa em sede de debates, para que assim se alcance a mais límpida justiça.

Ocorre que, uma vez ocorrida a ampla difusão das mídias na atualidade e, por conseguinte, o descomunal alcance das informações que nelas são veiculadas, aquele que exerce a função de jurado e passa a compor o Conselho de Sentença certa e inevitavelmente faz parte do grande público alvo da imprensa nacional. Particularmente preocupante, neste ponto, a publicidade prévia pelos meios de comunicação do fato criminoso e seu desenvolvimento processual perante o Tribunal do Júri. ${ }^{45}$

Isso porque, o julgamento é feito por juízes leigos e a impressão que a mídia transmite do crime e do criminoso produz maior efeito neles do que as reais provas trazidas pelas partes na instrução e julgamento no plenário.". ${ }^{46}$ Além de que, é de conhecimento de todos o fato de que

o jurado é mais suscetível à opinião pública e à comoção que se criou em torno do caso em julgamento, do que os juízes togados e, por se sentirem pressionados pela campanha publicitária, correm o risco de se afastarem do dever da imparcialidade, acabando por julgar de acordo com o que foi transmitido na mídia. ${ }^{47}$

Nesse sentido, a imprensa, através do seu direito à veiculação da informação jornalística, tem por praxe fazer a cobertura de situações crime, principalmente quando afetas a crimes da competência do Júri Popular. Não obstante, tristemente, na grande maioria das vezes a imprensa não exerce o seu direito à liberdade de informação jornalística nos limites em que lhe é conferida, isto é, com base em infromações estritamente fidedignas, mas sim, acaba por veicular matérias calcadas em meras especulações e suspeitas. Ou seja, a fidedignidade reclamada pelo Superior Tribunal de Justiça não é atendida.

Isso resulta em uma situação na qual o cidadão que chega até o banco de jurado já terá recebido uma carga de prévias informações acerca do caso em apreço, muitas vezes não fidedignas e lastreadas por um intenso tom sensacionalista, o que, por óbvio, irá impedir a formação de uma livre e desimpedida convicção em sede de julgamento, e isso porque "a divulgação de determinada notícia veiculada com um teor sensacionalista tende a influenciar de forma manipulada o telespectador sobre o tema em pauta.". ${ }^{48}$ Nos dizeres de José Armando da Costa Júnior,

Possuidora do direito à liberdade de imprensa, a mídia ultrapassa seus limites quando deixa de cumprir a sua função de informar e passa a criar informações levianas, formadoras de opiniões. Essas informações falsas geram no consciente do jurado uma realidade distorcida do que de fato aconteceu, criando uma imagem negativa do acusado. 49

\footnotetext{
${ }^{45}$ CAMPOS, Marco Antonio Magalhães de. A influência da mídia no Processo Penal. 2012. Trabalho de Conclusão de Curso (Curso de Pós-Graduação Lato Sensu da Escola de Magistratura do Estado do Rio de Janeiro) - Escola de Magistratura do Estado do Rio de Janeiro, Rio de Janeiro, $\quad$ RJ, $2012 . \quad$ Disponível $\quad$ em: <http://www.emerj.tjrj.jus.br/paginas/trabalhos_conclusao/1semestre2012/trabalhos_12012/marcoantoniocampos.pdf>. Acesso em: 16 set. 2017. p. 12.

${ }^{46}$ CAMPOS, op. cit. p. 12.

47 Ibidem.

48 ANDRADE, Fábio Martins de. Mídia e Poder Judiciário: A Influência dos órgãos da mídia no processo penal brasileiro. Rio de Janeiro: Lumen Juris, 2007, p. 251.

${ }^{49}$ COSTA JÚNIOR, José Armando da. 0 Tribunal do Júri e a efetivação de seus princípios constitucionais. 2007. 107 f. Dissertação (Mestrado em Direito Constitucional) - Programa de Pós Graduação do Centro de Ciências Jurídicas, Universidade de Fortaleza, Fortaleza, 2007. Disponível em: <http://dominiopublico.mec.gov.br/download/teste/arqs/cp049129.pdf>. Acesso em: 16 set. 2017.
} 
Ocorre que é inaceitável que "os jurados já estejam com a opinião formada antes mesmo de conhecer detalhadamente o processo". ${ }^{50}$ Essa situação, que vem ocorrendo, de forma clara fere o direito à presunção de inocência. 0 jurado, que teria por dever julgar a partir da construção de sua livre convicção (através das exposições da defesa e acusação) inevitavelmente o fará também - se não somente - em razão das exposições sensacionalistas da imprensa, pois já inconscientemente imbuído de um pré-julgamento estabelecido por ela. Assim, veja-se que não há espaço à presunção de inocência. "Isso porque não se pode garantir o princípio da presunção de inocência ao réu ao mesmo tempo em que a mídia de forma obstinada divulga negativamente o fato.".51

Ainda, veja-se, a veiculação de informação mesmo quando fidedigna é carregada por um tom sensacionalista que, inevitavelmente, estabelece um julgamento antecipado daquele que é o suposto autor do delito, o que acaba por também prejudicar o livre exercício da plenitude de defesa e a presunção de inocência que deveria imperar até o final dos julgamentos criminais. E isso se deve ao fato de que os jurados

já chegam ao julgamento com a opinião formada e a pressão popular e as excessivas reportagens em favor de uma condenação são razões suficientes para impedir que os jurados decidam de forma livre sobre o veredicto. ${ }^{52}$

Destarte, diante da percepção da realidade que se impõe pela mídia de uma verdadeira formação prévia de opinião e de real interferência na livre convicção dos jurados,

a violação ao princípio da presunção da inocência pela influência exercida pela mídia também se mostra de fácil observação, na medida em que as acusações levianas feitas pelos órgãos da imprensa fazem com que o réu já inicie o seu julgamento condenado pelo clamor social..$^{53}$

Assim sendo, a liberdade de imprensa conferida às mídias no Brasil acaba por, na grande maioria das vezes, ser exercida de maneira que ultrapassa as limitadoras da fidedignidade impostas ao seu exercício e, assim, põe em cheque o elogiável esforço do legislador em conferir a mais tranquila imparcialidade ao Conselho de Sentença.

\section{CONCLUSÃO}

Não restam dúvidas de que a Constituição Cidadã estabeleceu diversas garantias fundamentais à pessoa, dentre as quais a presunção de inocência, a qual garante que ninguém será considerado culpado senão em razão do trânsito em julgado de sentença penal condenatória, bem como a liberdade de expressão e de imprensa, que vêm a garantir, respectivamnte, a livre manifestação de pensamento, bem como assegurar que a criação, a expressão e a informação não sofrerão qualquer espécie de restrição.

A Magna Carta de 1988 estabeleceu ainda a garantia da instituição do Tribunal do Júri e os princípios que devem regular o seu funcionamento, sendo a plenitude de defesa e a soberania dos vereditos dois de seus princípios norteadores. 0 diploma processualista penal ainda impôs uma série de vedações àqueles que comporão o Conselho de Sentença, dentre os quais está a impossibilidade de exercer a função de jurado aquele que manifestar prévia disposição a condenar ou absolver o acusado.

Ora, diante destas premissas resta cristalino que todas são garantias invioláveis e que devem ser concomitantemente asseguradas ao cidadão, no sentido de que nenhuma poderá se sobrepor furtando a eficácia de outra. Não obstante, a partir do exposto pôde-se perceber que o contrário vem ocorrendo. 0 pré-julgamento estabelecido pela mídia acaba por furtar a eficácia da vedação ao exercício da função de jurado daquele que manifesta prévia disposição a condenar ou absolver o acusado, e, consequentemente, macula a plenitude de defesa do réu, bem como a presunção da sua inocência.

\footnotetext{
${ }^{50}$ SOUSA, Iane Andrade. A influência da mídia no tribunal do júri: A influência da mídia no tribunal do júri frente à presunção de inocência e à dignidade da pessoa humana. 2015. Trabalho de Conclusão de Curso (Curso de Graduação em Direito) Universidade $\quad$ Tiradentes $\quad$ - $\quad$ UNIT, $\quad$ Aracajú, $2015 . \quad$ Disponível em: <http://openrit.grupotiradentes.com/xmlui/bitstream/handle/set/1213/Artigo\%20Iane.pdf?sequence=1>. Acesso em: 16 set. 2017. p. 1.

${ }^{51}$ COSTA JÚNIOR, op. cit. p. 92.

52 Ibidem. p. 90.

${ }^{53}$ CAMPOS, op. cit. p. 12.
} 
Infelizmente, o pré-julgamento e o sensacionalismo veiculados através das mídias sociais retiram do cidadão a capacidade de deliberar de forma livre e de formar seu convencimento desimpedido quando na função de jurado, e isso se deve a um resultado involuntário gerado pelo irregular exercício do direito à liberdade de imprensa, que faz com que as garantias da presunção de inocência do acusado e sua plenitude de defesa restem prejudicadas. Ou seja, constatou-se um reflexo extremamente negativo que vem sendo gerado pelo irregular exercício da liberdade de imprensa sobre a garantia da presunção de inocência na instituição do Júri e na formação da convicção dos jurados.

Nesse sentido, faz-se mister uma análise e reflexão acerca do necessário sopesamento que deve ser estabelecido entre as garantias da liberdade de imprensa e da presunção de inocência, principalmente dentro da realidade do Tribunal do Júri, com a finalidade de que o direito à presunção de inocência não continue a ter sua eficácia furtada pelo exercício desmedido da liberdade de imprensa pelas mídias nacionais.

\section{REFERÊNCIAS}

[1]. ANDRADE, Fábio Martins de. Mídia e Poder Judiciário: A Influência dos órgãos da mídia no processo penal brasileiro. Rio de Janeiro: Lumen Juris, 2007.

[2]. BRASIL. Código de Processo Penal. Decreto-Lei no 3.689, de 03 de outubro de 1941. Disponível em: <http://www.planalto.gov.br/ccivil_03/decreto-lei/Del3689Compilado.htm>. Acesso em: 02 set. 2017.

[3]. _. Constituição Federal. Brasília: Senado Federal, $1988 . \quad$ Disponível em: <http://www.planalto.gov.br/ccivil_03/constituicao/constituicaocompilado.htm>. Acesso em: 02 set. 2017.

[4]. __ _ Supremo Tribunal Federal. Habeas corpus impetrado contra decisão do Superior Tribunal de Justiça que rechaça a nulidade por excesso de linguagem de sentença de pronúncia. HC 113091. Superior Tribunal de Justiça e Décio José Barroso Nunes. Relator: Ministro Celso de Mello. 12 de novembro de 2013. Disponível em: <https://stf.jusbrasil.com.br/jurisprudencia/24664386/habeas-corpus-hc-113091-pa-stf/inteiro-teor112144943?ref=juris-tabs>. Acesso em: 05 set. 2017.

[5]. BUDÓ, Marília Denardin. Mídia e crime: a contribuição do jornalismo para a legitimação do sistema penal. UNIrevista, Florianópolis, n. 3, jul. 2006.

[6]. CAMPOS, Marco Antonio Magalhães de. A influência da mídia no Processo Penal. 2012. Trabalho de Conclusão de Curso (Curso de Pós-Graduação Lato Sensu da Escola de Magistratura do Estado do Rio de Janeiro) Escola de Magistratura do Estado do Rio de Janeiro, Rio de Janeiro, RJ, 2012. Disponível em: <http://www.emerj.tjrj.jus.br/paginas/trabalhos_conclusao/1semestre2012/trabalhos_12012/marcoantoniocampos .pdf>. Acesso em: 14 set. 2017.

[7]. CANOTILHO, José Joaquim Gomes; MENDES, Gilmar Ferreira; SARLET, Ingo Wolfgang; STRECK, Lenio Luiz. Comentários à Constituição do Brasil. São Paulo: Saraiva, 2013.

[8]. COSTA JÚNIOR, José Armando da. O Tribunal do Júri e a efetivação de seus princípios constitucionais. 2007. 107 f. Dissertação (Mestrado em Direito Constitucional) - Programa de Pós Graduação do Centro de Ciências Jurídicas, Universidade de Fortaleza, Fortaleza, $2007 . \quad$ Disponível em: <http://dominiopublico.mec.gov.br/download/teste/arqs/cp049129.pdf>. Acesso em: 10 set. 2017.

[9]. DECLARAÇÃO de direitos do homem e do cidadão - 1789. Biblioteca Virtual de Direitos Humanos. Disponível em: <http://www.direitoshumanos.usp.br/index.php/Documentos-anteriores-\%C3\%A0-cria\%C3\%A7\%C3\%A3o-daSociedade-das-Na\%C3\%A7\%C3\%B5es-at\%C3\%A9-1919/declaracao-de-direitos-do-homem-e-do-cidadao1789.html> Acesso em: 16 set. 2017.

[10]. FERREIRA, Michelle Kalil. O Princípio da Presunção de Inocência e a exploração Midiática. Revista Jurídica do Ministério Público do Estado de Minas Gerais. Belo Horizonte, n. 9, jul./dez. 2007.

[11]. LOPES JR., Aury. Fundamentos do Processo Penal: Introdução Crítica. São Paulo: Saraiva, 2017.

[12]. SARLET, Ingo Wolfgang; MITIDIERO, Daniel; MARINONI, Luiz Guilherme. Curso de Direito Constitucional. São Paulo: Saraiva, 2017.

[13]. SOUSA, Iane Andrade. A influência da mídia no tribunal do júri: A influência da mídia no tribunal do júri frente à presunção de inocência e à dignidade da pessoa humana. 2015. Trabalho de Conclusão de Curso (Curso de Graduação em Direito) - Universidade Tiradentes - UNIT, Aracajú, 2015. Disponível em: <http://openrit.grupotiradentes.com/xmlui/bitstream/handle/set/1213/Artigo\%20Iane.pdf?sequence=1>. Acesso em: 10 set. 2017.

[14]. VIANNA, Felipe Augusto Fonseca. Presunção de Inocência e Liberdade de Imprensa: A Cobertura Midiática e sua Influência no Tribunal do Júri. Estudo em Homenagem ao Professor Nasser Abrahim Nasser Netto. Conteúdo Jurídico, $\quad$ Brasilia $\quad-\quad$ DF: $19 \quad$ maio $2015 . \quad$ Disponível <http://www.conteudojuridico.com.br/?artigos\&ver=2.53468\&seo=1 >. Acesso em: 05 set. 2017. 


\section{Capítulo 14}

\section{Conflito e Paixão: Três momentos da história em que o futebol foi mais que um jogo}

\section{David de Brito Alvarenga}

João Paulo Ferreira

Samuel de Gois Vida

Resumo: 0 presente trabalho tem como principal objetivo a divulgação do conhecimento histórico, com vistas à popularização da disciplina, cujo objetivo específico é apresentar três momentos históricos em que o futebol figurou como ator político de primeira ordem: nos períodos da Primeira e Segunda Guerras Mundial e na Ditadura da Argentina. Nesse sentido, prima pelo texto em formato jornalístico.

Na Primeira Guerra (1914 - 1918), durante a Trégua de Natal, soldados alemães e ingleses deixaram as trincheiras e entoavam cantos natalinos para comemorar a data, durante seis dias os rivais jogavam, trocavam presentes e abraços. Já na Segunda Guerra Mundial (1939 - 1945), um grupo de poloneses foram obrigados a jogar contra os nazistas, por fim, foram presos, torturados e quatro deles assassinados. Por fim, na Ditadura Argentina (1976 - 1983), sob o regime de Videla, grupos opositores organizaram um boicote à realização da Copa do Mundo, no ano de 1978. Com fotografias, documentos e correspondências, denunciavam ao mundo e a Argentina os mal-feitos por detrás dos jogos de futebol.

Esses casos apresentam o futebol como elemento social e político importante para a história recente do mundo.

Palavras-chave: Futebol e Política; História do futebol; História política. 


\section{INTRODUÇÃO}

O futebol é algo apaixonante para diversas nações, inclusive o Brasil. Povos que se identificam com o esporte tornando-o muito mais do que um lazer. De fato, também, tal esporte passou por momentos não muito alegres em sua história. Momentos que se eternizaram na história, deixaram lições e aprendizagens para toda a humanidade.

De acordo com Hollanda (2014), o futebol é objeto de estudo de diversas áreas do conhecimento, pois apresenta um desafio compreensivo e explicativo mobilizando "os mais diferentes ângulos de análise culturais, políticos, sociais, econômicos e até psicológicos - a fim de dar conta da latitude e da longitude do fenômeno." (HOLLANDA, 2014. p.2).

Nota-se que o futebol se transformou, se idealizou e se modificou em simbiose com a sociedade como um todo, principalmente quando se fala de Europa, pois se um dia o futebol foi algo relacionado apenas na diversão dos praticantes, hoje percebe-se o grande avanço deste esporte como um gigantesco meio econômico e social. De acordo com Café (2010), A FIFA tem mais membros que a ONU, e sua importância no cenário político é crescente desde a primeira metade do século XX, quando foi largamente utilizado como peça de propaganda pelo nazifascismo ${ }^{54}$.

0 presente trabalho é fruto de uma atividade transdisciplinar desenvolvida no primeiro semestre do curso de Licenciatura em História do Campus Inconfidentes. Trata-se, portanto, de um trabalho de divulgação do conhecimento histórico, com vistas à popularização da disciplina e cujo objetivo específico é apresentar três momentos históricos em que o futebol figurou como ator político de primeira ordem. Nesse sentido, prima pelo texto em formato jornalístico.

\section{MATERIAL E MÉTODOS}

O trabalho consiste em um levantamento bibliográfico e informacional acerca de três eventos históricos em que o futebol figurou com destaque no contexto político internacional: nos períodos da Primeira e Segunda Guerras Mundial e na Ditadura da Argentina. A maioria das fontes é jornalística, de reportagens especiais sobre a temática, bem como de artigos de revistas de divulgação histórica.

Na Primeira Guerra (1914-1918), durante a Trégua de Natal, soldados alemães e ingleses deixaram as trincheiras e entoavam cantos natalinos para comemorar a data, durante seis dias rivais jogavam, trocavam presentes e abraços. Já na Segunda Guerra Mundial (1939 - 1945), um grupo de poloneses foram obrigados a jogar contra os nazistas, por fim, foram presos, torturados e quatro deles assassinados. Por fim, na Ditadura Argentina (1976 - 1983), sob o regime de Videla, grupos opositores organizaram um boicote à realização da Copa do Mundo, no ano de 1978.

\section{RESULTADOS E DISCUSSÕES}

As pesquisas bibliográficas e jornalísticas propiciaram a construção de breves narrativas acerca das temáticas escolhidas. 0 resultado é a análise de três eventos históricos em que o futebol foi muito mais que um jogo. Nas duas Grandes Guerras, seu papel se destacou como unificador na Primeira, e motivo de ódio na Segunda. De acordo com Pinto (2019):

Durante seis dias houve um cessar-fogo .Entretanto, não foi apenas durante o natal de 1914 que houve confraternização entre soldados de países em conflito durante a I Guerra Mundial. Mesmo com as proibições dos oficiais, deserções e confraternizações entre soldados de diferentes nacionalidades continuaram a ocorrer, sendo essas ocorrências também umas das causas que levaram. (PINTO, 2019, p 01.).

O espírito natalino suscitou o jogo, que foi disputado com espírito de amizade e de lazer em meio ao caos. A trégua natalina durante a Primeira Grande Guerra é um forte e conhecido fato que, através do futebol e

${ }^{54}$ Para saber mais acesse: https://educacao.uol.com.br/disciplinas/historia/futebol-e-nazi-fascismo-esporte-serviu-propaganda-demussolini-e-hitler.htm Acesso em: 12.set.2019 
da importância do natal tanto para alemães quanto para ingleses, destruiu inimizades, quebrou paradigmas e trouxe lazer para um povo que vivia em meio a um dos piores conflitos de toda a humanidade.

Imagem 1: Fotografia de soldados rivais durante a trégua de Natal, em 1914.

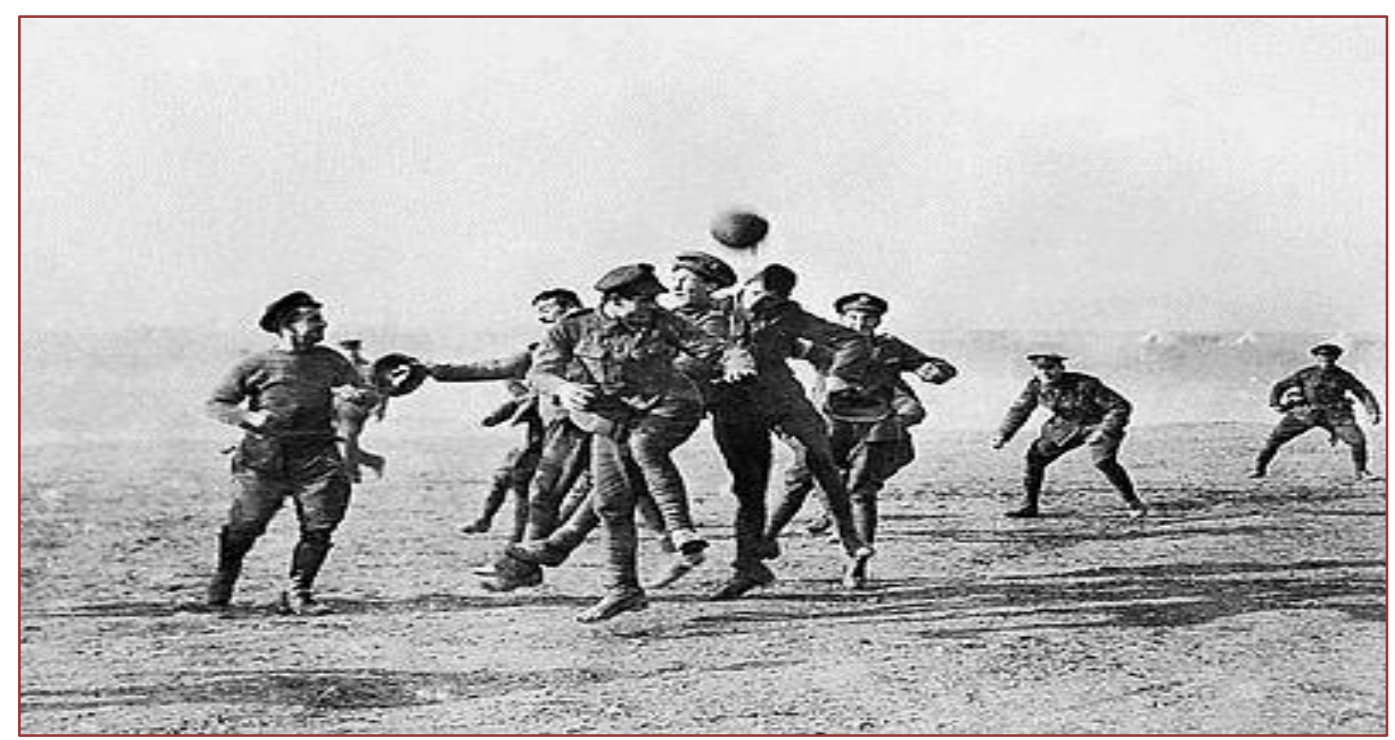

No dia 9 de agosto de 1942 foi realizada uma partida de futebol em Kiev, entre um time alemão, (Flakelf) e um time ucraniano, o (Start). Nada de anormal se Ucrânia não estivesse sob domínio nazista desde setembro de 1941. Após uma partida marcada pela violência e arbitragem tendenciosa, a vitória dos ucranianos por 5 a 3, em cima do Flakelf, formado por pilotos da força aérea nazista (Luftwaffe) teve grande repercussão na Kiev ocupada. 0 jogo ficou conhecido como a partida da morte, pois alguns relatos posteriores davam conta de que todos os jogadores do time ucraniano foram executados após a vitória. No entanto, segundo Moretti (2018), isso não passou de uma lenda urbana, em que pese o fato de que semanas depois do jogo vários atletas foram presos e enviados para o campo de concentração de Siretz, onde quase todos morreram. De qualquer forma, a partida entrou para o imaginário popular como um ato de resistência frente a violenta ocupação nazista, bem como um símbolo de heroísmo dos jogadores, que mesmo sob ameaças reais, não desistiram da vitória. ${ }^{55}$

Em 1966 a Argentina foi escolhida para ser a sede da 11a Copa do Mundo, que seria realizada em 1978. No entanto, em 1976 foi instaurada uma Ditadura militar que vigoraria até 1983. Segundo Ribeiro (2013), o ditador, General Vilela via na realização dos jogos uma oportunidade política, um distração e disfarce para a repressão e violência sistematicamente empreendida contra opositores. Diante dessa realidade, Ribeiro (2013) destaca que grupos de esquerda, com a ajuda da França e dos meios de comunicação organizaram

\footnotetext{
55 Para saber mais: DOUGAN, Andy. Futebol \& Guerra: resistência, triunfo e tragédia do Dínamo na Kiev ocupada pelos nazistas. Trad. Maria Inês Duque Estrada. Rio de Janeiro: Jorge Zahar Ed., 2004.
} 


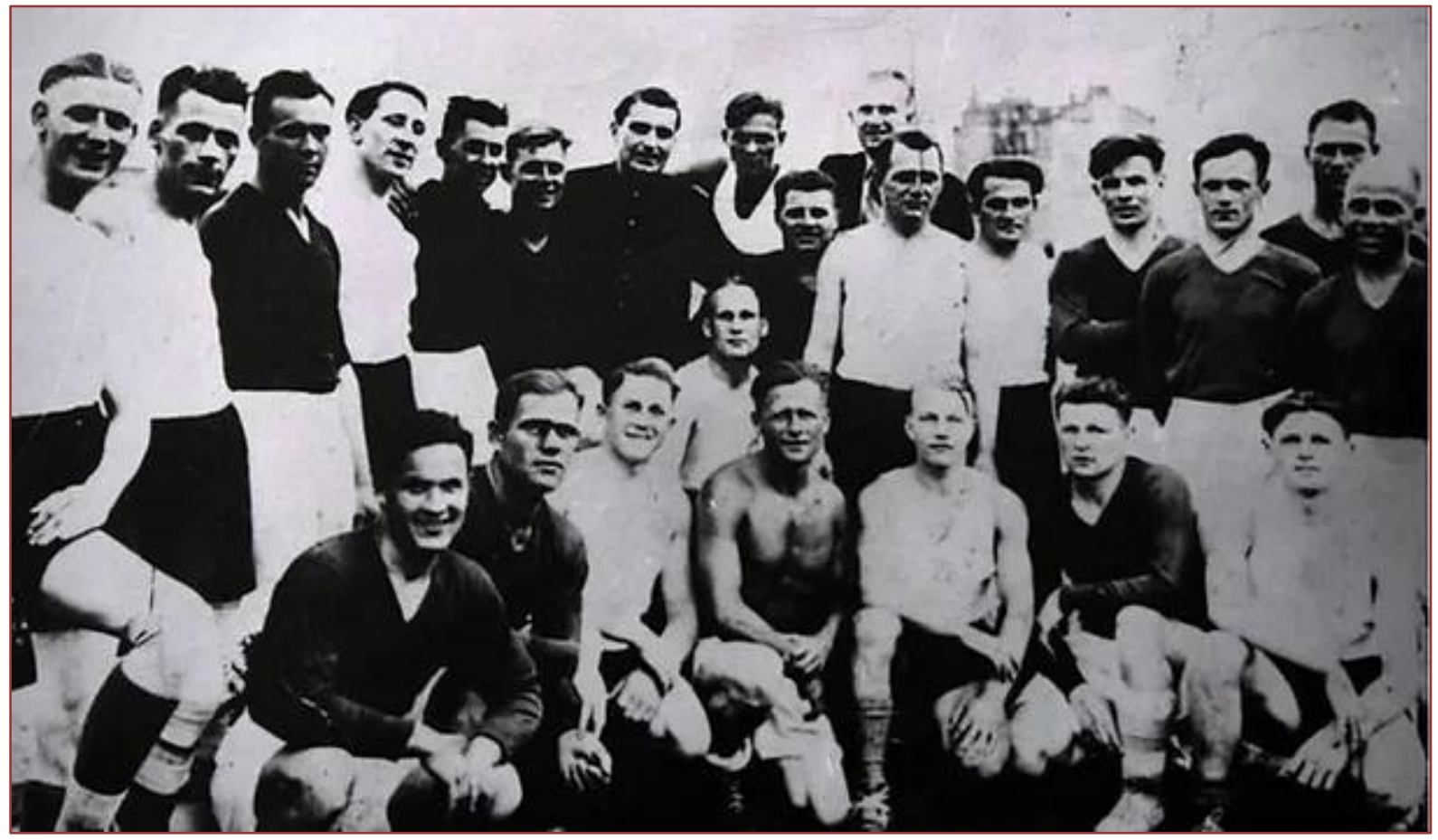

Imagem 2: Time da partida da morte

Fonte: Reprodução BBC News In: <https://www.megacurioso.com.br/copa-do-mundo-2014/42833-partida-damorte-saiba-o-que-ocorreu-com-o-time-que-desafiou-os-nazistas.htm>

um comitê para boicotar a realização da Copa com a criação, em 1977, do COBA (C.O.B.A. - Collectif pour le boycott de l'organisation par l'Argentine de la coupe de monde de football). Ainda segundo o autor as atividades do comitê foram diversas "desde publicações de manifestos, envio de carta a autoridades francesas (na sua maioria solicitando a adesão ao boicote) e a realização de manifestações de rua, como por exemplo, diversas ações de abaixo-assinado em apoio ao boicote em frente a embaixada argentina, em Paris." (RIBEIRO, 2013, p.4). Apesar do grande números de adeptos e dos esforços do COBA, a copa se realizou e foi largamente utilizada como elemento de propaganda pelo governo Videla.

\section{CONCLUSÕES}

O futebol sempre acompanhou a vida humana e suas emoções nas mais variadas formas, experimento e vivenciando a dor e a alegria, a esperança e a frustração, a vida e a morte nas mais variadas sociedades. Sobretudo no Ocidente, influencia e transforma lares e realidades, principalmente nos lugares mais precários e carentes. Neste artigo, ressaltamos sua presença em três fatos históricos que, infelizmente, deixaram tristes cicatrizes. Mas de fato, a inegável forma com que os torcedores acompanham seus clubes de coração não mudou, visto que esse sentimento de difícil definição entre os torcedores ultrapassaram todas e quaisquer manobras políticas, e o espírito esportivo tendeu a reinar nesta curta trajetória do futebol na história da humanidade, com grandes exemplos, como os apontados dentro das Guerras, como em outros nem tão grandes, mas que marcaram várias gerações e se perpetuam, tornando-se algo além do palpável e visível. Assim como Sevcenko diz em seu artigo "Futebol, metrópoles e desatinos (1994)": 


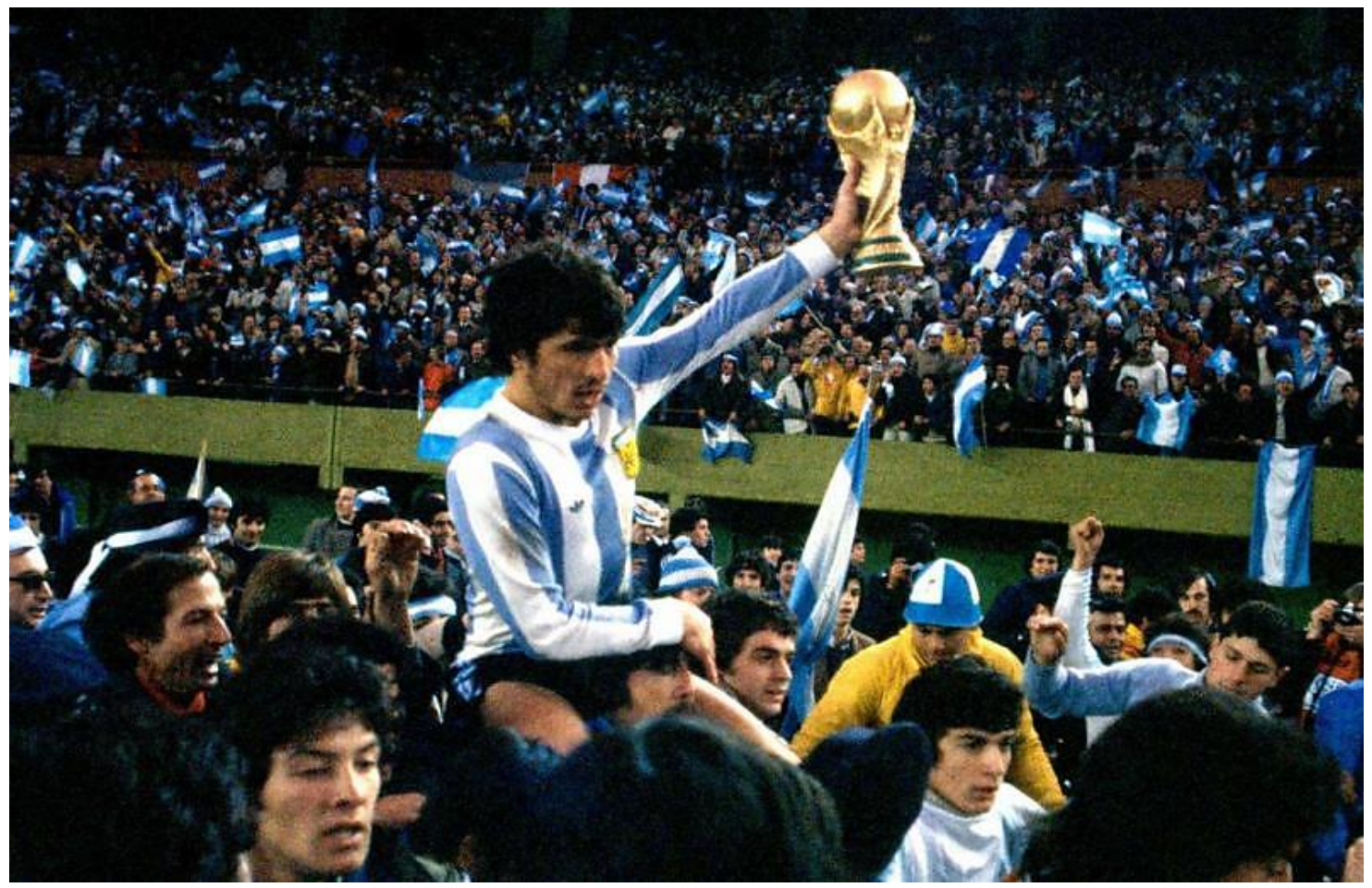

Imagem 3: Vitória da Seleção Argentina mesmo com a tentativa de boicote.

Disponível em: <https://the18.com/soccer-entertainment/lists/world-cup-champions-lifting-trophy

A maior imponderabilidade do futebol, que como vimos é típica e lhe dá uma dimensão imprevisível emocionante, faz com que aumente também o significado e o efeito que a participação das torcidas tem sobre o resultado das partidas". (SEVCENKO, 1994. p.36).

\section{REFERÊNCIAS}

[1] CAFÉ Lucas Santos. Futebol, Poder e Política. Anais do I Encontro de História do CAHL Centro de Artes, Humanidades e Letras. UFRB. Cachoeira-BA, 2010. Disponível em: <http://www3.ufrb.edu.br/lehrb/wpcontent/uploads/2011/08/LucasCaf\%C3\%A9.pdf>. Acesso em: 07 ago. 2019.

[2] HOLLANDA, Bernardo Buarque de. Futebol, ciência e cultura. Cienc. Cult., São Paulo , v. 66, n. 2, p. 24-26, June 2014. Disponível em: <http://cienciaecultura.bvs.br/scielo.php?script=sci_arttext\&pid=S0009$67252014000200011 \& \operatorname{lng}=$ en\&nrm=iso $>$. Acesso em 10.Set. 2019.

[3] MORRETI, Fernanado. Nazistas vs Ucranianos: o jogo da morte. Aventuras na História, 2018. Disponível em:

[4] https://aventurasnahistoria.uol.com.br/noticias/reportagem/nazistas-vs-ucranianos-o-jogo-damorte.phtml Acesso. 10.ago.2019

[5] PINTO, Tales dos Santos. Uma trégua de natal na I Guerra Mundial. Brasil Escola. Disponível em: <https://brasilescola.uol.com.br/historiag/uma-tregua-natal-na-i-guerra-mundial.htm> Acesso em: 18.jun.2019.

[6] RIBEIRO, Luiz Carlos, Futebol e ditadura na América Latina: a experiência do C.O.B.A. Anais XXVII Simpósio Nacional de História. $\quad$ Natal/RN, $2013 . \quad$ Disponível em: <http://www.snh2013.anpuh.org/resources/anais/27/1364915151_ARQUIVO_FuteboleditaduranaAmericaLatina,Ri beiro_1_.pdf. Acesso em: 18 jun. 2019.

[7] SEVCENKO, Nicolau. Futebol, poder e política. Revista USP. Dossiê Futebol, São Paulo, 1994. pp.30-37. Disponível em: <http://www.revistas.usp.br/revusp/article/view/26956/2873>. Acesso em: 07.ago. 2019. 


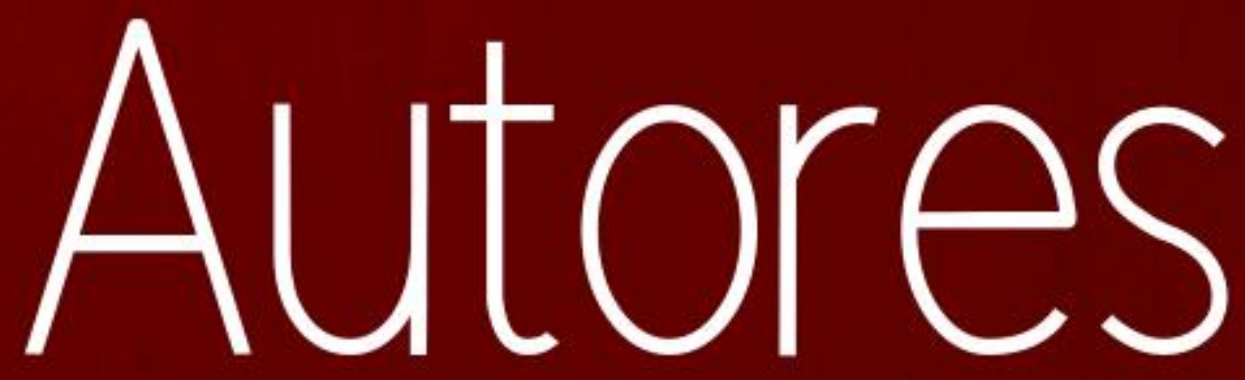




\section{AMANDA PEREIRA RISSO SAAD}

Possui graduação em Psicologia (Universidade Católica Dom Bosco - 2008), Pós-Graduação em Psicoterapia de Orientação Psicanalítica (Universidade Católica Dom Bosco - 2009), Mestrado pelo Programa de Pós-Graduação Stricto Sensu em Saúde e Desenvolvimento na Região Centro-Oeste (Universidade Federal de Mato Grosso do Sul - 2016), Pós-Graduação Lato Sensu em Mídias na Educação (Universidade Federal de Mato Grosso do Sul - 2019). Aluna regular de Doutorado no Programa de Pós-Graduação Stricto Sensu em Saúde e Desenvolvimento na Região Centro-Oeste, linha de pesquisa: Atenção à saúde integral da criança, do adolescente e da gestante (Universidade Federal de Mato Grosso do Sul - 2019 / 2022). Atua nos seguintes temas: Avaliação Psicológica, Psicoterapia para crianças e adolescentes, Psicoeducação, Processos Grupais (crianças, adolescentes e famílias), Psicopatologia da infância e adolescência, Desenvolvimento Psicossocial de crianças e adolescentes neurotípicos e com deficiência e Repercussões da deficiência no contexto familiar e educacional. Consultora Ad Hoc (referee) do Periódico Revista Eletrônica Saúde Mental, Álcool e Drogas (SMAD), editado pela Escola de Enfermagem de Ribeirão Preto da Universidade de São Paulo.

\section{ANDREA NÁRRIMAN CEZNE}

Professora Adjunta da Universidade Federal de Santa Maria (UFSM). Doutora em Direito pela Universidade Federal do Rio Grande do Sul (UFRGS).

\section{ANDRES JUAN PABLO SILVA SANCHEZ}

Bacharel em Direito pela Universidade do Estado do Amazonas - UEA

\section{ANTÔNIO HENRIQUE QUEIROZ CONCEIÇÃO}

Bacharel em Administração pela Universidade Federal do Amazonas - UFAM com Doutorado em Engenharia de Produção, concentração em Redes de Empresas e Planejamento da Produção pela Universidade Paulista - UNIP. Professor da Faculdade de Estudos Sociais - FES na cidade de Manaus - Amazonas. Atuação nos seguintes temas: Administração, Engenharia de Produção, Desenvolvimento Regional, Empreendedorismo, Cooperativismo, Turismo, Construção Civil e Agricultura Familiar

\section{ANTÔNIO VAGNER ALMEIDA OLAVO}

Professor do Instituto de Natureza e Cultura da Universidade Federal do Amazonas. Pesquisador na área de inovação, empreendedorismo, accountability e gestão pública.

\section{BEATRIZ NAEMI GENOVEZ AOKI}

Atualmente é Professora de Língua Portuguesa do Fundamental II na EMEF Maria Guilhermina de Castro em Cariacica - ES e autora de material didático ligado às habilidades socioemocionais. Fez Administração na UNICAMP (Faculdade de Ciências Aplicadas) e Complementação Pedagógica de Licenciatura em Letras. Está cursando o MBA de Gestão de Pessoas da USP (Esalq). Concluiu o Programa de Desenvolvimento de Liderança na Educação da ONG Ensina Brasil. Participou do Projeto Valores da Amazônia, experiência imersiva em uma aldeia indígena no Acre pela SOS Amazônia, a fim de impulsionar o voluntariado como meio de exercício da solidariedade e cidadania. Ser parte da transformação enquanto indivíduo e sociedade é seu propósito de vida.

\section{BEATRIZ ROSÁLIA GOMES XAVIER FLANDOLI}

Psicóloga, Mestra e Doutora em Educação (UFMS/CCHS), professora adjunta da UFMS/Campus do Pantanal (CPAN), atuando no curso de Psicologia e no Mestrado em Educação Social PPGE/CPAN/UFMS. Coordenadora do Grupo de Estudos e Pesquisas sobre Cultura, Psicologia, Educação e Trabalho, em que pesquisa: 1. As determinações culturais da consciência e 2 . Sociedade, violência e sistema punitivo. 


\section{BONIEK PEREIRA DA SILVA}

Advogado, graduado pelo Centro Universitário Luterano de Manaus - CEULM/ULBRA (2010). Pósgraduado em Direito Constitucional pela AVM - Faculdade Integrada (2014). Pós-graduando em Direito Tributário na Faculdade Única de Ipatinga - FUNIP. Pós-graduando em Direito Previdenciário e Direito do Consumidor na Faculdade LEGALE. Atuou como Auditor Interno na Universidade Federal do Amazonas - UFAM. Atualmente atua como Advogado no Banco da Amazônia - BASA. Tem experiência nas áreas de direito Cível, Consumidor, Família, Juizado Especial e Constitucional.

\section{CAMILA FENALTI SALLA}

Advogada com ênfase nas áreas Tributária e Empresarial. Professora na Fundação Escola Superior da Defensoria Pública do Estado do Rio Grande do Sul (FESDEP). Pós-Graduada em Direito Constitucional. Pós-Graduada em Direito Civil. Pós-Graduação em Direito Empresarial pela Fundação Getúlio Vargas (FGV) em andamento.

\section{CHRISTIANO FRANÇA DA CUNHA}

Professor de Marketing na Universidade Estadual de Campinas (UNICAMP). Membro associado do Centro de Estudos Organizacionais da Universidade de São Paulo (CORS/USP). Pós doutor pelo Institut National de la Recherche Agronomique (INRA)/AgroParisTech, em Paris/França. Doutor em Administração (FEA/USP), Mestre em Economia Aplicada (ESALQ/USP) e Graduação em Engenharia Agronômica (ESALQ/USP).

\section{DAVID DE BRITO ALVARENGA}

Natural de Inconfidentes, licenciando no curso de Licenciatura em História no IFSULDEMINAS Campus Inconfidentes desde 2019.

\section{ESTEFANO BATISTA SILVA}

Tecnólogo em Finanças pela FGV - EAESP, MBA em Finanças, Controladoria e Auditoria pela FGV EBAPE e Mestre em Administração pela Universidade Salvador UNFACS.

\section{GEISA ALESSANDRA CAVALCANTE DE SOUZA}

Servidora Pública da Universidade Federal de Mato Grosso do Sul - UFMS, desde 2003. Possui graduação em Serviço Social pela Universidade para o Desenvolvimento do Estado e da Região do Pantanal - UNIDERP (2011), mestrado em Saúde da Família pela Universidade Federal de Mato Grosso do Sul - UFMS (2016), área de concentração em Avaliação de Tecnologias, Políticas e Ações em Saúde. Tem experiência na área de Cuidado à Saúde do Adulto. Orientou trabalho de conclusão de curso na área de Enfermagem, com ênfase em Bioética e Saúde do Trabalhador, nos anos de 2014 e 2017, na Faculdade de Mato Grosso do Sul - FACSUL. Atuou como professora formadora no curso de "Prevenção do uso de álcool e drogas para educadores de escolas públicas", na UFMS (2015). Colaborou com o desenvolvimento e aprimoramento das ações do Projeto Saúde e Prevenção nas Escolas- SPE, realizadas em escolas do município de Campo Grande- MS, em parceria com a UFMS, em 2016. Desenvolveu atividades como facilitadora no curso de Aperfeiçoamento em Preceptoria, oferecido pelo Hospital Universitário HUMAP- UFMS em 2017. Neste mesmo ano, participou como membro avaliador de trabalhos no "Simpósio Multiprofissional- a interdisciplinaridade nas linhas de cuidado", realizado na UFMS. Em 2019, avaliou trabalhos no eixo INTEGRA, do evento da Sociedade Brasileira para o Progresso da Ciência (SBPC-edição 71), sediado na UFMS, no Congresso Internacional de Direitos Humanos, sediado na Universidade Católica Dom Bosco- UCDB, bem como projetos no Programa Centelha de Mato Grosso do Sul. Palestrante no XXI Congresso de Cardiologia de Mato Grosso do Sul e participante no I Congresso de Saúde e Desenvolvimento na Região Centro- Oeste. Presidente do Colegiado da Unidade de Produção de Cirurgias do HUMAP, na perspectiva da integração profissional, melhoria 
dos processos de trabalho e qualidade do cuidado em saúde ao paciente cirúrgico. Doutoranda no Programa de Pós Graduação Stricto Senso em Saúde e Desenvolvimento na Região Centro

\section{IZABELLA PATRÍCIA BRITO DA SILVA}

Possui graduação em Serviço Social pela Universidade do Estado do Rio Grande do Norte (2010). Pós-graduação em Políticas Públicas da Assistência Social pela Faculdade Católica Nossa Senhora das Vitórias (2016). E mestrado em Serviço Social e Direitos Sociais pela UERN (2019). Atua como docente na Faculdade do Complexo Educacional Santo André. E como assistente social no Centro de Referência Especializado de Assistência Social. Tem experiência na área de Serviço Social, com ênfase em políticas sociais e infância e juventude. Integrante do Grupo de Estudo e Pesquisa em Políticas Públicas (GEPP/UERN).

\section{JEAN CARLOS RIBEIRO DE LIMA}

Mestre em Ciências Sociais e Humanidades pela Universidade Estadual de Goias - Câmpus UNUCSEH - Anápolis - Programa de Mestrado em Território e Expressões Culturais do Cerrado (TECCER). Foi bolsista da Fundação de Amparo à Pesquisa do Estado de Goiás (FAPEG). Possui Especialização em História pela Universidade Estadual de Goiás - Câmpus Itapuranga. Graduado em História pela Universidade Estadual de Goiás - Câmpus Itapuranga. É professor do Colégio Alvaro de Melo (Ceres, GO). É professor na Educação de Jovens e Adultos (EJA) - Heitoraí-GO.

\section{JOÃO PAULO FERREIRA}

Natural de Bueno Brandão, é licenciando em História no IFSULDEMINAS - Campus Inconfidentes desde 2019, tendo como foco em suas pesquisas e escritos, a história do futebol.

\section{MÁRCIA DA SILVA PEREIRA CASTRO}

Professora Adjunta do curso de Graduação em Serviço Social e do Programa de Pós-graduação em Serviço Social e Direitos Sociais (PPGSSDS) da Universidade do Estado do Rio Grande do Norte (UERN). Graduada em Serviço Social (1990) e Especialista em Antropologia (1998) pela Universidade do Estado do Rio Grande do Norte-UERN. Mestre (2009) e doutora (2014) em Ciências Sociais pela Universidade Federal do Rio Grande do Norte-UFRN. Atualmente, Diretora da Faculdade de Serviço Social (FASSO), membro do Comitê Institucional de Pesquisa e Inovação (CIPI) e do Conselho Municipal de Assistência Social (CMAS) de Mossoró-RN. Desenvolve atividades docentes na área de Serviço Social, com ênfase em Fundamentos Históricos Teóricometodológicos do Serviço Social, desenvolvendo, também, atividades de pesquisa e extensão com os seguintes temas: atuação profissional em Serviço Social, implementação e avaliação de Políticas Sociais, com destaque para a Política de Assistência Social e para as políticas pertinentes à área da criança e do adolescente. Integrante dos seguintes grupos de pesquisa: Grupo Interdisciplinar de Estudo e Avaliação em Políticas Públicas (GIAPP/UFRN) e Grupo de Estudo e Pesquisa em Políticas Públicas (GEPP/UERN). Tem orientado monografias e dissertações com temas referentes à política de assistência social, bem como foi supervisora de uma docente no Programa Nacional de PósDoutorado (PNPD) junto ao PPGSSDS.

\section{MARCOS JOEL DE MELO SANTOS}

Mestre em Psicologia e psicólogo pela Universidade Federal da Bahia (UFBA); Graduado e Especialista em Relações Públicas pela Universidade do Estado da Bahia (UNEB); Bacharel em Direito pela Universidade Católica de Pernambuco (UNICAP); Membro da Comissão Regional de Direitos Humanos da PRF em Roraima.

\section{MARIANA FENALTI SALLA}

Defensora Pública do Estado do Rio Grande do Sul. Pós-Graduação Lato Sensu em Direito Civil. PósGraduação Lato Sensu em Direito Constitucional. 


\section{MARY ANNE VIEIRA SILVA}

Pós-Doutora em Geografia pela Universidade Federal de Juiz de Fora (UFJF) (2019). Doutora em Geografia pela Universidade Federal de Goiás (UFG) (2013). Mestre em Geografia pela Universidade de São Paulo (USP) (2001). Graduada em Geografia pela Universidade Federal do Ceará (UFC) (1994). Professora Estatutária Adjunto Nível II da Universidade Estadual de Goiás (UEG) em regime de dedicação em tempo integral à docência e à pesquisa (RTIDP). Coordenadora do Centro Interdisciplinar de Estudos África-Américas (CieAA). Professora do Programa de Pósgraduação Stricto Sensu, nível mestrado, em Territórios e Expressões Culturais no Cerrado (TECCER) e do curso de Geografia do Campus Anápolis de Ciências Socioeconômicas e Humanas (CCSEH) da Universidade Estadual de Goiás (UEG). Desenvolve pesquisas no âmbito da Geografia Cultural numa perspectiva pós colonial, tendo como principais temáticas: religiões de matriz africana (candomblé), relações étnico-raciais, processos diaspóricos, territorialidades e poder.

\section{MICHELINE MEDEIROS DOS SANTOS SANT'ANNA}

Relações Públicas (UNICAP), Pedagoga (UFMS-CPAN), Especialista em Docência para a Educação Profissional, Científica e Tecnológica (IFMS), Mestra em Educação (PPGE-UFMS-CPAN). Membro do Grupo de Estudos e Pesquisas sobre Infância e Educação Infantil no período de 2014-2017; Membro do Grupo de Estudos e Pesquisas sobre Cultura, Psicologia, Educação e Trabalho (Pesquisas sobre: As determinações culturais da consciência / Sociedade, violência e sistema punitivo).

\section{MONIK PEREIRA DA SILVA}

Graduada em Engenharia Ambiental pelo Centro Universitário Luterano de Manaus CEULM/ULBRA (2010). Especializada em Engenharia de Segurança do Trabalho pela Universidade do Estado do Amazonas - UEA (2012). Atualmente atua como Especialista em Engenharia Ambiental na Secretaria Municipal de Saúde de Manaus - SEMSA. Tem experiência na área de Supervisão, gestão, administração, orientação, emissão de pareceres e laudos técnicos de serviços de engenharia ambiental e de segurança do trabalho.

\section{PAULO ROBERTO HAIDAMUS DE OLIVEIRA BASTOS}

Possui graduação em Farmácia Bioquímica pela Universidade Federal de Mato Grosso do Sul (1980), Mestrado em Educação pela Pontifícia Universidade Católica de São Paulo (PUC-SP) (1997), e Doutorado em Educação pela Pontifícia Universidade Católica de São Paulo (PUC-SP) (1999). Professor Titular (Full Professor) da Universidade Federal de Mato Grosso do Sul (UFMS) (2017). Professor Visitante (Visiting Researcher) e pesquisador permanente do Programa de PósGraduação Stricto Sensu em Saúde e Desenvolvimento na Região Centro-Oeste (PPGSD), da Faculdade de Medicina (FAMED), da Universidade Federal de Mato Grosso do Sul (UFMS) - Áreas de Concentração: Saúde e Sociedade. Linhas de pesquisa: 1. Atenção à saúde integral da criança, do adolescente e da gestante; 2 . Doenças emergentes, reemergentes e negligenciadas na Região Centro-Oeste: aspectos sócio-culturais ecoambientais, epidemiológicos e clínicos, e 3. Avaliação de tecnologias, políticas e ações em saúde. Revisor (Referee) de periódicos científicos. Atua nas áreas de ensino, extensão e pesquisa em Saúde, Bioética, Biodireito, Ética Científica e Espiritualidade e Ciência, com ênfase na interdisciplinaridade da investigação qualitativa.

\section{RODOLFO APARECIDO LEITE}

Cursando $5^{\circ}$ período da graduação de Direito na Faculdade de Direito da UNIVAP. Pretendo me aprofundar na área do Direito, fazendo um mestrado logo após finalizar a graduação, seguir carreira pública mas não me decidi ainda, interesse na área penal, tanto que já estou dissertando um artigo com tema da área. 


\section{SAMUEL DE GOIS VIDA}

Graduando da primeira turma de Licenciatura em História, no IFSULDEMINAS - Campus Inconfidentes. Participou como bolsista do Pro-BID (2019 - 2020) e, atualmente, faz parte do Projeto de Iniciação Científica (2020) "A formação da elite militar brasileira: a Escola de EstadoMaior do Exército e seus regulamentos de ensino (1935 - 1955)" e do PIBID (2020 - 2021). Por fim, ademais, estuda proficiência das línguas estrangeiras inglês e francês.

\section{SUSANE PATRÍCIA MELO DE LIMA}

Professora Assistente da Universidade do Estado do Amazonas/UEA no Curso de Geografia/ENS. Doutoranda em Geografia vinculada ao Programa de Pós-Graduação em Geografia da Universidade Federal do Amazonas/UFAM/PPGEOG, na linha de pesquisa: Espaço, Território e Cultura na Amazônia. Geógrafa, bacharel e licenciada, formada pela Universidade Federal do Amazonas/UFAM; Mestre em Geografia formada pelo Programa de Pós-Graduação em Geografia da Universidade Federal do Amazonas; Atua nas Ciências Humanas, com ênfase em Sociedade, Cultura, Natureza e Ambiente, Geografia Humana - Geografia Urbana e Econômica, Política e Teoria da Geografia, com ênfase nos temas: Cidades, Rede Urbana, Regiões Metropolitanas na Amazônia, Configurações Produtivas, Desenvolvimento Regional, processos de metropolização no Amazonas e metropolização do espaço, dinâmicas do trabalho na RMM. Pesquisadora do Núcleo de Pesquisas Urbana e Regional/Npur/UEA. Pesquisadora do Grupo de Pesquisa Geografia Regional e Produção do Espaço/UNIFESSPA.

\section{VITOR AUGUSTO DE CARVALHO LINS}

Sou estudante de Direito, atualmente cursando o 5o período na Univap - Universidade do Vale do Paraíba, além disto possuo graduação em Engenharia Elétrica. Possuo alto interesse na área jurídica, sobretudo em temas como Teoria Geral do Estado, Direito Constitucional, Direito do Trabalho e Direito Previdenciário. Pretendo fazer mestrado ou pós-graduação em algumas dessas áreas após a minha graduação. Possuo Inglês Fluente e Italiano Básico, além de ser atualmente estagiário da Defensoria Pública da União (DPU).

\section{ZENILDA BATISTA BRUGINSKI}

Professora do Curso de Serviço Social da Universidade Estadual de Ponta Grossa - Paraná. Graduação Faculdade de Serviço Social PUC-PR . Mestre em Serviço Social pela PUC-RJ. Doutorado na PUC-SP. DOUTORANDA EM Psicologia Social na Universidad Kennedy-Argentina. 


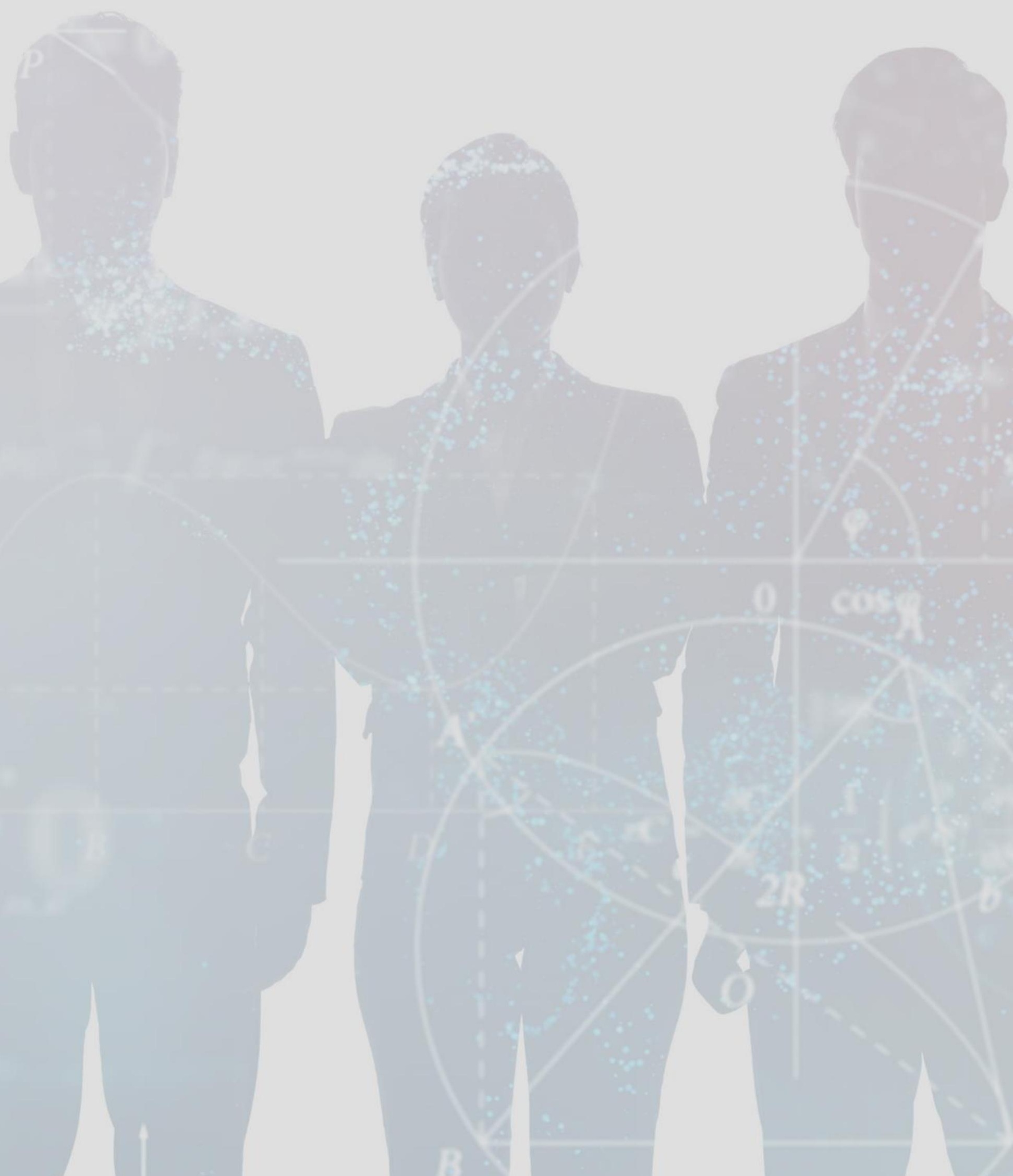

